
of Engineers ${ }_{\circledast}$

Engineer Research and

Development Center

\title{
Landscape Management Plan for the United States Merchant Marine Academy, NY
}

Megan W. Tooker and Adam D. Smith

February 2018

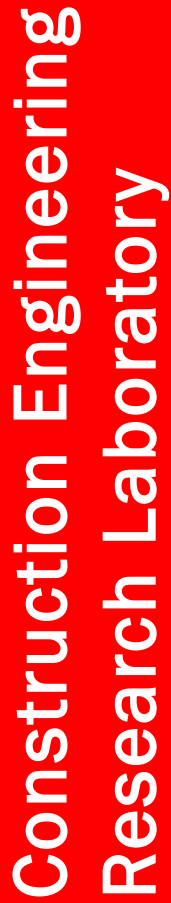

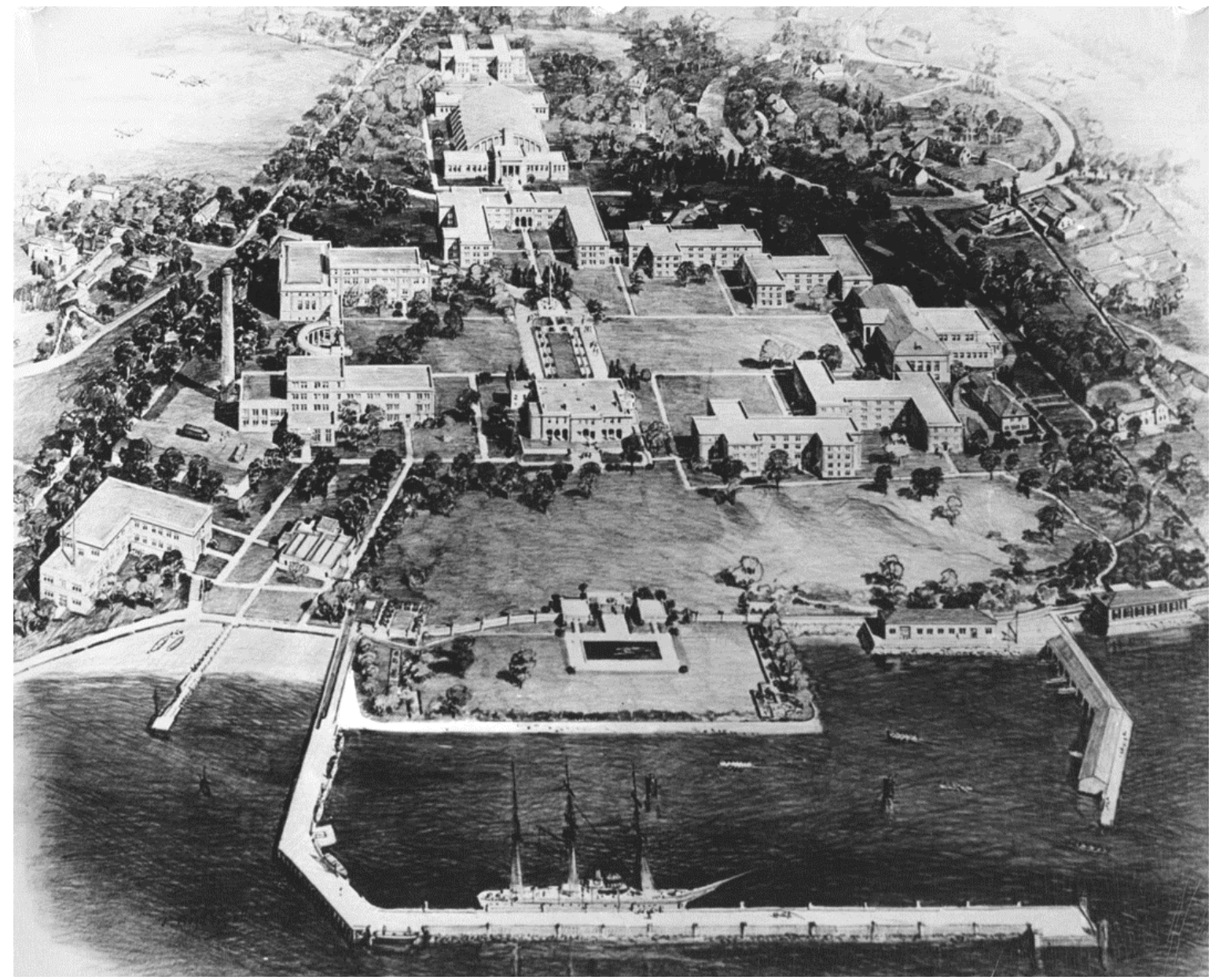


The U.S. Army Engineer Research and Development Center (ERDC) solves the nation's toughest engineering and environmental challenges. ERDC develops innovative solutions in civil and military engineering, geospatial sciences, water resources, and environmental sciences for the Army, the Department of Defense, civilian agencies, and our nation's public good. Find out more at www.erdc.usace.army.mil.

To search for other technical reports published by ERDC, visit the ERDC online library at http://acwc.sdp.sirsi.net/client/default.

Cover Photo: Rendering of the USMMA by Alfred Hopkins \& Associates Architects, undated (USMMA Bland Library). 


\section{Landscape Management Plan for the United States Merchant Marine Academy, NY}

Megan W. Tooker and Adam D. Smith

Construction Engineering Research Laboratory

U.S. Army Engineer Research and Development Center

2902 Newmark Drive

PO Box 9005

Champaign, IL 61826-9005

Final report

Approved for public release; distribution is unlimited.

Prepared for U.S. Department of Transportation, Maritime Administration

MAR-612-W23-495

1200 New Jersey Ave SE

Washington, DC 20590

Under Project Number 450153, “USMMA Landscape Management Plan” 


\section{Abstract}

The U.S. Merchant Marine Academy (USMMA) is located in Kings Point, New York. The Academy is listed on the National Register of Historic Places (\#14000538). The Historic District contains contributing mansions constructed during the Gold Coast Era and Academy buildings constructed from 1942 to 1969. This report identifies several historic component landscapes within USMMA, and makes recommendations for their maintenance and preservation.

This report establishes landscape guidelines to aid USMMA in preservation of the Historic District. This management plan inventories the existing cultural landscape at the USMMA, and it includes recommendations for managing the historic landscape in the future. The contributing landscapes are identified in the study, and their existing conditions discussed. Treatment recommendations for preserving and rehabilitating the landscapes are provided. This document meets the requirements for federal agencies to address their cultural resources which are defined as any prehistoric or historic district, site, building, structure, or object. Especially relevant is Section 110 of the National Historic Preservation Act, which requires federal agencies to inventory and evaluate their cultural resources.

DISCLAIMER: The contents of this report are not to be used for advertising, publication, or promotional purposes. Citation of trade names does not constitute an official endorsement or approval of the use of such commercial products. All product names and trademarks cited are the property of their respective owners. The findings of this report are not to be construed as an official Department of the Army position unless so designated by other authorized documents. 


\section{Contents}

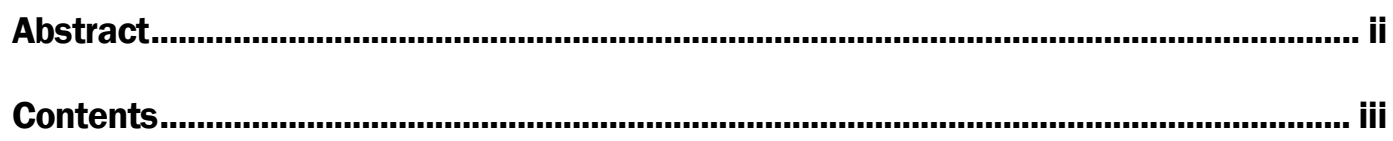

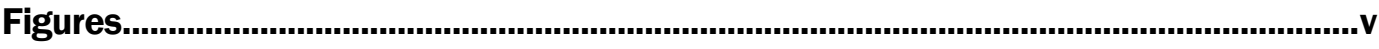

Preface ............................................................................................................. xi

Unit Conversion Factors................................................................................................... xii

Abbreviations................................................................................................. xifi

1 Methodology ................................................................................................................ 1

1.1 Background ....................................................................................

1.2 Objective.........................................................................................

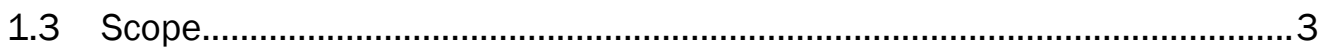

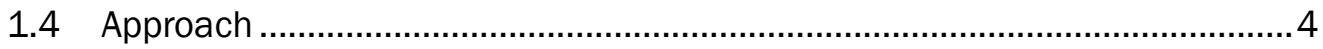

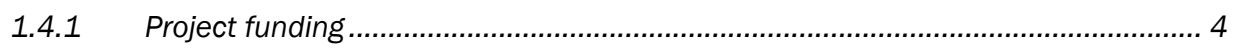

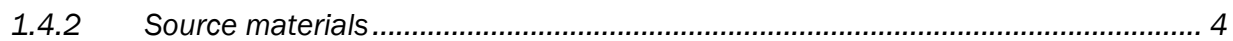

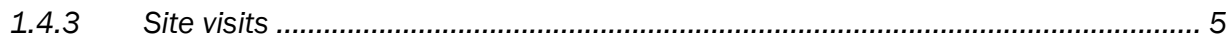

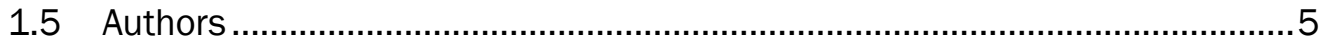

2 Landscape Inventory........................................................................................... 7

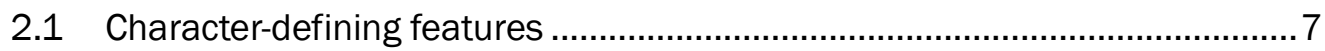

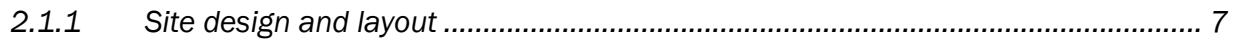

2.1.2 Topography and natural features................................................................... 9

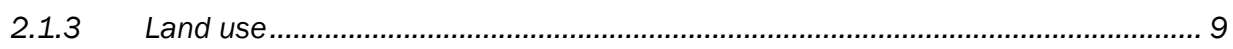

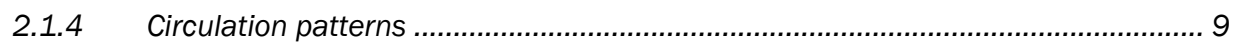

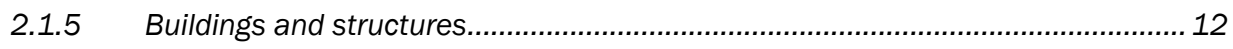

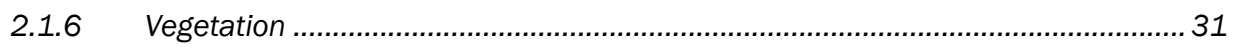

2.1.7 Small-scale features ..................................................................................... 53

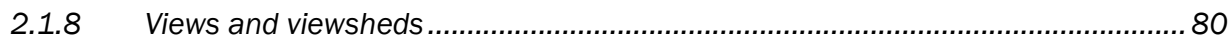

3 Recommended Landscape Management Practices ...............................................99

3.1 Preserving historic character and character-defining features ................. 99

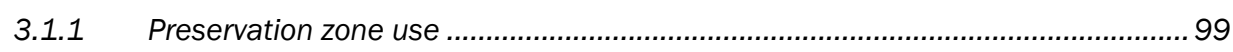

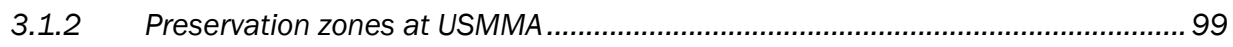

3.1.3 Circulation patterns .................................................................................. 101

3.1.4 In-kind replacement ............................................................................. 101

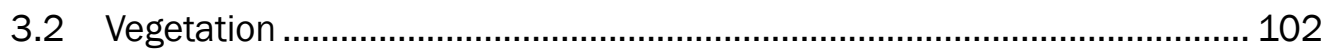

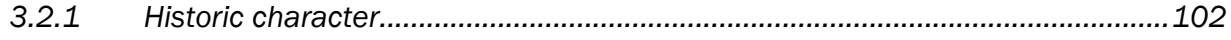

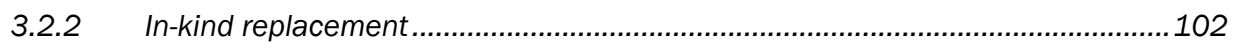

3.2.3 Sustainability........................................................................................ 103

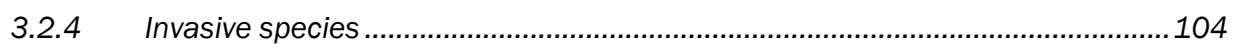

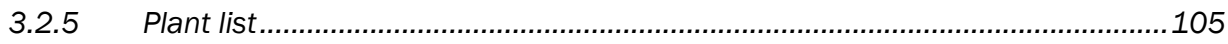




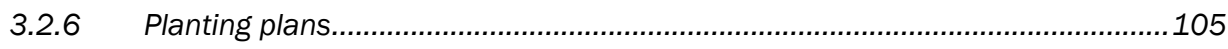

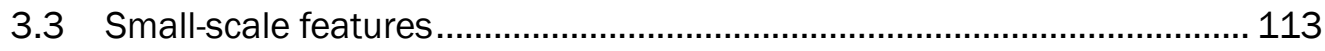

3.3.1 Monuments and memorials ............................................................................ 113

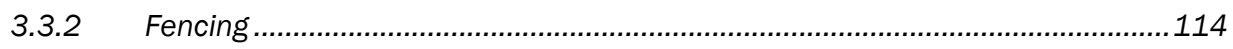

3.3.3 Lighting and site furnishings ....................................................................... 115

4 Conclusion .............................................................................................................. 117

References................................................................................................................. 119

Appendix A: Plant List ................................................................................. 121

Appendix B: Historic Landscape Development .......................................................... 123

Report Documentation Page 


\section{Figures}

Figure 1. Map of Long Island with US Merchant Marine Academy marked in red (Google.com)

Figure 2. Location and boundary for the USMMA Historic District, as shown by heavy black outline (U.S. Geological Survey [USGS]).

Figure 3. Diagram showing the axial layout of the Academy buildings to the Chrysler mansion (now Wiley Hall), which is shown just left of center (ERDCCERL).

Figure 4. Diagram showing roads (green) from before the Academy, and the location of Academy gates (blue) and Academy roads, roadways, and sidewalks (black).

Figure 5. Flagstone walkway, as it was new in 1942 (USMMA Bland Library).

Figure 6. Newly completed asphalt drive to Wiley Hall, 1942 (USMMA Bland Library). Photo also shows existing granite stone lining the drive.

Figure 7. Neiley house (Quarters A) in 1915, with floor plan superimposed at bottom of the photo (from "House" 1915).

Figure 8. The Neiley house garage (Quarters J), south facade (ERDC-CERL, 2013).

Figure 9. West facade of Grenwolde Casino (now Quarters D) (USMMA 2013).................15

Figure 10. Photograph of front facade of Meighan house (Melville Hall), 1965 (USMAA Library).

Figure 11. View to the south of Meighan house garage (Quarters K) (ERDC-CERL, 2013).

Figure 12. North facade of Schenck House (Land Hall), 1942 (NARA).

Figure 13. Barstow mansion and drive (ERDC-CERL, 2013).

Figure 14. Real estate brochure for Chrysler estate, 1941 (American Merchant Marine Museum).

Figure 15. One of the two guard rooms forming the Vickery Gate, the main

entrance to USMMA (ERDC-CERL, 2015)...

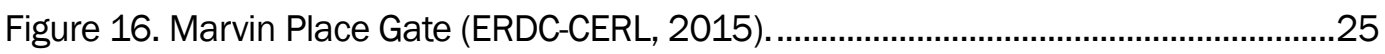

Figure 17. Mallory Pier (ERDC-CERL, 2015)...................................................................26

Figure 18. Crowninshield Boat Shed (ERDC-CERL, 2013)...............................................2

Figure 19. Swimming race in pool on Dedication Day, 1943 (USMMA Bland Library). .28

Figure 20. View of Eldridge pool (ERDC-CERL, 2012).....................................................28

Figure 21. Marshall Pool newly enclosed, 1943 (USMMA Bland Library). .........................29

Figure 22. Interior of Marshall Pool, 1943 (USMMA Bland Library)..................................30

Figure 23. Marshall Pool is now Prosser Boat House (ERDC-CERL, 2013).........................30

Figure 24. View from Bland Library of grove of trees in quadrangle (ERDC-CERL, 2015).

Figure 25. View of formal plantings around Wiley Hall (ERDC-CERL, 2015). ......................32

Figure 26. View of plantings in front of Delano Hall (ERDC-CERL, 2015). 
Figure 27. Alfred Hopkins \& Associates Architects rendering of the USMMA, undated (USMMA Bland Library). Note location of trees in quadrangle.

Figure 28. Aerial photograph of Academy showing mature trees in quadrangle remaining from Bendel/Chrysler estate, 1943 (USMMA Bland Library).

Figure 29. During the construction of Bowditch Hall, 1942 (USMMA Bland Library). Note protective fencing around mature trees to prevent damage during construction.

Figure 30. Rows of trees along walkways to Wiley Hall (ERDC-CERL, 2015).

Figure 31. Rows of trees in quadrangle along paths to Delano Hall (ERDC-CERL, 2015)

Figure 32. New flower beds adjacent to Delano Hall drill space in quadrangle (ERDC-CERL, 2015).

Figure 33. Rear of Wiley Hall, 1942 (USMMA Bland Library) .37

Figure 34. Vegetation at rear of Wiley Hall (ERDC-CERL, 2015). 38

Figure 35. Plantings along terraces behind Wiley Hall (ERDC-CERL, 2015).

Figure 36. Vegetation surrounding bathhouse by pool, 1943 (USMMA Bland Library). 39

Figure 37. Vegetation surrounding bathhouse by pool (ERDC-CERL, 2015).

Figure 38. Formal shrubs surround the WWII Memorial and Bell (ERDC-CERL, 2015).

Figure 39. Pergola covered in wisteria vines (ERDC-CERL, 2015)....................................40

Figure 40. Entrance and drive to Neiley house, 1943 (USMMA Bland Library)..................41

Figure 41. Entrance to Quarters A (Neiley house) (ERDC-CERL, 2015).

Figure 42. Formal garden (center foreground) located behind hospital, 1943 (USMMA Bland Library).

Figure 43. Formal garden located behind the hospital, as seen in yearbook photograph, 1944 (USMMA Bland Library)

Figure 44. Garden behind Patten Medical Clinic (ERDC-CERL, 2015).

Figure 45. Aerial showing Barstow gardens (center) with the mansion (lower left), 1943 (USMMA Bland Library). [Note that the formal garden at the top right was part of the Schebera gardens.].

Figure 46. Aerial view of the Barstow gardens (center), 1943 (USMMA Bland Library). The Schebera Estate along Steamboat Road is visible near bottom far right of photograph, along with its associated formal gardens.

Figure 47. Remnants of Barstow Estate formal gardens, with gun monument in rear (ERDC-CERL, 2015).

Figure 48. Barstow rock garden/folly (ERDC-CERL, 2015).

Figure 49. Real estate sales brochure for Barstow estate showing heavy foundation plantings around mansion, c. 1960 (Morgan Guarantee Trust).

Figure 50. Vegetation around foundation of Barstow mansion (currently the American Merchant Marine Museum; ERDC-CERL, 2013).

Figure 51. View looking north at former Houston house and garden, with Chrysler rose garden at lower right (house and garden later demolished), undated (Mackay et al. 1970). 
Figure 52. Schenck house (Land Hall), north facade, 1942 (NARA)................................49

Figure 53. Schenck house (Land Hall), north facade (ERDC-CERL, 2015). ........................50

Figure 54. Front facade of Meighan house, date unknown (USMMA Bland Library).........51

Figure 55. Rear of Meighan house, 1965 (USMMA Bland Library)...................................51

Figure 56. Front facade of Meighan house, after replacement of foundation plantings, 1967 (USMMA Bland Library).

Figure 57. Foundation plantings along front facade of Melville Hall (ERDC-CERL, 2015).

Figure 58. Amphitrite pool, 1942 (USMMA Bland Library).

Figure 59. Amphitrite Pool with the flagpole behind (ERDC-CERL, 2015).

Figure 60. The USS Missouri monument and the view north to Truxton Arcade that connects Jones (left) and Barry (right) Halls (ERDC-CERL, 2015).

Figure 61. Monument honoring Vice Admiral Richard McNulty (foreground) is located between flagpole and Powell Oval (with deck gun in photo's center) (ERDC-CERL, 2015).

Figure 62. James Harvey Tomb monument (foreground) in line with Kings Point

Bell, sundial, deck gun, and flagpole in background (ERDC-CERL, 2015).

Figure 63. Sundial and 5-inch deck gun in Powell Oval (ERDC-CERL, 2015)....

Figure 64. Training gun placement with flagstone paving being laid adjacent to flagpole, 1942 (USMMA Bland Library). Note CCC buildings in background.

Flagpole was moved in 1943 to its current location.

Figure 65. One of the urns on the terraces at the rear of Wiley Hall (ERDC-CERL, 2015).

Figure 66. WWII monument and bell (ERDC-CERL, 2015).

Figure 67. One of the Kings Point Eagles located in front of O'Hara Hall (ERDC-

CERL, 2015).

Figure 68. The Mariner Monument is located by the Vickery Gate entrance to USMMA (ERDC-CERL, 2015).

Figure 69. Monument to Ricardo and Rita Alvarado, with plaque added on existing boat mooring in 2001 (ERDC-CERL, 2015).

Figure 70. Memorial to those who perished on 9 March 1945, with plaque added on an existing boat mooring (ERDC-CERL, 2015).

Figure 71. Marker placed on an existing mooring in 1980 to thank Mr. and Mrs J.

Seward Johnson for the research vessel Mazurka (ERDC-CERL, 2015).

Figure 72. Ackerman Anchor, in recognition of James H. Ackerman in 1988, is located adjacent to Vickery Gate (ERDC-CERL, 2015).

Figure 73. Krinsky Circle monument, given for RADM Paul L. Krinsky, in front of Melville Hall (ERDC-CERL, 2015).

Figure 74. Propeller in front of Yocum Sailing Center (ERDC-CERL, 2015)

Figure 75. The Bjornson Anchor, a memorial for Lars Cameron Bjornson, located in front of the chapel (ERDC-CERL).

Figure 76. Unmarked anchor in front of gate to Barstow Mansion (now the American Merchant Marine Museum) (ERDC-CERL, 2015). 
Figure 77. WWII troopship propeller, adjacent to Barstow Mansion (now the American Merchant Marine Museum; ERDC-CERL, 2015).

Figure 78. Gun memorial, dedicated to the U.S.N. Armed Guard of World War II and U.S. Liberty vessel SS J. Pinckney Henderson at site of former Barstow estate's gardens (ERDC-CERL, 2015).

Figure 79. Bench from Class of 1996 in memory of Brian Thomas Patrick Roche, located in front of the Chapel (ERDC-CERL, 2015).

Figure 80. Class of 1942 memorial bench is located between Chapel and Wiley Hall (ERDC-CERL, 2015).

Figure 81. World Trade Center Memorial located near the Chapel (ERDC-CERL, 2015).

Figure 82. Iris garden in memory of Doris $\mathrm{H}$. Sherman is located adjacent to the Chrysler mansion pergola (ERDC-CERL, 2015).

Figure 83. Scott Michael Heilman, Jr. memorial lookout is adjacent to Melville Hall (ERDC-CERL, 2015).

Figure 84. Memorial bench for Aaron N. Seesan, Class of 2003, in front of Land

Hall (ERDC-CERL, 2015).

Figure 85. Bench given by Class of 1956 in memory of deceased class members in rear of Wiley Hall (ERDC-CERL, 2015).

Figure 86. Bench for Class of 1962, presented in 1993 and located in rear of Wiley Hall (ERDC-CERL 2015). 72

Figure 87. Bench by waterfront and Eldridge Pool (ERDC-CERL, 2015)..............................73

Figure 88. Bench by Vickery Gate (ERDC-CERL, 2015) ..................................................... 74

Figure 89. Bench by Melville Hall (ERDC-CERL, 2015)..................................................... 74

Figure 90. Picnic tables by Land Hall (ERDC-CERL, 2015)................................................75

Figure 91. Bollards by Wiley Hall (ERDC-CERL, 2015)...................................................... 75

Figure 92. Bollards by flagpole (ERDC-CERL, 2015).......................................................76

Figure 93. Trash receptacle by Delano Hall (ERDC-CERL, 2015).......................................... 76

Figure 94. Trash receptacle by Marvin Gate (ERDC-CERL, 2015)..................................... 77

Figure 95 Trash receptacles by Land Hall ERDC-CERL 2015)............................................. 77

Figure 96. Trash can style by Eldridge Pool (ERDC-CERL, 2015)........................................78

Figure 97. Smoking receptacle in front of Samuels Hall (ERDC-CERL, 2015).....................78

Figure 98. Planter by O'Hara Hall (ERDC-CERL, 2015). .................................................... 79

Figure 99. Planter by Furuseth Hall (ERDC-CERL, 2015). ...................................................79

Figure 100. View from Chrysler terrace in real estate advertisement, 1941

(American Merchant Marine Museum) ...................................................................................8

Figure 101. View from Wiley Hall to sound, 1943 (USMAA Bland Library)........................81

Figure 102. View from terraces of Wiley Hall to Long Island Sound (ERDC-CERL, 2015).

Figure 103. View to Chrysler mansion from water, 1941 (USMMA Bland Library).............82

Figure 104. View to Wiley Hall from waterfront, 1943, after Academy's

establishment (USMMA Bland Library).

Figure 105. View to Wiley Hall from waterfront (ERDC-CERL, 2015). 
Figure 106. View of Amphitrite Pool and Truxton Arcade, 1942 (USMMA Bland Library).

Figure 107. View of Amphitrite Pool and Truxton Arcade (ERDC-CERL, 2015).

Figure 108. View of Truxton Arcade from Amphitrite Pool, 1943 (USMMA Bland Library).

Figure 109. View of Truxton Arcade from Amphitrite Pool (ERDC-CERL, 2015)

Figure 110. View from Truxton Arcade toward flagpole and Wiley Hall, date unknown (USMMA Bland Library).

Figure 111. View from Truxton Arcade toward flagpole and Wiley Hall (ERDCCERL, 2013).

Figure 112. View through Truxton Arcade toward Amphitrite Pool, flagpole and Wiley Hall (ERDC-CERL, 2015).

Figure 113. View of front of Wiley Hall from Amphitrite Pool, 1942 (USMMA Bland Library). Note that the flagpole was moved in 1943 from here to its present location. 90

Figure 114. View of Wiley Hall from flagpole (ERDC-CERL, 2015).

Figure 115. View from library toward quadrangle, 1967 (USMMA Bland Library). ............92

Figure 116. View from library to quadrangle (ERDC-CERL, 2015)......................................92

Figure 117. View of Delano Hall from quadrangle, 1940s (USMMA Bland Library)..........93

Figure 118. View of Barney Square and Delano Hall (ERDC-CERL, 2015)........................93

Figure 119. View toward quadrangle from Delano Hall, 1947 (USMMA Bland Library).

Figure 120. View from Delano Hall toward quadrangle (ERDC-CERL, 2015).

Figure 121. Vickery Gate is the formal entrance to the Academy, and it is located along Steamboat Road (ERDC-CERL, 2015).

Figure 122. Entrance to Academy along Steamboat Road is just inside Vickery

Gate (ERDC-CERL, 2015). 96

Figure 123. View to water from Steamboat Road (ERDC-CERL, 2015). .96

Figure 124. View toward Vickery Gate from Steamboat Road (ERDC-CERL, 2015)...........97

Figure 125. View along Steamboat Road near American Merchant Marine Museum (ERDC-CERL, 2015).

Figure 126. Map of USMMA showing landscape preservation zones for treatment recommendations (ERDC-CERL).

Figure 127. Plantings at building entrances and corners of Jones and Barry Halls, 1943 (USMMA Bland Library) 106

Figure 128. Foundation plantings in front of Delano Hall, 1943 (USMMA Bland Library).

Figure 129. Preliminary design for Hospital Building showing plantings at entrances and corners, 1943 (USMMA).

Figure 130. Academy rendering by Alfred Hopkins and Associates, undated (USMMA Bland Library). 108

Figure 131. Foundation plantings in front of Fulton Hall, 1943 (USMMA Bland Library). 
Figure 132. Landscapes of Chrysler mansion (Wiley Hall), Houston Estate (demolished) and Schenck house (Land Hall), 1932 (USMMA Bland Library)................ 109

Figure 133. Photograph of foundation plantings around Schenck House (Land Hall), 1942 (USMMA Bland Library).

Figure 134. Planting plan for the front of Wiley Hall and the flagpole area (ERDC-

CERL, 2017.

Figure 135. Planting plan for rear of Wiley Hall (ERDC-CERL 2017).

Figure 136. Planting plan for the front of Melville Hall (ERDC-CERL, 2017).

Figure 137. New chain-link style of fencing material in quad area of the USMMA

Historic District (ERDC-CERL, 2017). 


\section{Preface}

This study was conducted for the U.S. Department of Transportation Maritime Administration under Project Number 450153, "U.S. Merchant Marine Academy Landscape Management Plan.” The technical monitor was Ms. Barbara Voulgaris, Federal Preservation Officer, U.S. Department of Transportation, Maritime Administration (MARAD).

The work was performed by the Land and Heritage Conservation Branch (CNC) of the Installations Division (CN), U.S. Army Engineer Research and Development Center - Construction Engineering Research Laboratory (ERDC-CERL). At the time of publication, Dr. Michael Hargrave was Chief, CEERD-CNC; and Mr. Donald K. Hicks was Acting Chief, CEERDCN. The Interim Deputy Director of ERDC-CERL was Ms. Michelle Hanson, and the Interim Director was Dr. Kirankumar Topudurti.

COL Bryan S. Green was the Commander of ERDC, and Dr. David W. Pittman was the Director. 


\section{Unit Conversion Factors}

\begin{tabular}{|l|c|l|}
\hline Multiply & \multicolumn{1}{|l|}{ By } & To Obtain \\
\hline acres & $4,046.873$ & square meters \\
\hline feet & 0.3048 & meters \\
\hline miles (U.S. statute) & $1,609.347$ & meters \\
\hline
\end{tabular}




\section{Abbreviations}

$\begin{array}{ll}\text { Term } & \text { Meaning } \\ \text { CCC } & \text { Civilian Conservation Corps } \\ \text { ERDC- } & \text { Engineer Research and Development Center - Construction } \\ \text { CERL } & \text { Engineering Research Laboratory } \\ \text { LIRR } & \text { Long Island Rail Road } \\ \text { MARAD } & \text { Maritime Administration } \\ \text { MARCOM } & \text { United States Maritime Commission } \\ \text { MIPR } & \text { Military Interdepartmental Purchase Request } \\ \text { NHPA } & \text { National Historic Preservation Act } \\ \text { NPS } & \text { National Park Service } \\ \text { NRHP } & \text { National Register of Historic Places } \\ \text { SHPO } & \text { State Historic Preservation Officer } \\ \text { USGS } & \text { U.S. Geological Survey } \\ \text { USMMA } & \text { United States Merchant Marine Academy } \\ \text { WWII } & \text { World War II }\end{array}$


(Intentionally blank.) 


\section{Methodology}

\subsection{Background}

Congress codified the National Historic Preservation Act of 1966 (NHPA), the nation's most effective cultural resources legislation to date, in order to provide guidelines and requirements for preserving tangible elements of our past. This was done primarily through the creation of the National Register of Historic Places (NRHP) in 1966. Contained within the NHPA (Sections 106 and 110) are requirements for federal agencies to address their cultural resources, which are defined as any prehistoric or historic district, site, building, structure, or object. Section 110 requires federal agencies to inventory and evaluate their cultural resources. Section 106 requires a determination of the effects of federal undertakings on properties deemed eligible or potentially eligible for the NRHP.

The United States Merchant Marine Academy (USMMA) Historic District is significant on a national level as the nation's only federally-owned educational facility for the advanced training of merchant mariners. It is also one of five federal service academies. ${ }^{1}$ The USMMA was established in 1942 with the acquisition of the Walter P. Chrysler estate at Kings Point, New York, and that first acquisition was quickly followed by adding other estates and grounds. Merchant Marine officers serve the U.S. merchant fleet including mostly commercial transport, with military transport as needed.

The architectural resources included in the USMMA Historic District were constructed specifically for or were converted for USMMA use during its initial establishment in 1942 and 1943. The converted resources were former Gold Coast estates which, although incorporated into the USMMA campus, retain their integrity and provide one of the few remaining spatial accounts of the extent and proximity of homes of the wealthy along Long Island's North Shore (Figure 1 and Figure 2). Collectively, the buildings within the USMMA Historic District provide academic, administrative, and residential support to cadet-midshipmen during their ashore training at USMMA. The USMMA Historic District, consisting of 39 contributing

\footnotetext{
1 Other federal service academies are U.S. Military Academy, U.S. Naval Academy, U.S. Air Force Academy, and U.S. Coast Guard Academy.
} 
resources and 10 noncontributing resources, meets National Register Criterion $\mathrm{C}$ as an excellent example of a significant concentration of buildings that are linked historically and that are physically and spatially interrelated. The centerpiece of the district is Wiley Hall, which was a preexisting mansion when the government purchased the property. The clockwise completion around Wiley Hall of Fulton, Bowditch, Barry, Jones, Cleveland, Rogers, Delano, Murphy, and Palmer Halls created a quadrangle (quad) that became the heart of the new Academy. The new buildings, all of which were completed between 1942 and 1944, were designed in a classically inspired vocabulary that echoed the Beaux Arts Classicism style of Wiley Hall, thus creating a unified architectural complex.

Figure 1. Map of Long Island with US Merchant Marine Academy marked in red (Google.com).

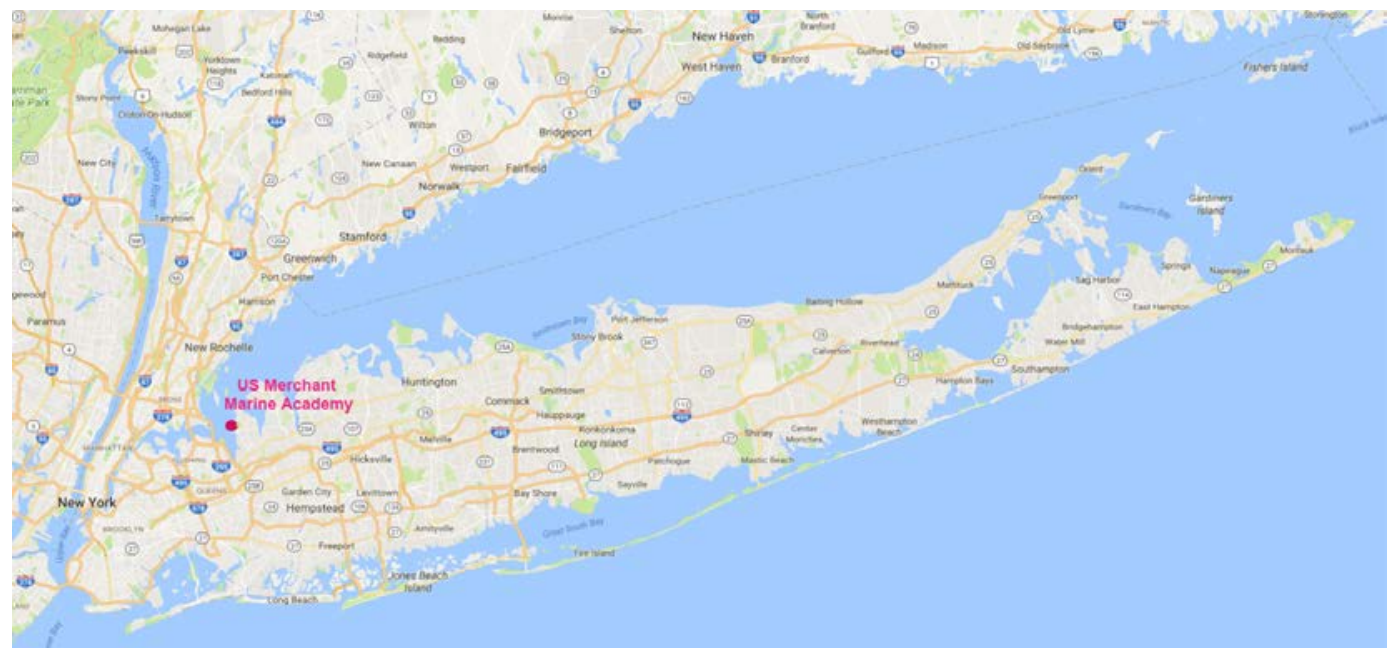


Figure 2. Location and boundary for the USMMA Historic District, as shown by heavy black outline (U.S. Geological Survey [USGS]).

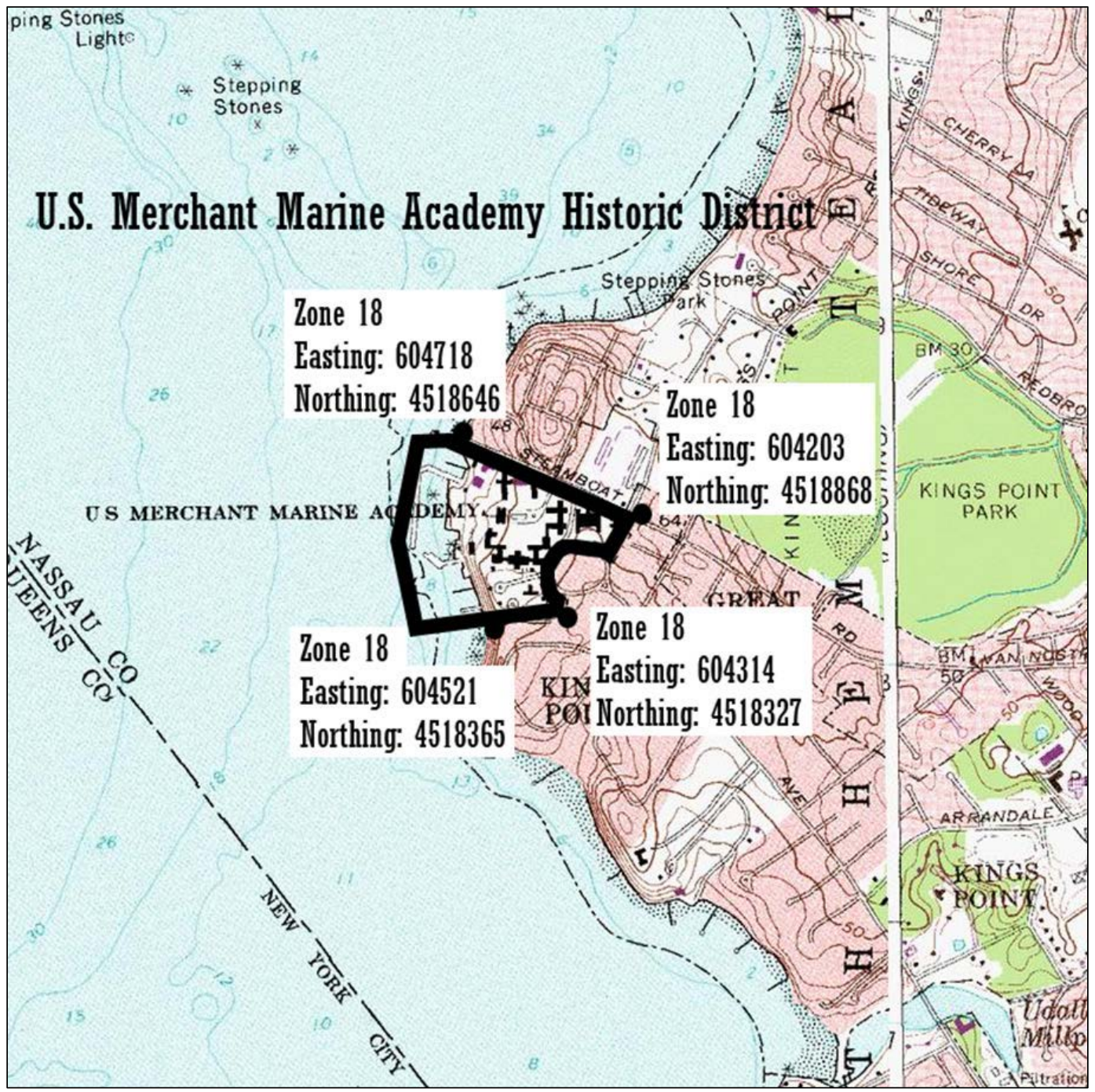

\subsection{Objective}

The project's objective was to develop a management plan for determining and preserving the significant historic landscapes within the USMMA Historic District.

\subsection{Scope}

First, an inventory of all landscapes and landscape features within the Historic District was completed. Second, these landscapes and features were evaluated according to the methods established in Guidelines for Identifying and Evaluating Historic Military Landscapes (Loechl et al. 2008), and their significance and integrity was determined. Photographic 
and historic documentation were then completed for any significant landscapes. Third, areas of preservation were identified and classified within preservation zones. Finally, general management recommendations were provided to help preserve and/or protect these resources in the future. These management recommendations include planting plans intended to help the USMMA preserve the landscape character in its historically significant areas by providing a list of appropriate and/or sustainable regional plant material (see Appendix A).

In addition, a landscape development history from a previous report (Smith et al. 2014b) was provided in Appendix B of this report as a reference for the significance of the USMMA historic landscape and for reference in consultation with the State Historic Preservation Officer (SHPO).

\subsection{Approach}

\subsubsection{Project funding}

Under a Military Interdepartmental Purchase Request (MIPR), the Engineer Research and Development Center-Construction Engineering Research Laboratory (ERDC-CERL) was retained by U.S. Department of Transportation, Maritime Administration (MARAD).

\subsubsection{Source materials}

The USMMA has performed four other architectural inventories and evaluations of buildings at the USMMA per Section 110 of the NHPA, as outlined below.

1. In 2005, the Louis Berger Group wrote a cultural resources survey report (Louis Berger 2005).

2. The second report was a character-defining features report for the USMMA written by ERDC-CERL (Smith et al. 2014a).

3. The third report expanded the boundaries of the Historic District in an NRHP nomination prepared by ERDC-CERL (Smith et al. 2014b). This work determined that the USMMA Historic District has two periods of significance: 1912-1941 (Gold Coast Era) and 1942-1969 (USMMA Design and Development). The 42-acre district consists of a contributing landscape and 38 contributing buildings, structures, and objects. The district is historically significant on a national level under 
National Register Criterion A as a reminder of the Golden Age period of the late nineteenth and early twentieth centuries. Criterion $\mathrm{C}$ is met through the design of the buildings that survive on the district's grounds (NPS 1991). The district was listed by the NRHP in August 2014 as \#14000538.

4. While the William Barstow Mansion is not a part of the USMMA Historic District, the fourth report was prepared by ERDC-CERL for the former Barstow property that is on the USMMA grounds and now serves as the American Merchant Marine Museum. This report summarized the mansion property's nomination and listing to the NRHP (Smith et al. 2014c). The William Barstow Mansion was listed on 29 August 2014 as NRHP \#14000539.

\subsubsection{Site visits}

The researchers conducted two site visits to inventory and assess buildings and structures at the USMMA. The site visits occurred in May 2015 and April 2017.

\subsection{Authors}

This project was conducted by a team of ERDC-CERL researchers from Champaign, Illinois. The authors were Megan Tooker (M. Landscape Arch) with 18 years of experience, and Adam Smith (M. Arch) with 18 years of experience. 
(Intentionally blank.) 


\section{Landscape Inventory}

\subsection{Character-defining features}

The National Park Service (NPS) defines historic character-defining features of a landscape as "prominent or distinctive aspects, qualities, or characteristics of a cultural landscape that contribute significantly to its physical character" (NPS 2000). Through the study of landscapes, the built environment is explained by the physical remains of the natural and cultural shaping forces. This section identifies the historically significant features and characteristics of the USMMA landscape.

To identify the prominent or distinctive characteristics that make a landscape historic, the physical features of the site are divided into eight areas: site and layout, land use, topography and natural features, circulation networks, buildings and structures, vegetation, small-scale features, and views and viewsheds. These landscape characteristics combine to form the built environment at USMMA.

\subsubsection{Site design and layout}

The strong axial layout of the house and gardens of the Bendel/Chrysler estate, credited to Charles W. Leavitt Jr., was continued in the design of the Academy. The academic buildings and residence halls were designed to ring a formal quadrangle with the Bendel/Chrysler mansion in the center. O'Hara Hall (the drill hall and gymnasium) was added east of the quadrangle and on axis with the entrance to Wiley Hall, the Powell Oval, the flagpole, the Amphitrite Pool, and the Truxton Arcade that joins Jones Hall and Barry Hall (Figure 3). A cross axis was created later with the addition of Bland Library in 1969, which is on a visual axis with Delano Hall and the formal plaza (Barney Square) in front of Delano Hall that was used for formations. The north-south paths and walkways between Bland Library and Delano Hall span the Powell Oval in front of Wiley Hall.

The careful layout of the walks along the axis and the preservation of the Powell Oval and Amphitrite Pool in front of the Bendel/Chrysler mansion were key to today's overall composition and design of the site. Wiley Hall holds a prominent location in the center of the quadrangle, creating a central element for campus design. 
Figure 3. Diagram showing the axial layout of the Academy buildings to the Chrysler mansion (now Wiley Hall), which is shown just left of center (ERDC-CERL).

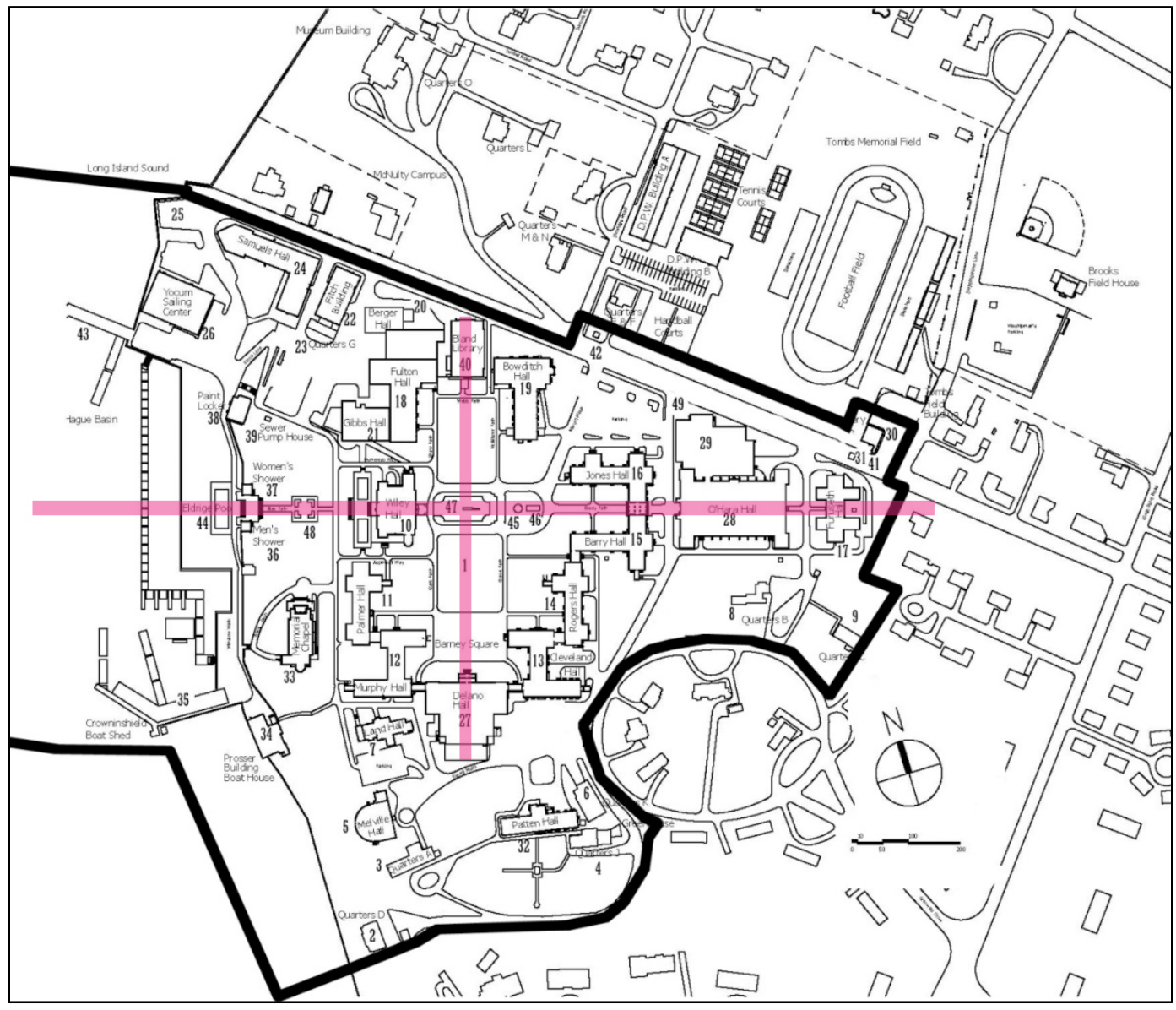

The athletic fields were built north across Steamboat Road from O'Hara Hall and the rest of the Academy. This area is not included in the USMMA Historic District, although it is visible from Vickery Gate and has been in use since 1942-first as a drill space, and then as athletic fields.

At the waterfront, a pier was added in 1943 to the existing Chrysler pier, to create Hague Basin and Mallory Pier. This addition allowed the training ships and vessels to be moored and protected. A second Gold Coast-era (Schenck) pier and the Crowninshield Boat Shed enclosed the southern end of Hague Basin. A large Colonial Revival chapel was added to the waterfront in 1962. Many upgrades have happened in the pier area to accommodate changing needs of vessels. The former public beach area was filled in during the 1960s, and it has been the site of the Yocum Sailing Center since 1994. 
The Barstow Estate was purchased in 1975 by the Alumni Association and transferred to the Academy in early 1979. A few private residences remain along Steamboat Road between the Barstow property and the Academy.

\subsubsection{Topography and natural features}

The USMMA is located on 81 acres that overlook the Long Island Sound, the Throgs Neck Bridge, and the boroughs of Bronx and Manhattan. The Academy's landscape gently slopes to the water's edge. The center of the Academy is dominated by Wiley Hall, originally the estate of Henri Bendel and then the Walter P. Chrysler family. The Academy's buildings envelop the historic Bendel/Chrysler mansion, to create a quadrangle in the center of the campus. The quadrangle is surrounded by quarters, with many of these buildings in existence before the Academy. The athletic fields are located north of the Academy's formal entrance at Vickery Gate. The waterfront landscape includes a series of paved and grass terraces descending from Wiley Hall to the water and including pergolas, retaining walls, a pool, and bathhouses. Docks, piers, and boathouses create a basin at the waterfront.

\subsubsection{Land use}

The USMMA Historic District encompasses a group of buildings of various property types (administrative, academic, residential, religious, and athletic/recreational). The Historic District forms a defined space in which the individual elements are similar in materials, architectural details, and physical proportions, and a space in which these elements collectively exhibit a unity of exterior design and create a cohesive visual environment. The USMMA has incorporated a series of preexisting Gold Coast-era mansions, houses, and support buildings to the south of the original Bendel/Chrysler estate. Their construction dates range from 1912 to the 1920 s.

\subsubsection{Circulation patterns}

The Academy's circulation pattern is shown in Figure 4. Vickery Gate is the main gate into the Academy. The gate is located on Steamboat Road, which preexisted the Academy and was named for the steamboat dock where the road meets the water's edge. Adjacent to the steamboat dock was the site of the Great Neck Park Recreation Area and bathhouse. Today the bathhouse is the site of U.S. Coast Guard Station Kings Point and 
Yocum Sailing Center. Third Street, which historically connected Steamboat Road with Grenwolde Drive, is gone. The street has been replaced by a drive (Farrell Road), which extends west from Steamboat Road, runs between O'Hara Hall and Jones Hall, and connects to Melville Hall. A smaller drive, Peabody Drive, extends from Farrell Road to Quarters A and D. Sunset Road, Elmridge Road, and Stepping Stone Lane still exist today; together they form the Academy's northern and eastern boundaries and provide access to the athletic fields and residences. The Marvin Place Gate's guard rooms still remain from 1943. Steamboat Road still serves as the entrance and backbone of the Academy today, although there are no remnants of Steamboat Pier and its associated landscape.

Figure 4. Diagram showing roads (green) from before the Academy, and the location of Academy gates (blue) and Academy roads, roadways, and sidewalks (black).

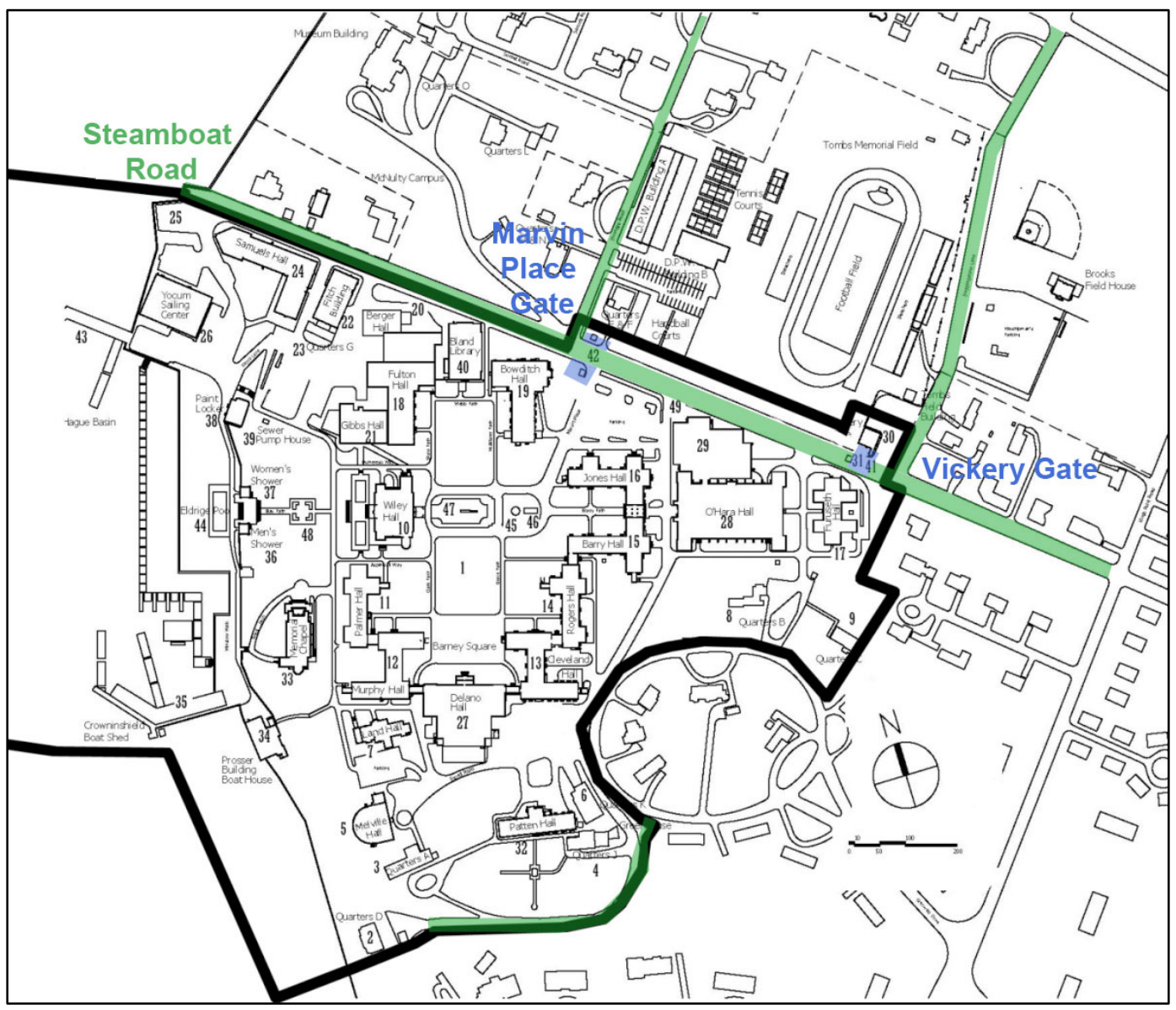

Paths and sidewalks around Wiley Hall are flagstone (Figure 5), while the paths around the Academy are concrete or asphalt, as required by vehicle traffic. The edges of the entrance drive to Wiley Hall are lined with granite, a feature assumed to remain from the Bendel/Chrysler ownership eras 
(Figure 6). Various new paving materials such as brick and red-colored pressed concrete are non-historic and recent additions to the landscape.

Figure 5. Flagstone walkway, as it was new in 1942 (USMMA Bland Library).

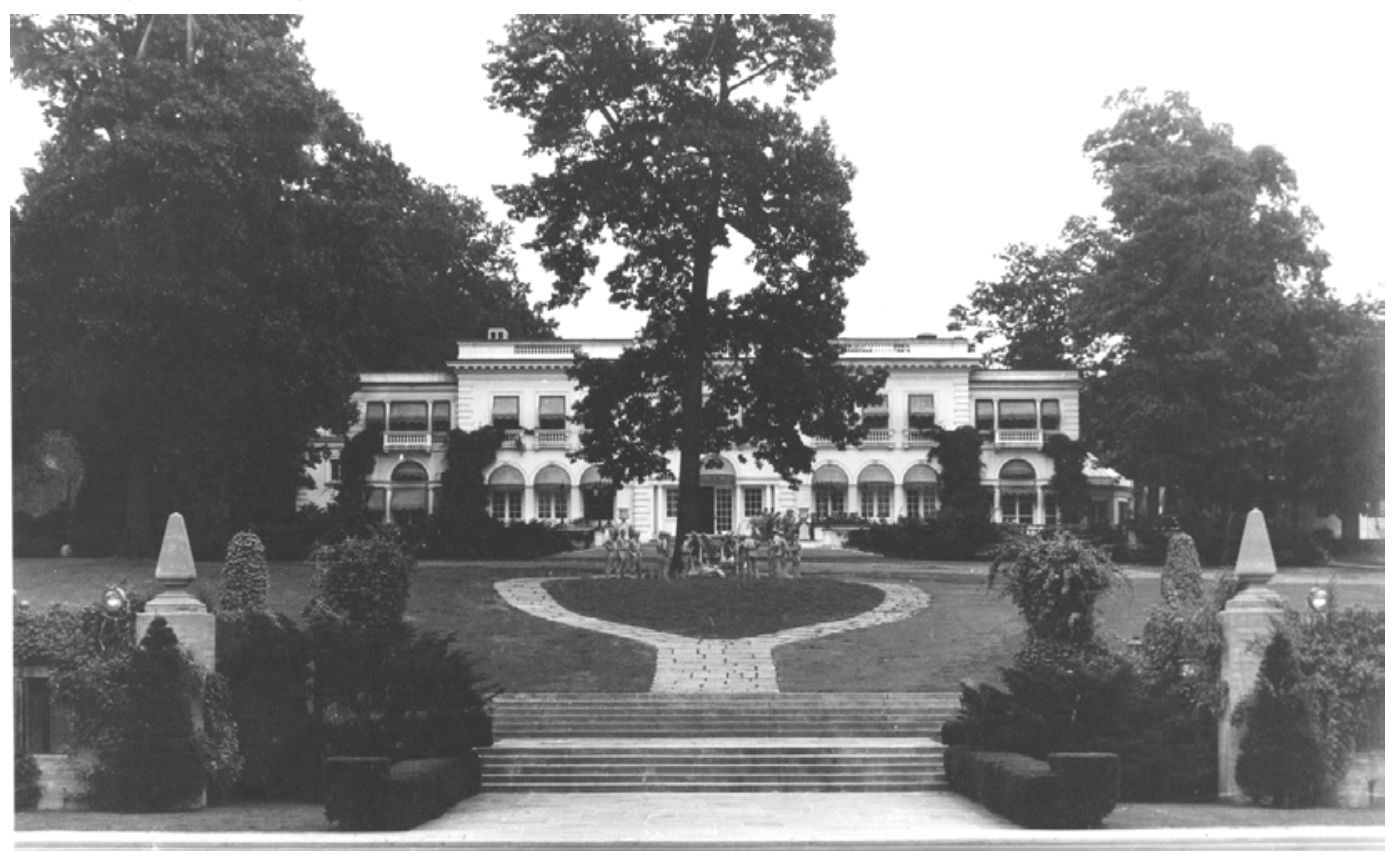

目

四

Figure 6. Newly completed asphalt drive to Wiley Hall, 1942 (USMMA Bland Library). Photo also shows existing granite stone lining the drive.

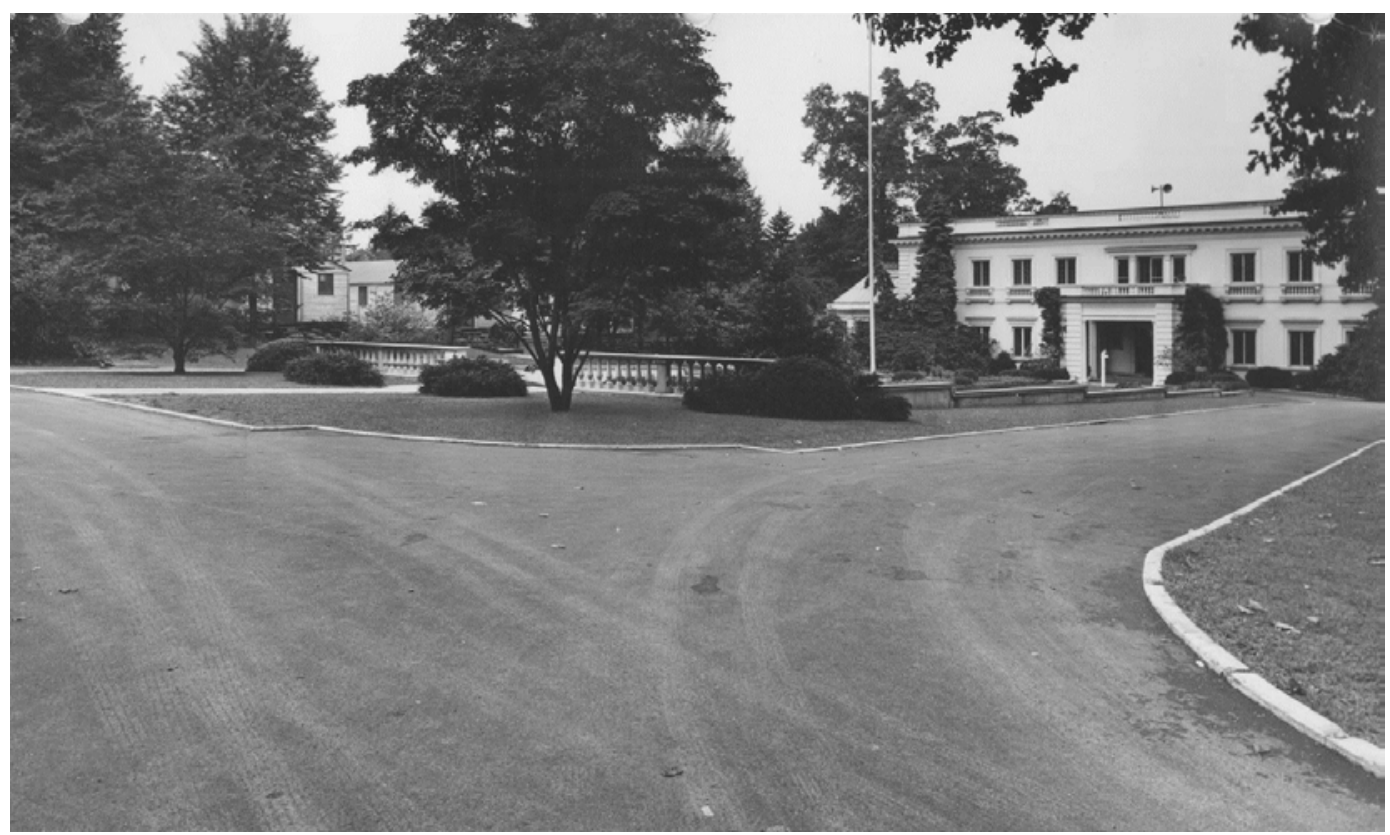




\subsubsection{Buildings and structures}

The buildings in the USMMA Historic District include remnants of the Gold Coast era including the Bendel/Chrysler mansion, Schenck Estate, Meighan Estate, Neiley Estate, an intact World War II (WWII) era "college" campus, and two Mid-Century Modern collegiate buildings (chapel and library). Collectively, these buildings illustrate a cohesive "college" campus and show the government's ability to adaptively reuse buildings for a war effort.

The Academy's Classical Revival-style buildings were designed with an emphasis on balance and symmetry. This cohesion and repetition of architectural elements was a conscious decision on the part of Alfred Hopkins \& Associates, who designed the buildings and gave the space a campus-like feeling. The centerpiece of the Historic District is Wiley Hall, the former Bendel-Chrysler mansion designed by New York-based architect Henry Otis Chapman Sr., which was located on property the government purchased in 1942. The clockwise completion of added residence halls and academic buildings around Wiley Hall created a quadrangle that became the heart of the new Academy. The new buildings, all of which were completed between 1942 and 1943, were designed in a Classical Revival-inspired vocabulary that echoed the Beaux Arts classical style of Wiley Hall, thus creating a unified architectural complex.

As a whole, the existing buildings in the USMMA Historic District retain a high degree of historic integrity. The Gold Coast estates incorporated into the USMMA campus retain their integrity and provide one of the few remaining spatial accounts of the extent and proximity of wealthy homes along Long Island's North Shore. The buildings designed and constructed for the USMMA campus in 1942 still exude their original Classical Revival style, and the addition of the Classical Revival-style chapel continued that theme into the $1960 \mathrm{~s}$.

\subsubsection{Gold Coast Quarters}

\subsection{Neiley house (Quarters A)}

Quarters A (Neiley house) was designed by Caretto \& Forster of New York and completed by 1915, at the latest, as part of the Grenwolde development (Figure 7). It is a large Dutch Colonial Revival-style house with a large ell to the north. It is one and a half stories tall, and the half story has almost 
full-width shed dormers. After the Academy's construction, the house was separated from the Grenwolde development by a fence.

Figure 7. Neiley house (Quarters A) in 1915, with floor plan superimposed at bottom of the photo (from “House" 1915).

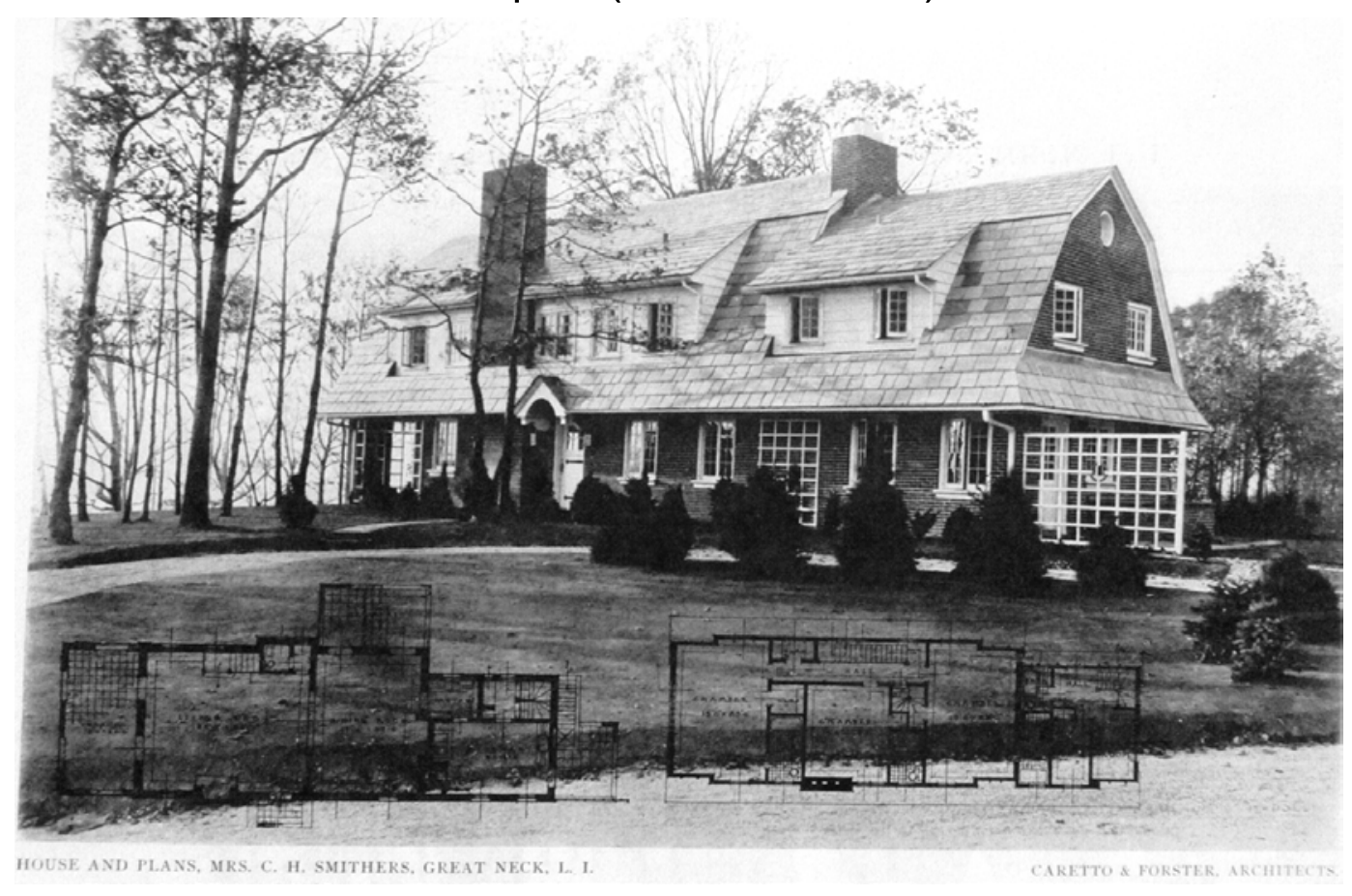

\subsection{Neiley house garage (Quarters $J$ )}

Quarters J was originally the garage and chauffeur's apartment (Figure 8) for the Neiley house (Quarters A). It is not known when the garage was constructed, but it was probably the same time as the house. The building is in the Dutch Colonial Revival style and is one and one-half stories in height, with large shed dormers on the north and south sides of the roof. There are one-story additions to the building on the east, west, and north sides. The building is constructed of brick, and the gambrel roof is covered in asphalt shingles. There is a large greenhouse attached to the house on the east side. The original garage is still used as a garage, but additions on either side now provide an entrance to the residence. 
Figure 8. The Neiley house garage (Quarters J), south facade (ERDC-CERL, 2013).

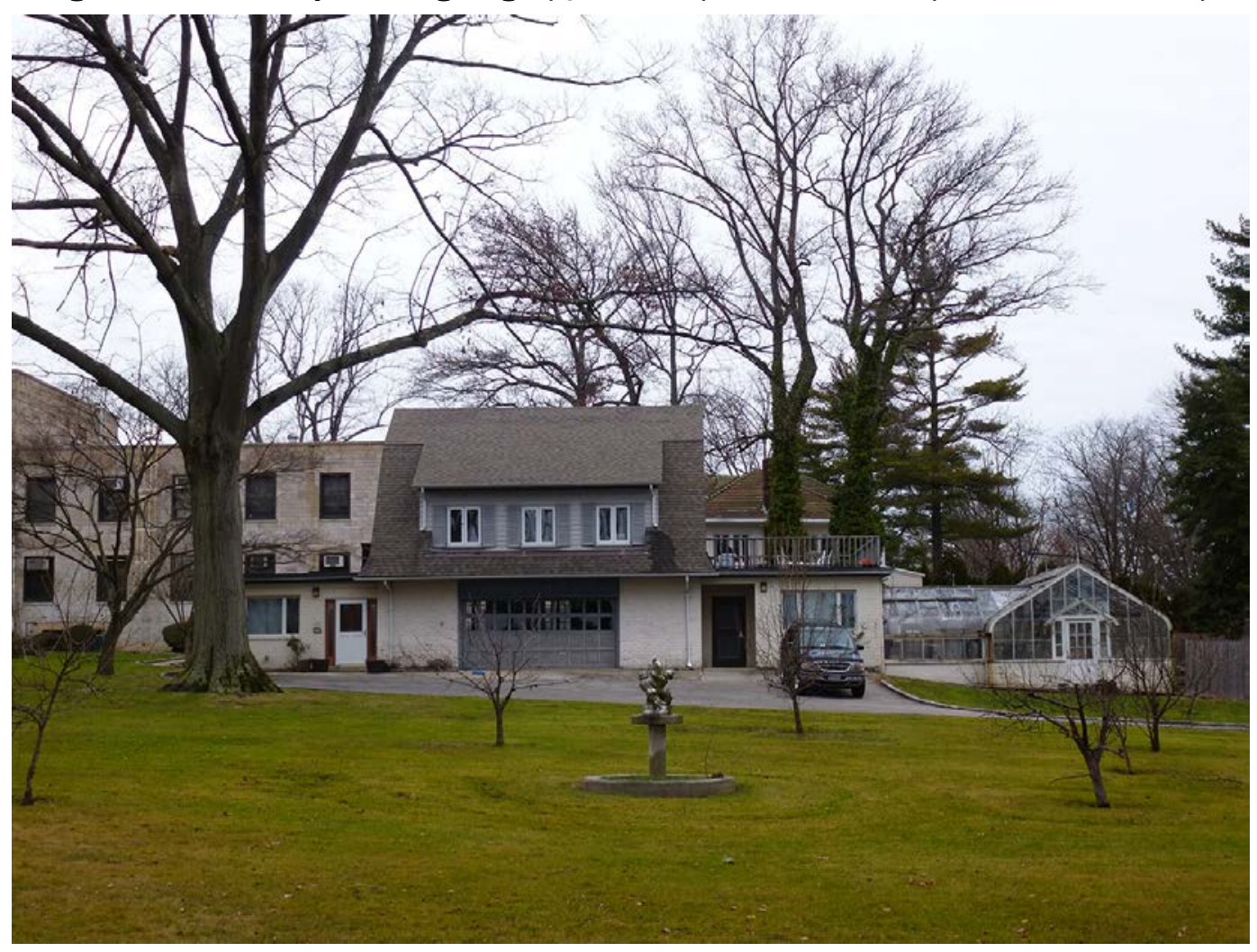

\subsection{Grenwolde Casino (Quarters D)}

Quarters D was constructed in 1912 for use by the Grenwolde Association as a bathhouse and recreation building (called a Casino), and it is the oldest building on the USMMA campus. It is a rectangular two-story house. The east side of the house is built into the side of the bluff, so the entrance to the house is on the second floor. The west side faces onto Long Island Sound and is a full two stories in height. The west side has an open loggia (a remnant of a wraparound veranda) on the top floor and a threearched arcade on the ground floor (Figure 9). The walls are covered in stucco, and the building has a hipped roof covered in asphalt shingles. The original style of the building was Italian Renaissance Revival. 
Figure 9. West facade of Grenwolde Casino (now Quarters D) (USMMA 2013).

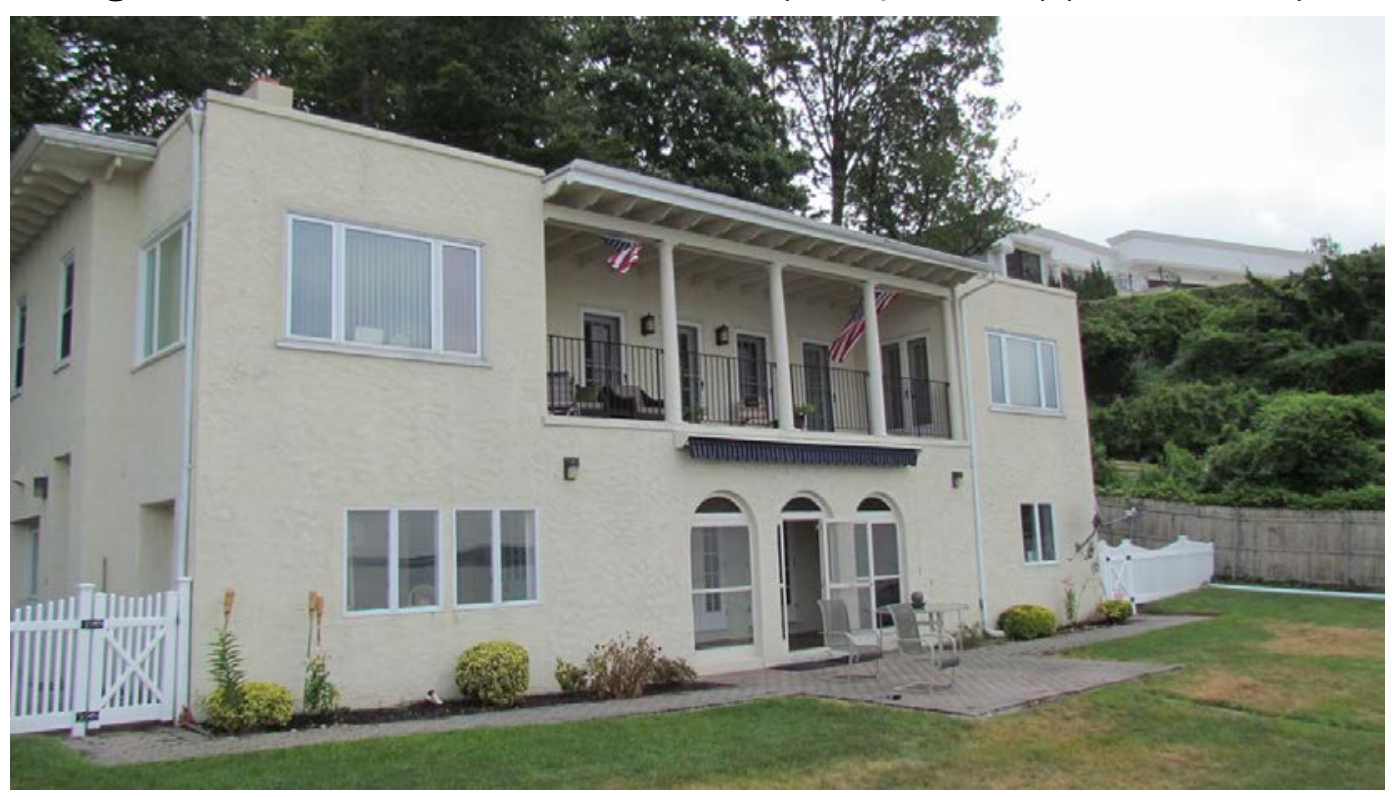

\subsection{Meighan house (Melville Hall)}

It is not known when Melville Hall (Meighan house) was constructed. It is part of the Grenwolde development, but it does not follow the design aesthetic of Grenwolde since it is in the Mediterranean style (Figure 10). It is a large two-story house covered with stucco. The former house faces east and has a central entrance. The hipped roof is covered in variegated Spanish tile. The building is now utilized as a meeting and conference facility, and a large one-story addition was constructed to house a ballroom. The ballroom has a window-wall of smoked glass. 
Figure 10. Photograph of front facade of Meighan house (Melville Hall), 1965

(USMAA Library).

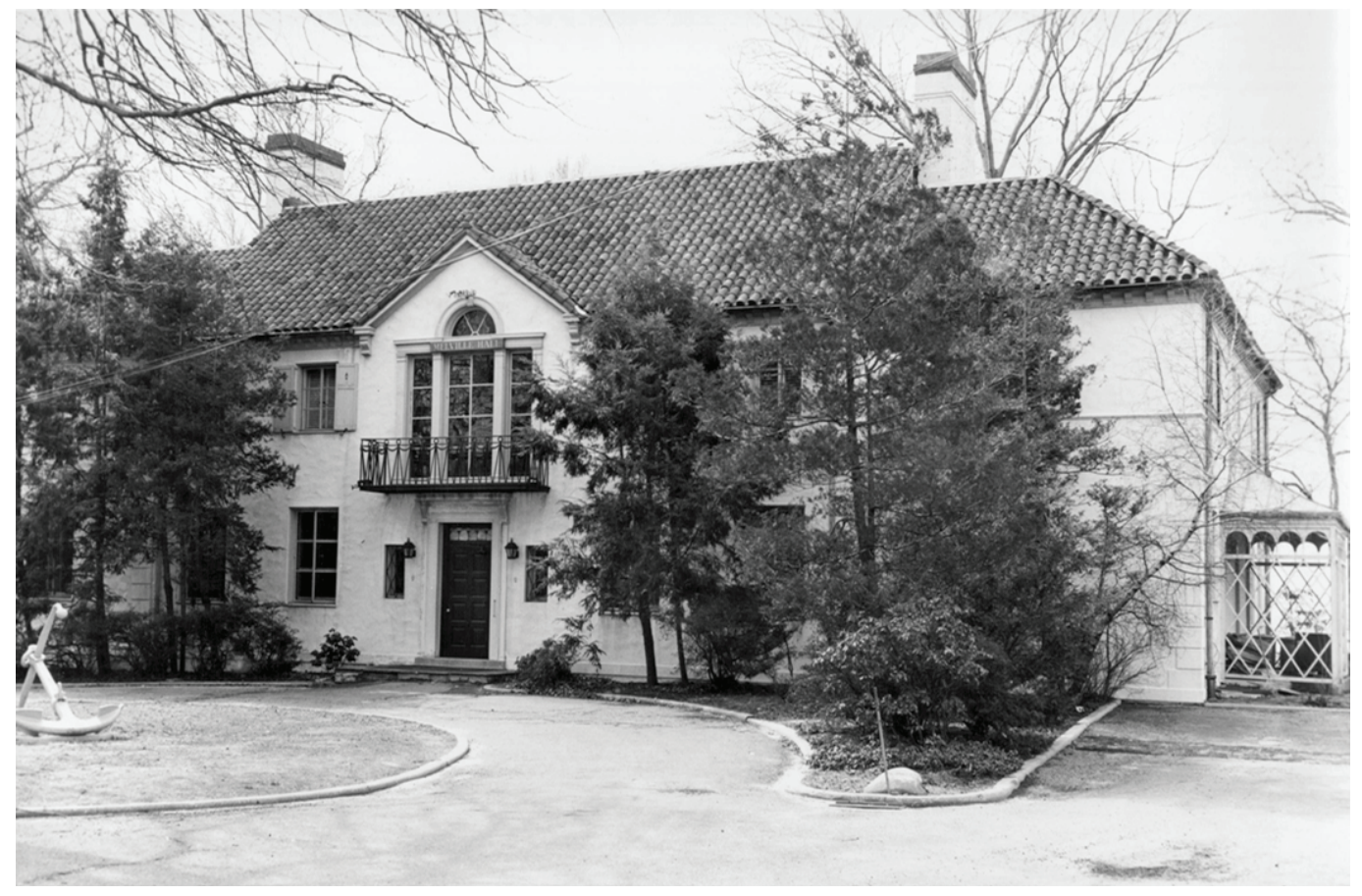

\subsection{Meighan garage (Quarters K)}

As previously stated, it is not known when Melville Hall (Meighan house) nor its garage (Figure 11) were constructed. Like the house, the garage is part of the Grenwolde development, but it does not follow the design aesthetic of Grenwolde since it is in the Mediterranean style. The garage is currently used as Quarters K, and it is two-stories and covered with stucco.

Figure 11. View to the south of Meighan house garage (Quarters K) (ERDC-CERL, 2013).

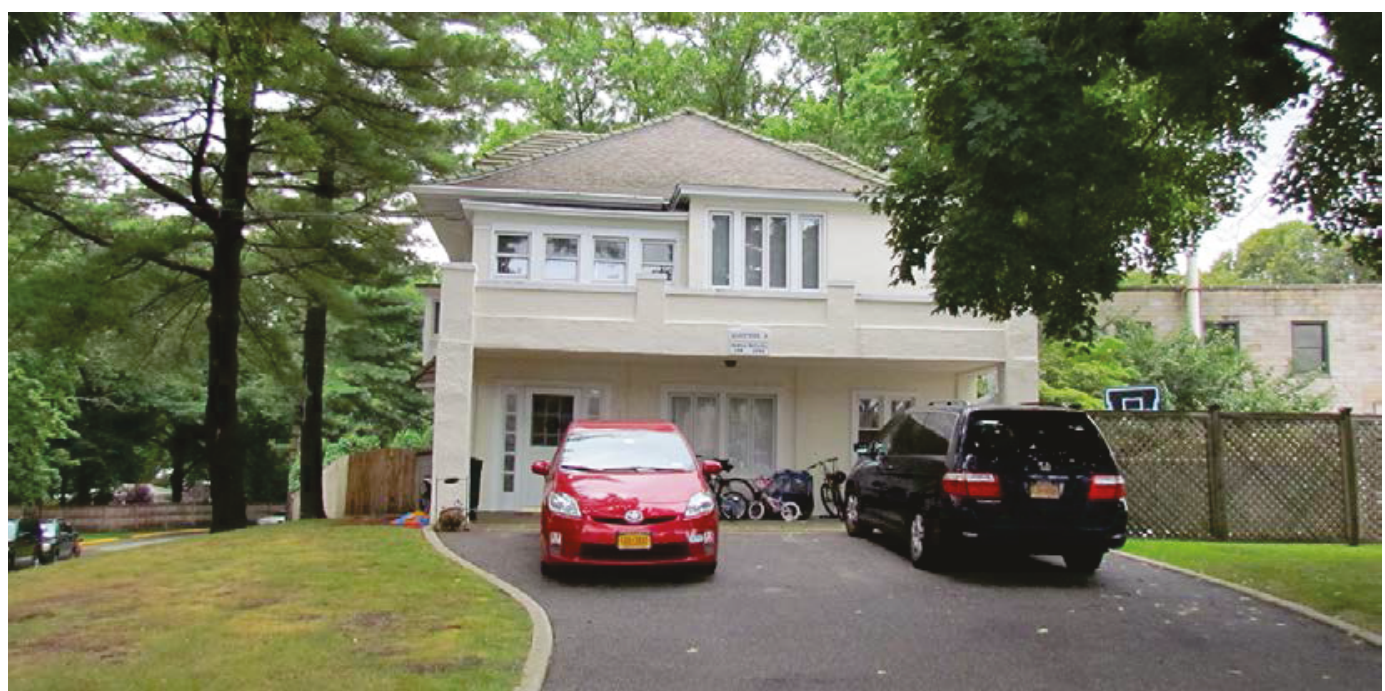




\subsection{Schenck house (Land Hall)}

Land Hall (Schenck house) was constructed circa 1920, but the architect is not known. The house was originally named "Claralea," and it was part of the Grenwolde development although its design did not follow the Grenwolde aesthetic. It is a large, two-story, Italian Renaissance Revivalstyle house covered in stucco, with a large hipped roof covered with green clay tile (Figure 12). The building is now utilized for cadet recreation services.

Figure 12. North facade of Schenck House (Land Hall), 1942 (NARA).

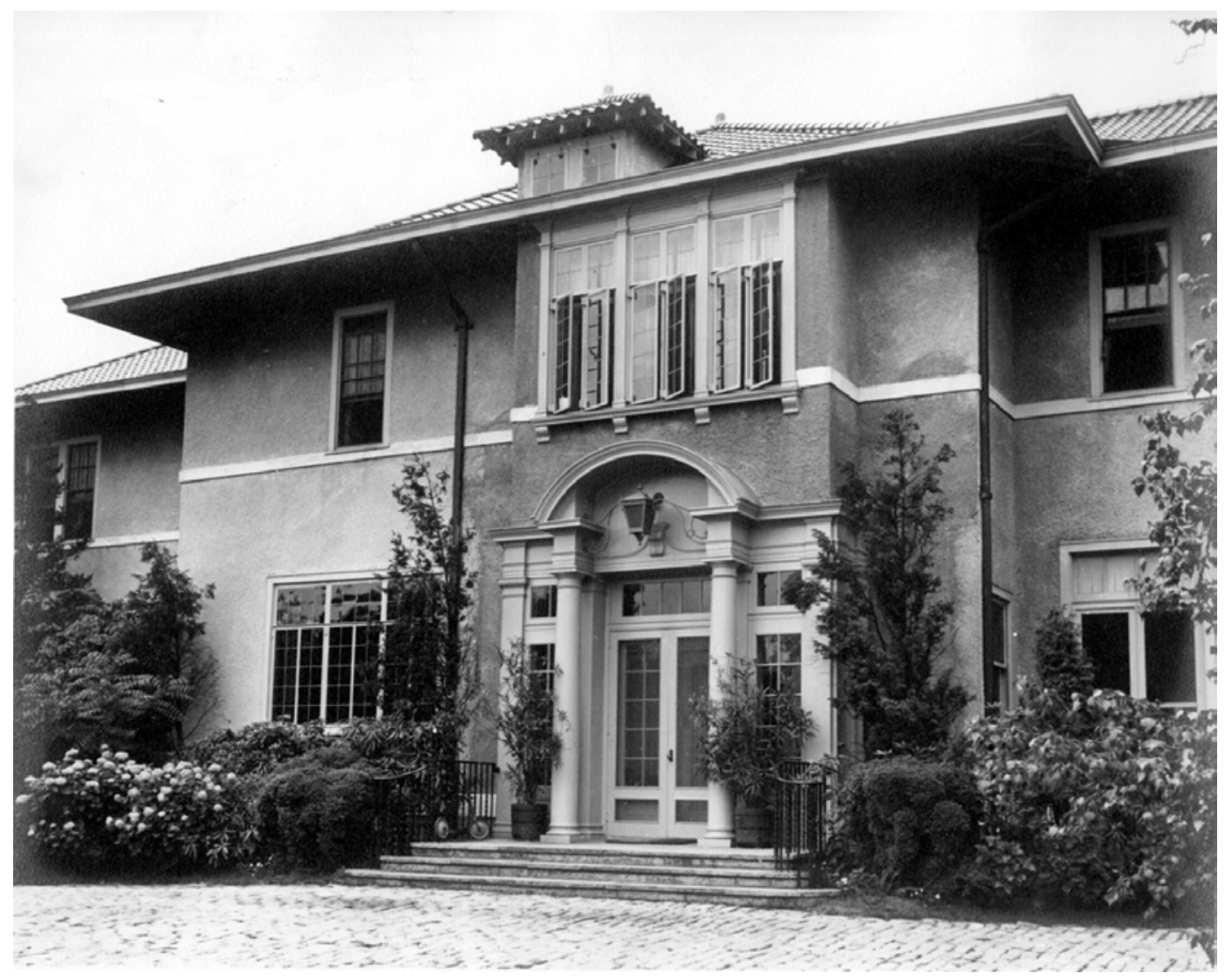

\subsection{Barstow mansion}

The Barstow mansion is one of the remaining structures from the Gold Coast estates period on Long Island. William S. Barstow was a prominent industrialist of the era. The property's centerpiece is the Mediterranean Revival-style Barstow mansion, which is located on the waterfront with expansive grounds (Figure 13). It is likely the mansion was built in 1915 and designed by American resort architect Addison Mizner, who designed other Mediterranean Revival-style mansions on Long Island. An addition 
was designed in 1929 and completed in 1931 by New York City architect Greville Rickard. A secondary structure is the Mediterranean Revival-style former garage. The Barstow mansion has been home to the American Merchant Marine Museum since 1979.

Figure 13. Barstow mansion and drive (ERDC-CERL, 2013).

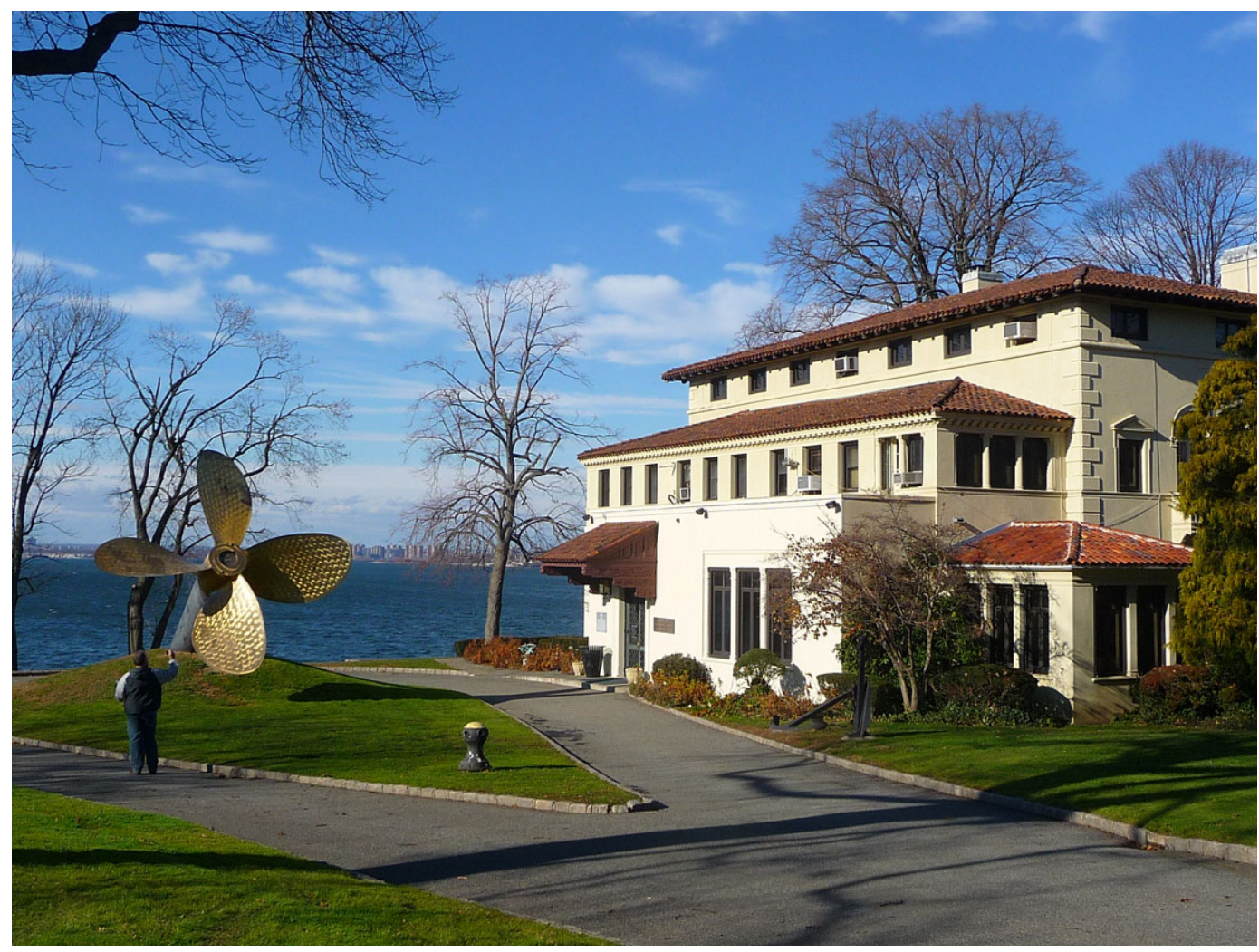

\subsection{Bendel/Chrysler mansion (Wiley Hall)}

Wiley Hall is the main administration building for the Academy. The building originally was constructed for Henri W. Bendel in 1916 and designed by Henry Otis Chapman. It was a two-story residence with a fullheight basement. The mansion, which later became part of the Chrysler estate, features such typical design elements of Beaux Arts Classicism as columns, balustrades, loggias, quoins, Palladian windows, and detailed entablatures, and it is constructed of reinforced concrete finished with stucco (Figure 14). The interior reflects the grandeur of the early twentieth-century Gold Coast estates. The open loggia was enclosed early on by the Academy for use as a dining room for the cadets and is now used for a variety of offices. 
Figure 14. Real estate brochure for Chrysler estate, 1941 (American Merchant Marine Museum).

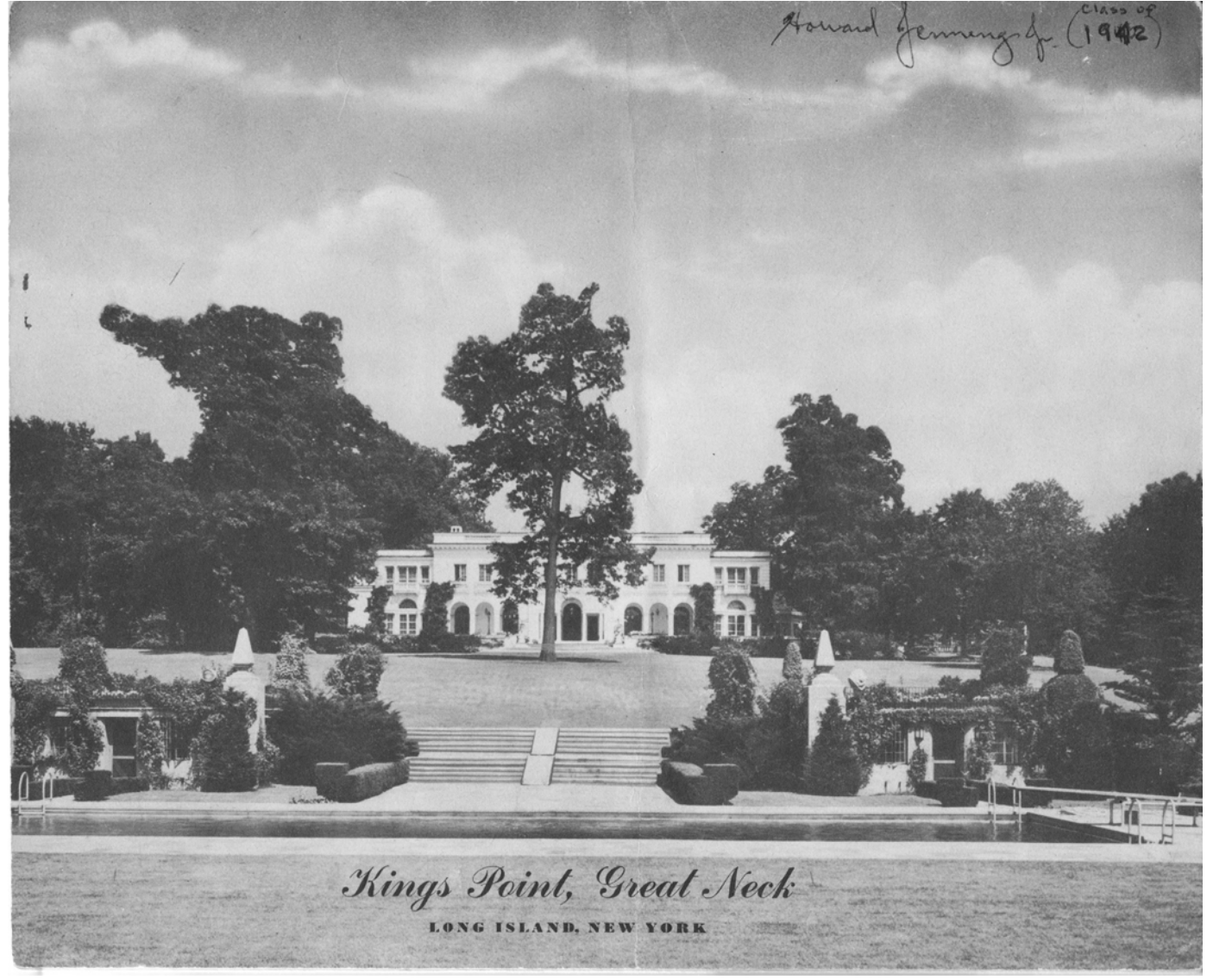

\subsubsection{Academy buildings}

2.1.5.2.1 Barracks: Palmer, Murphy, Cleveland, and Rogers Halls

There are four barracks (dorms) that flank Delano Hall and Barney Square on the south side of the central part of the USMMA campus. They are Palmer Hall and Murphy Hall to the west of Delano Hall, and Cleveland Hall and Rogers Hall to the east. The dorms were all constructed in 1943 and designed by Alfred Hopkins \& Associates. These barracks are threestory concrete-framed buildings with a central hallway and dorms off each side. The walls are constructed of buff-colored concrete masonry units with cast stone (concrete) accents, and the buildings display a generally consistent cornice line, which adds to the visual cohesiveness of the area. The Classical Revival-style buildings are designed with an emphasis on balance and symmetry. The roofs are layered asphalt hidden behind a parapet of the same buff-colored concrete masonry units. The original double-hung, six-over-six wood windows have all been replaced with anodized-bronze double-hung, six-over-one aluminum windows. The 
doors are not original, nor are the light fixtures. The interiors have been heavily remodeled through the years.

\subsection{Barracks: Barry and Jones Halls and the Truxton Arcade}

These two barracks (dorms) that are on the east side of the USMMA's central campus are connected by the Truxton Arcade. The arcade between the two halls allows open-air passage from the quadrangle to O'Hara Hall (gymnasium). Barry Hall is to the south of the arcade while Jones Hall is to the north. They are of the same construction as the four other barracks discussed in 2.1.5.2.1. They were both constructed in 1943, having been designed by Alfred Hopkins \& Associates. The original double-hung, sixover-six wood windows have all been replaced with anodized-bronze, double-hung, six-over-one aluminum windows. The doors are not original, nor are the light fixtures. The interiors have been heavily remodeled through the years.

\subsection{Barracks: Furuseth Hall}

Furuseth Hall was originally constructed as a staff barracks in 1943 and designed by Alfred Hopkins \& Associates. The building is located east of O'Hara Hall, which places it on the eastern edge of the Historic District. It was converted to administrative use at an unknown date. It is of the same construction as the six other barracks discussed in 2.1.5.2.1 and 2.1.5.2.2. The original double-hung, six-over-six wood windows have all been replaced with anodized-bronze double-hung, six-over-one aluminum windows. The doors are not original, nor are the light fixtures. The interiors have been heavily remodeled through the years.

\subsection{Classrooms: Fulton Hall and Bowditch Hall}

There are two large classroom buildings that flank the Bland Library on the north side of the central part of the USMMA campus. Fulton Hall is west of the library, while Bowditch Hall is to the east of the library. They were both constructed in 1943 and designed by Alfred Hopkins \& Associates. They are four-story concrete-framed buildings with a central hallway and classrooms off each side. Bowditch Hall has a large auditorium on the building's north end. The walls are constructed of buffcolored concrete masonry units with cast stone (concrete) accents, and the buildings display the same consistent cornice line as the barracks buildings discussed in 2.1.5.2.1. These Classical Revival-style buildings are 
designed with an emphasis on balance and symmetry. The interiors of these two classroom buildings have been heavily remodeled through the years.

\subsection{Mess hall: Delano Hall}

Delano Hall is a large two-story mess hall (dining facility).The front of it faces onto Barney Square, and it is connected by hyphens to Murphy Hall on the west and Cleveland Hall to the north. It was constructed in 1943 and designed by Alfred Hopkins \& Associates. It is a concrete-framed building with a large dining room on the top floor and large kitchen behind that (toward the south). The basement level contains several stores, a restaurant, and restrooms. The walls are constructed of buffcolored concrete masonry units with cast stone (concrete) accents, and the buildings display the same consistent cornice line as the other Academy buildings previously discussed. The exception is the large porticoed entrance that faces onto Barney Square. The front-gabled portico has square, cast concrete square. Delano Hall is in the same Classical Revivalstyle as the rest of the central campus.

\subsection{Gym: O’Hara Hall}

O'Hara Hall was constructed in 1943 as the Academy's drill hall and gymnasium. The exterior is covered in the same buff-colored concrete masonry units and cast stone architectural details as the rest of the campus buildings designed by Alfred Hopkins \& Associates. The large, distinctive, bow roof was constructed with glue-laminated wooden trusses. Concrete buttresses on the north and south sides structurally support the roof's weight. The front (west) facade of the building was designed in the Classical Revival style and features a double-height, square-columned portico, while the rear (east) facade is much more utilitarian. The natatorium, constructed in 1978, is connected to O'Hara Hall on the southwest by a hyphen. The natatorium is a steel-framed building covered in concrete masonry units and stucco. It has large opaque windows on the east and west sides of the facility. It is a noncontributing feature to the Historic District.

\subsection{Admissions Center}

The Admissions Center is sited north of the Vickery Gate. It was constructed in 1943, and it has a large addition constructed in the 2000 s. 
The building is two stories tall, and the east and south facades have the same buff-colored concrete masonry units as the rest of the 1943 Academy buildings. The roof is hidden by a parapet, with the words U.S. Merchant Marine Academy inscribed on the eastern portion of the parapet. The building's addition to the north is a concrete masonry unit building with a barrel roof; a large portion of the original west facade of the Admissions Center was replaced with concrete masonry units similar to the addition. The original double-hung, six-over-six wood windows have been replaced with anodized-bronze, double-hung aluminum windows.

\subsection{Fitch Building}

The Fitch Building was originally constructed as offices and workspace for the public works employees at the Academy; it was constructed in 1943 and designed by Alfred Hopkins \& Associates. The building is located to the west of Fulton Hall and to the east of Samuels Hall. It was converted for administrative use at an unknown date.

\subsection{Samuels Hall}

Samuels Hall was originally constructed to provide academic space for seamanship and visual signaling training courses; it was constructed in 1943 and designed by Alfred Hopkins \& Associates. The building is located to the west of the Fitch Building. The walls are constructed of buff-colored concrete masonry units with cast stone (concrete) accents, and the building displays the same consistent cornice line as the other buildings previously discussed.

\subsection{U.S. Merchant Marine Memorial Chapel}

The chapel was designed by Eggers \& Higgins and finished in 1962. The chapel faces north and is located on the waterfront, to the west of Palmer Hall. The chapel contains a sanctuary and chaplain's offices. It is designed in the Classical Revival style similar to the earlier buildings of the Academy; however, the construction is of buff-colored brick instead on concrete masonry units. The Classical Revival steeple serves as a navigational beacon, and the light sits 102 feet above sea level. The interior is large open nave with terrazzo flooring. The altar is dominated by a rotating altar to serve the different religions of the cadets. The large windows on the east and west are clear glass while the smaller windows in 
the altar have colored glass. The interior of the chapel is a contributing element to the Historic District.

\subsection{Bland Library}

The Bland Library is Brutalist-inspired building designed by Eggers \& Higgins and opened in 1969. It sits on the northern end of the central area of campus, and it is flanked by Fulton Hall on the west and Bowditch Hall on the east. It is on axis with the entrance to Delano Hall. The first floor of the library is covered in the same buff-colored concrete masonry units as the older buildings designed by Alfred Hopkins \& Associates in 1942. The second floor is a concrete grid with narrow, tall windows.

\subsection{Patten Medical Clinic}

The Patten Medical Clinic is a three-story building with two-story wings, utilizing the same buff-colored concrete masonry units and cast stone architectural details as the rest of the 1942 buildings. It was constructed in 1943 to the south of Delano Hall. A large ambulance bay is located on the north side, while the south side faces the former formal garden of the Neiley house. Most of the original elements of the garden are gone, but the parterre does have grass and a formal flagstone walk. The original windows were replaced at some point with one-over-one, anodized-bronze metal windows. The doors are replacements as well.

\subsection{Noncontributing Buildings}

Buildings that are noncontributing to the Historic District (and their construction date) include: Berger Hall (1985), Gibbs Hall (1980), Quarters G (date unknown), Yocum Sailing Center (1984), the natatorium (1978), and a guard shack.

\subsubsection{Structures}

\subsection{Vickery Gate}

Vickery Gate is the main entrance to the Academy and is situated near the corner of Steamboat Road and Stepping Stone Lane. The gate was constructed in 1943 and designed by Alfred Hopkins \& Associates. The gate consists of two guard rooms on either side of Steamboat Road (Figure 15). The two cast-stone structures are square in plan and are topped by sculpted globe and dolphins, and the sculptures are set atop a stepped 
base with federal eagles at the corners. The words "United States Merchant Marine Academy" in copper lettering are above the doorway opening on the east side of each structure. Both structures have had their original doors removed to allow pedestrians to walk through them, and the original windows have been replaced with anodized-bronze metal windows.

Figure 15. One of the two guard rooms forming the Vickery Gate, the main entrance to USMMA (ERDC-CERL, 2015).

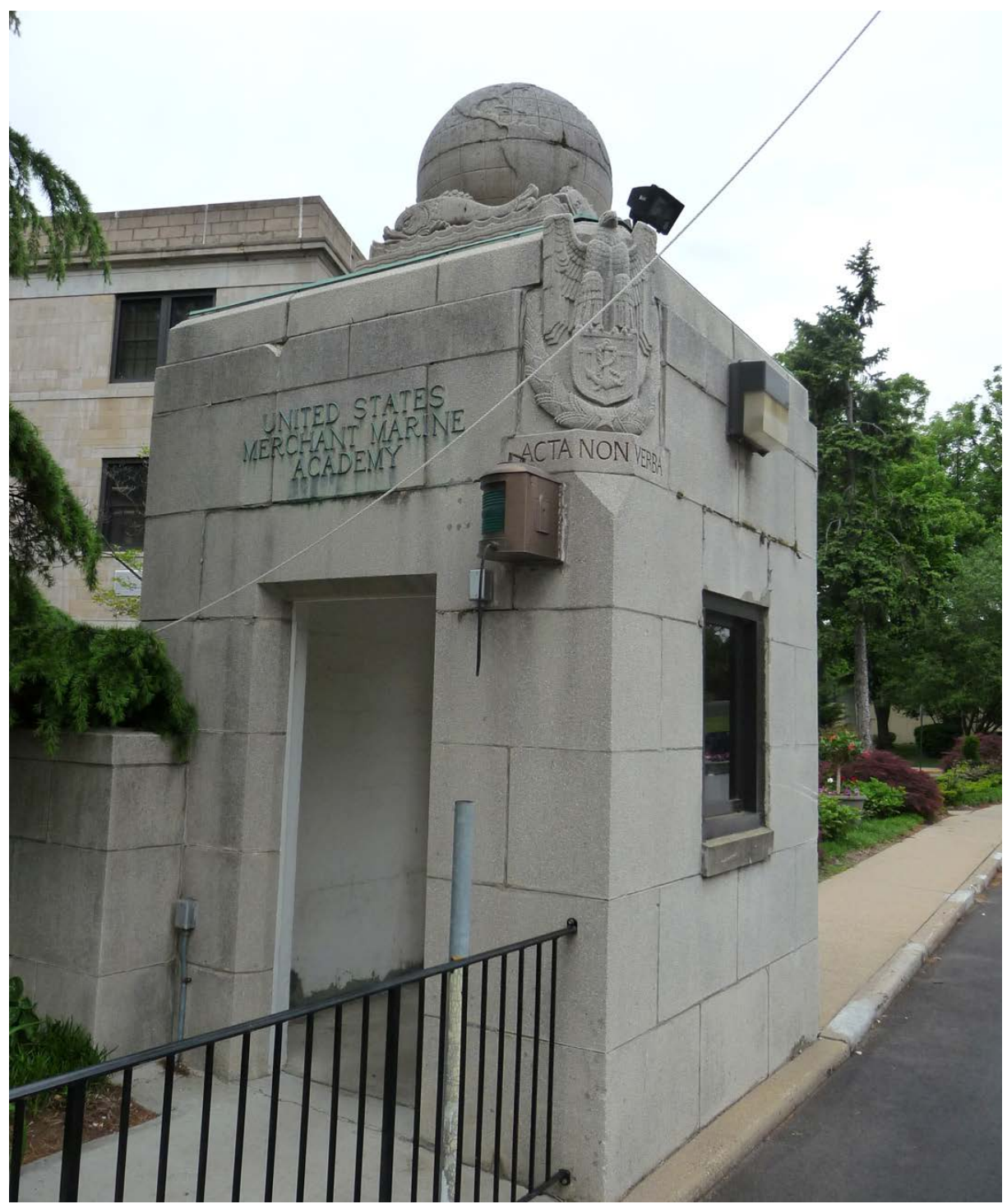

\subsection{Marvin Place Gate}

Marvin Place Gate (originally the main entrance) is situated near the corner of Steamboat Road and Elmridge Road (Figure 16). The gate was constructed in 1943 and designed by Alfred Hopkins \& Associates. The gate consists of two guard rooms on either side of Steamboat Road, similar 
to the Vickery Gate, except that both Marvin Place Gate structures do not have the sculpted globe and dolphins atop a stepped base but both do have the Federal-style eagles at the corners. Both structures have had their original doors replaced with steel doors, but both have their original windows.

Figure 16. Marvin Place Gate (ERDC-CERL, 2015).

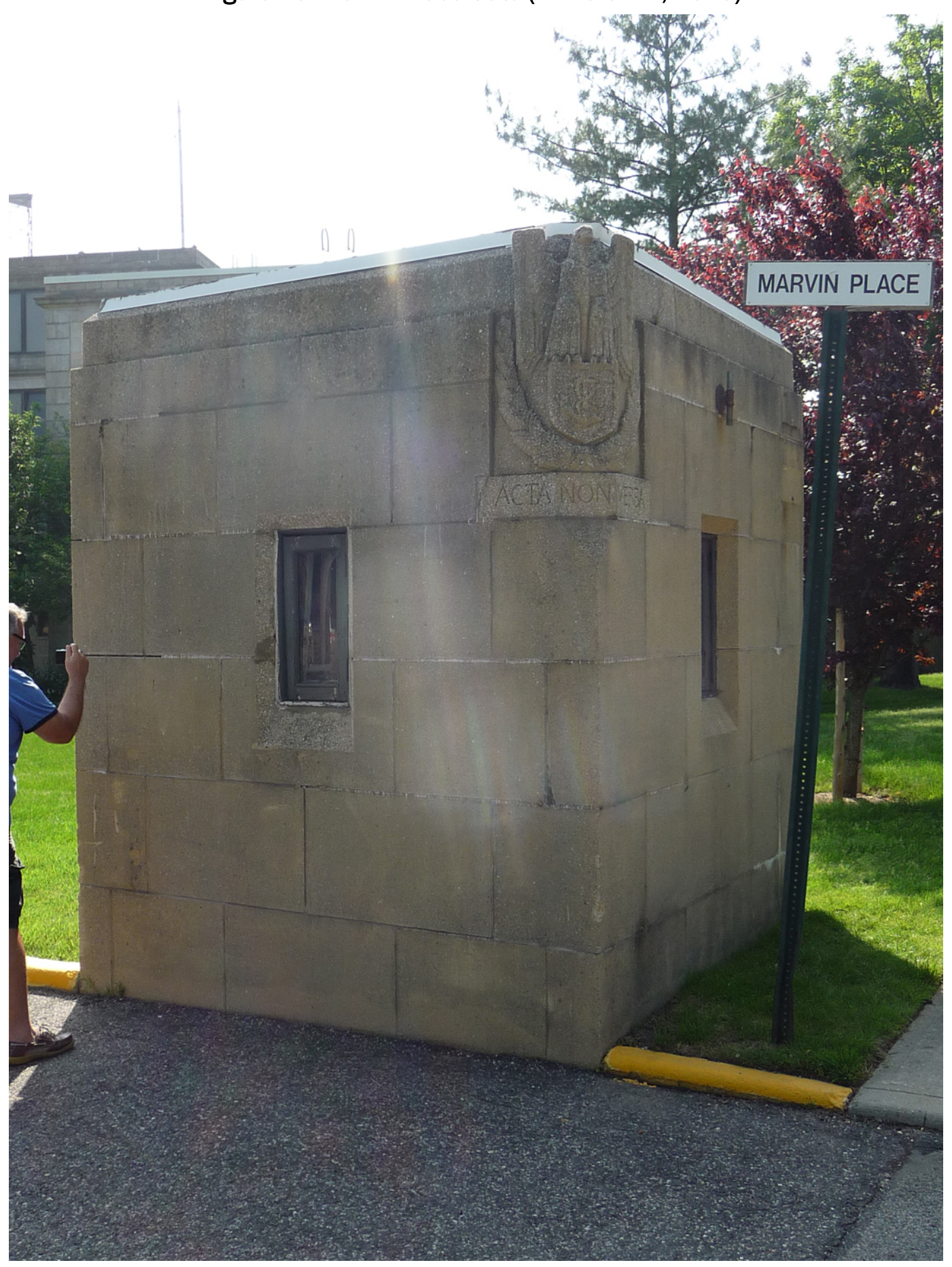




\subsection{Mallory Pier and Crowninshield Boat Shed}

Mallory Pier, a wood and concrete structure, serves as the Academy's main berthing dock (Figure 17). The pier provides a transition between Long Island Sound and Hague Basin. Larger training vessels dock on the outboard side of Mallory Pier, while smaller vessels, such as training dinghies, are berthed along smaller floating docks on the inboard side. The portion of the pier closest to shore dates back to the Chrysler era, while the portion that extends out to surround Hague Basin was built in 1943 . Sections of the pier were rebuilt in 2016 to allow for larger training vessels. Crowninshield Boat Shed dates to the establishment of the Academy in 1942 (Figure 18).

Figure 17. Mallory Pier (ERDC-CERL, 2015).

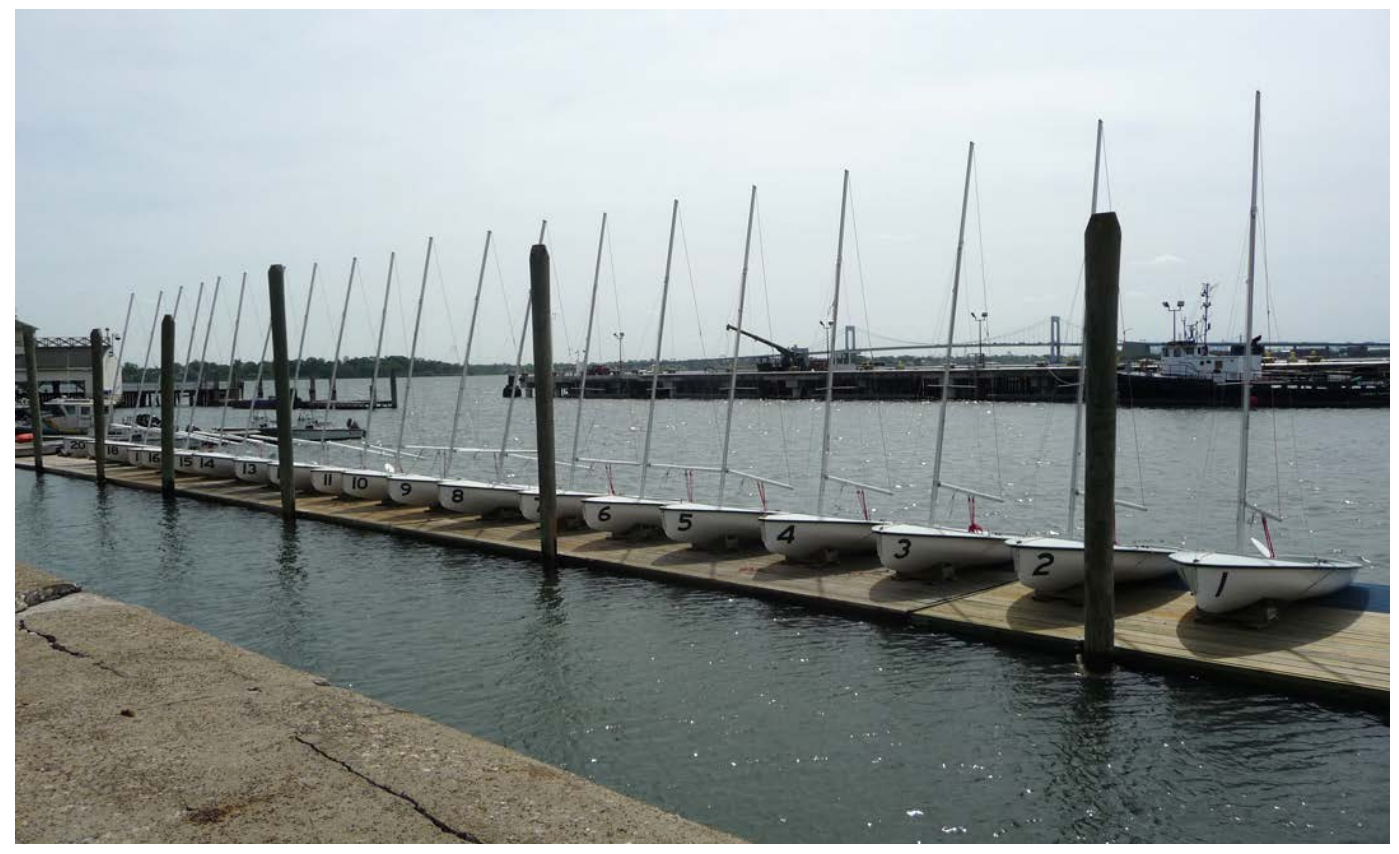


Figure 18. Crowninshield Boat Shed (ERDC-CERL, 2013).

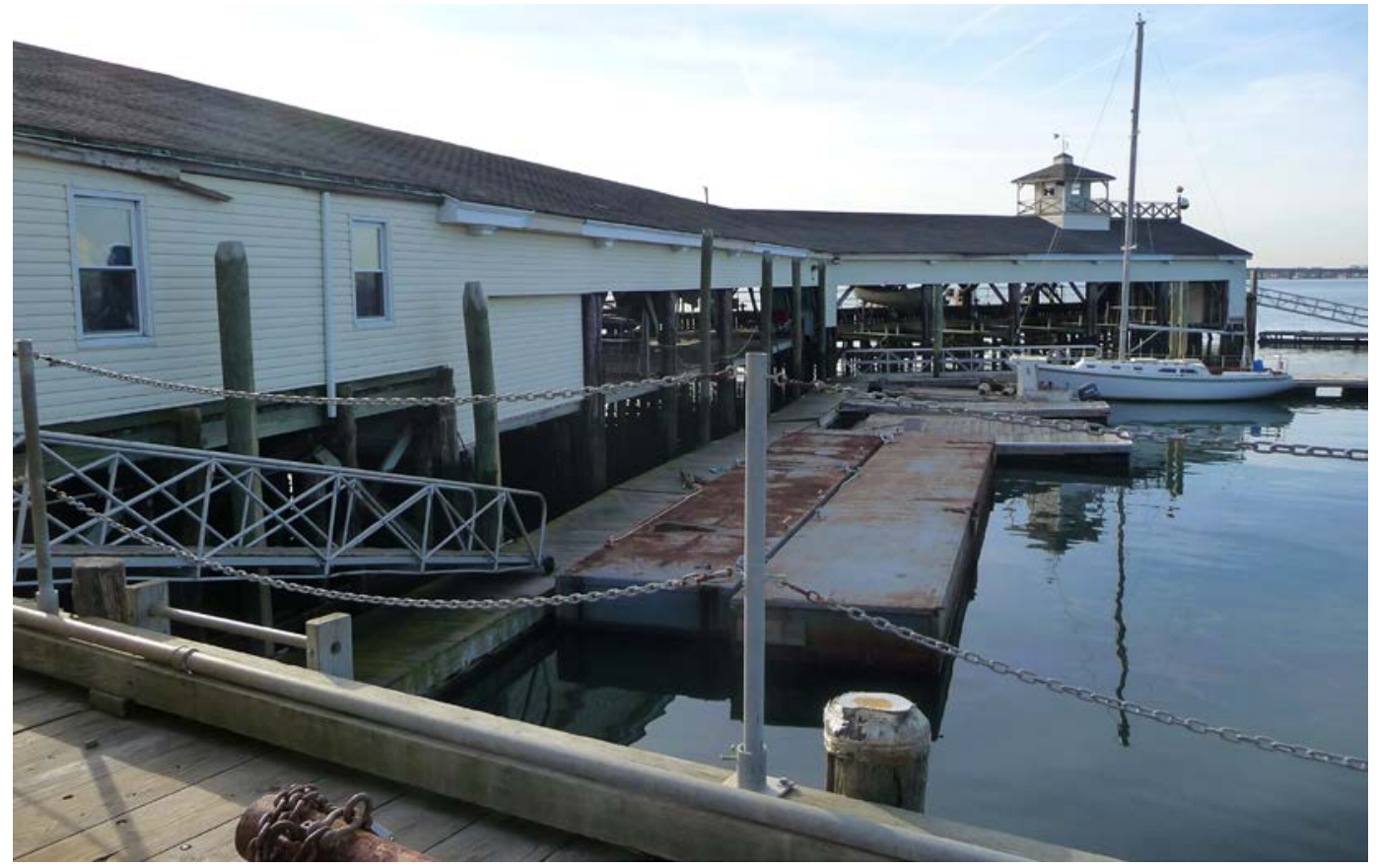

\subsection{Eldridge Pool}

The Eldridge Pool dates to the Chrysler era (circa 1930) (Figure 19 and Figure 20). It is a concrete pool with a concrete surround. It has two associated bathhouses from the same era and an associated mechanical room. 
Figure 19. Swimming race in pool on Dedication Day, 1943 (USMMA Bland Library).

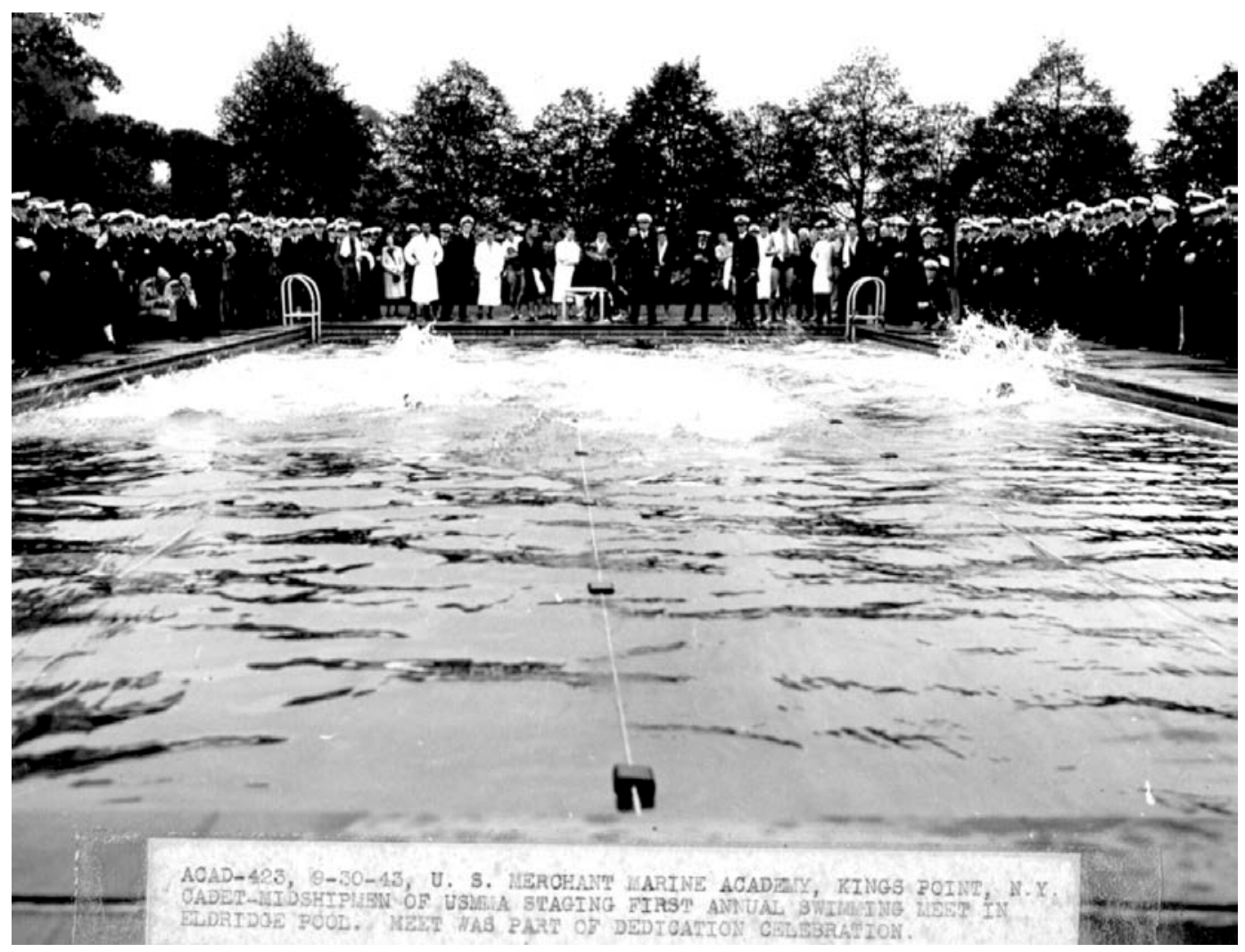

Figure 20. View of Eldridge pool (ERDC-CERL, 2012).

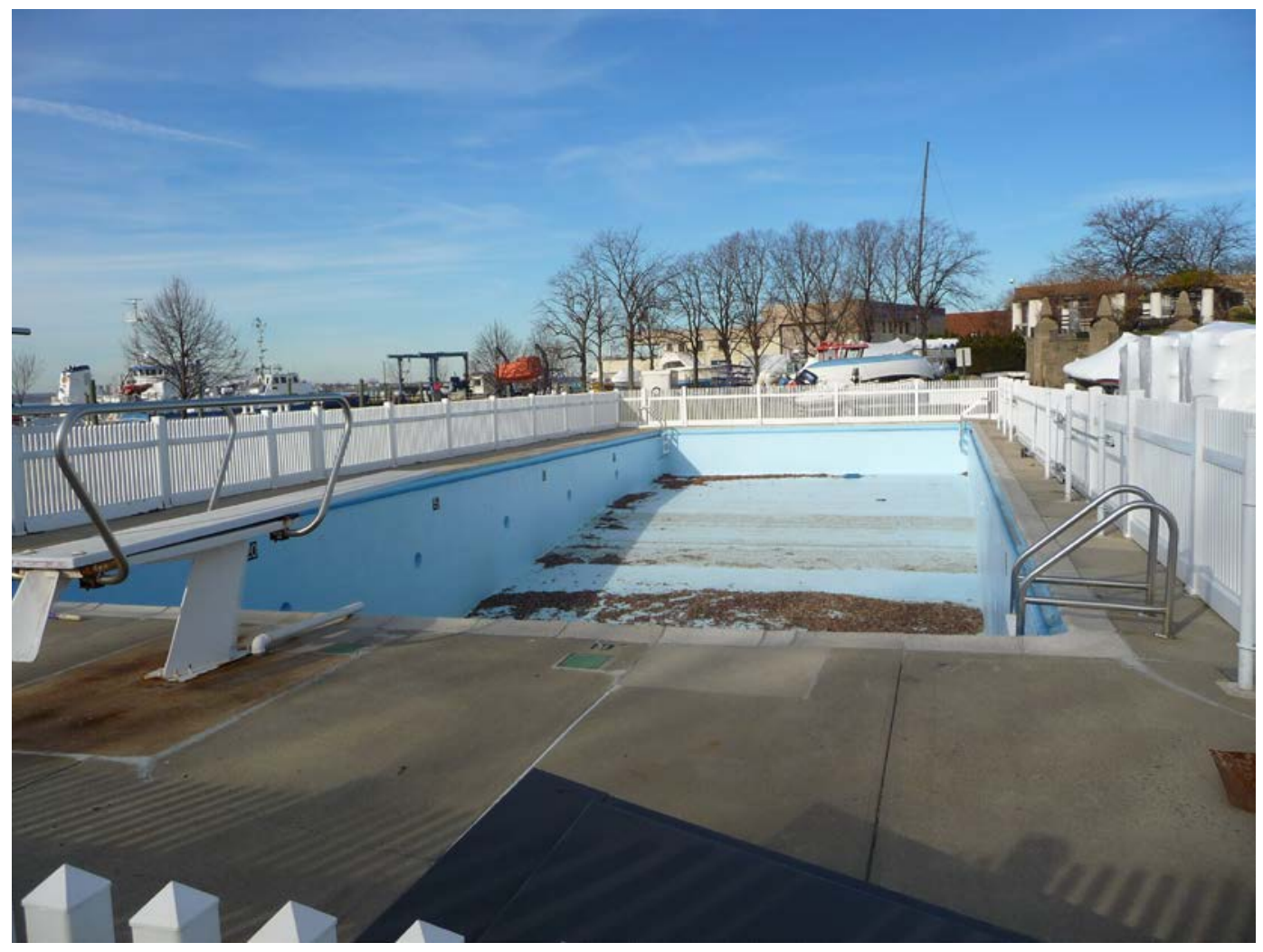




\subsection{Marshall (Schenck) Pool}

Marshall Pool was part of the Schenck Estate when the estate was purchased by the Academy in 1941 (Figure 21). It was enclosed in 1943 by using glass from the Chrysler greenhouse and used for training cadets in water safety during the colder months (Figure 22). The pool is now called Prosser Boathouse (Figure 23).

Figure 21. Marshall Pool newly enclosed, 1943 (USMMA Bland Library).

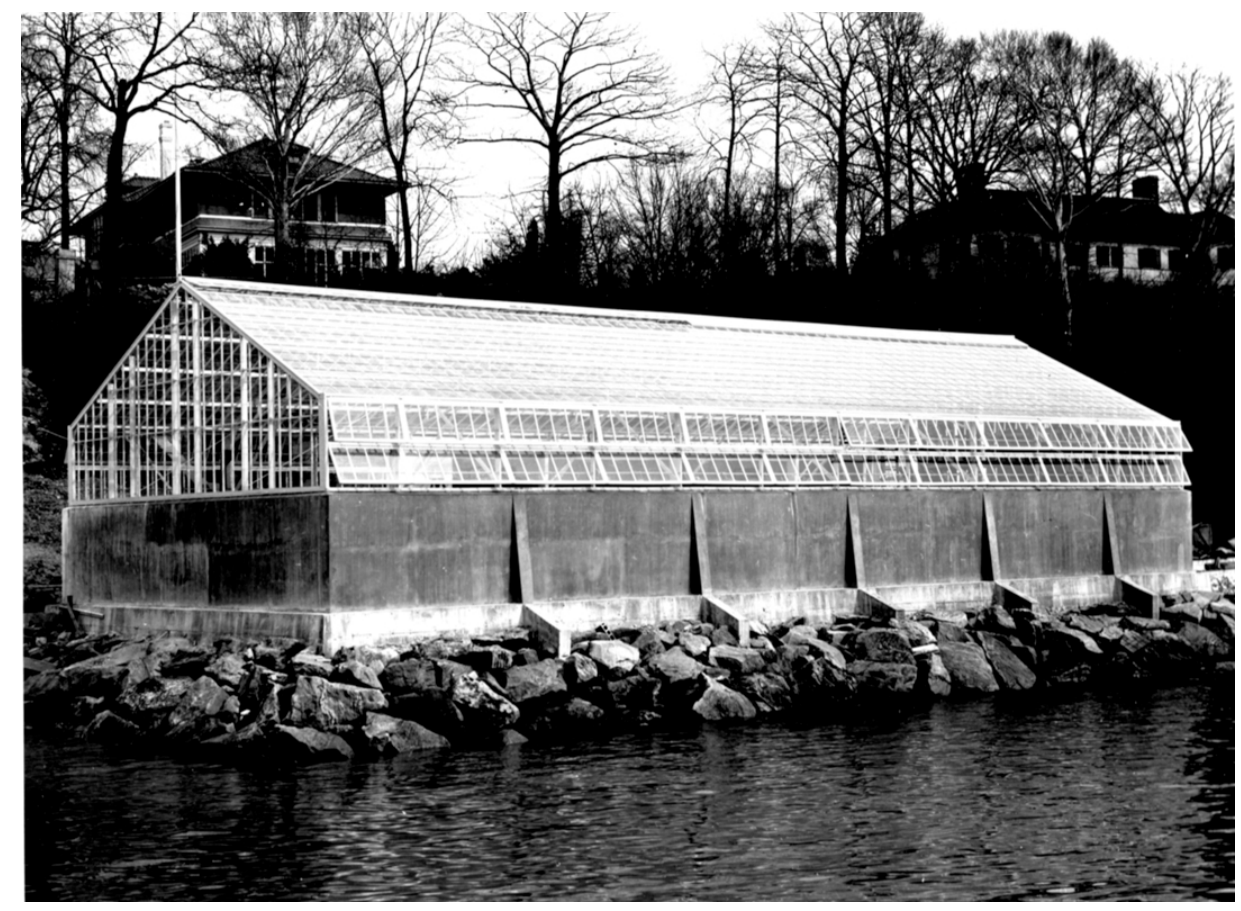


Figure 22. Interior of Marshall Pool, 1943 (USMMA Bland Library).

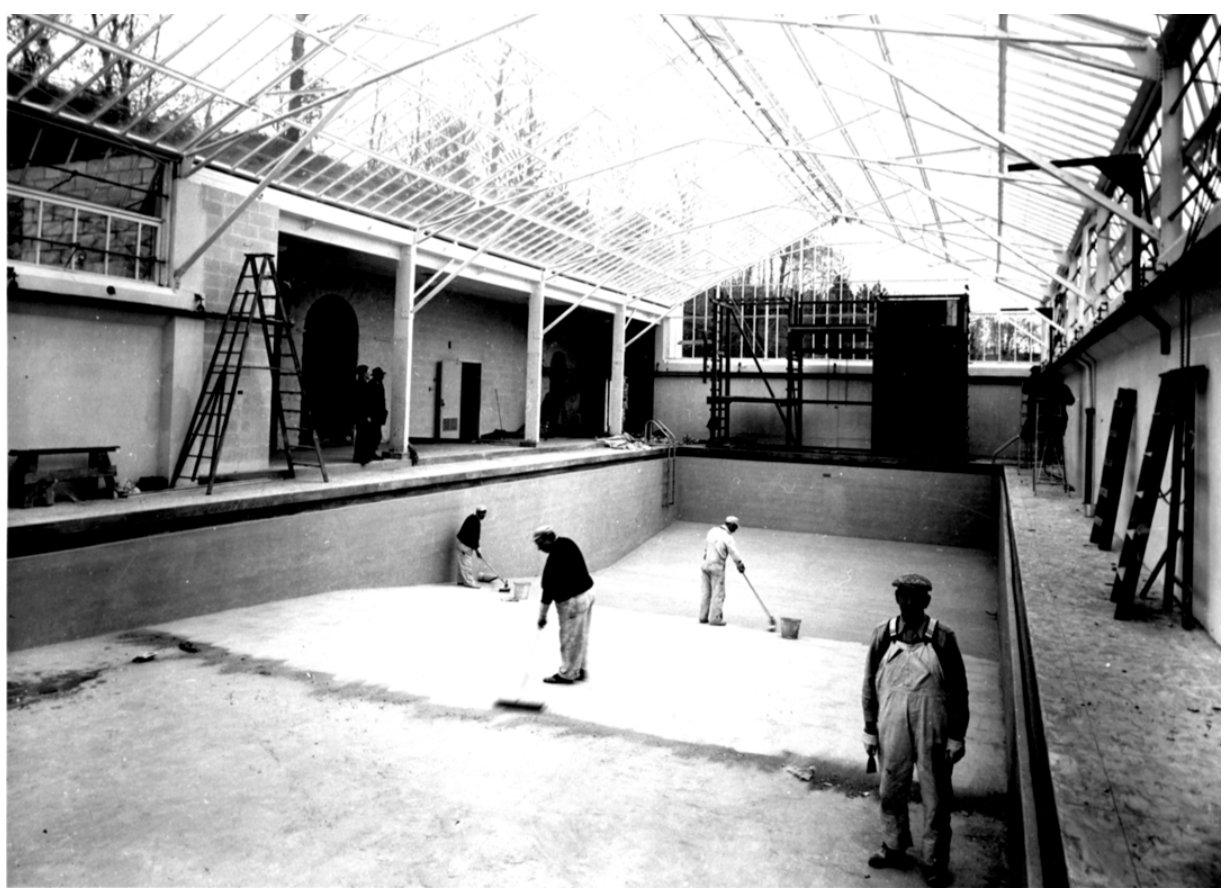

Figure 23. Marshall Pool is now Prosser Boat House (ERDC-CERL, 2013).

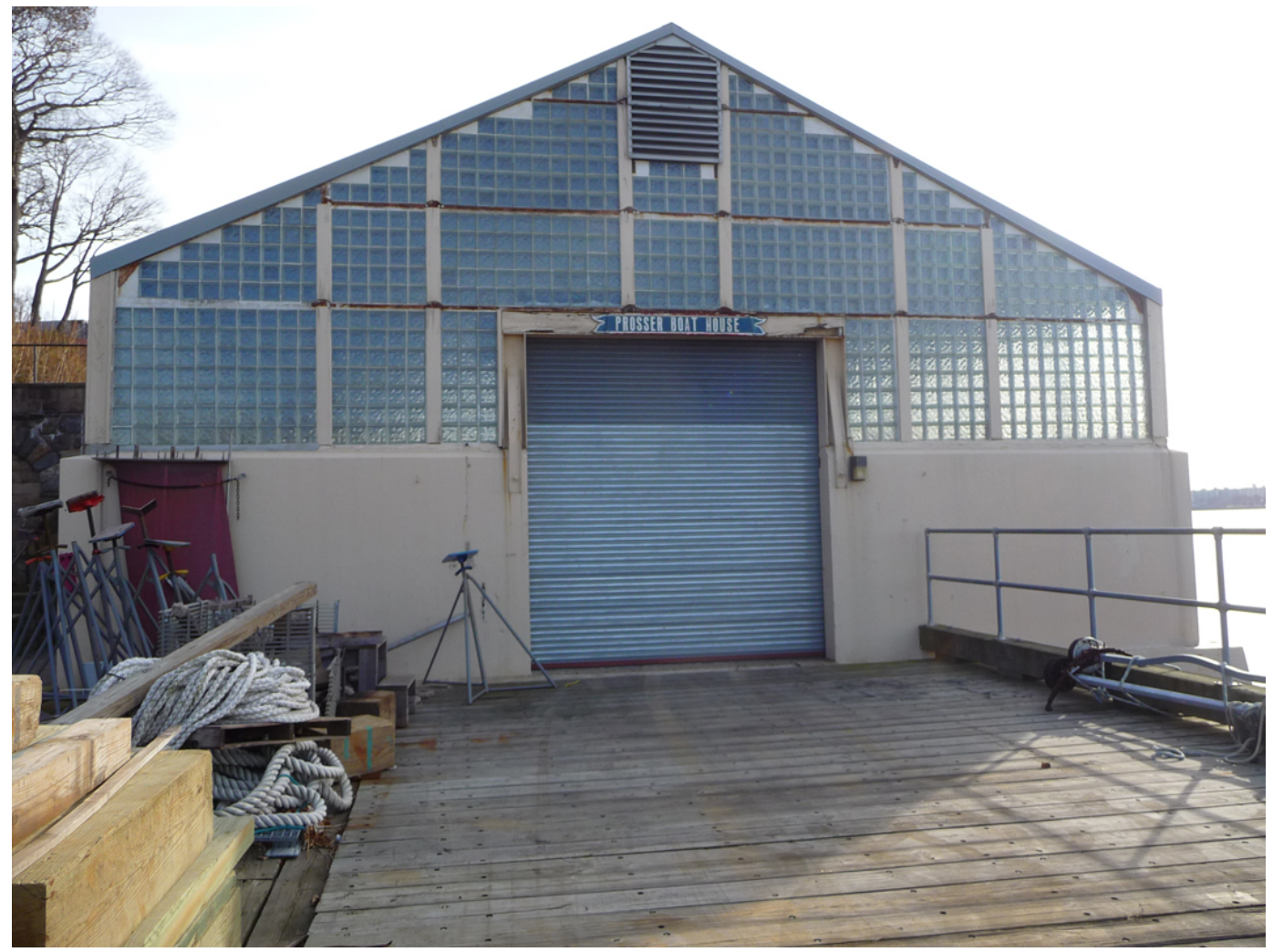




\subsubsection{Vegetation}

No landscape designs or plans were found during research for this project. It is unknown whether there was a design intent to have minimal plantings around the Academy buildings to offset the formal gardens and terraces of the Bendel/Chrysler mansion, or whether money simply ran short during the construction process. All that is known is what can be seen in the historic photographs after the Academy's construction was completed.

\subsubsection{The Quadrangle}

At the heart of the Academy lies the quadrangle. The quadrangle is grasscovered with mature shade trees throughout, many dating to the Chrysler estate (Figure 24) and to the construction of the Academy. Most formal plantings, flowers, and perennials are contained within the formal fabric remaining from the Chrysler estate (Figure 25). However, there are many shrubs and accent evergreens planted along the foundations of all the buildings. Main entrances to buildings are accented with vegetation, and the sides are less planted. For example, the main entrance to Delano Hall is planted with evergreens, flowering trees and some perennials (Figure 26). It appears that the trees depicted in the Alfred Hopkins \& Associates Architects rendering of the USMMA were remnants from the Bendel/Chrysler estate that survived the construction of the Academy, as evidenced in historic photographs (Figure 27, Figure 28, and Figure 29).

Figure 24. View from Bland Library of grove of trees in quadrangle (ERDC-CERL, 2015).

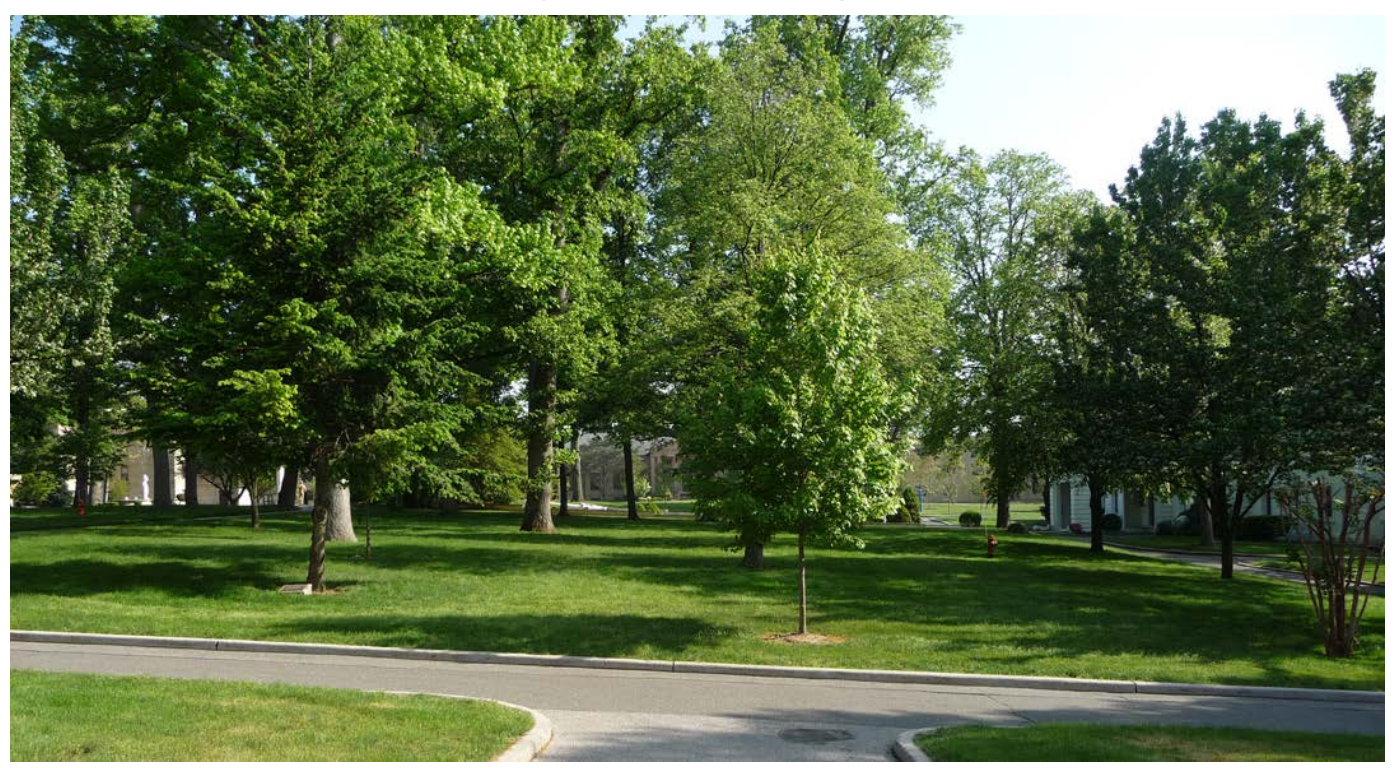


Figure 25. View of formal plantings around Wiley Hall (ERDC-CERL, 2015).

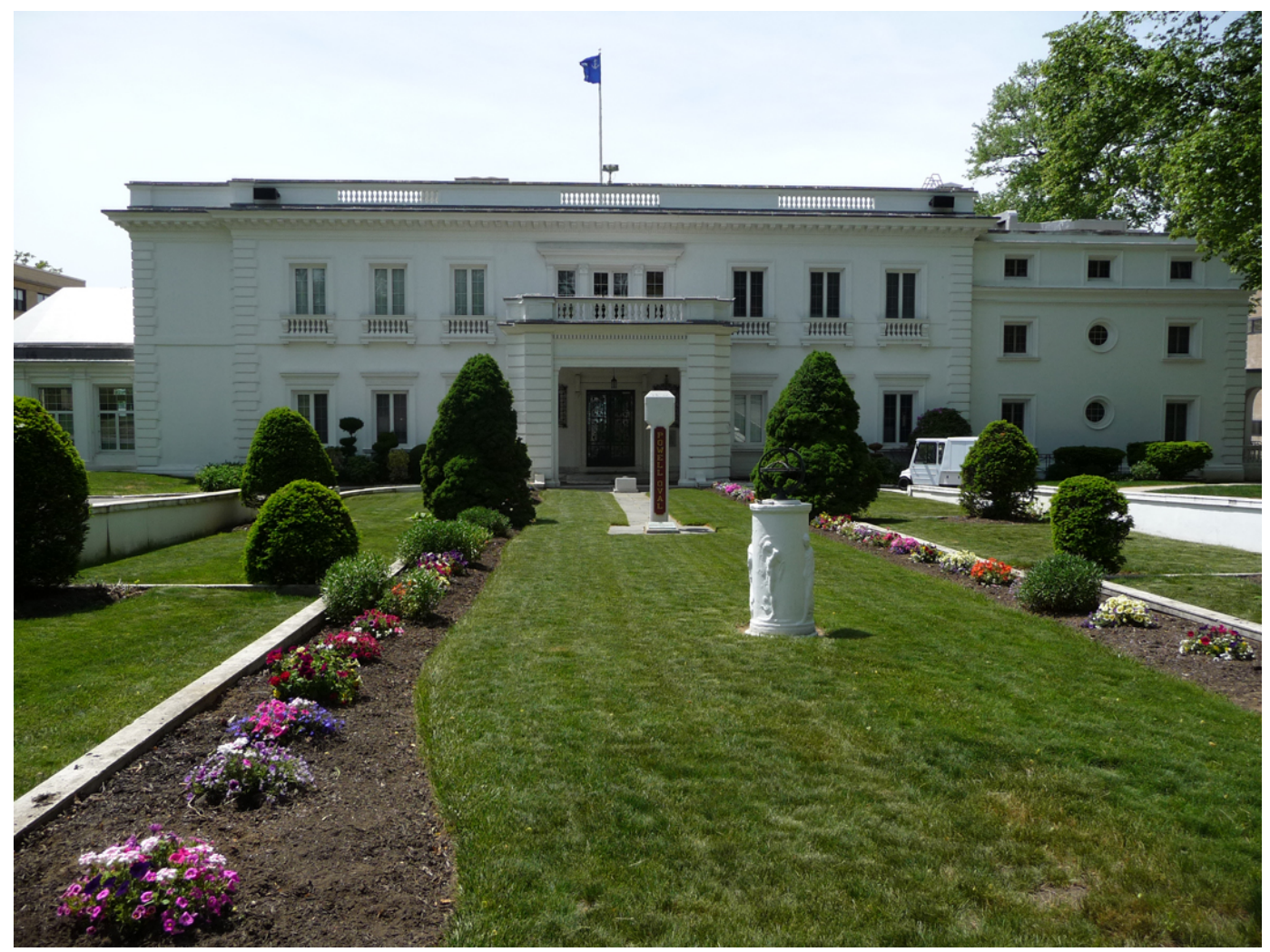

Figure 26. View of plantings in front of Delano Hall (ERDC-CERL, 2015).

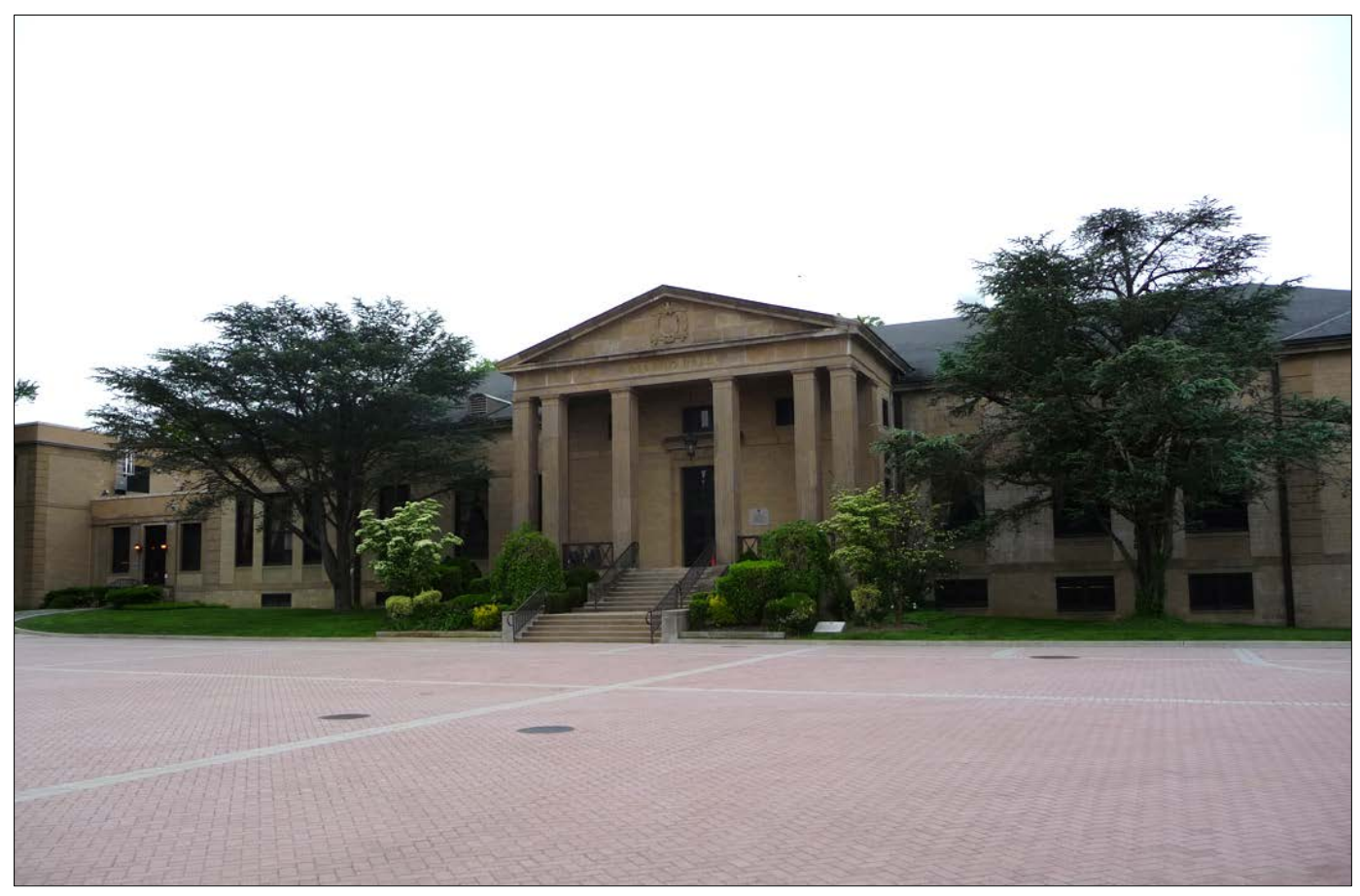


Figure 27. Alfred Hopkins \& Associates Architects rendering of the USMMA, undated (USMMA Bland Library). Note location of trees in quadrangle.

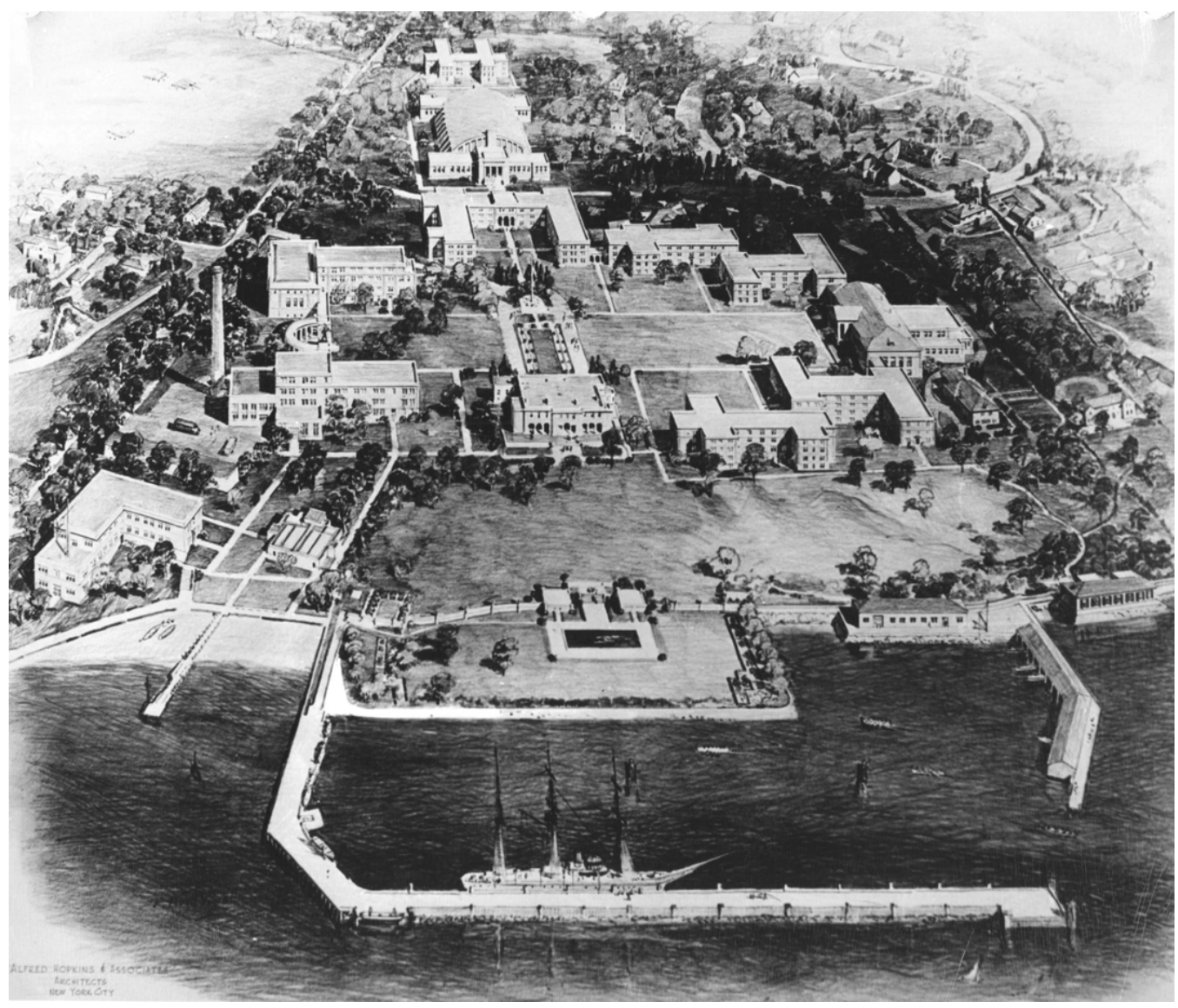


Figure 28. Aerial photograph of Academy showing mature trees in quadrangle remaining from Bendel/Chrysler estate, 1943 (USMMA Bland Library).

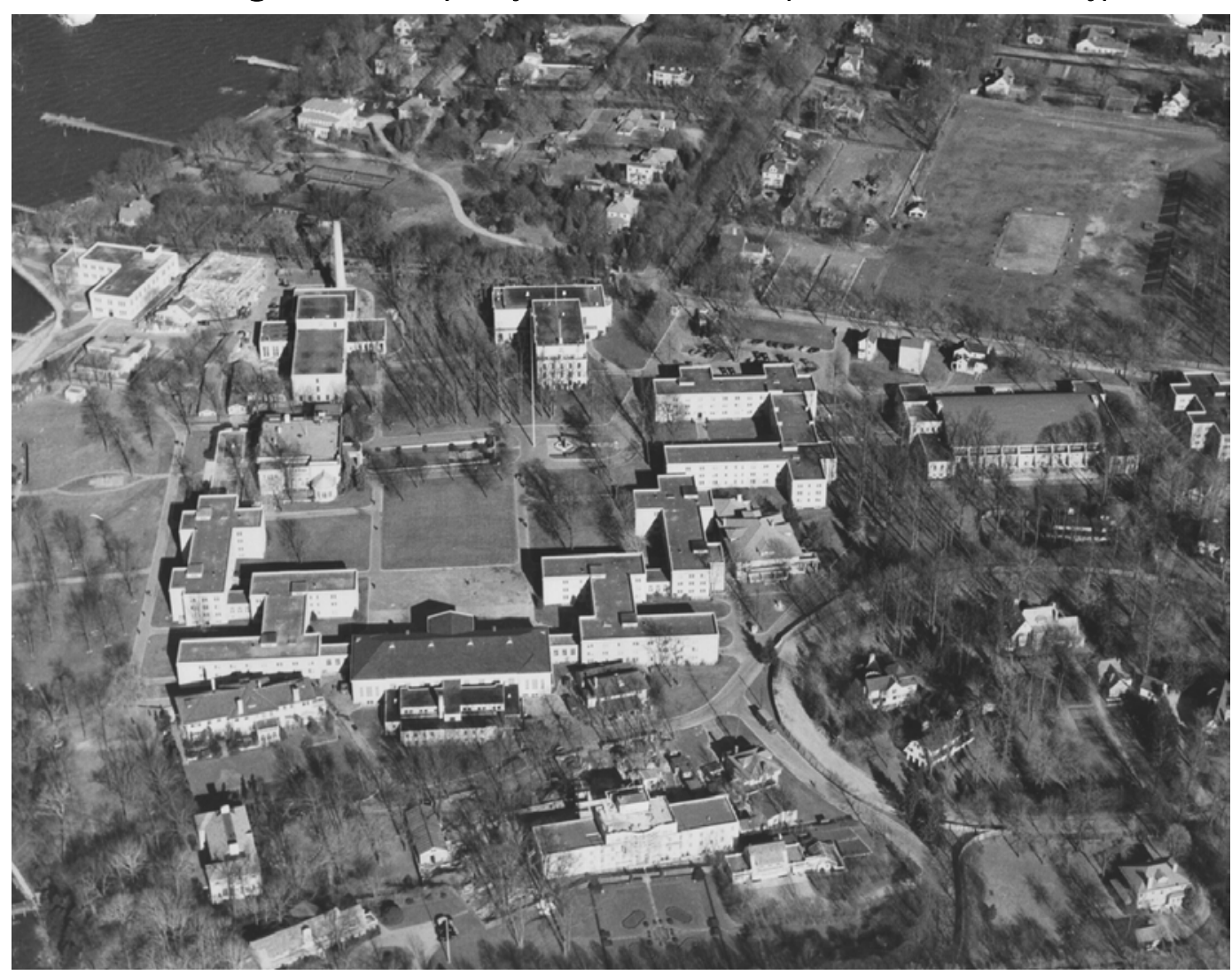

Figure 29. During the construction of Bowditch Hall, 1942 (USMMA Bland Library). Note protective fencing around mature trees to prevent damage during construction.

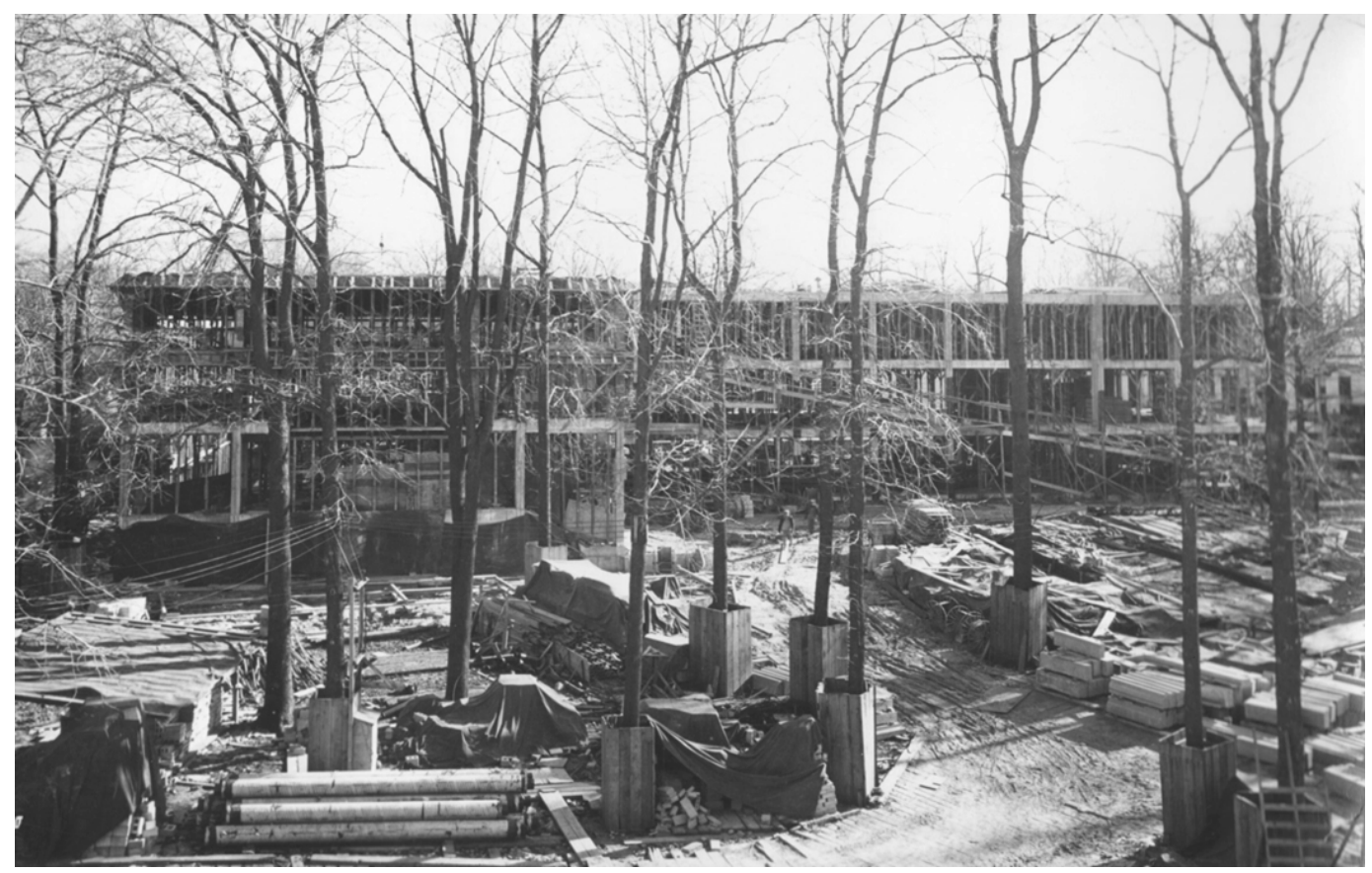


Recent construction in front of Delano Hall has resulted in replanting trees on half of the quadrangle. These recent plantings have been in a rectilinear manner, as evident by rows of trees along the walkways (Figure 30 and Figure 31). This rectilinear arrangement is in contrast to the informal grove on the other side of the quadrangle. In addition, new flower beds were added at the edge of the new drill space in front of Delano Hall (Figure 32). Historically in the quadrangle, flower beds were only in the formal gardens in front of Wiley Hall.

Figure 30. Rows of trees along walkways to Wiley Hall (ERDC-CERL, 2015).

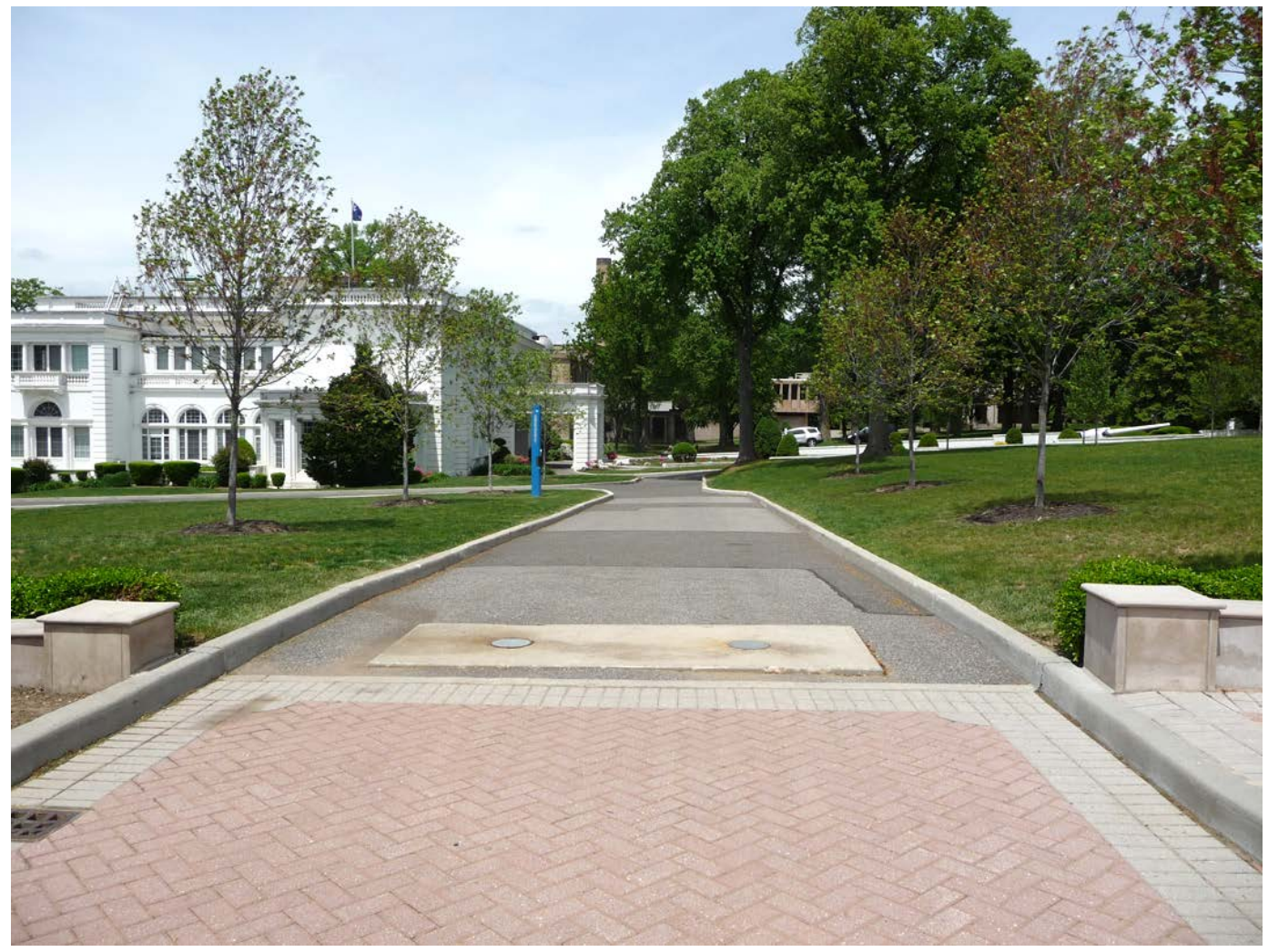


Figure 31. Rows of trees in quadrangle along paths to Delano Hall (ERDC-CERL, 2015).

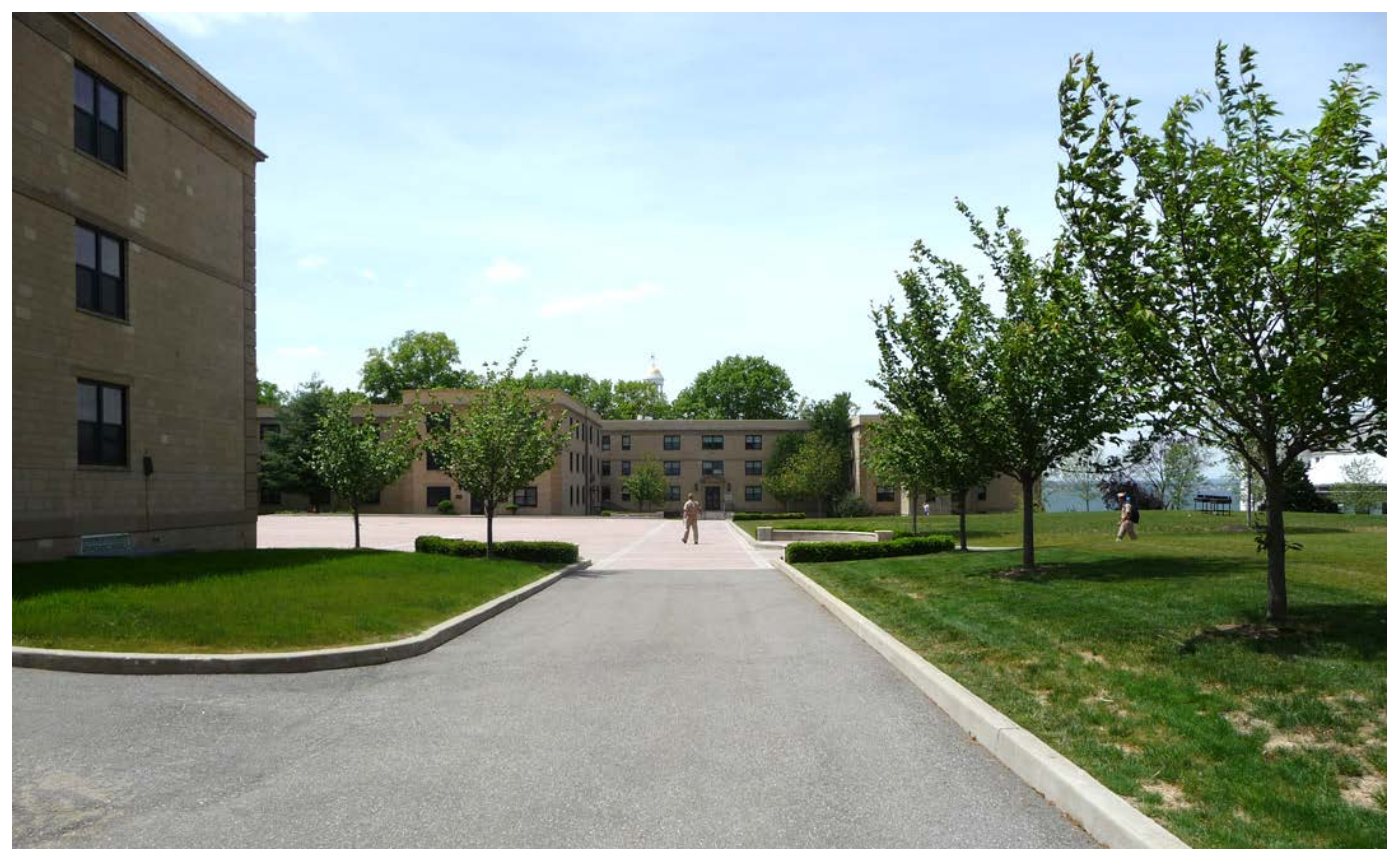

Figure 32. New flower beds adjacent to Delano Hall drill space in quadrangle (ERDC-CERL, 2015).

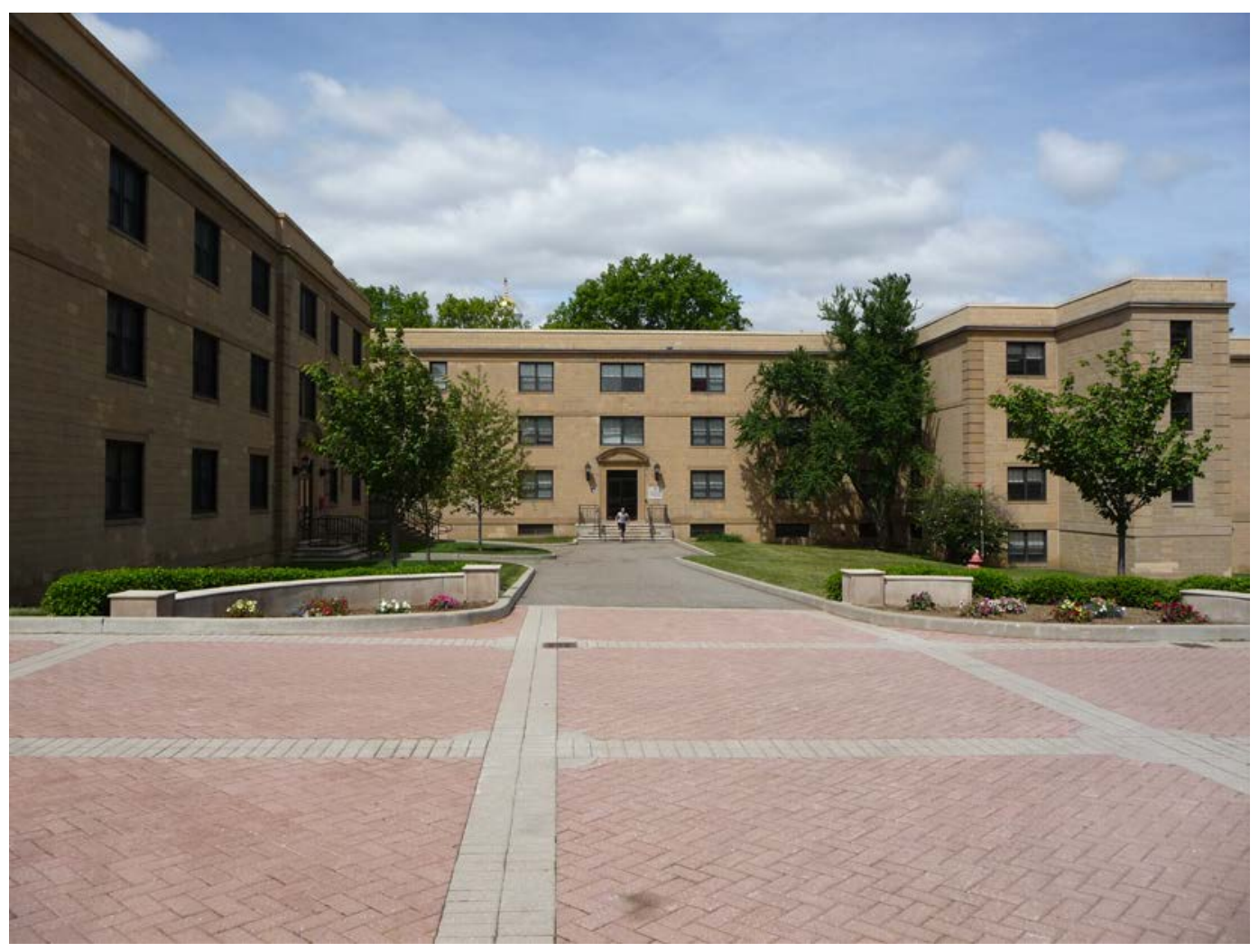




\subsubsection{Wiley Hall}

To the rear of Wiley Hall are the paved and grass terraces descending to the water with pergolas, retaining walls, a pool, and bathhouses (Figure 33-Figure 37). The plantings along the formal terraces are similar in style to what was present at the start of the Academy. Formal shrubs surround the bathhouses next to the pool (Figure 36 and Figure 37), and the WWII memorial and bell (Figure 38). The two pergolas are covered in wisteria vines (Figure 39).

Figure 33. Rear of Wiley Hall, 1942 (USMMA Bland Library).

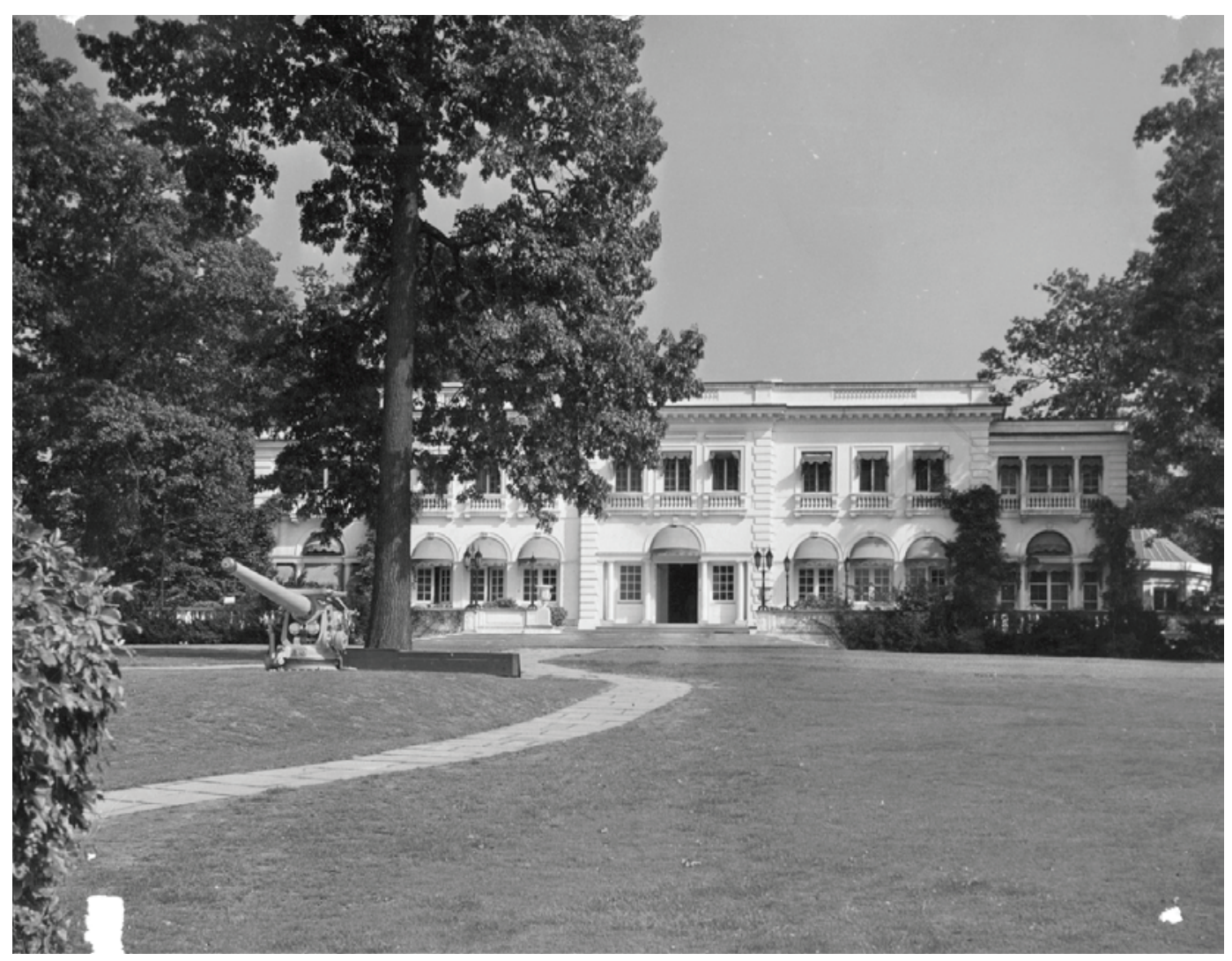


Figure 34. Vegetation at rear of Wiley Hall (ERDC-CERL, 2015).

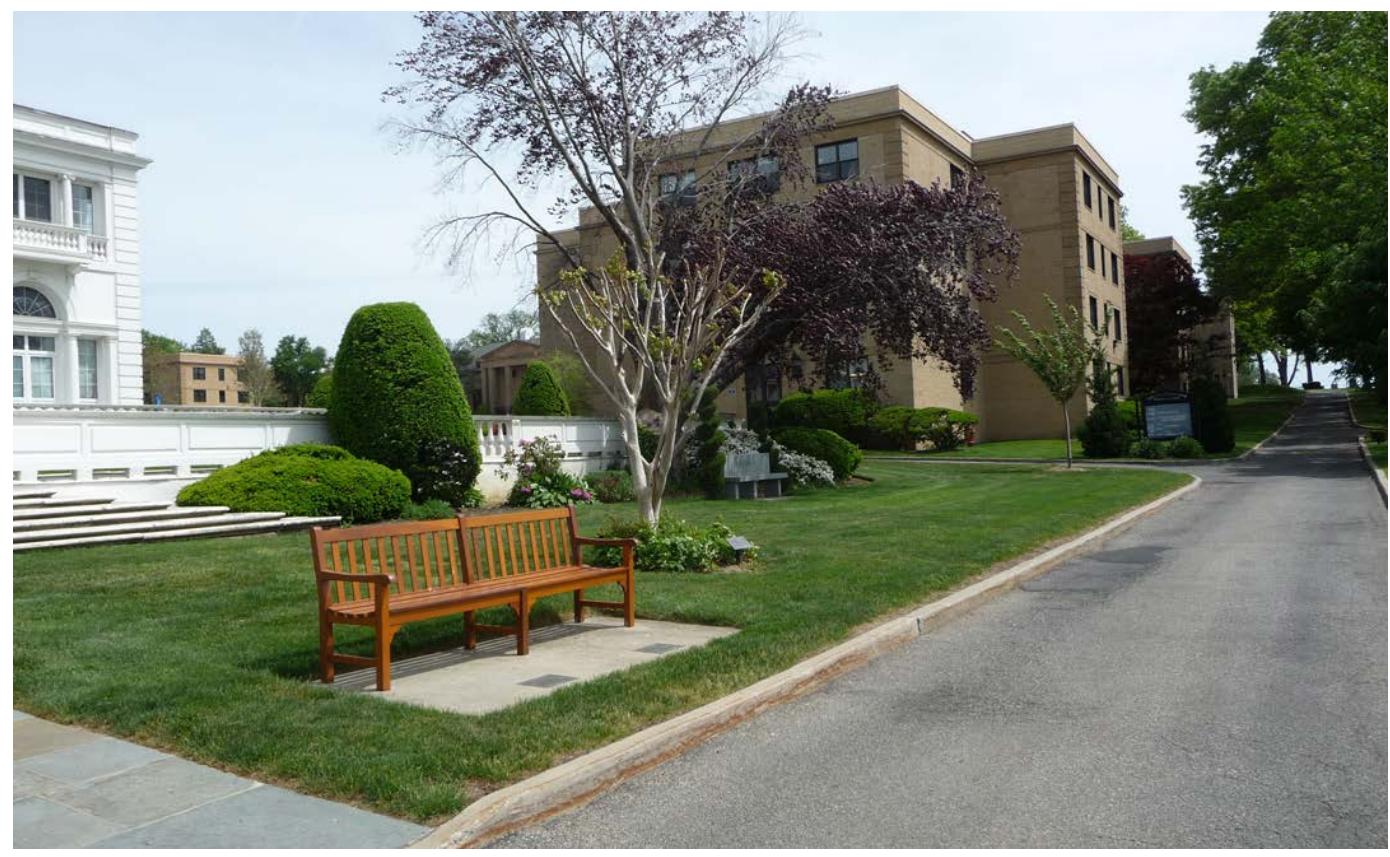

Figure 35. Plantings along terraces behind Wiley Hall (ERDC-CERL, 2015).

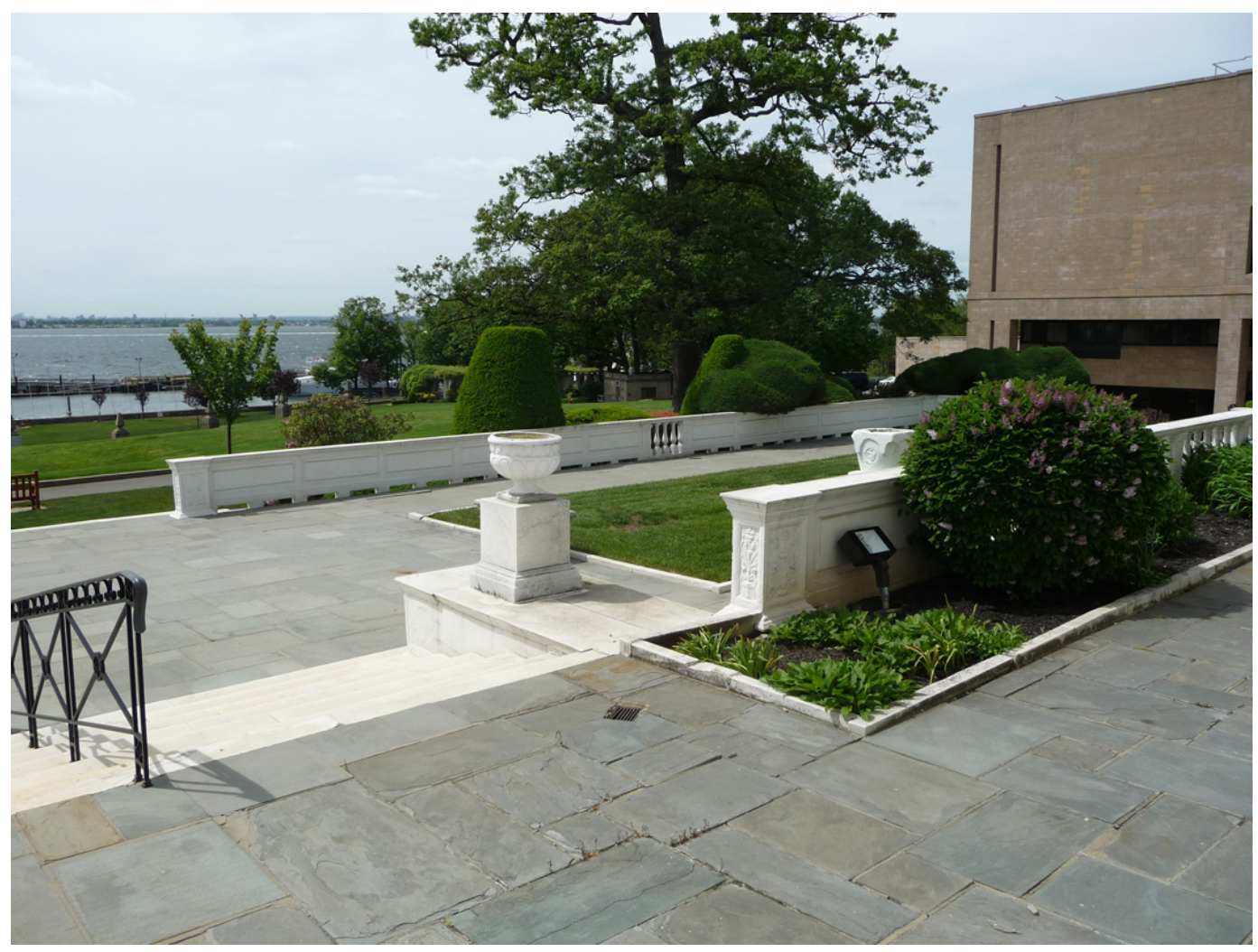


Figure 36. Vegetation surrounding bathhouse by pool, 1943 (USMMA Bland Library).

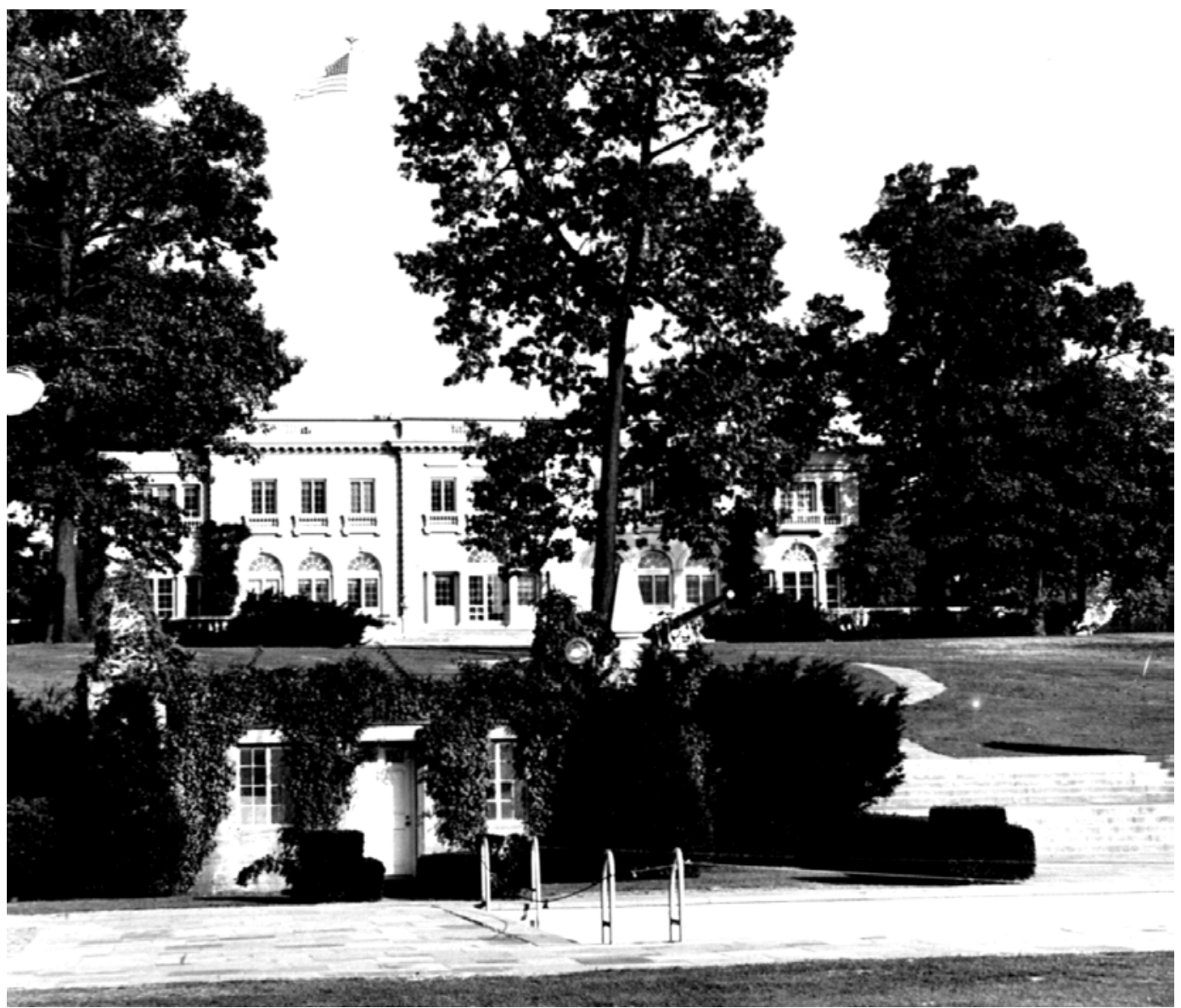

Figure 37. Vegetation surrounding bathhouse by pool (ERDC-CERL, 2015).

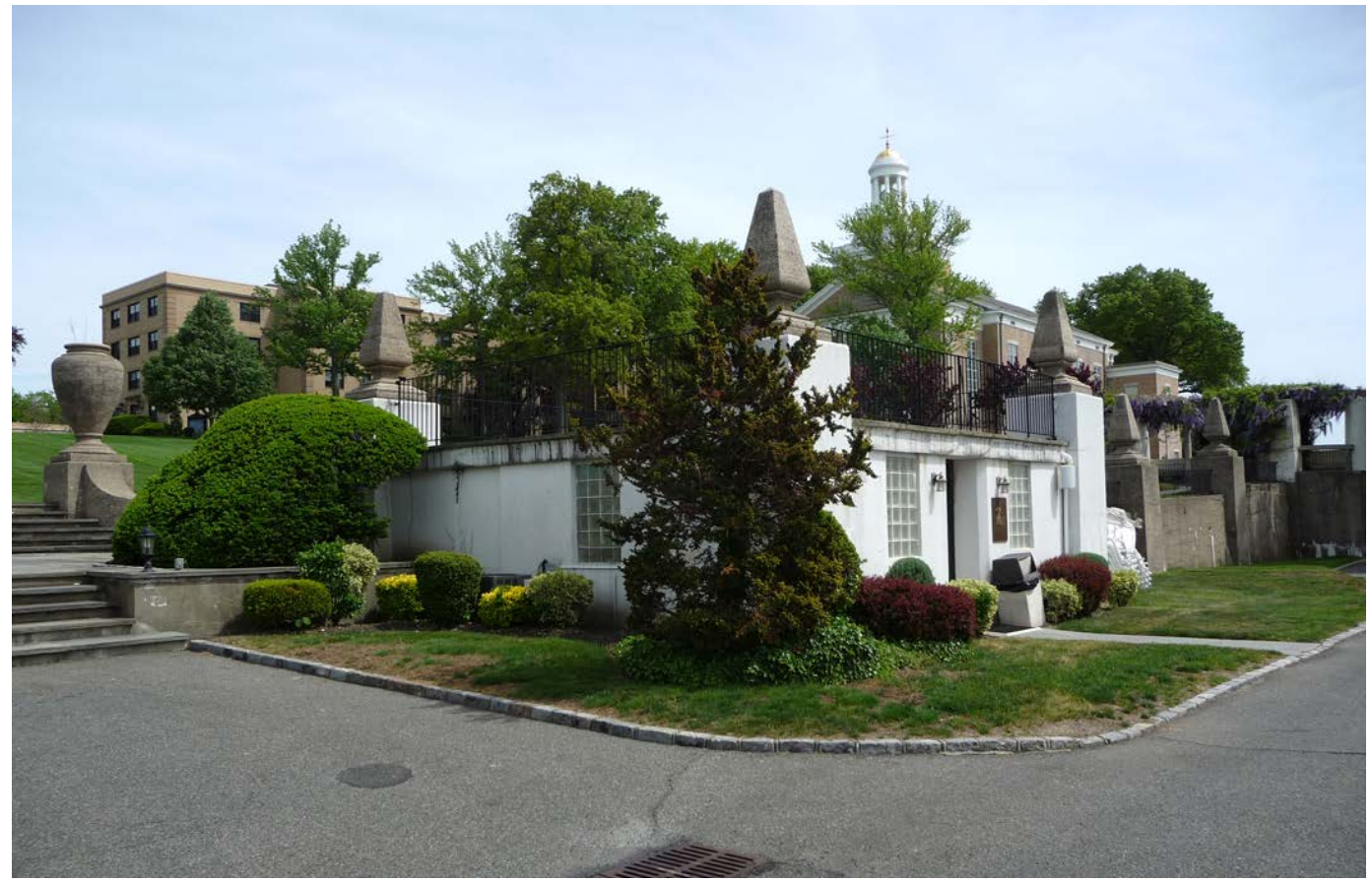


Figure 38. Formal shrubs surround the WWII Memorial and Bell (ERDC-CERL, 2015).

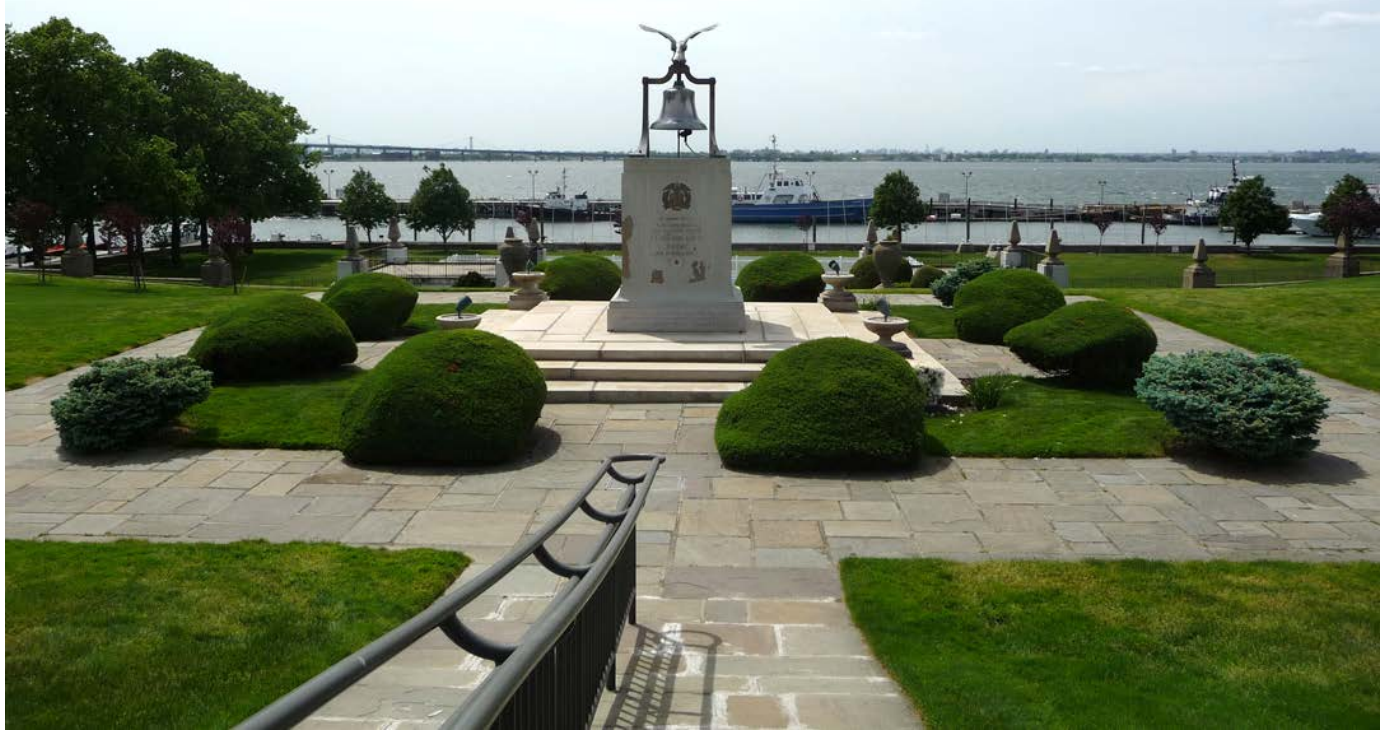

Figure 39. Pergola covered in wisteria vines (ERDC-CERL, 2015).

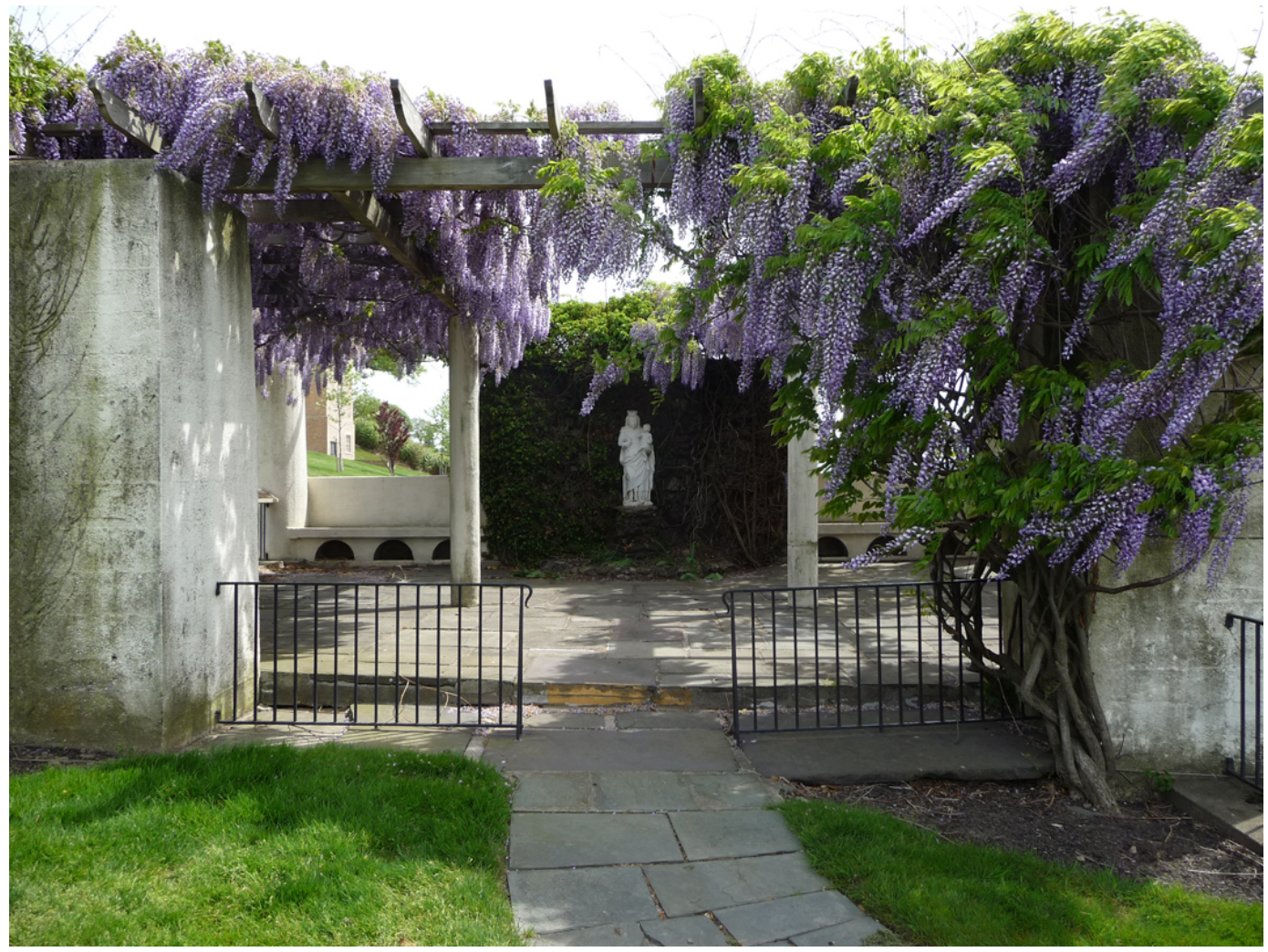




\subsubsection{Gardens of Gold Coast estates}

\subsection{Neiley estate}

The Neiley house was featured both in Architecture Magazine in 1915 ("House" 1915) and Arts and Decoration in 1919 ("At Home" 1919, 212213). The property contained the main house, garage with servants quarters (now Quarters J), and a greenhouse attached to the garage after 1919. The garage was greatly expanded between 1919 and 1943. There was a circular paved driveway with center plantings (Figure 40 and Figure 41) and a large formal garden south of the house.

The formal garden, typical of the Gold Coast estates, exists to the south of Patten Medical Clinic, although only in remnants. The garden, which is square in shape, appears to have had evergreens at the corners with a hedge along the outside edge (Figure 42). The interior of the garden was created by two intersecting paths, with beds near the center (Figure 43). Only a few beds and paths remain in this location today (Figure 44).

Figure 40. Entrance and drive to Neiley house, 1943 (USMMA Bland Library).

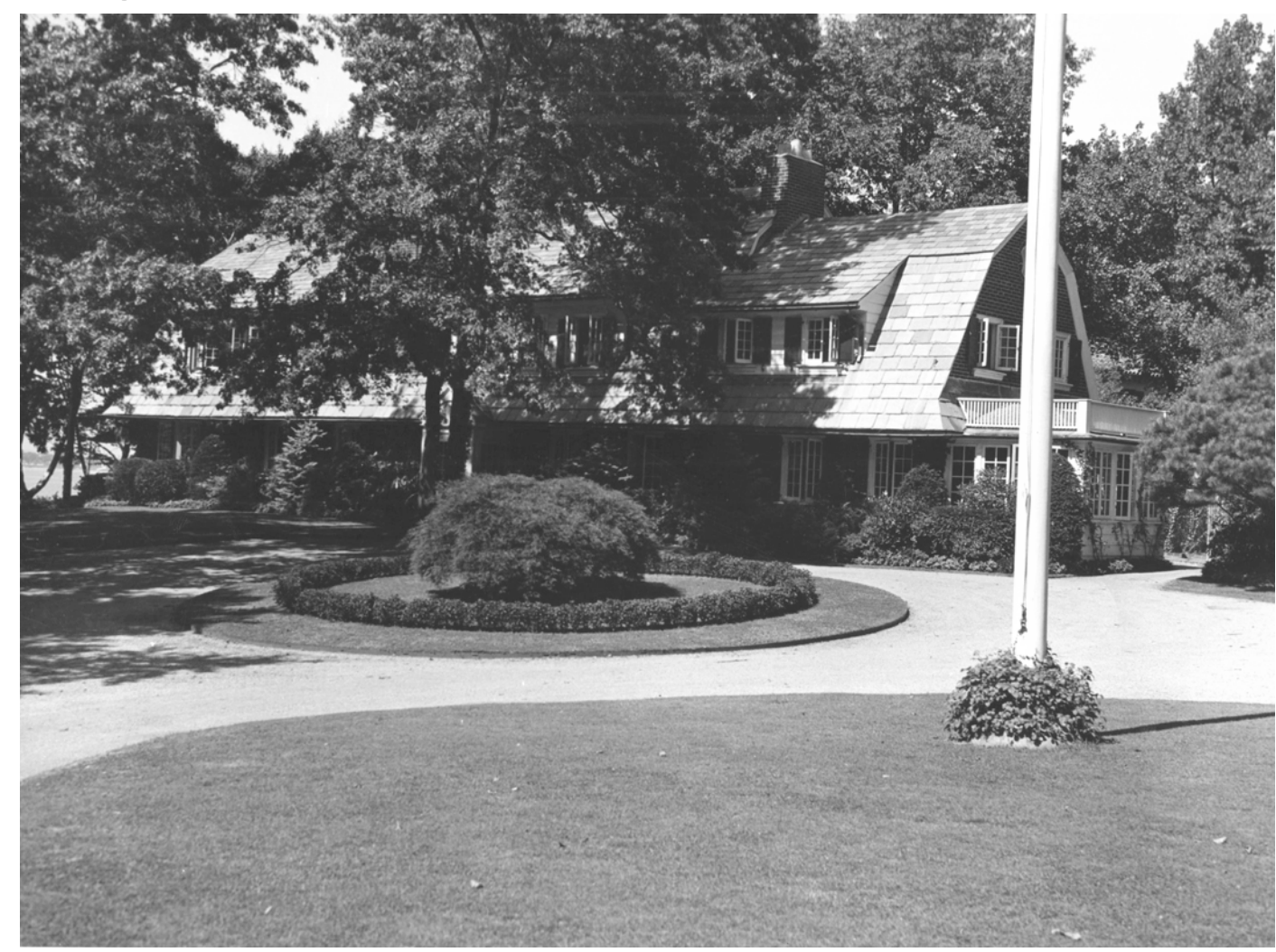


Figure 41. Entrance to Quarters A (Neiley house) (ERDC-CERL, 2015).

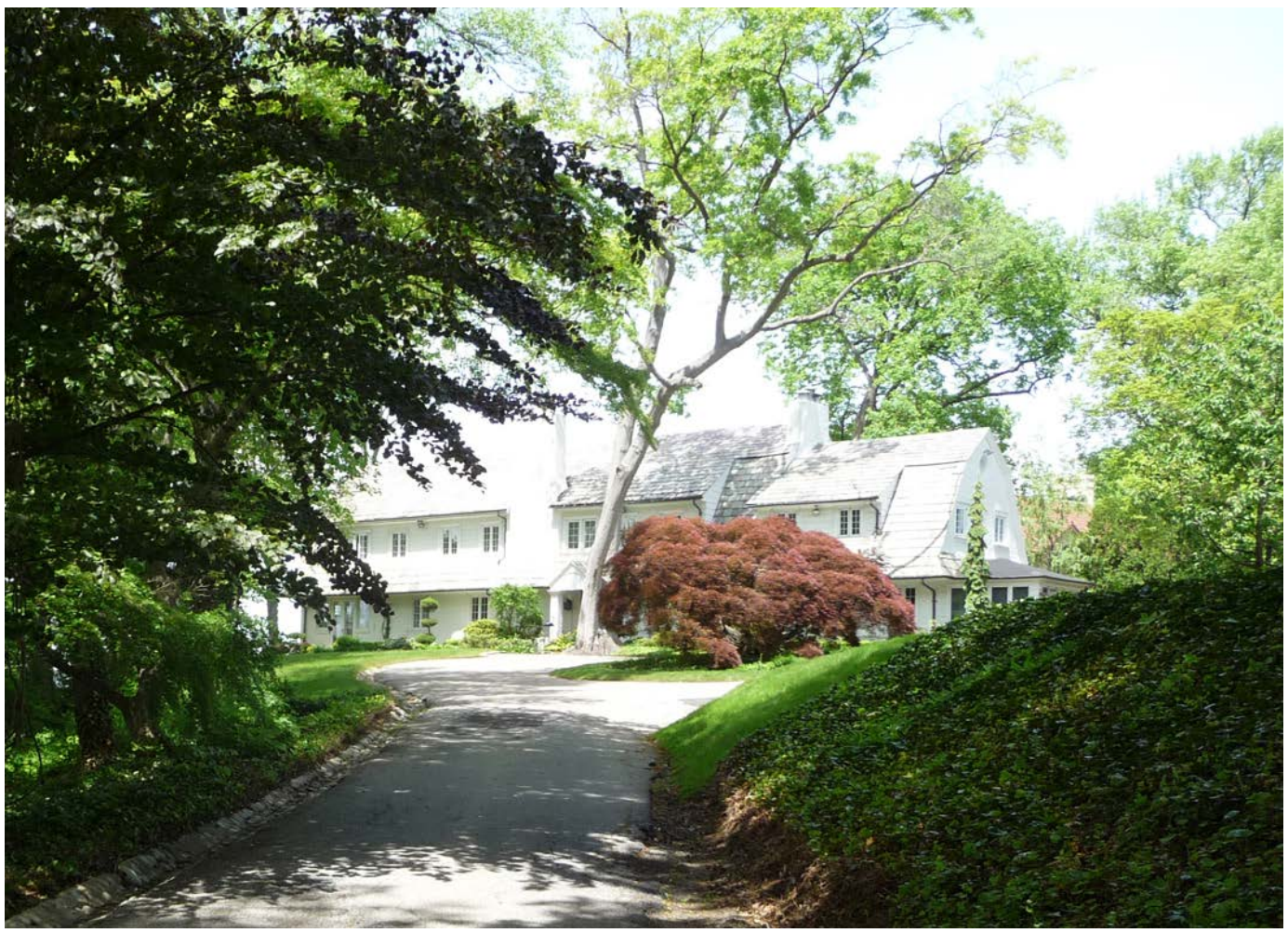

Figure 42. Formal garden (center foreground) located behind hospital, 1943 (USMMA Bland Library).

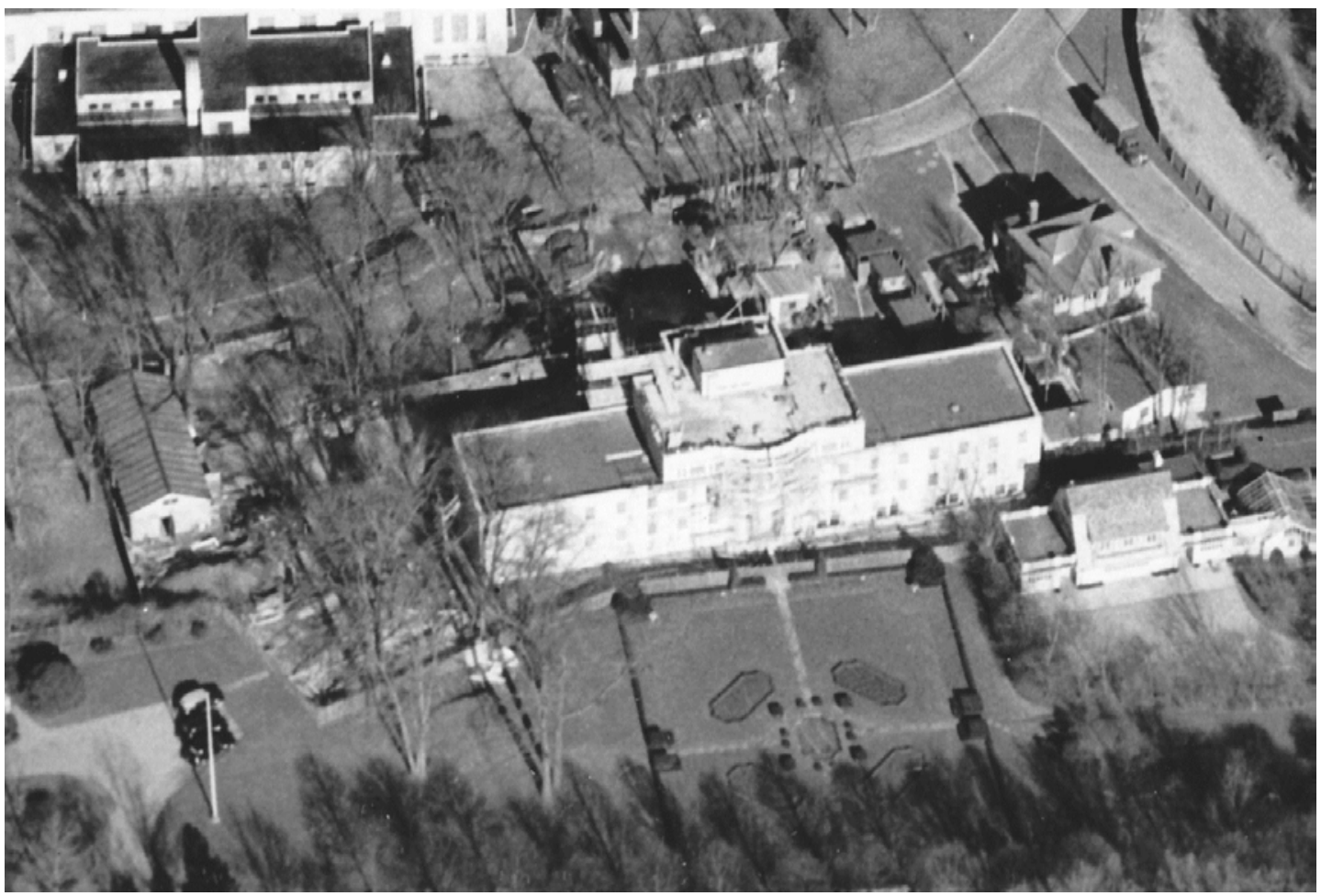


Figure 43. Formal garden located behind the hospital, as seen in yearbook photograph, 1944 (USMMA Bland Library).

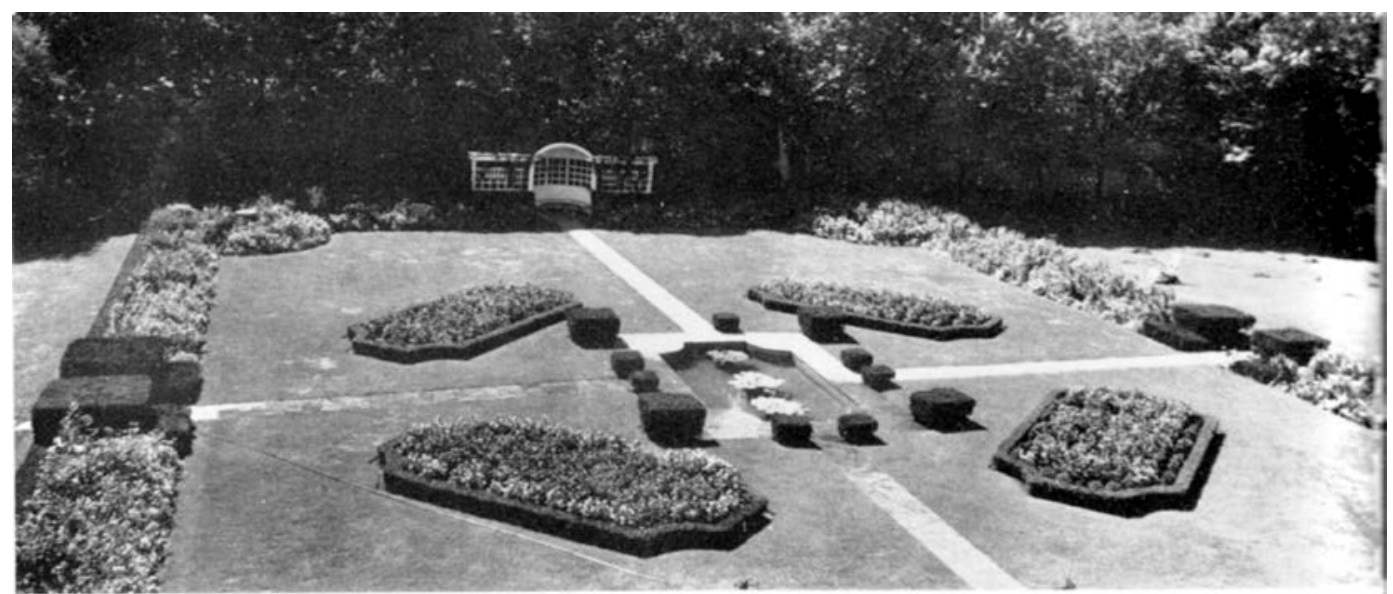

Figure 44. Garden behind Patten Medical Clinic (ERDC-CERL, 2015).

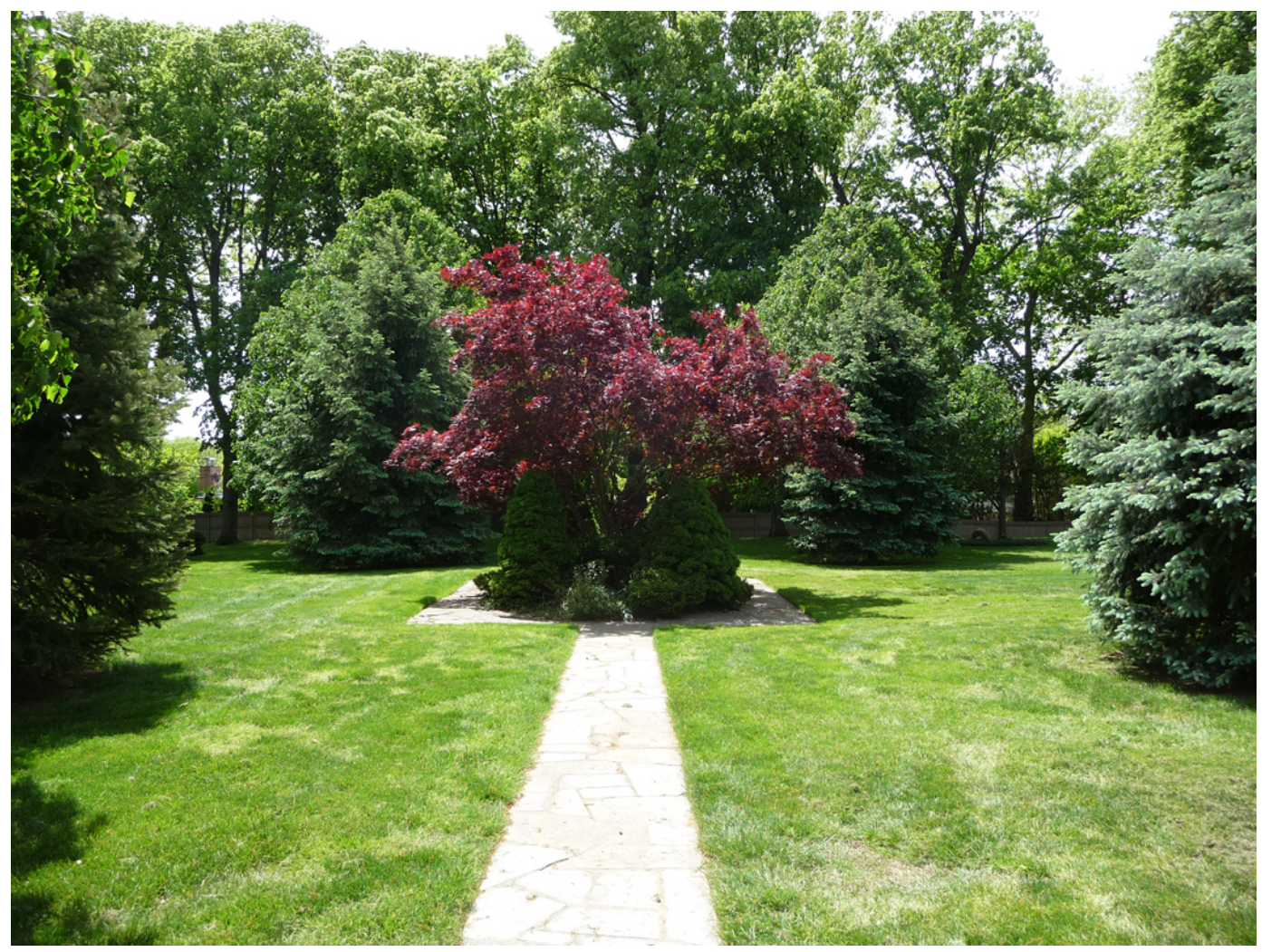

\subsection{Barstow mansion}

Formal gardens also existed at the Barstow Mansion, but today there are only remnants of these gardens. The grounds contained both formal gardens and a picturesque rock garden/folly. Formal gardens were placed southwest of the Barstow mansion, on what had been the Rosenberg property. They are visible in a 1943 aerial view of the estate, across the 
circular driveway (Figure 45). The gardens were three connected parterres, each rectangular in shape and delineated with hedges (Figure 46). The first parterre was closest to the residence, and it contained a fountain in the center and stone or gravel paths between the four beds. The paths were lined with hedges with accent evergreens on each side of the four entrances to the garden. Within each of the four rectangular beds was a central circular bed, which may have contained sculptures or urns, and a row bed on either side of each circular bed, surrounded by lawn. The fountain, in poor shape and used as a planter, and portions of the stone paths lined with yew shrubs are all that remain today of this parterre (Figure 47).

Figure 45. Aerial showing Barstow gardens (center) with the mansion (lower left), 1943 (USMMA Bland Library). [Note that the formal garden at the top right was part of the Schebera gardens.]

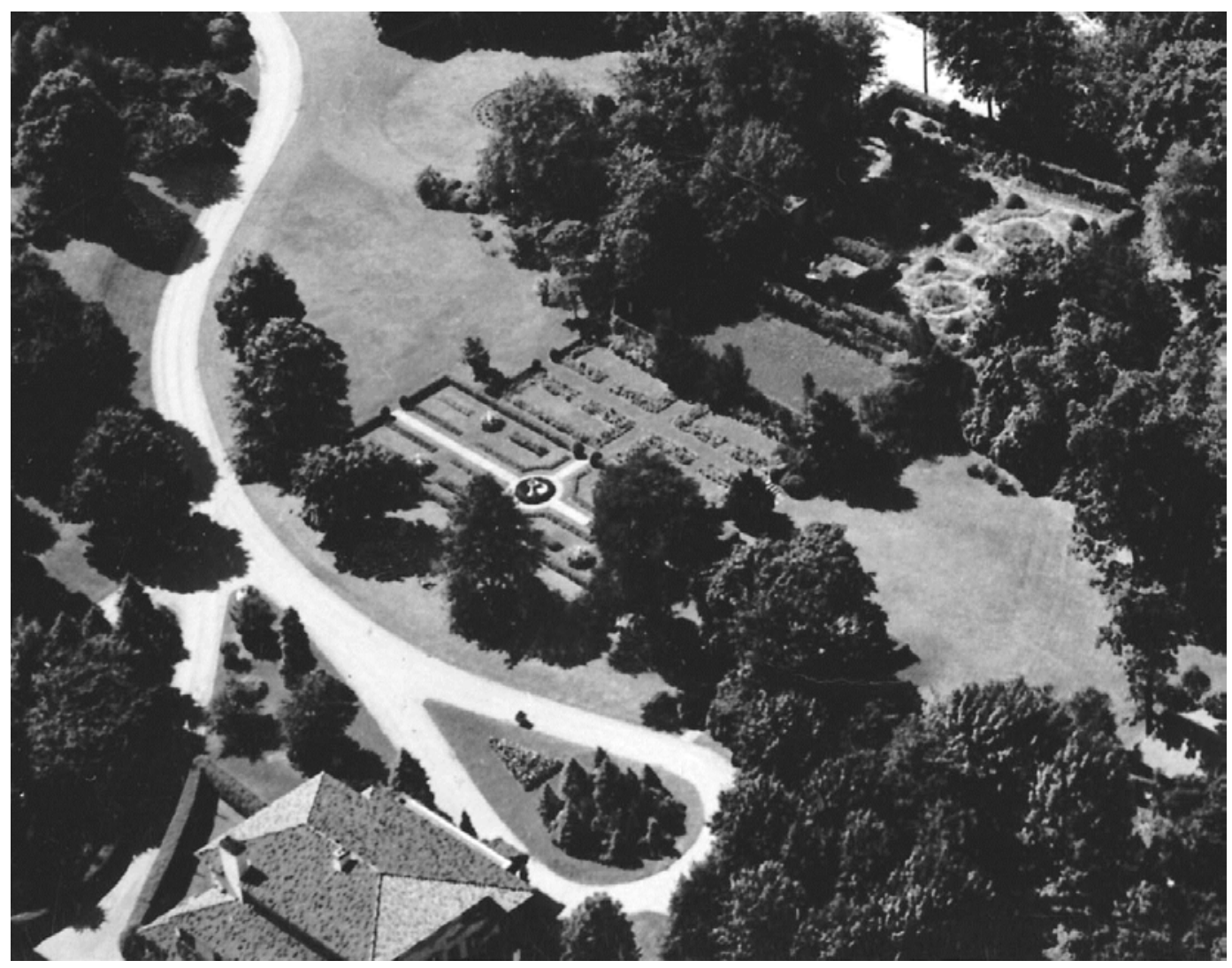


Figure 46. Aerial view of the Barstow gardens (center), 1943 (USMMA Bland Library). The Schebera Estate along Steamboat Road is visible near bottom far right of photograph, along with its associated formal gardens.

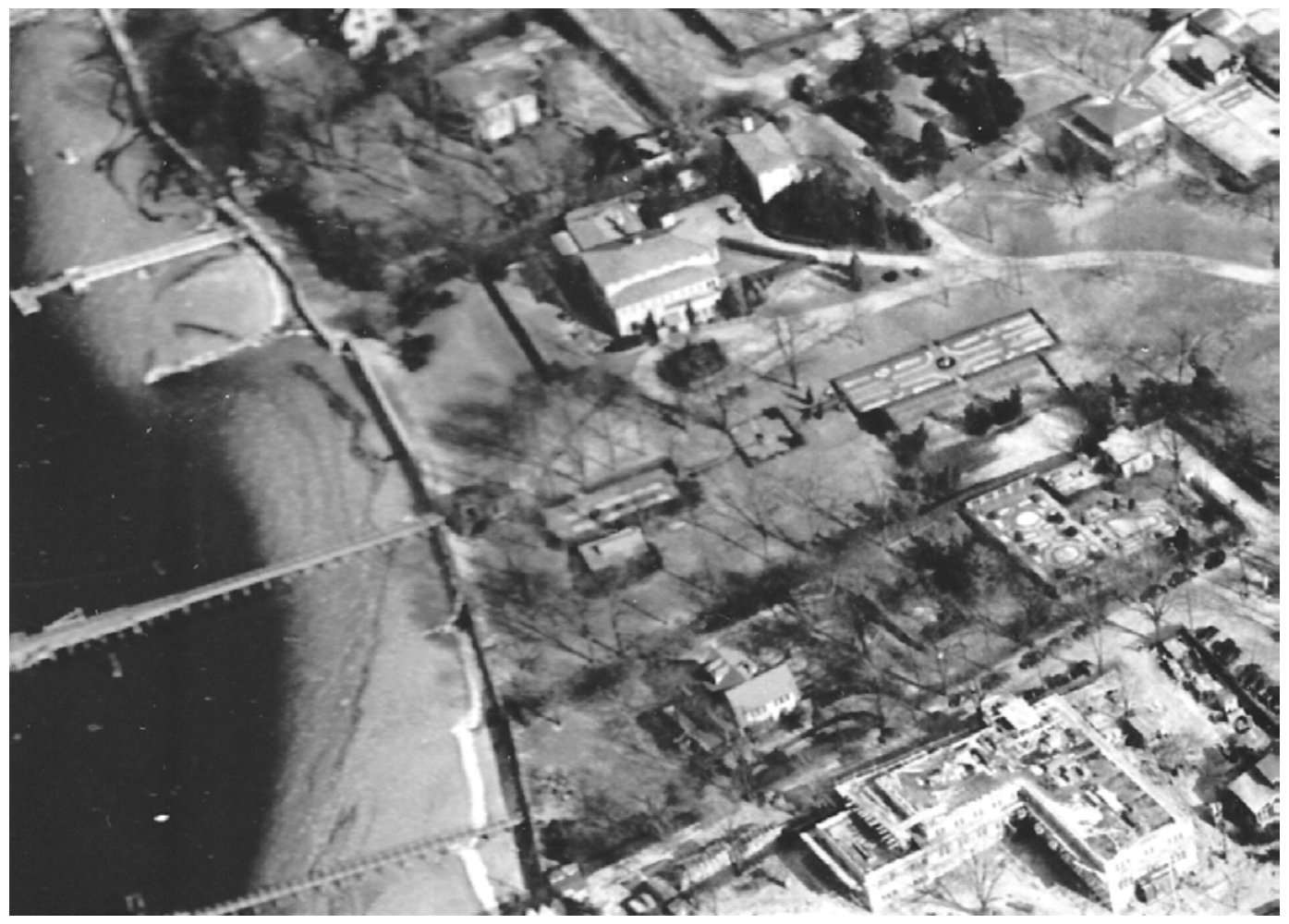

Figure 47. Remnants of Barstow Estate formal gardens, with gun monument in rear (ERDC-CERL, 2015).

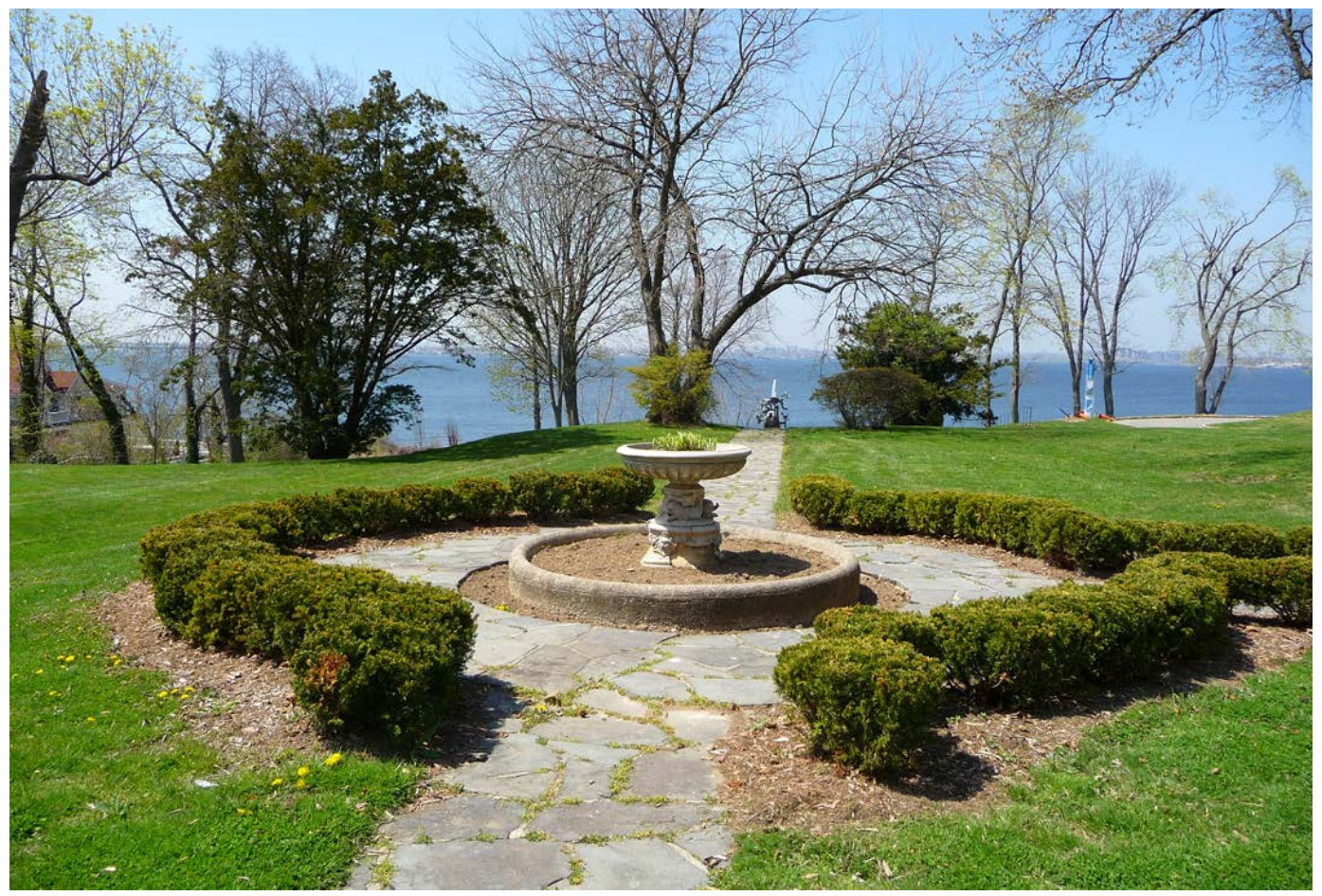


The second parterre was smaller in size than the first. Also divided into four rectangular gardens, this parterre used rose beds as hedges, and the paths and rectangular gardens were lawn. Evergreen hedges defined the opposite ends of the parterre, and stone steps were located at the northwest end. The third parterre was a rectangular lawn area with heavily planted borders of trees and shrubs and possibly a wall or fence along the northeast and southeast sides. An entrance to this parterre, on axis with the paths from the other two parterres, existed between large evergreens along the northeast side. Another, wider entrance is visible in the aerial along the northwest side, connecting the garden and the yard to the water (see Figure 46). There are no remnants of these two parterres today.

In addition, two more formal gardens existed on terraces northwest of and on axis with the fountain and paths in the first parterre. The fourth parterre, square in shape, also contained paths, a central circular focal point, and evergreen hedges delineating the garden. Today there are remnant stone paths, the same material of those remaining from the first parterre, at the site of the fourth garden. While today a gun monument occupies the focus area (see Figure 47), it is unknown what was in this location during the Barstow ownership. Currently, the path and stairs lead from the driveway around the monument and dead end in the lawn. The aerial from 1943 above (see Figure 45) shows evergreen-lined paths connecting these terraced gardens. A fifth parterre, rectangular in shape and further to the northwest, existed northeast of the tea/summer house. Surrounded by an evergreen hedge, double rows of beds are visible in the aerial. This garden also connected to the boat house and dock at the water's edge. Only a white pedestal, possibly that of a birdbath, remains in this area. The rock garden/folly was put in place on a sloping piece of land about one-third of the way from the driveway gates. Judging from the current appearance (Figure 48), the rock garden was meant to resemble a highland stream, with a jumble of small boulders coursing down the slope in a naturalistic manner. A waterfall ran from the top to a pool at the bottom. There was a structure at the top of the rock garden, probably a pergola for shade. The area currently contains evergreen plantings, and the overall effect must have been a semi-concealed feature that provided a place for escape and contemplation.

Foundation plantings have always existed around the mansion's foundation. Historically, there were vines climbing the house, and mature evergreens outside the breakfast room (Figure 49). Today there are no 
vines, and the vegetation is in keeping with the size and scale of the house (Figure 50).

Figure 48. Barstow rock garden/folly (ERDC-CERL, 2015).

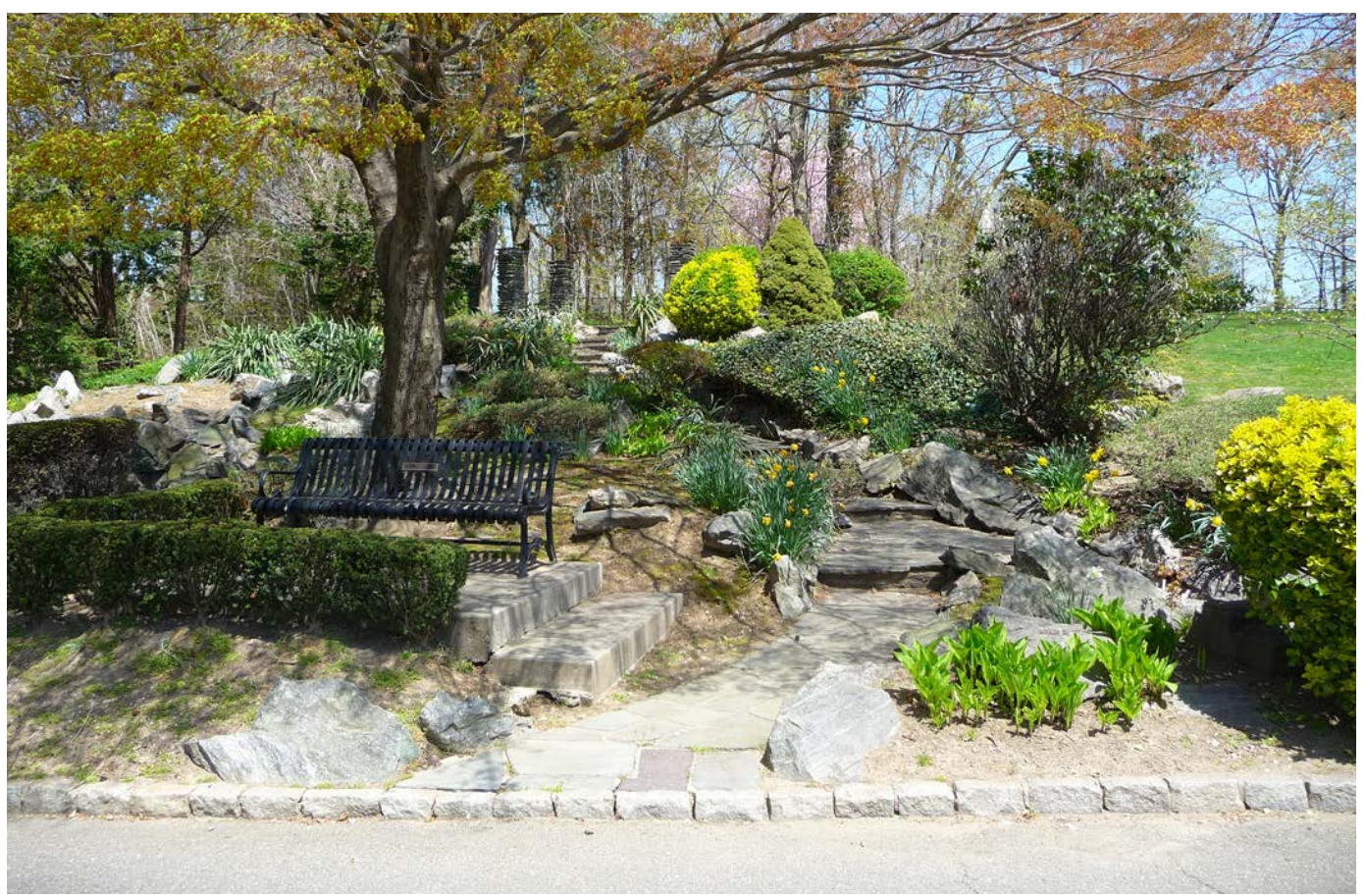

Figure 49. Real estate sales brochure for Barstow estate showing heavy foundation plantings around mansion, c. 1960 (Morgan Guarantee Trust).

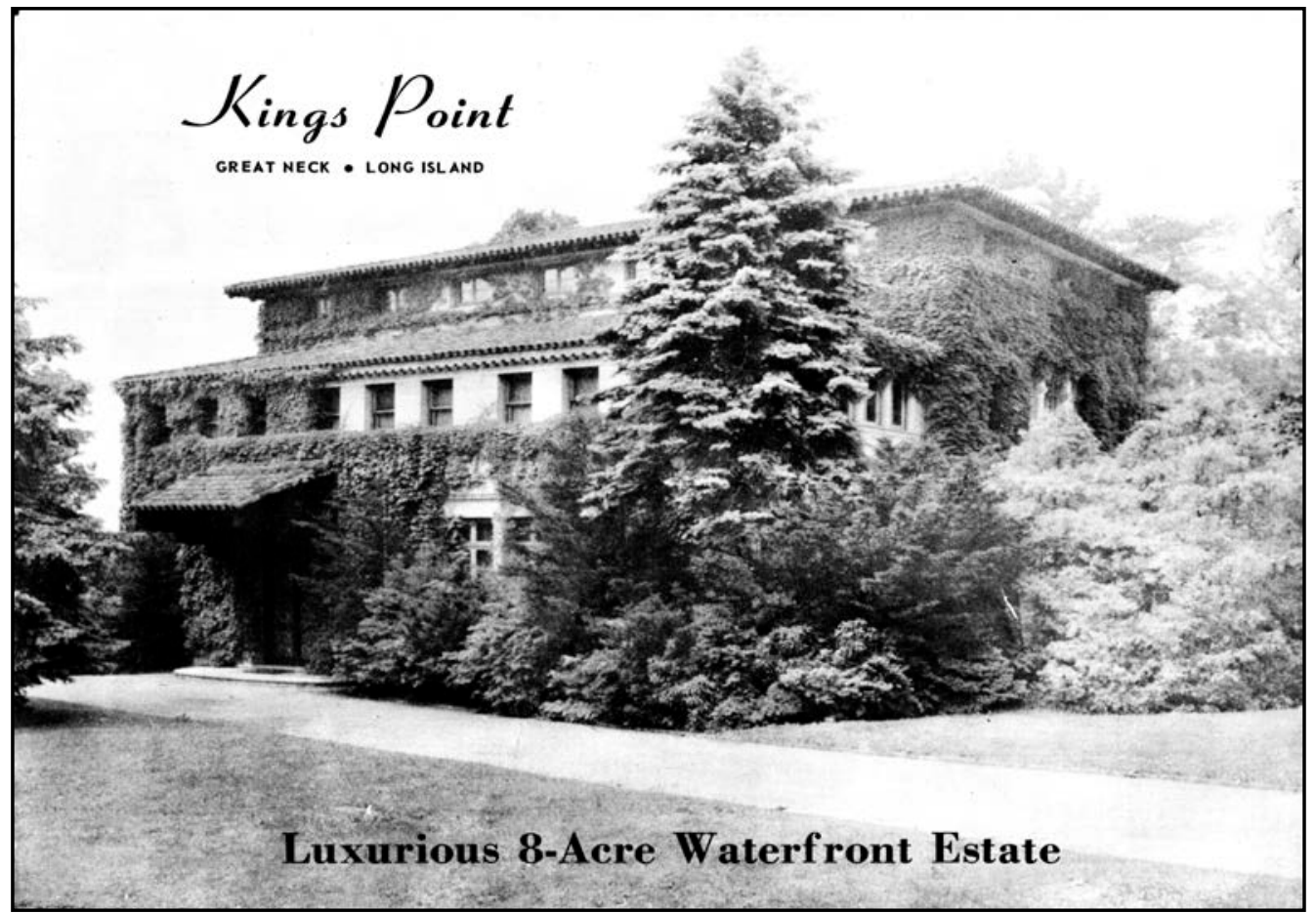


Figure 50. Vegetation around foundation of Barstow mansion (currently the American Merchant Marine Museum; ERDC-CERL, 2013).

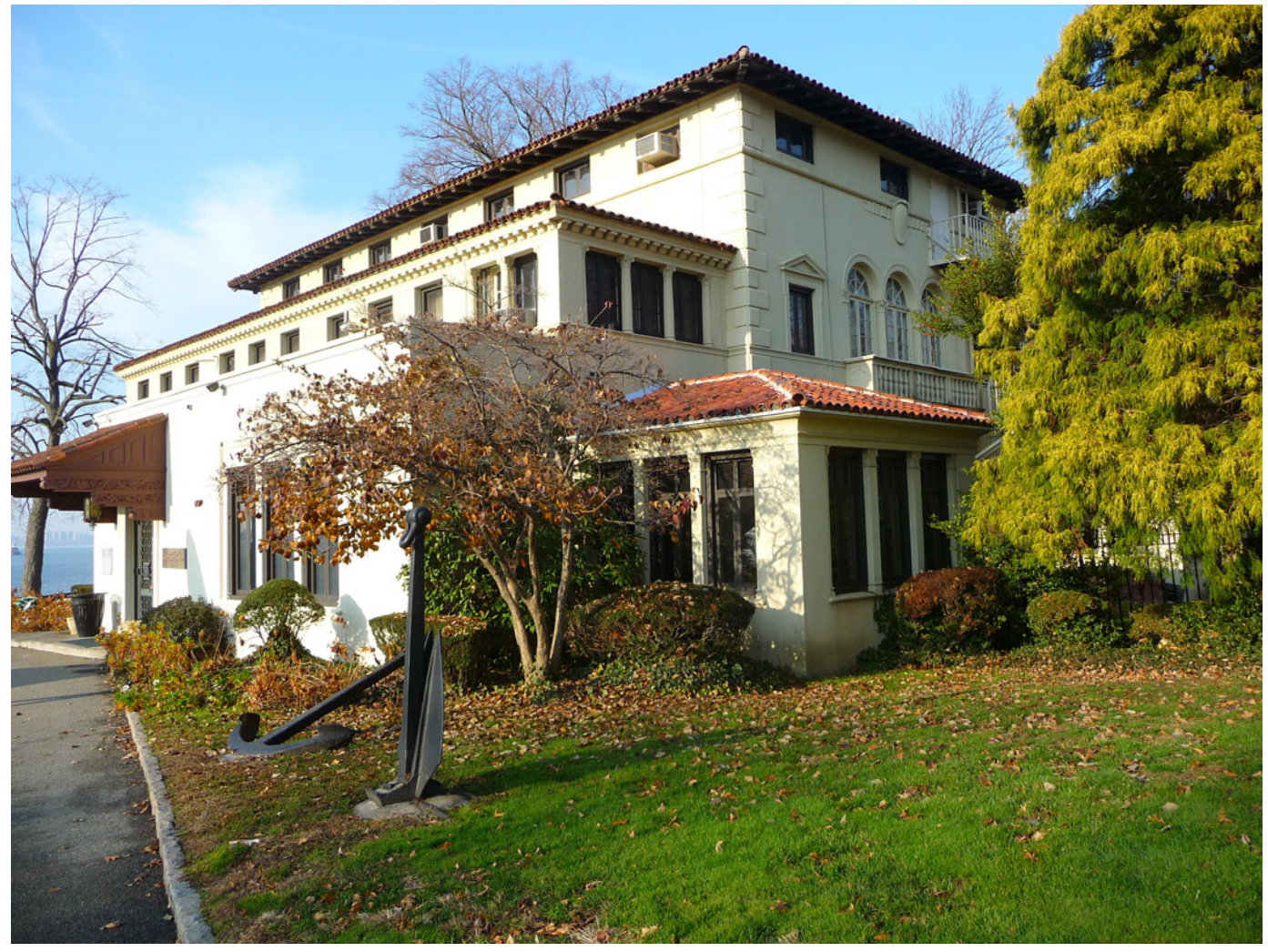

\subsection{Schenck Estate}

When the Schenck estate was purchased by the government, there were six buildings on the property. Schenck had recently acquired the house (Figure 51) belonging to his neighbor, W.S. Houston. In addition to the two houses, the estate contained four other structures: (1) a theater, (2) garage/quarters with connected greenhouse, (3) a small cottage, and (4) another garage/quarters with connected greenhouse. There was a small, designed garden to the south of the Schenk house, with a circular feature. There was also a large circular parking area on the north side just past a porte cochere, which were removed during construction of the Academy (Figure 52). Today the gardens are gone, but the house has foundation plantings (Figure 53). 
Figure 51. View looking north at former Houston house and garden, with Chrysler rose garden at lower right (house and garden later demolished), undated

(Mackay et al. 1970).

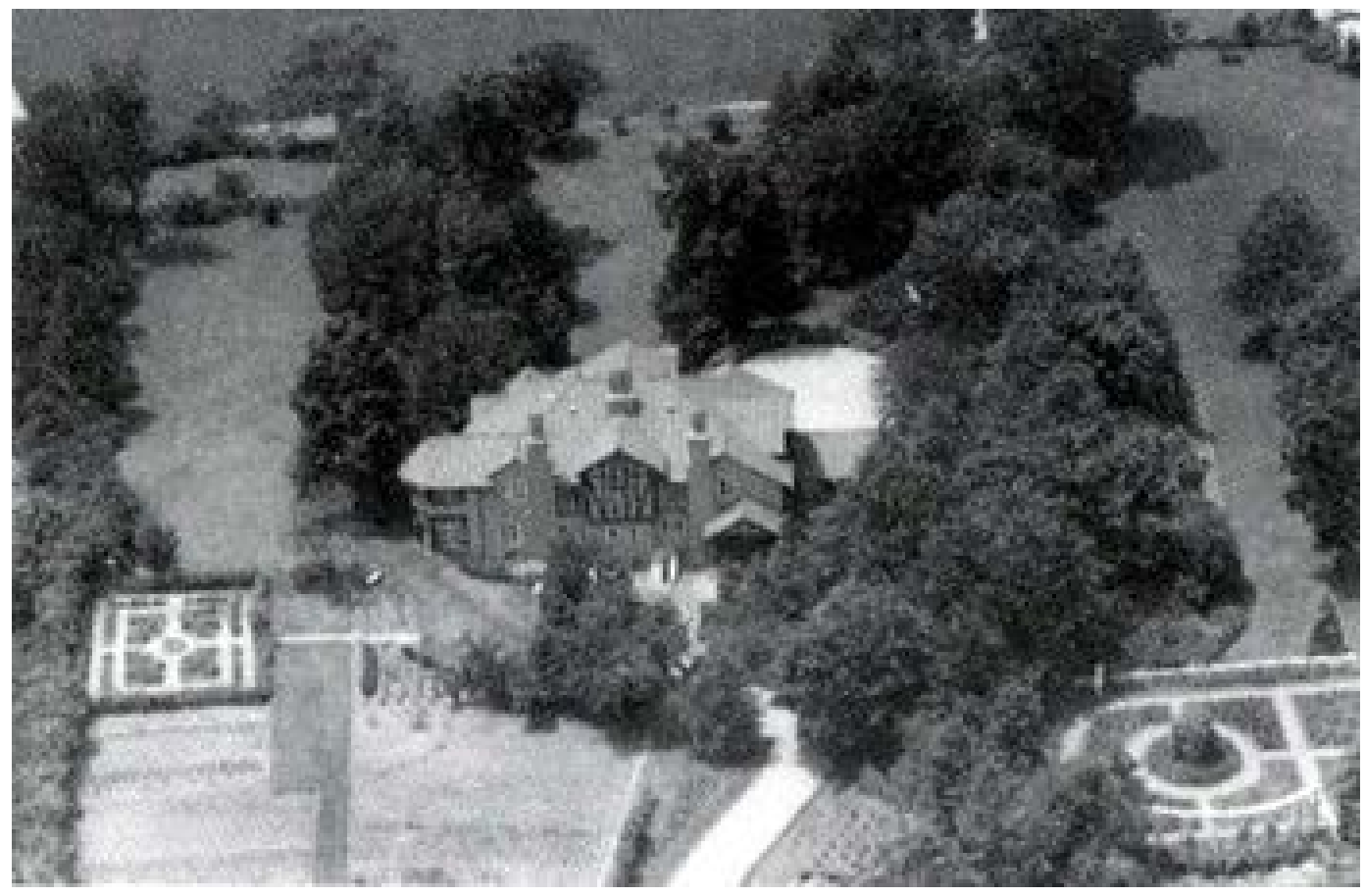

Figure 52. Schenck house (Land Hall), north facade, 1942 (NARA).

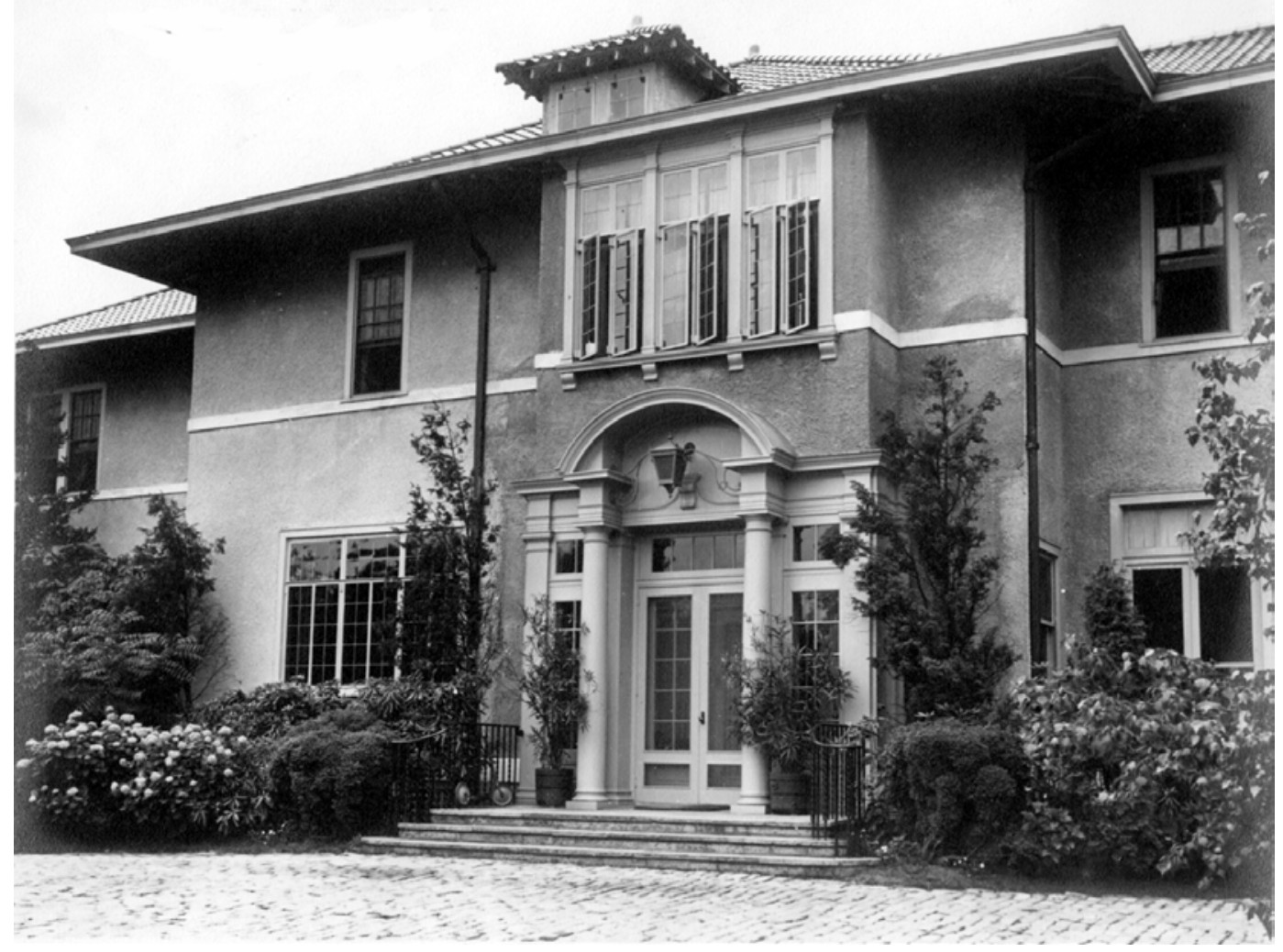


Figure 53. Schenck house (Land Hall), north facade (ERDC-CERL, 2015).

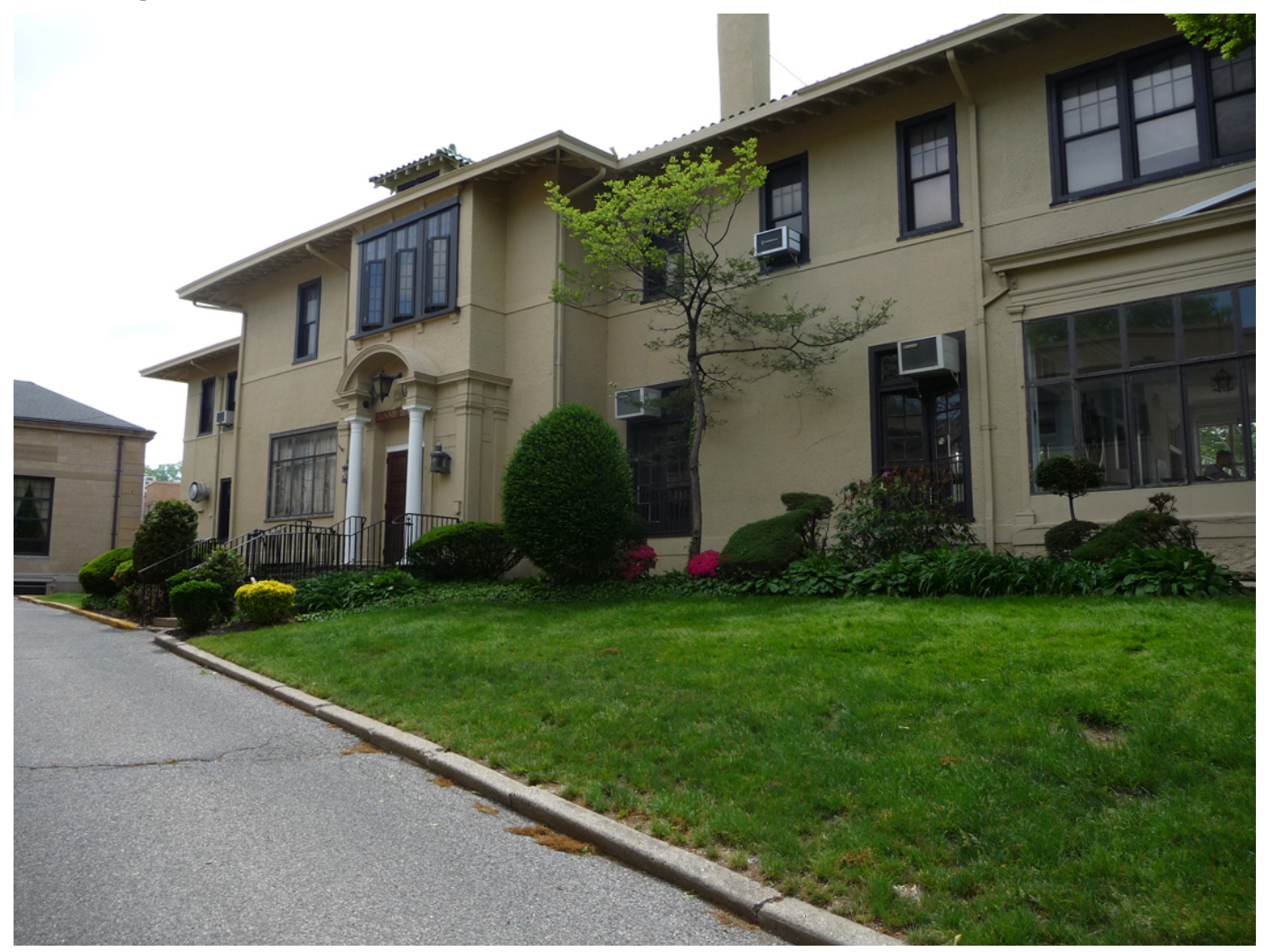

\subsection{Meighan estate}

In addition the Meighan house (now Melville Hall), the estate's property included a garage (now Quarters K), servants' quarters, and a greenhouse. The lot was wooded, with a steep slope to the water's edge. A small, formal garden was located south of the main house, and there was also an English-style garden, gone today. The entrance and the front of the house, as well as the rear, had foundation plantings (Figure 54-Figure 56). Today, there is a new addition in the rear, but the front maintains its foundation plantings (Figure 57). 
Figure 54. Front facade of Meighan house, date unknown (USMMA Bland Library)

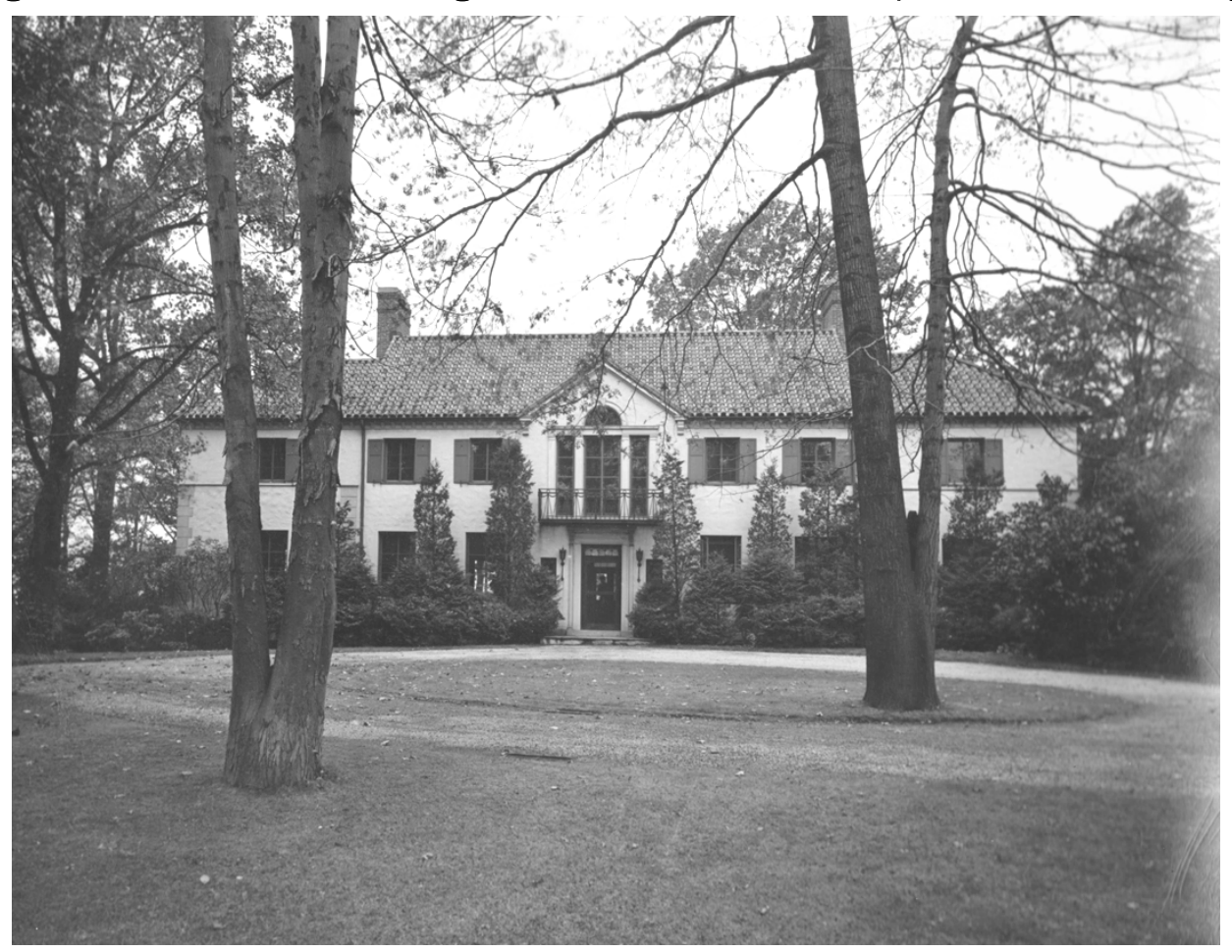

Figure 55. Rear of Meighan house, 1965 (USMMA Bland Library).

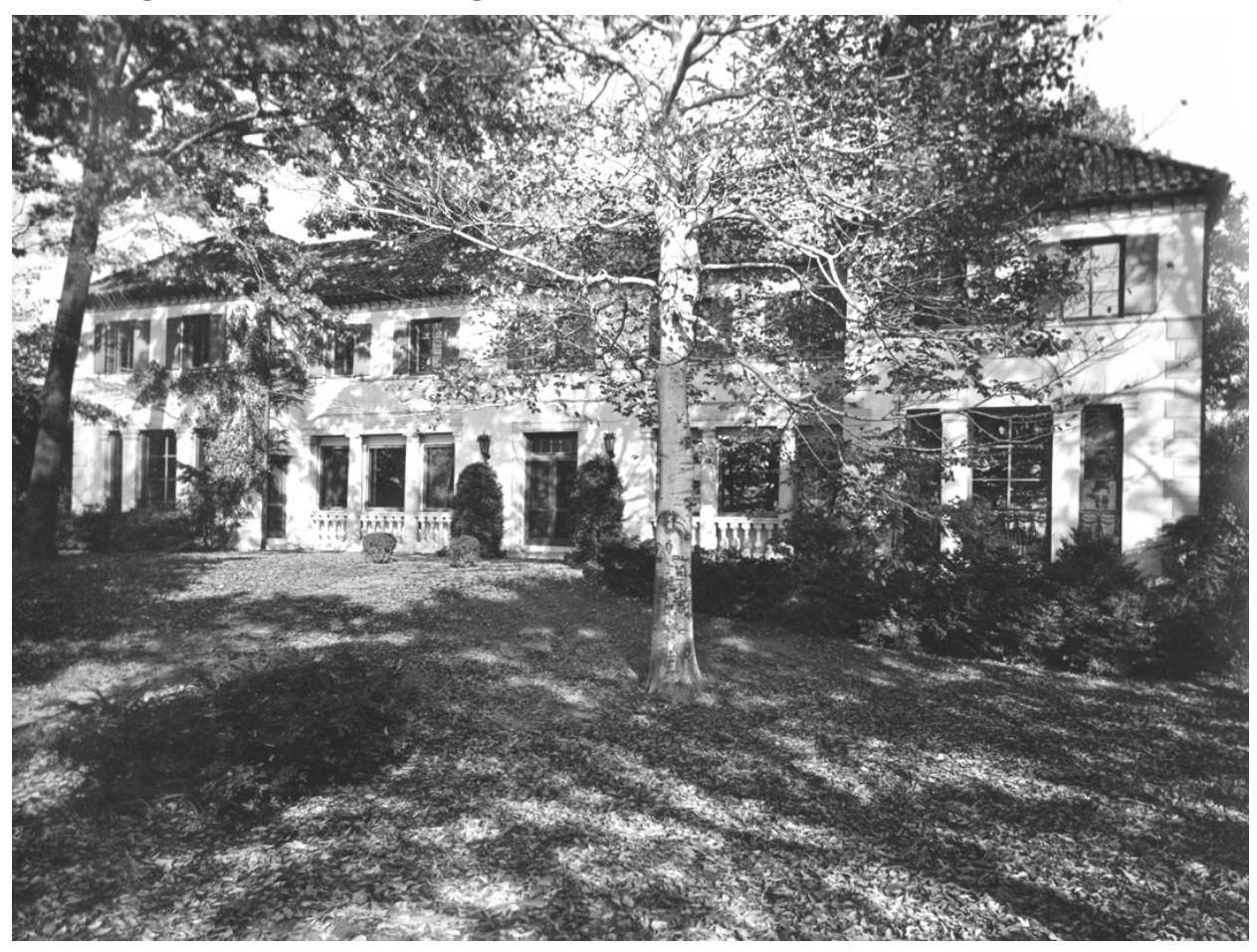


Figure 56. Front facade of Meighan house, after replacement of foundation plantings, 1967 (USMMA Bland Library).

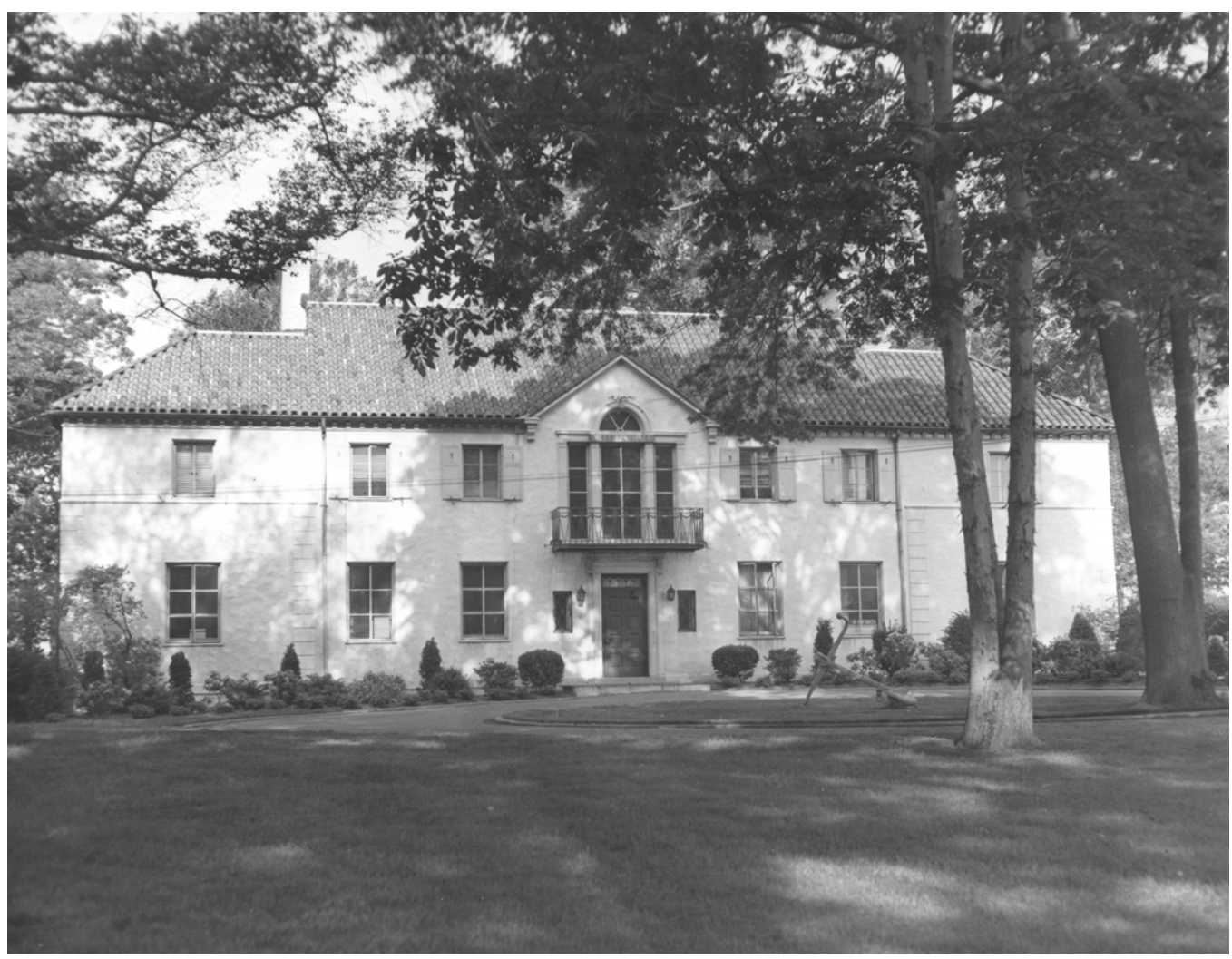

Figure 57. Foundation plantings along front facade of Melville Hall (ERDC-CERL, 2015).

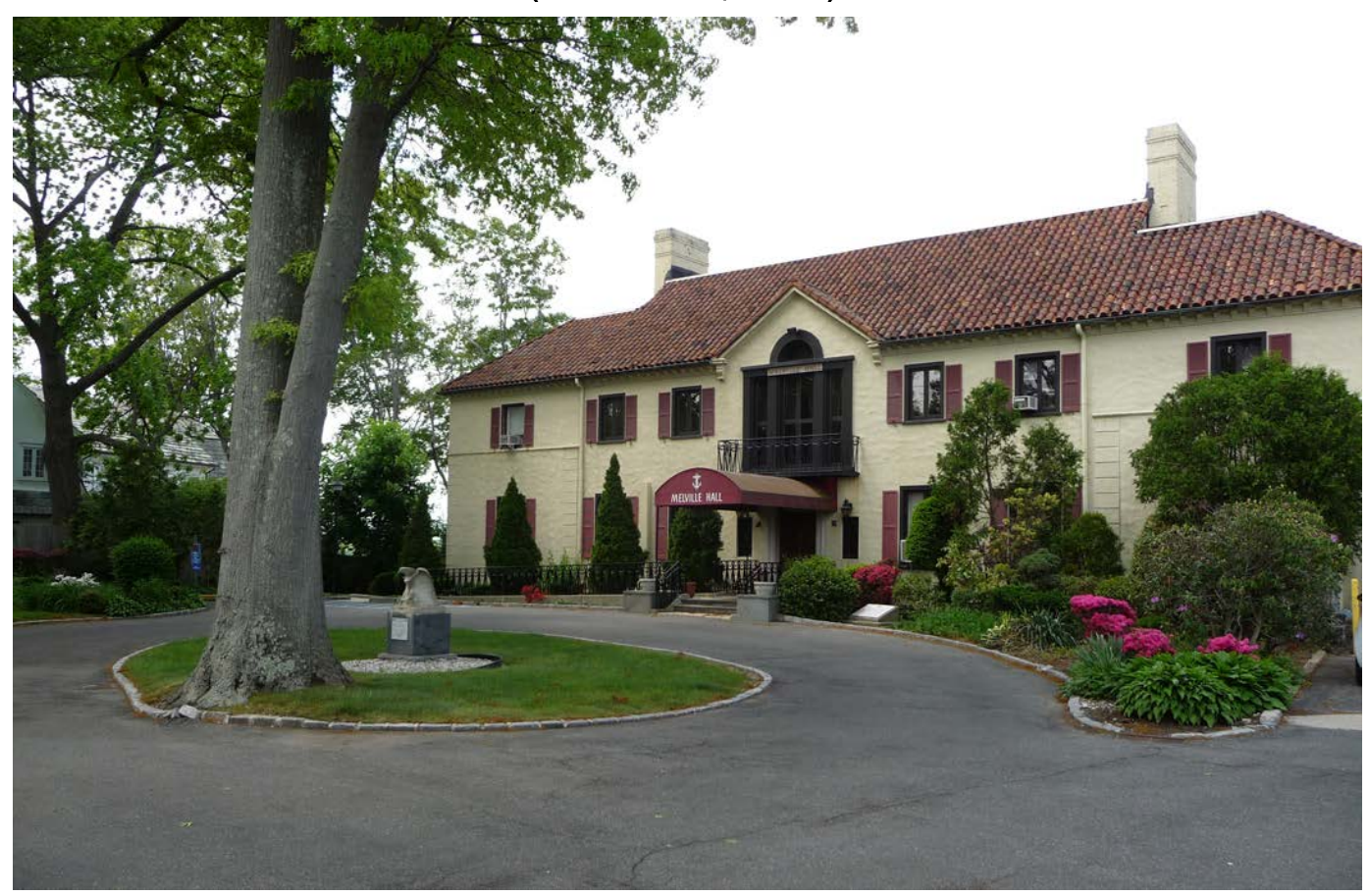




\subsubsection{Small-scale features}

In addition to other features in the landscape, many small-scale features exist around the Academy and its quadrangle, reflecting the commemorative culture of the military and the merchant marine. The recognition of historic events, fallen heroes, and persons integral in the establishment of the Academy is seen in the numerous monuments, plaques, and maritime artifacts strategically placed throughout the landscape. Every plaza, portico, building, and terrace has been dedicated to a person(s) of importance to the history of the Academy, with many of these dedications made in recent years. While the plaques and monuments may not be contributing to the Historic District due to not being added until after the periods of significance, it is noted that the collective presence of these features does contribute to the association and feeling of the Academy.

\subsubsection{Amphitrite Pool}

The Amphitrite Pool is located in the heart of campus. The pool's fountain was constructed after Walter P. Chrysler purchased the Henri Bendel estate. The fountain was most likely designed in 1929 by the New York landscape architecture firm of Charles W. Leavitt \& Sons. Amphitrite, the Greek goddess of the sea and wife of Poseidon, is holding an urn on her left shoulder (Figure 58). A shell lies at her feet in the pool, and four frogs on pedestals are arranged around her. To the west of the Amphitrite Pool is the Academy's flagpole. The Amphitrite pool and the flagpole are on axis with the front door and gardens in front of Wiley Hall. Contributing flower beds and a flagstone walkway encircle the pool's basin (Figure 59). 
Figure 58. Amphitrite pool, 1942 (USMMA Bland Library).

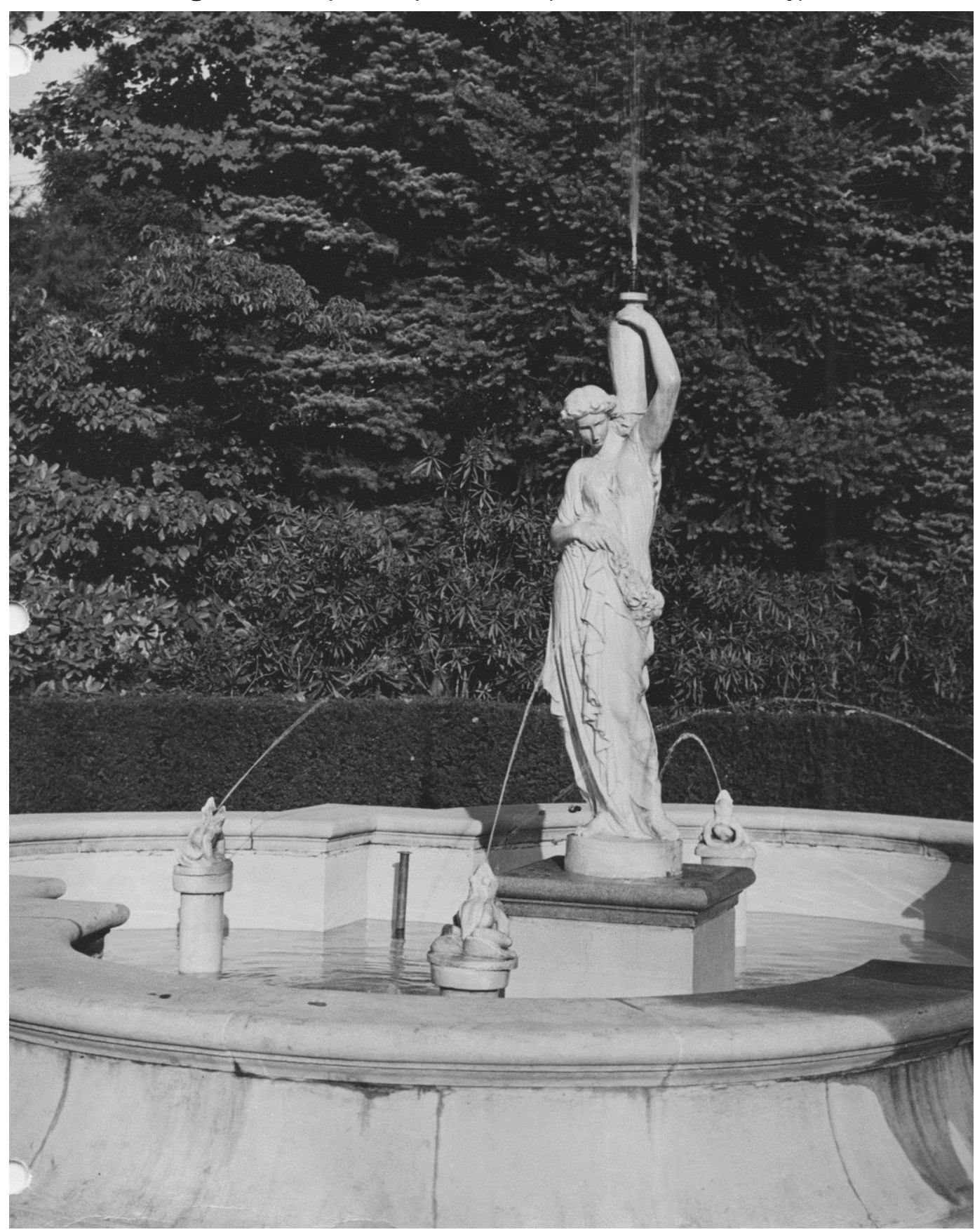


Figure 59. Amphitrite Pool with the flagpole behind (ERDC-CERL, 2015).

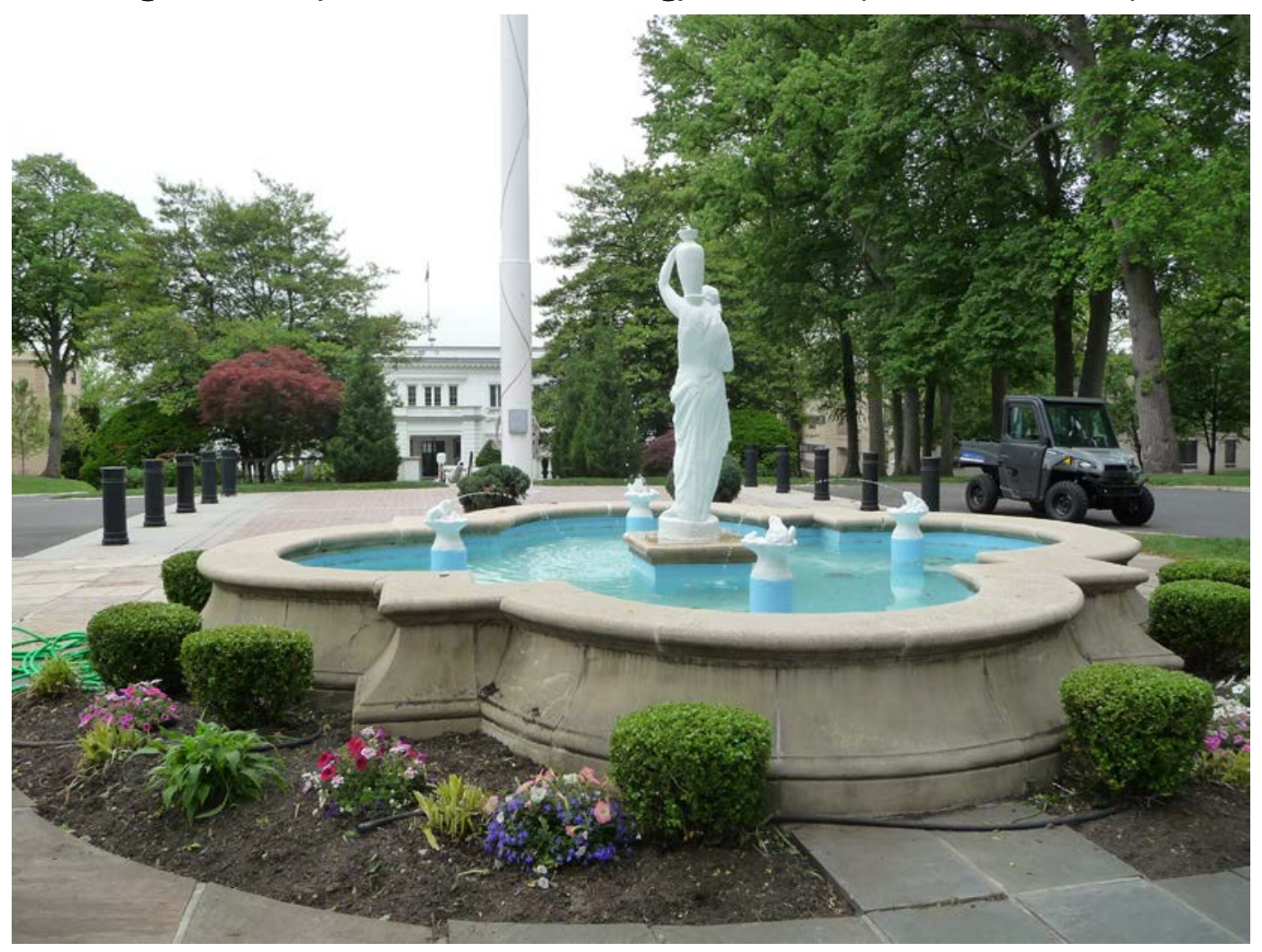

\subsubsection{Flagpole and associated monuments}

The Academy's flagpole is located in the center of the quadrangle and the Academy. The flagpole stands 176 feet in height. The flagpole was moved to this location in 1943 from the site of the deck gun in Powell Oval and now sits on the main east-west axis of the Academy, west of the Amphitrite Pool. Two monuments and markers also are located in the heart of campus, on either side of the Academy's flagpole. On the flagpole's east side is a monument to the USS Missouri (BB-63) (Figure 60), and on the west side is one honoring Vice Admiral Richard McNulty, who is considered to be the "Father of the USMMA" (Figure 61). The Missouri was instrumental in the Japanese surrender that terminated WWII. The monument contains a replica of the plaque that was mounted aboard the Missouri; the replica plaque was given to the Academy by the Secretary of the Navy in 1947. 
Figure 60. The USS Missourimonument and the view north to Truxton Arcade that connects Jones (left) and Barry (right) Halls (ERDC-CERL, 2015).

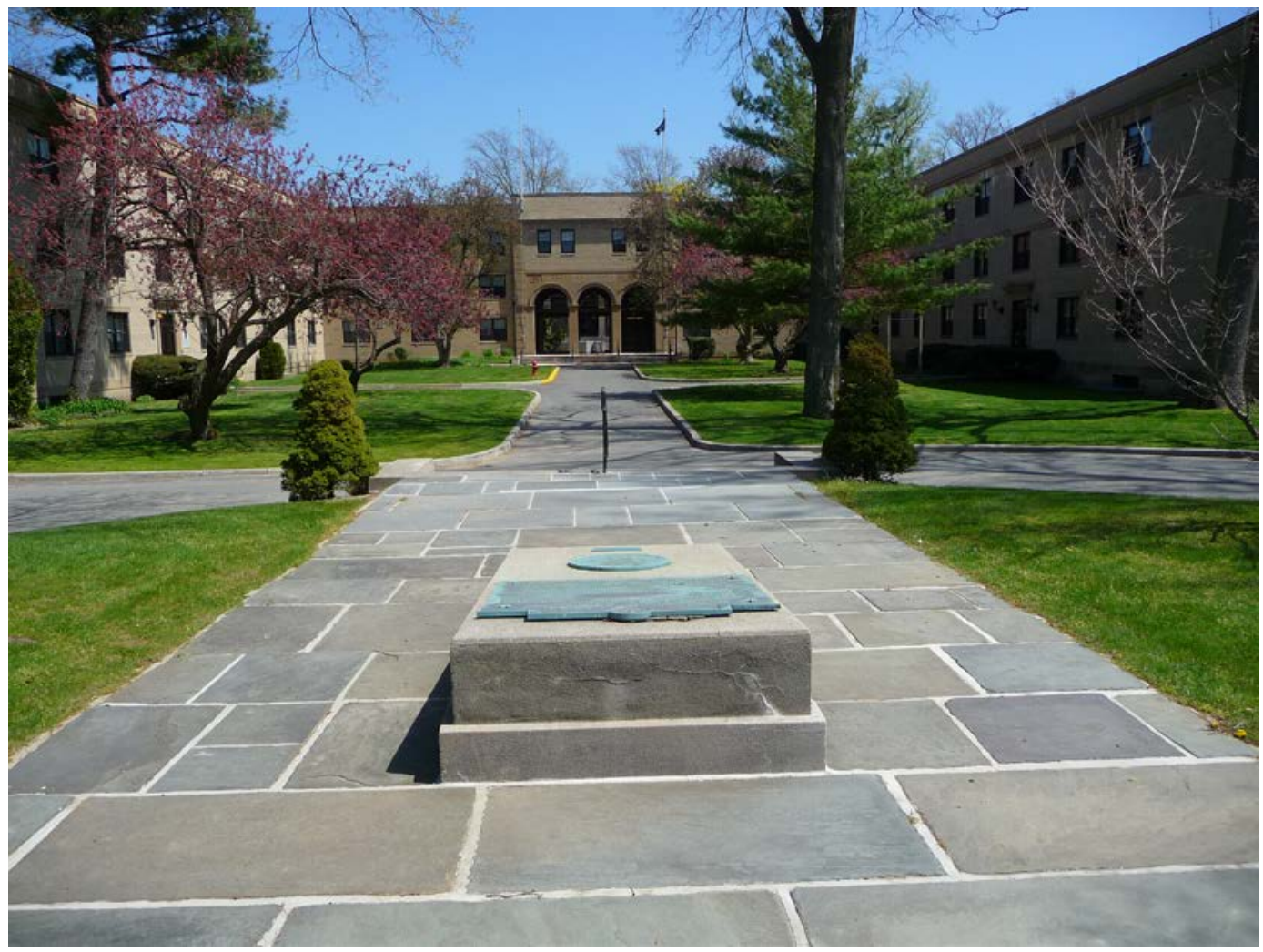

Figure 61. Monument honoring Vice Admiral Richard McNulty (foreground) is located between flagpole and Powell Oval (with deck gun in photo's center)

(ERDC-CERL, 2015).

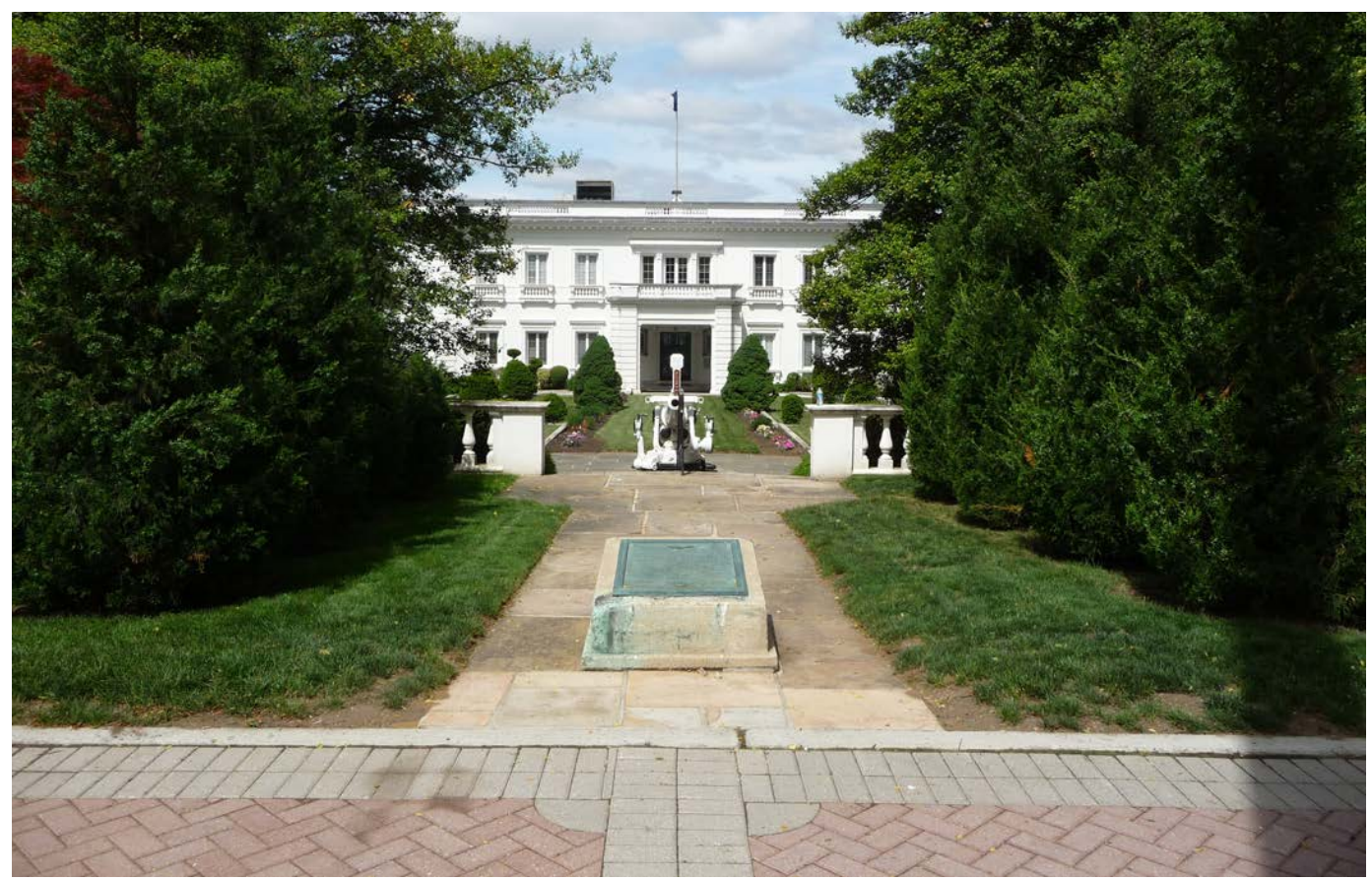




\subsubsection{Wiley Hall Gardens and associated monuments}

In the Powell Oval, located just east of the entrance and portico to Wiley Hall, is a monument to James Harvey Tomb (Figure 62), the first superintendent of the USMAA. East of this monument is the Kings Point Bell (dated 1959) and the Hagner Sundial (no date), which was presented to USMMA by Mr. F. H. Hagner, President of Position Finder Corp, San Antonio, TX (Figure 63). Just east of the sundial is a 5 -inch deck gun, which was placed in this location in 1942 (Figure 64).

Figure 62. James Harvey Tomb monument (foreground) in line with Kings Point Bell, sundial, deck gun, and flagpole in background (ERDC-CERL, 2015).

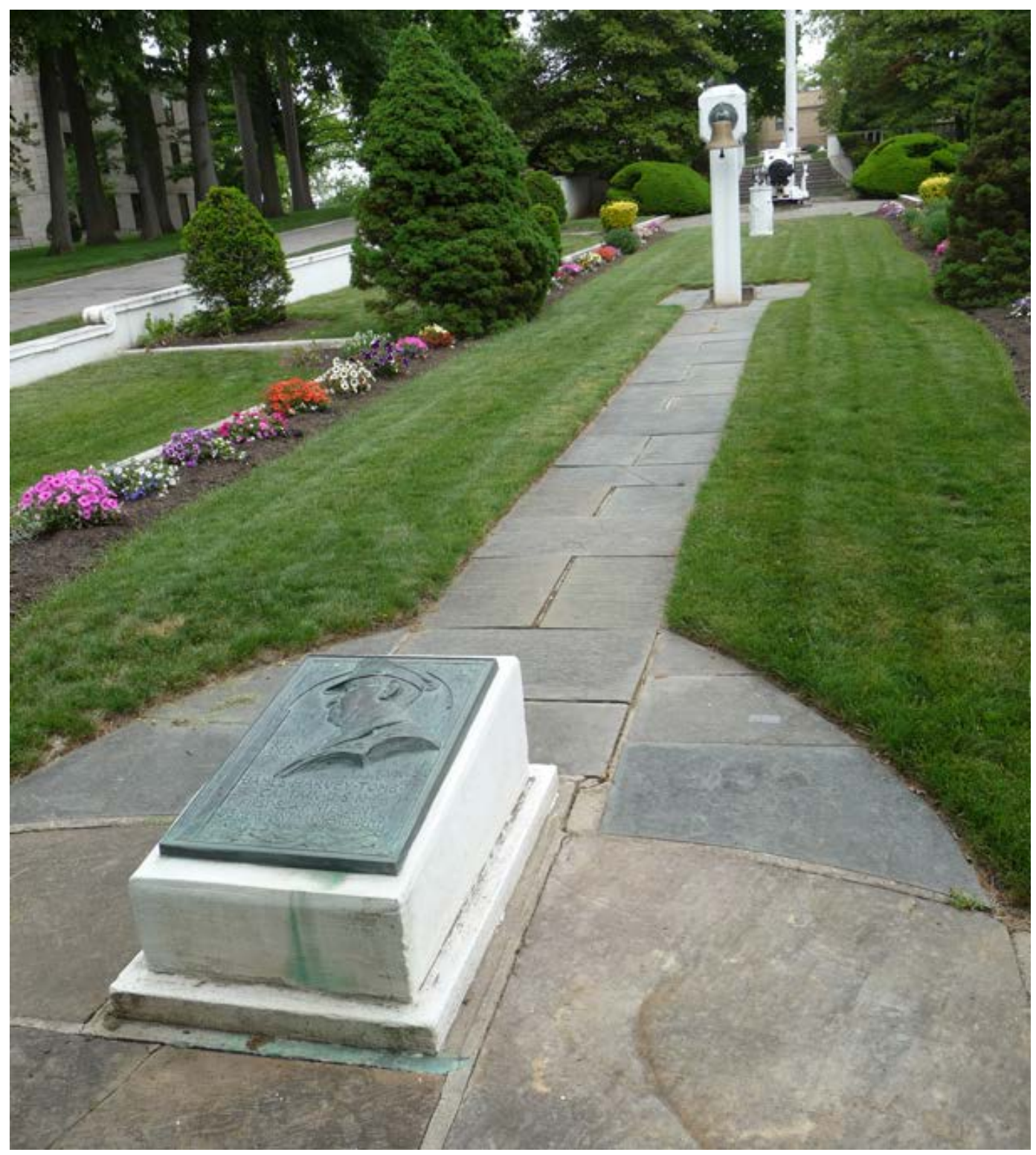


Figure 63. Sundial and 5-inch deck gun in Powell Oval (ERDC-CERL, 2015).

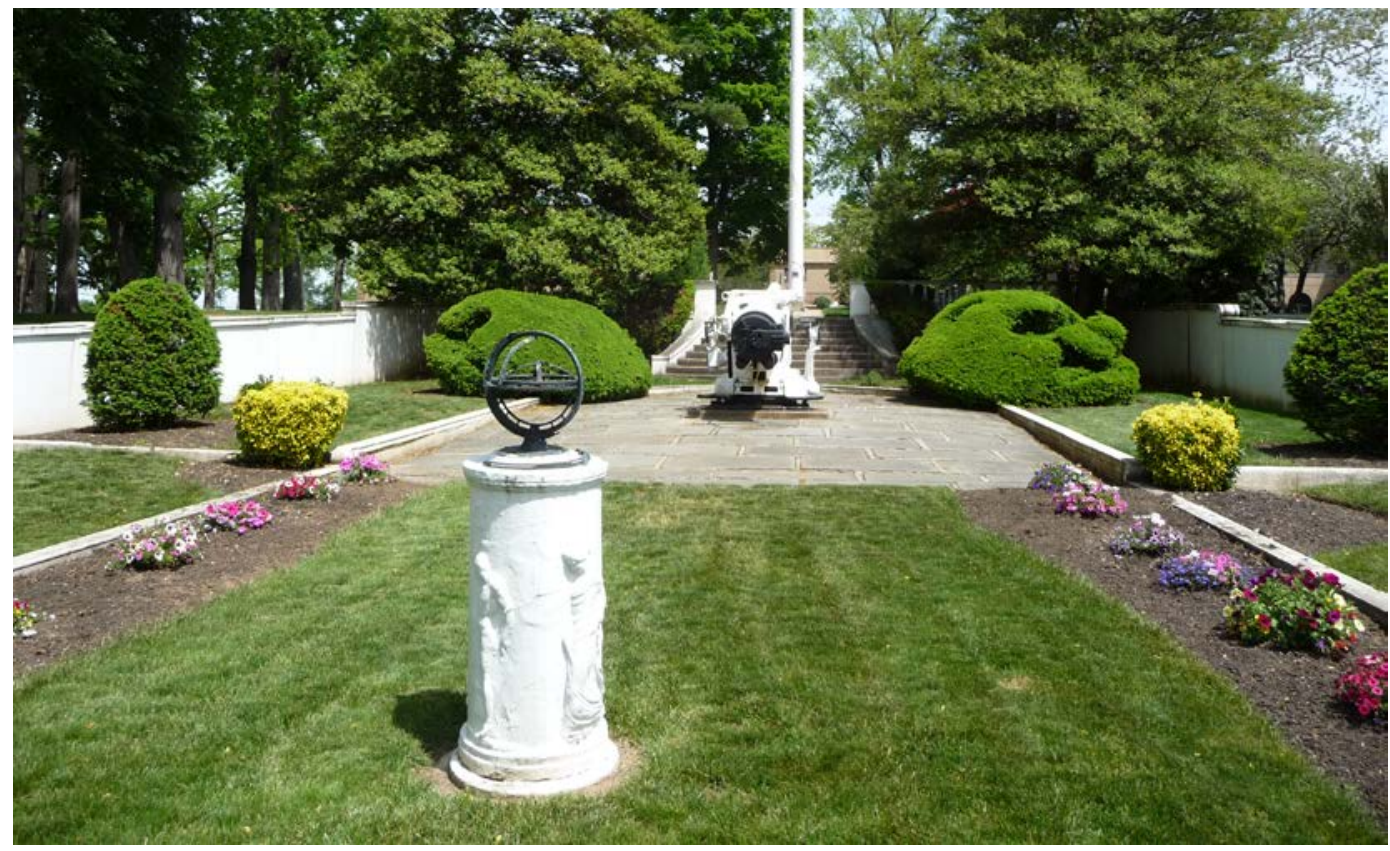

Figure 64. Training gun placement with flagstone paving being laid adjacent to flagpole, 1942 (USMMA Bland Library). Note CCC buildings in background. Flagpole was moved in 1943 to its current location.

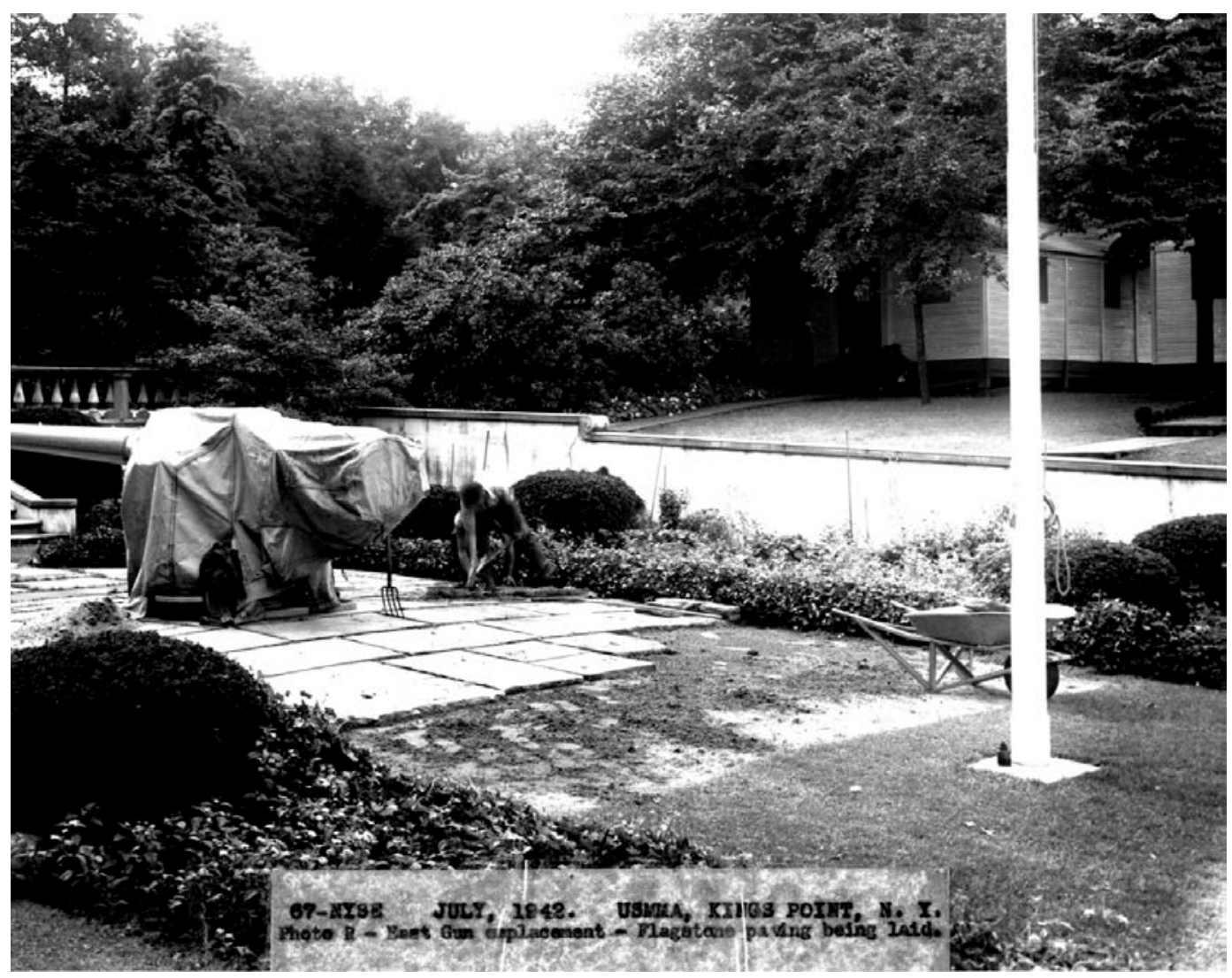


Several urns and benches, which match the retaining walls and terrace structures, adorn the terraces outside the rear of Wiley Hall (Figure 65). It is assumed that these features pre-date the Academy and contribute to the remaining landscape and gardens of the Chrysler mansion.

Figure 65. One of the urns on the terraces at the rear of Wiley Hall (ERDC-CERL, 2015).

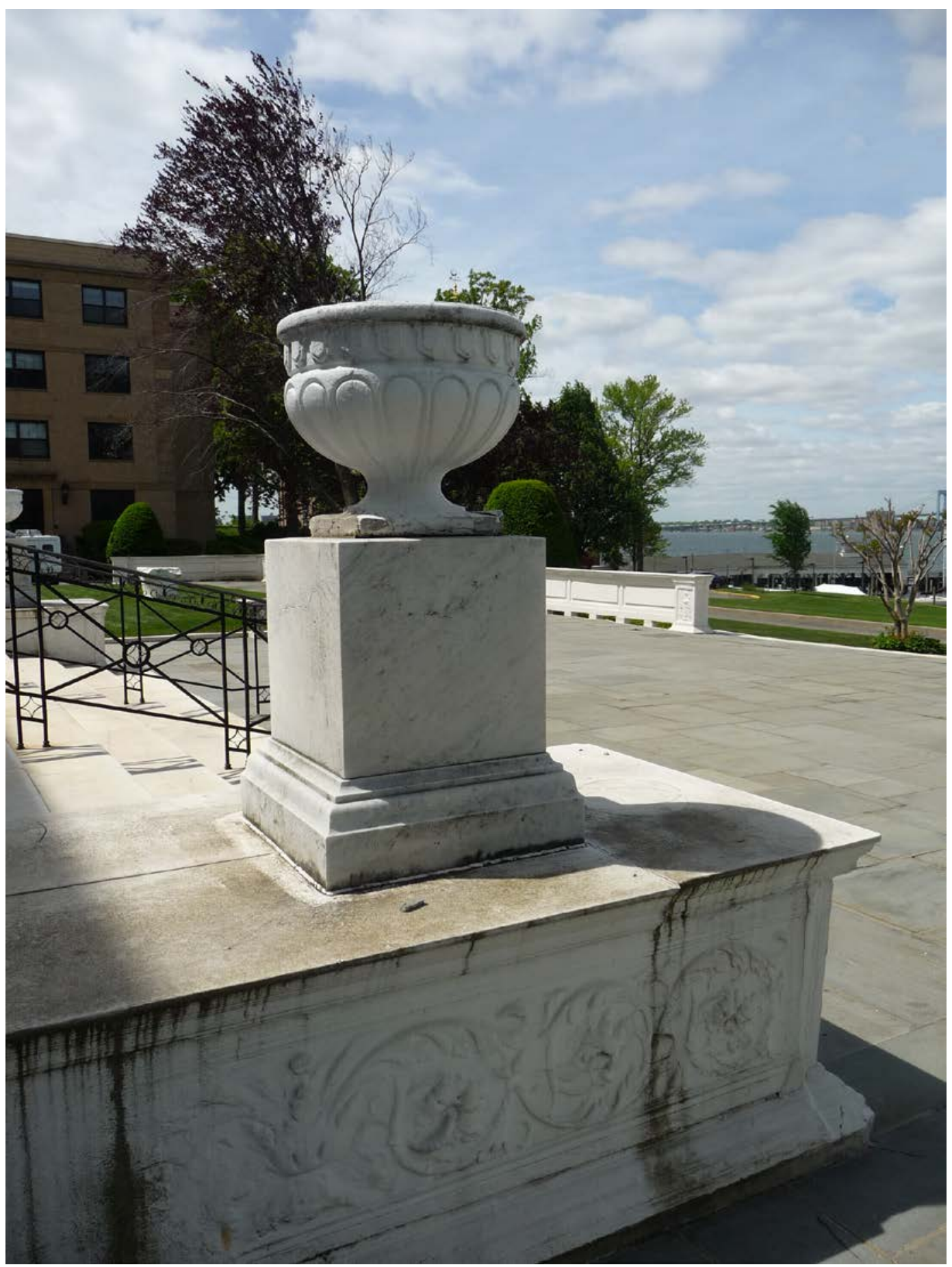




\subsubsection{WWII Monument and Bell}

A large WWII monument with a bell on top sits between Wiley Hall and the waterfront on one of Wiley Hall's lower terraces (Figure 66). The monument commemorates the cadet midshipmen and graduates of the USMMA who were lost in WWII. The plaque was presented by the class of 1943, the base was presented by cadet midshipmen 1942-1946, and the monument was donated by Bethlehem Steel Company. The base contains four urns, one at each corner, which now house lights. The monument is encircled by the path from Wiley Hall to the pool that is accented by evergreen shrubs.

Figure 66. WWII monument and bell (ERDC-CERL, 2015).

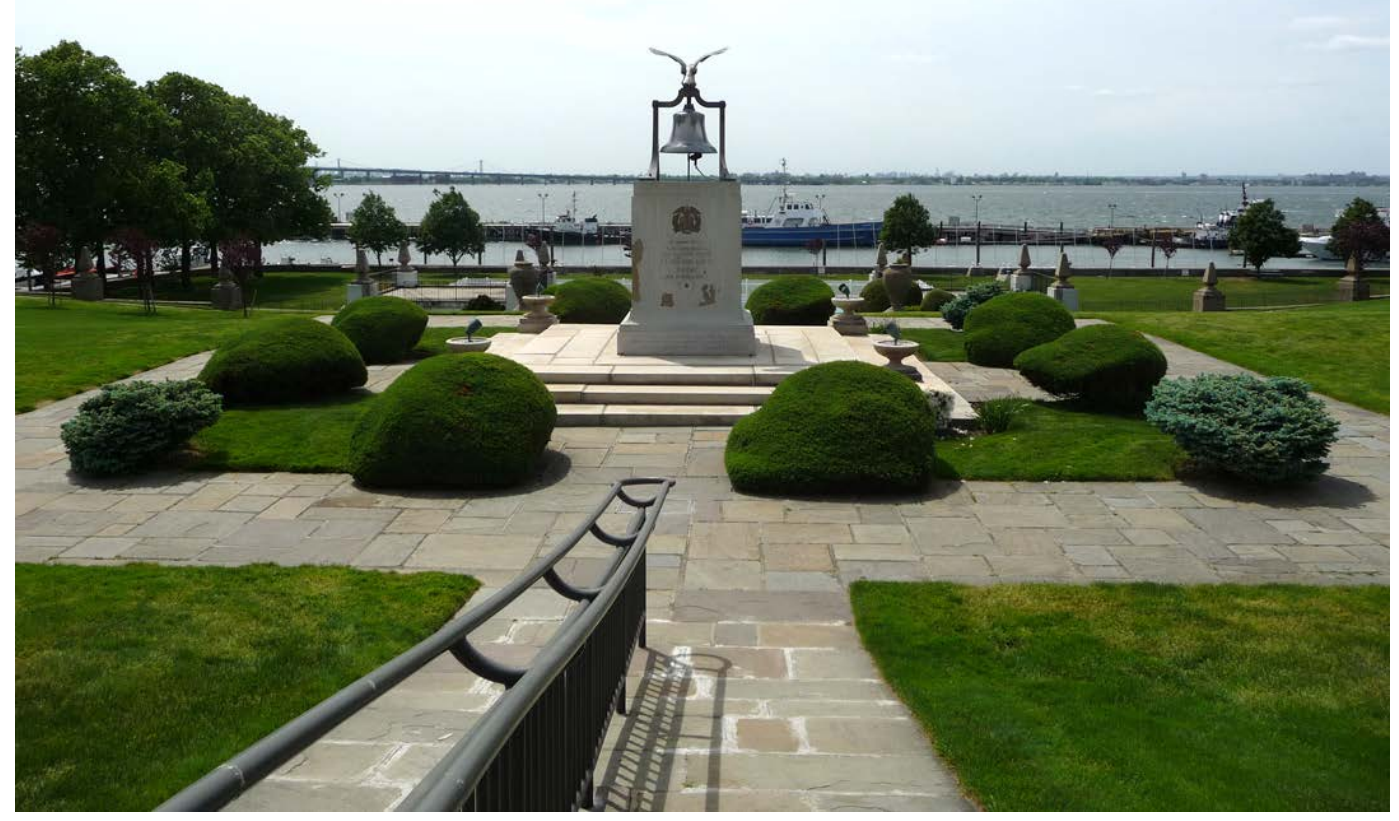

\subsubsection{The Kings Point Eagles}

The Kings Point Eagles are two of the fourteen commissioned by architect Stanford White in 1909 and sculpted by Adolph Alexander Weinman for the 7th Avenue facade of the original Penn Station in New York City. The Kings Point Eagles are located in front of O'Hara Hall (Figure 67). It is unknown when these two sculptures were moved and added to the USMMA landscape. 
Figure 67. One of the Kings Point Eagles located in front of O'Hara Hall (ERDC-CERL, 2015).

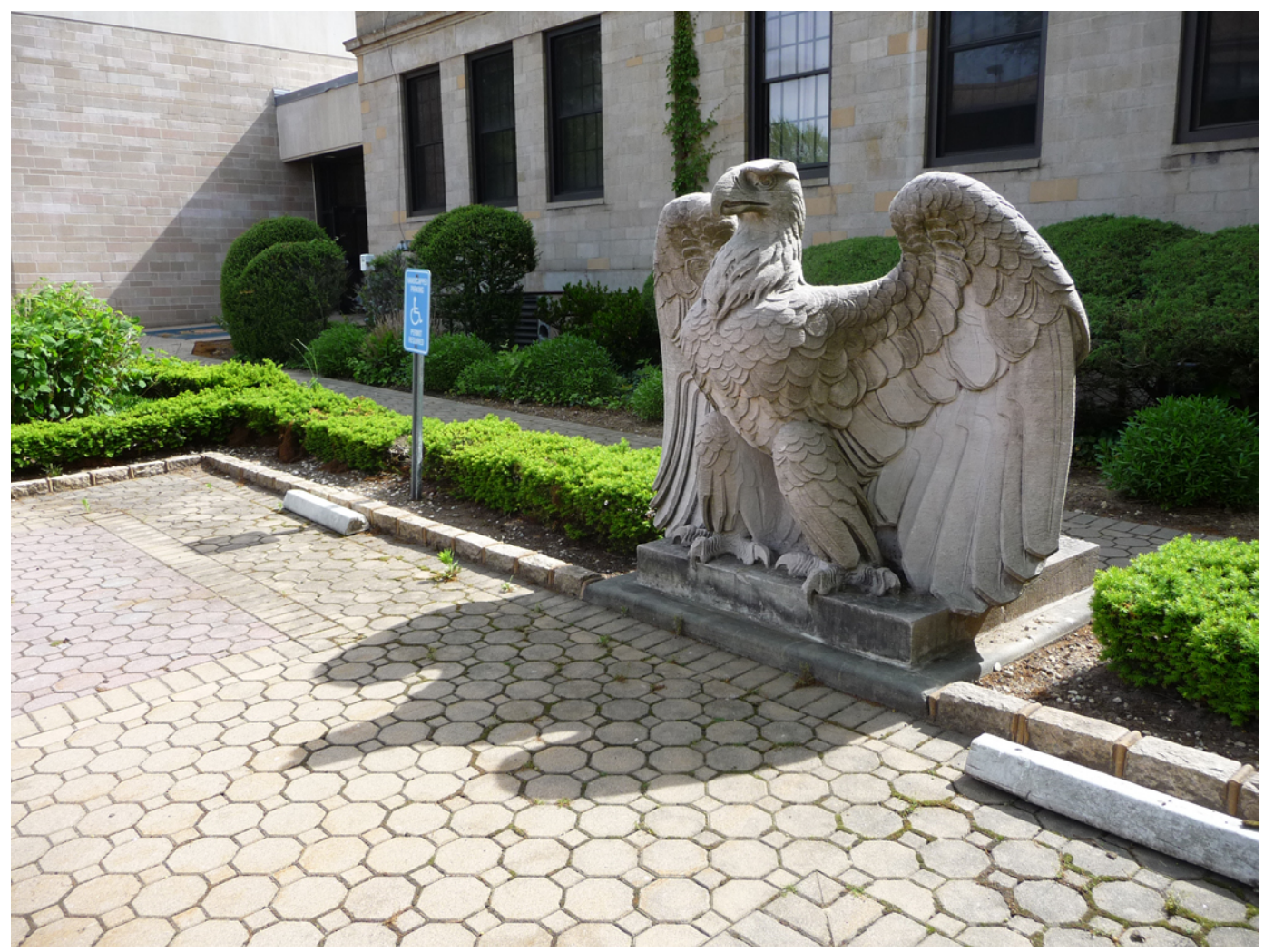

\subsubsection{The Mariner Monument}

The Mariner Monument, located north of the Natatorium at the Vickery Gate entrance to the Academy (Figure 68), was dedicated in 2003 as a symbol of the "invaluable contributions of Kings Pointers past and present-in service to the maritime industry and to our country, in time of war and peace-while looking to the great promise of our future midshipmen.” It is one of the first views as one enters the USMMA. 
Figure 68. The Mariner Monument is located by the Vickery Gate entrance to USMMA (ERDC-CERL, 2015).

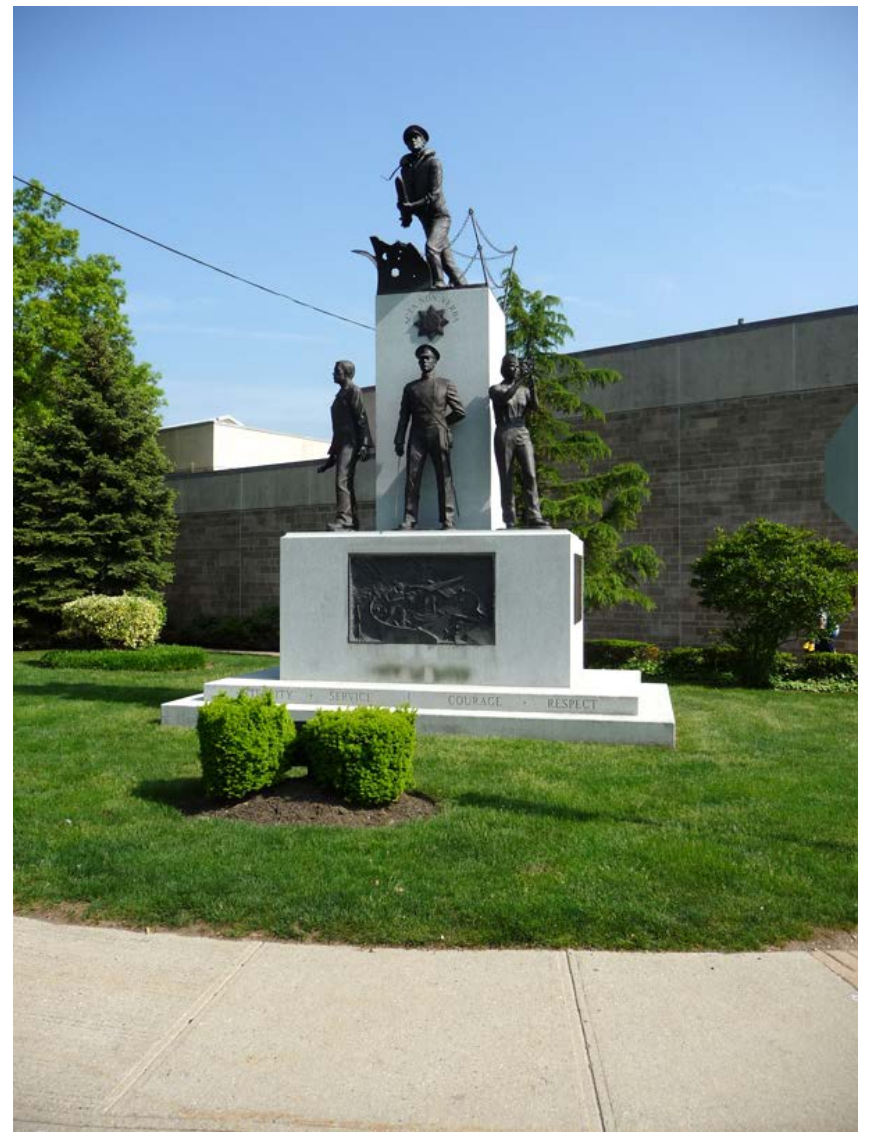

\subsubsection{Other monuments}

More recent monuments and memorials have been added after the period of significance and therefore, they are noncontributing to the USMMA Historic District (Figure 69-Figure 78). 
Figure 69. Monument to Ricardo and Rita Alvarado, with plaque added on existing boat mooring in 2001 (ERDC-CERL, 2015).

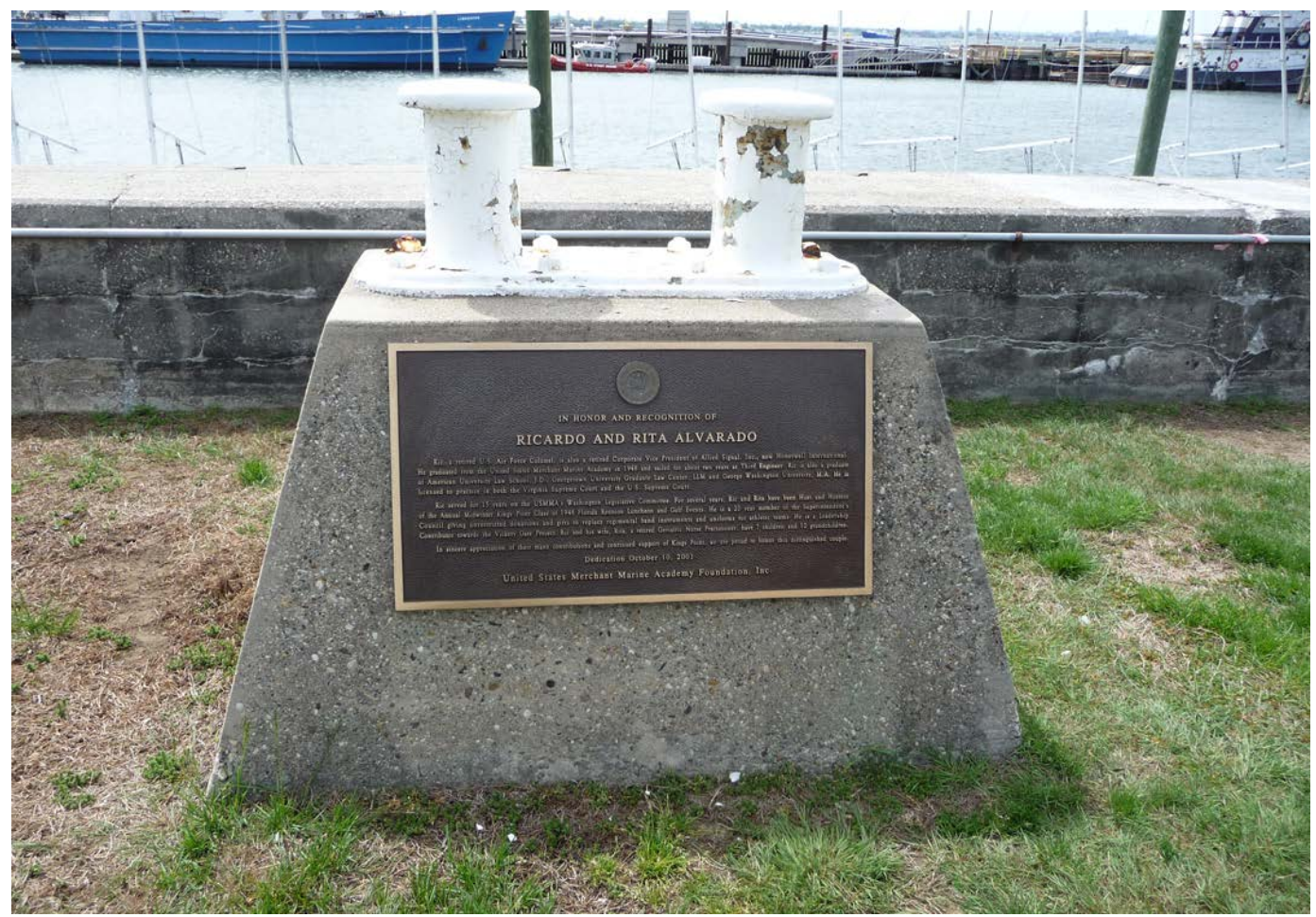

Figure 70. Memorial to those who perished on 9 March 1945, with plaque added on an existing boat mooring (ERDC-CERL, 2015).

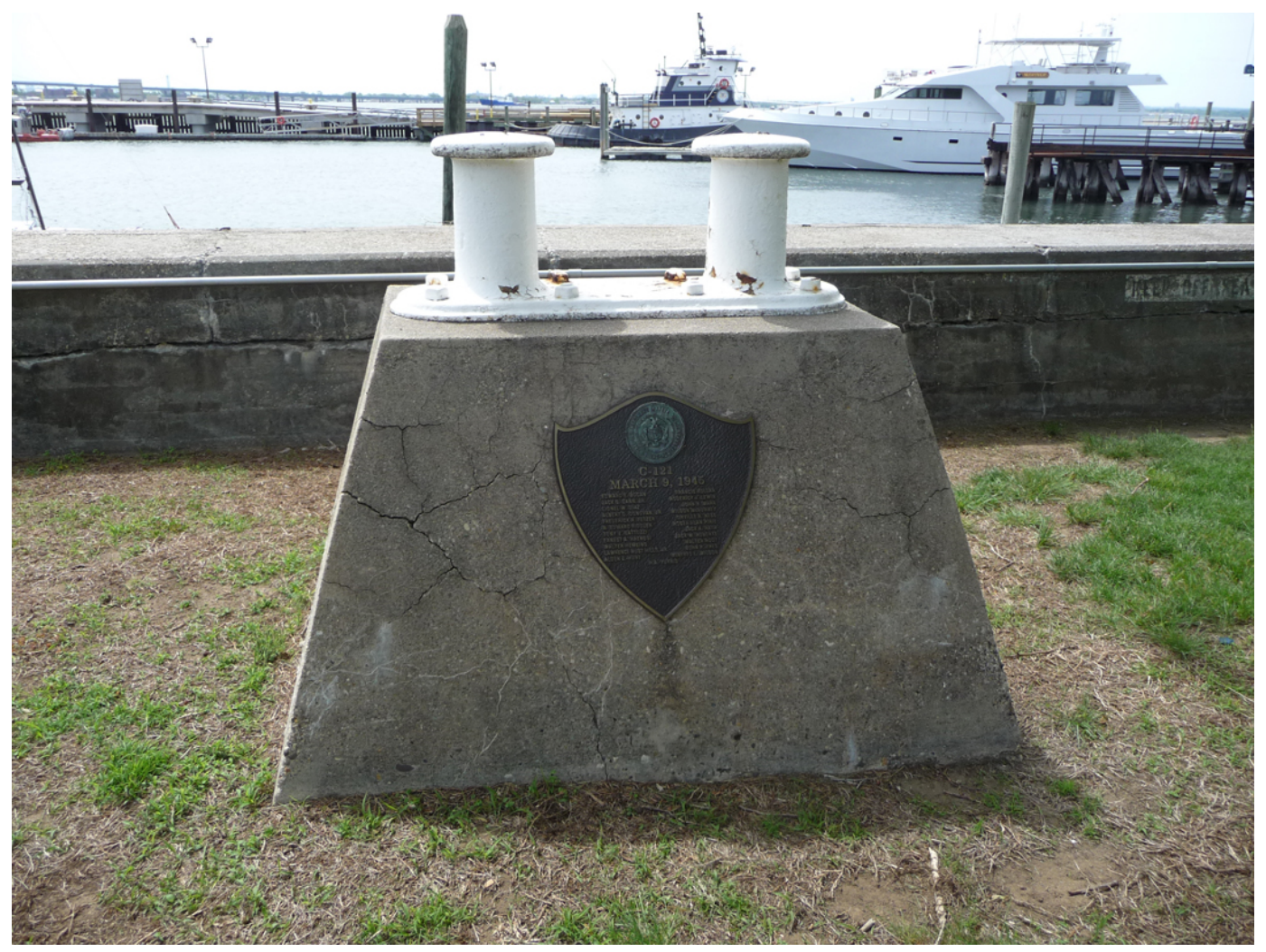


Figure 71. Marker placed on an existing mooring in 1980 to thank Mr. and Mrs J. Seward Johnson for the research vessel Mazurka (ERDC-CERL, 2015).

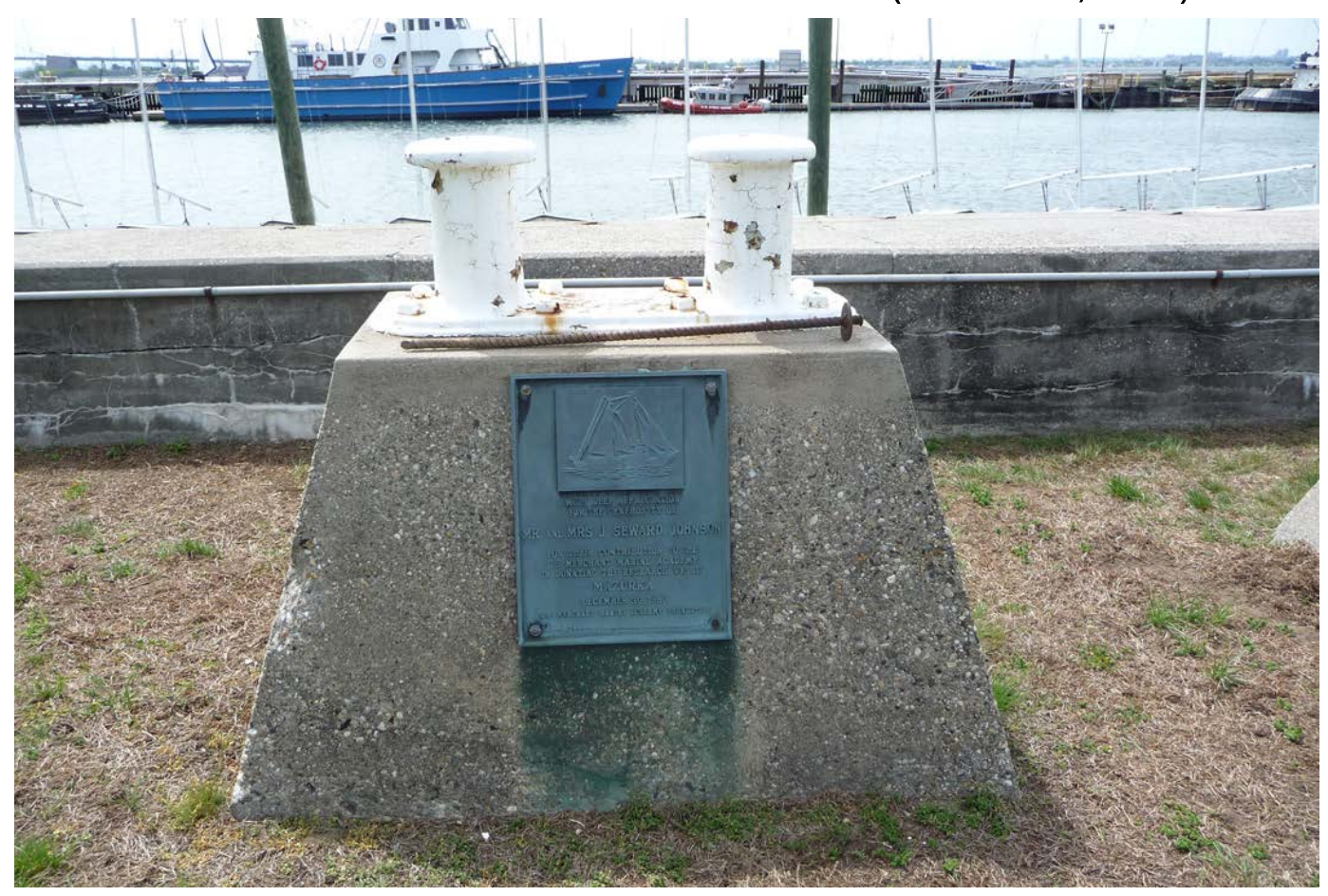

Figure 72. Ackerman Anchor, in recognition of James H. Ackerman in 1988, is located adjacent to Vickery Gate (ERDC-CERL, 2015).

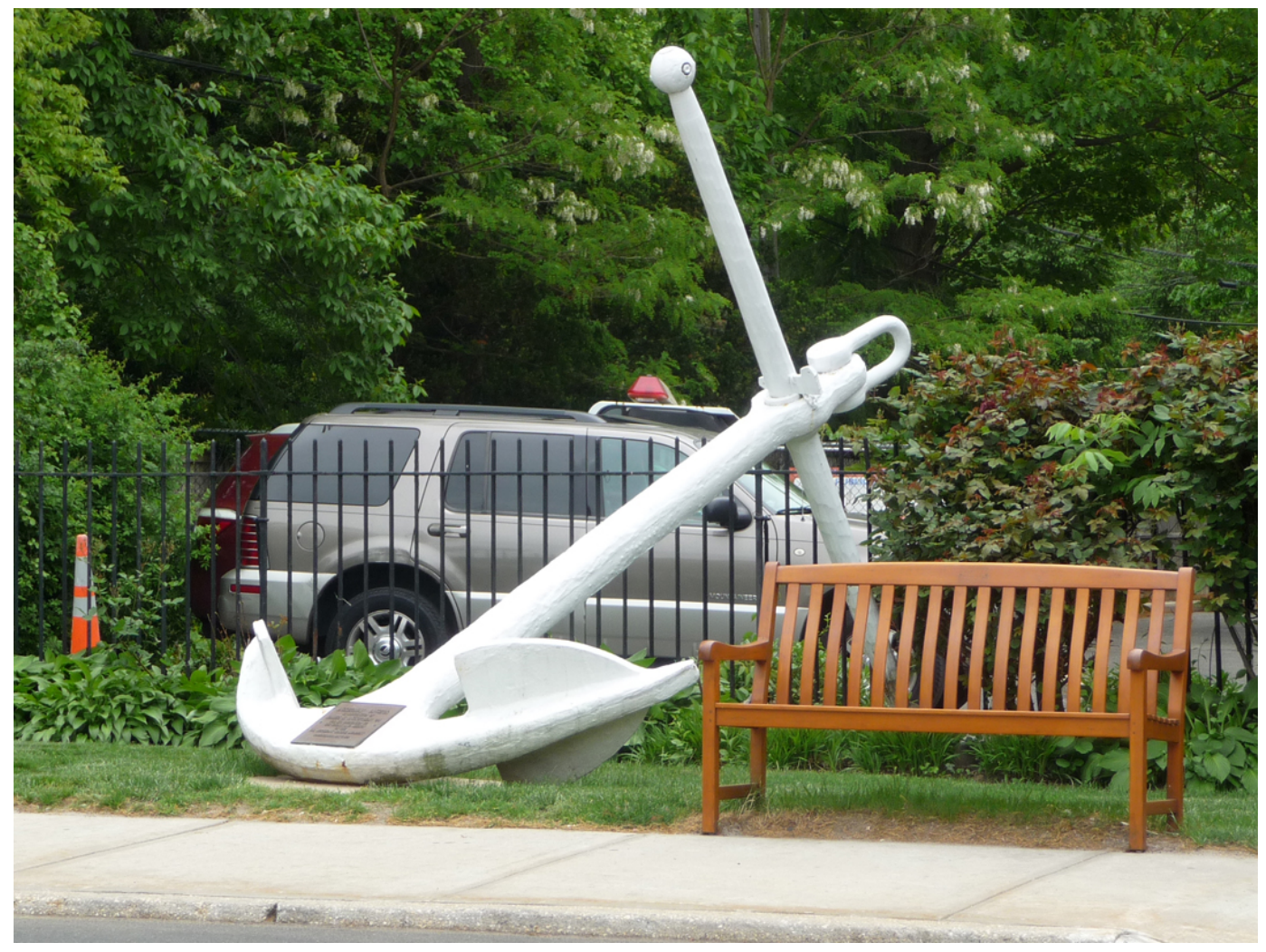


Figure 73. Krinsky Circle monument, given for RADM Paul L. Krinsky, in front of Melville Hall (ERDC-CERL, 2015).

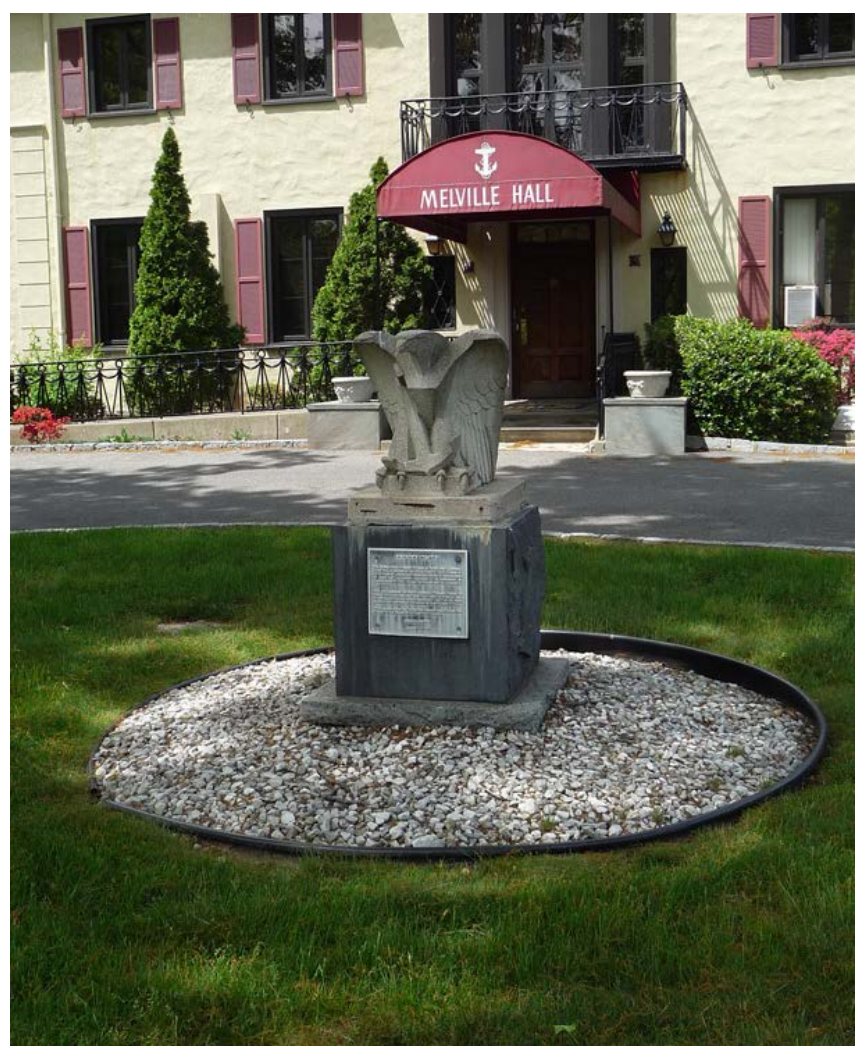

Figure 74. Propeller in front of Yocum Sailing Center (ERDC-CERL, 2015).

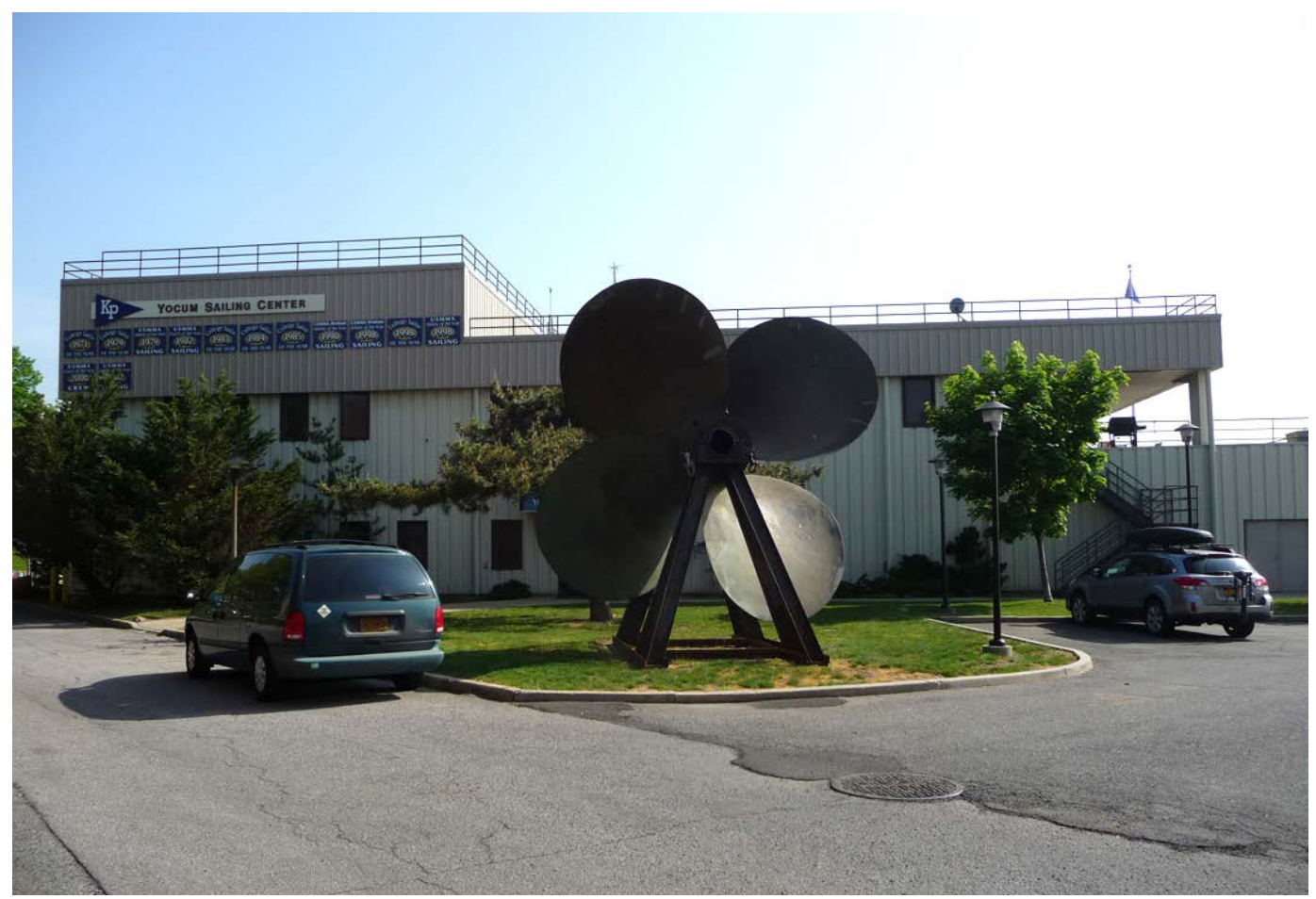


Figure 75. The Bjornson Anchor, a memorial for Lars Cameron Bjornson, located in front of the chapel (ERDC-CERL).

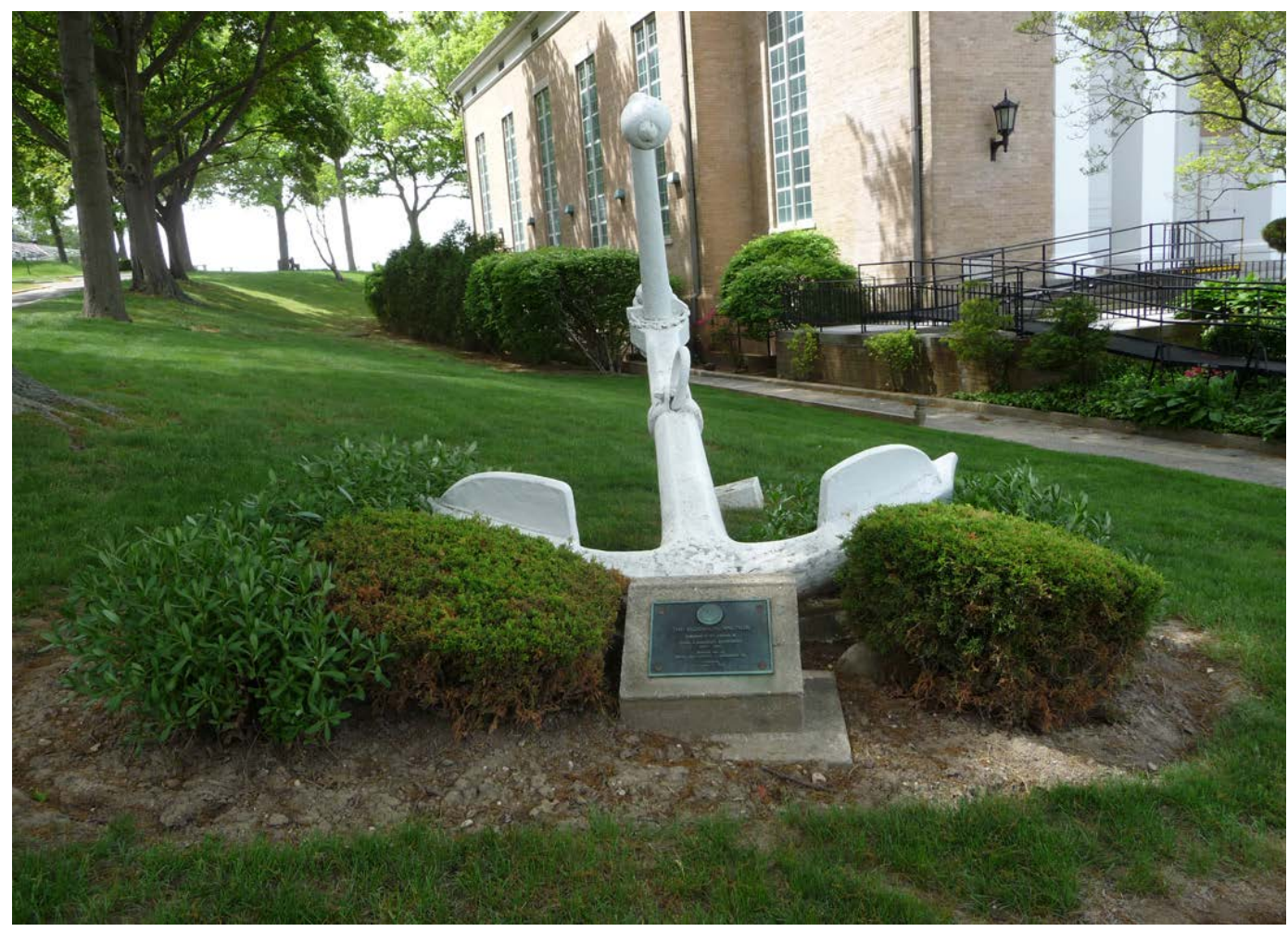

Figure 76. Unmarked anchor in front of gate to Barstow Mansion (now the American Merchant Marine Museum) (ERDC-CERL, 2015).

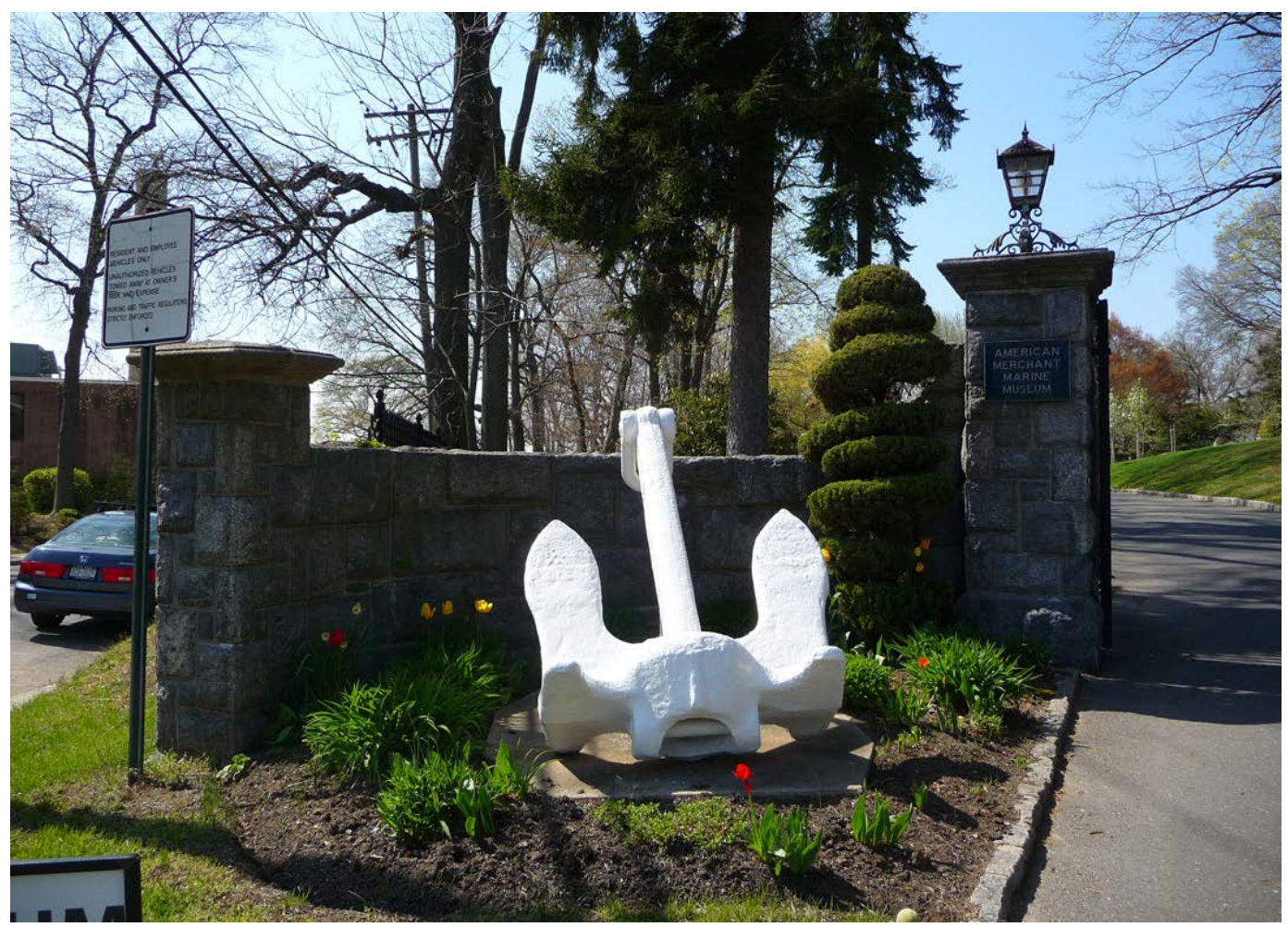


Figure 77. WWII troopship propeller, adjacent to Barstow Mansion (now the American Merchant Marine Museum; ERDC-CERL, 2015).

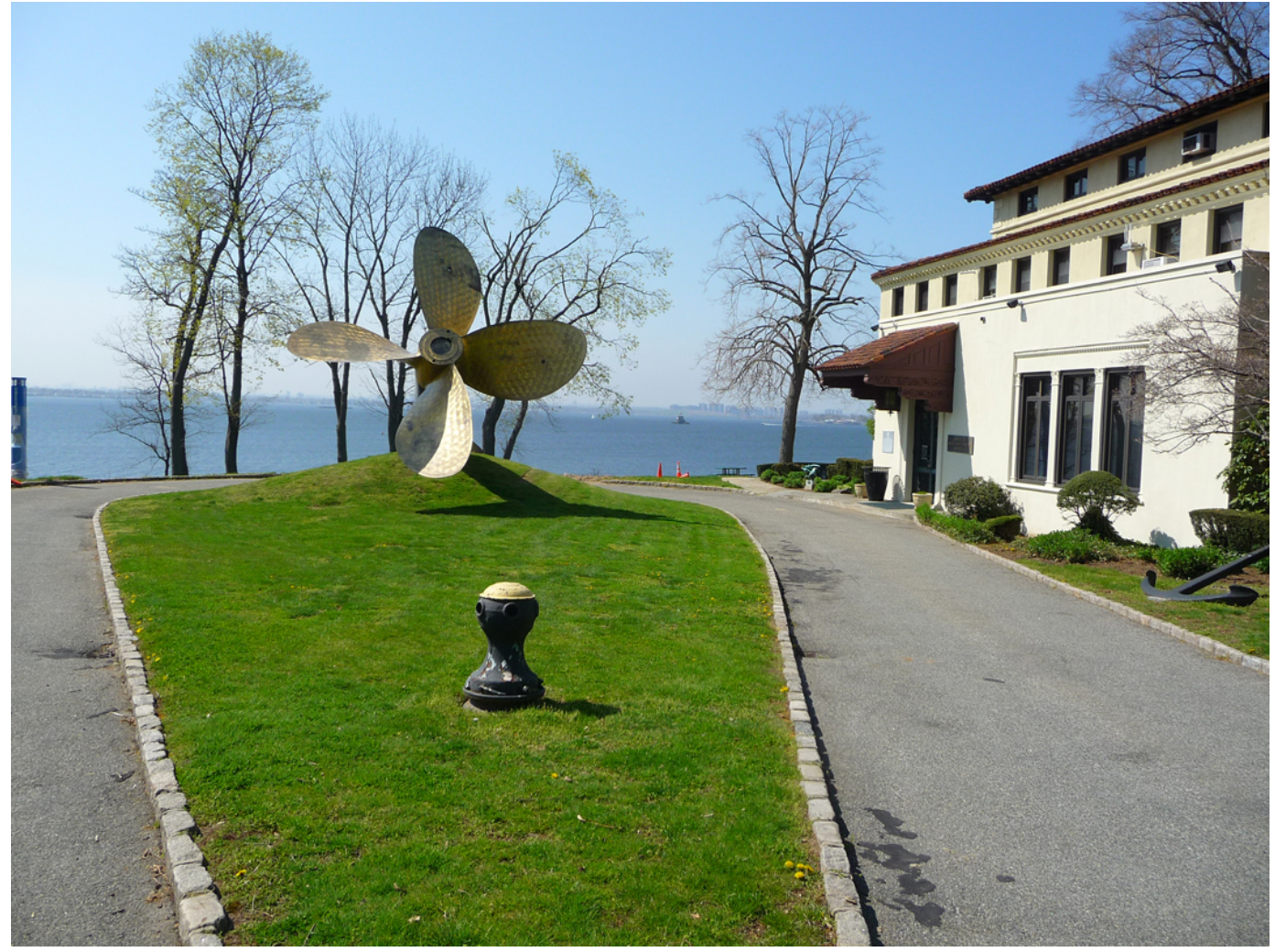

Figure 78. Gun memorial, dedicated to the U.S.N. Armed Guard of World War II and U.S. Liberty vessel SS J. Pinckney Henderson at site of former Barstow estate's gardens (ERDC-CERL, 2015).

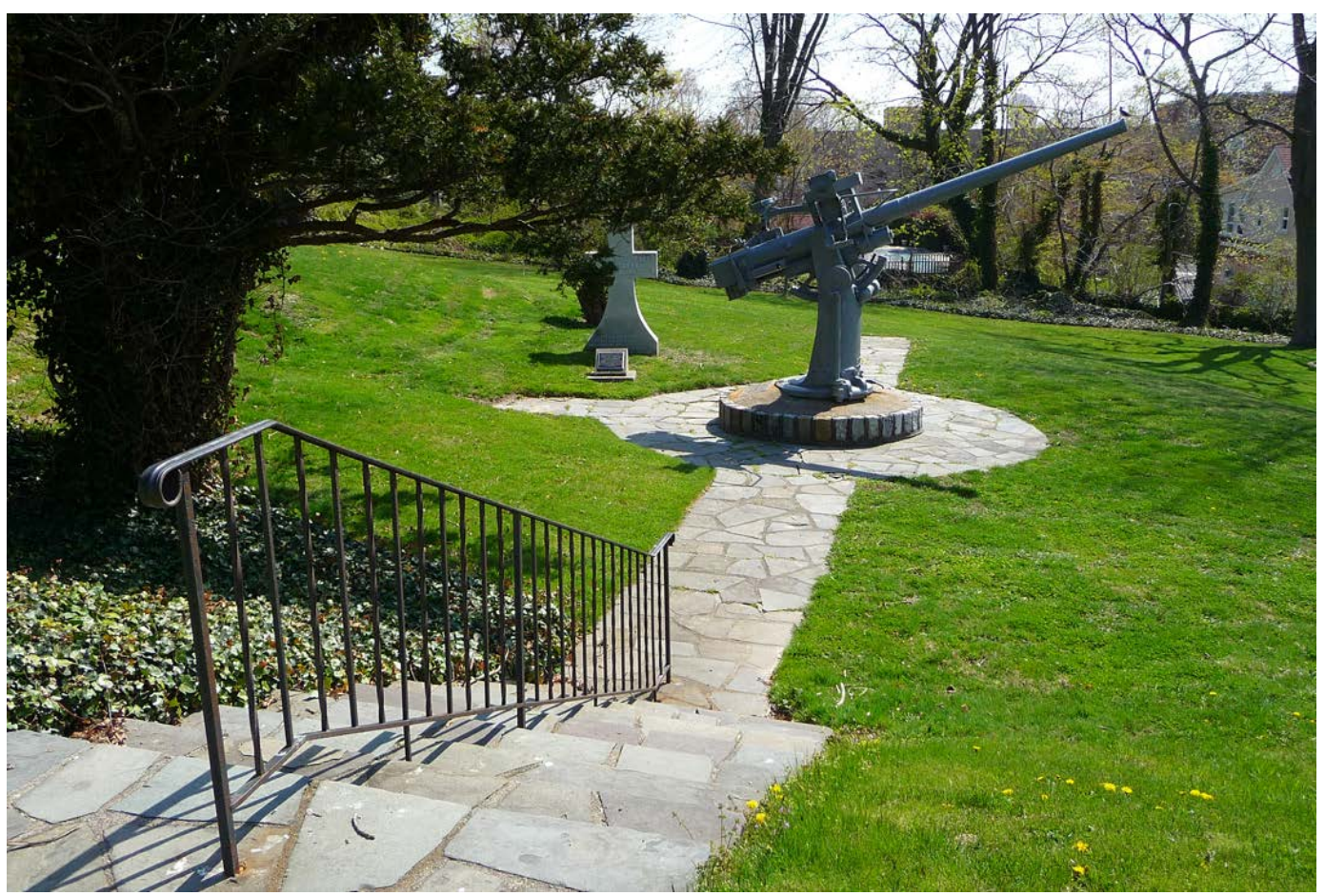


2.1.7.8 New monuments, memorials and graduating class gifts (noncontributing)

More recent additions to the landscape also include class benches and memorials (Figure 79-Figure 86). Most are located between the Chapel and Wiley Hall. These small-scale features have been added after the period of significance and are noncontributing.

Figure 79. Bench from Class of 1996 in memory of Brian Thomas Patrick Roche, located in front of the Chapel (ERDC-CERL, 2015).

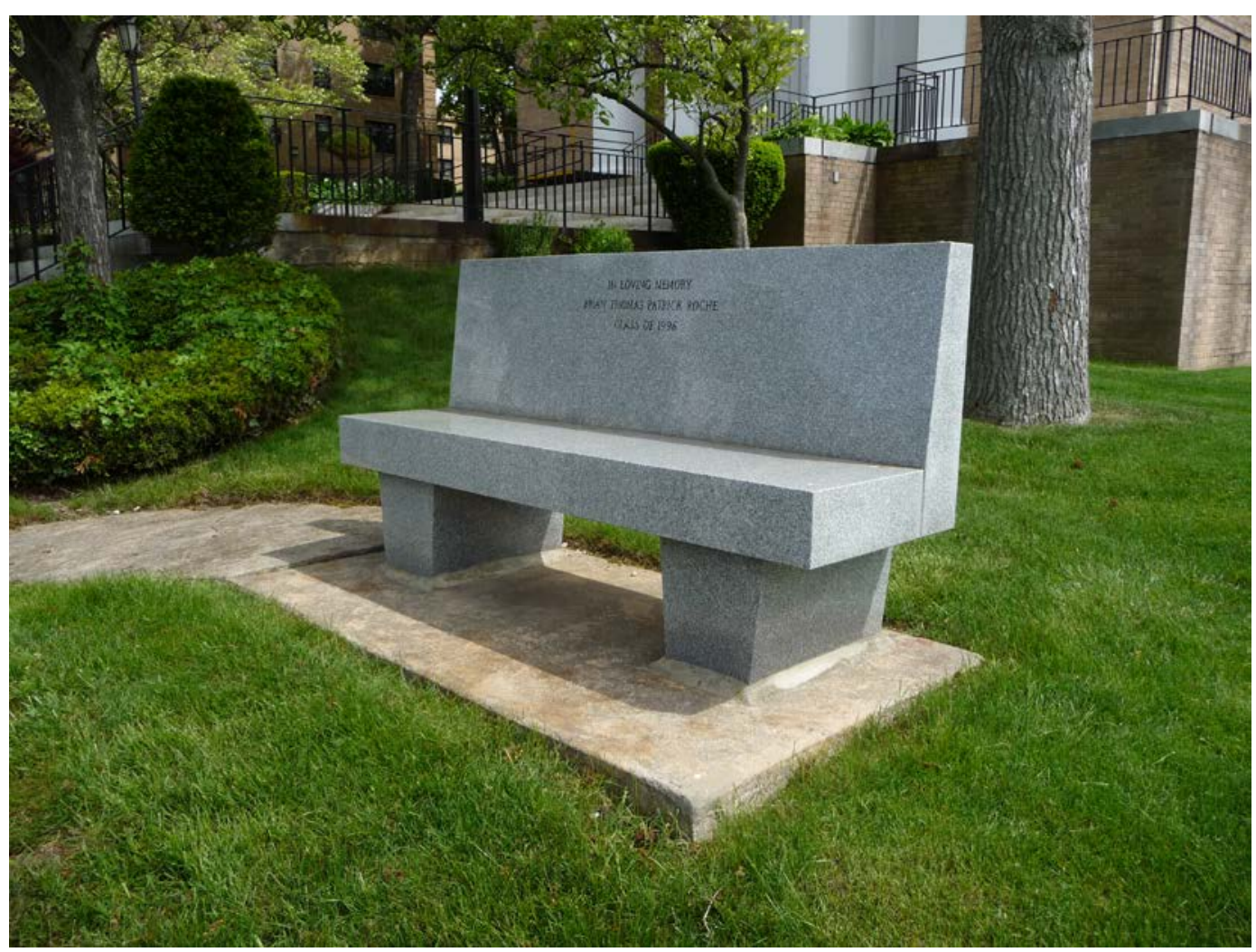


Figure 80. Class of 1942 memorial bench is located between Chapel and Wiley Hall (ERDC-CERL, 2015).

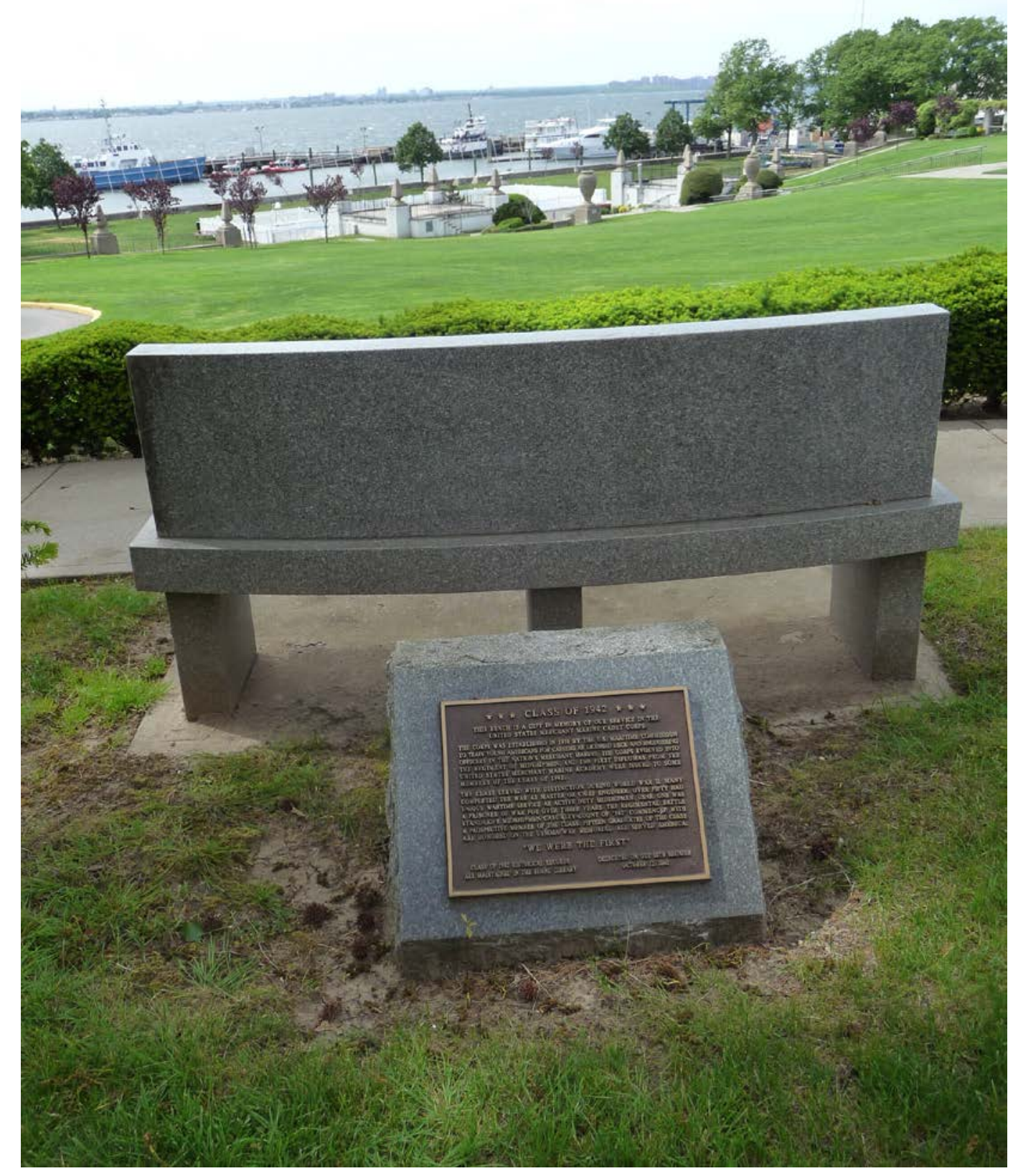


Figure 81. World Trade Center Memorial located near the Chapel (ERDC-CERL, 2015).

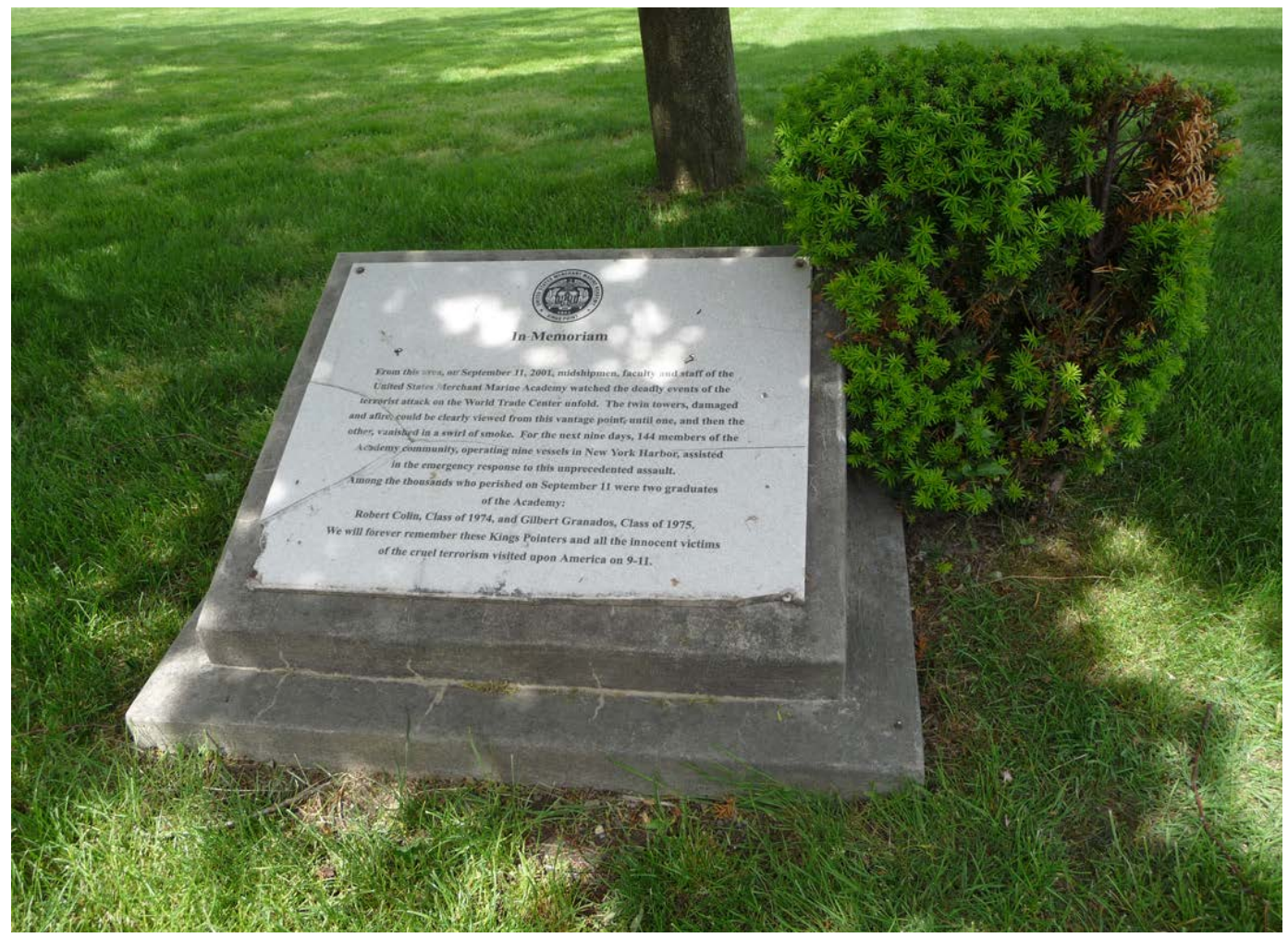

Figure 82. Iris garden in memory of Doris H. Sherman is located adjacent to the Chrysler mansion pergola (ERDC-CERL, 2015).

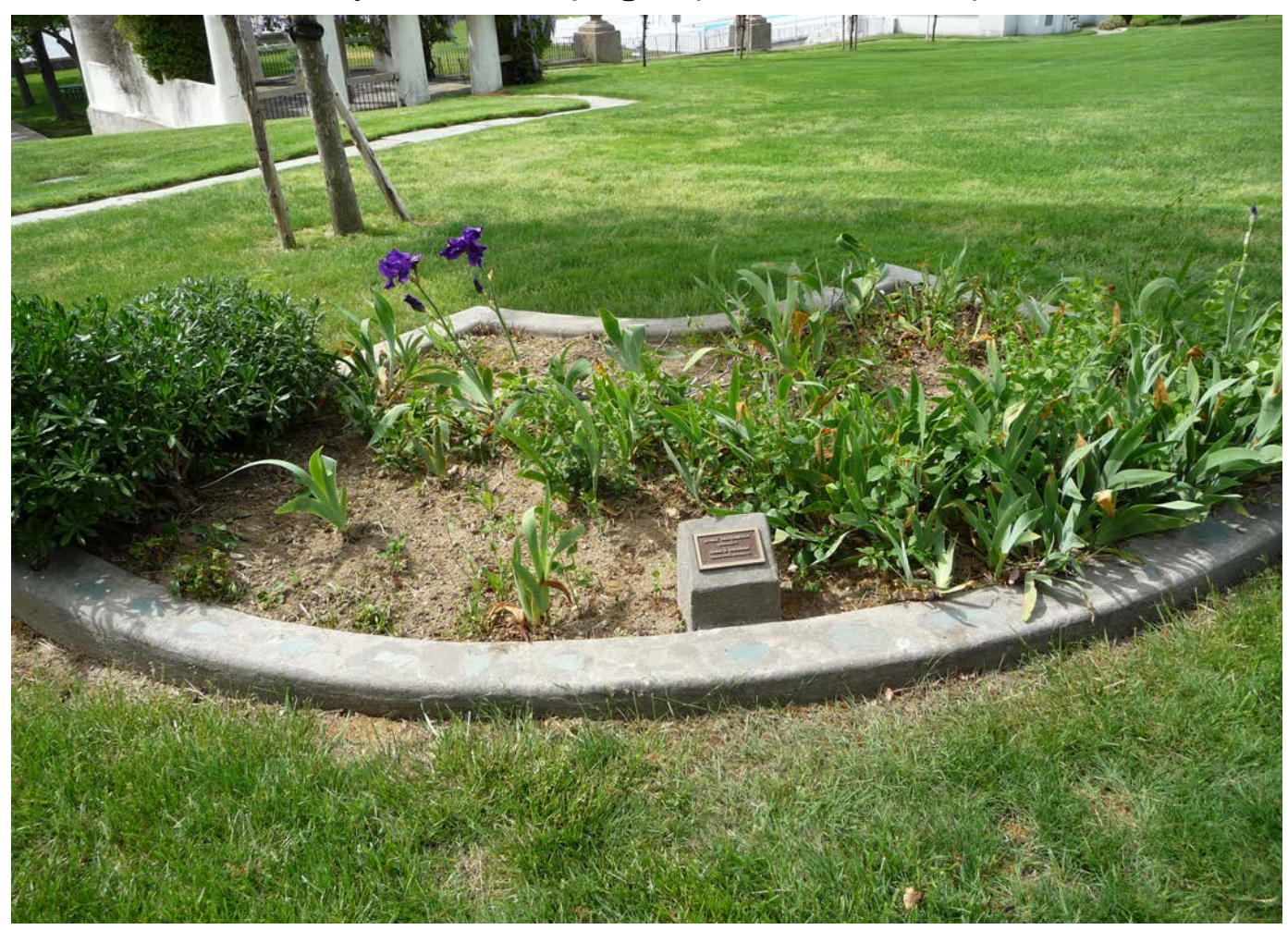


Figure 83. Scott Michael Heilman, Jr. memorial lookout is adjacent to Melville Hall (ERDC-CERL, 2015).

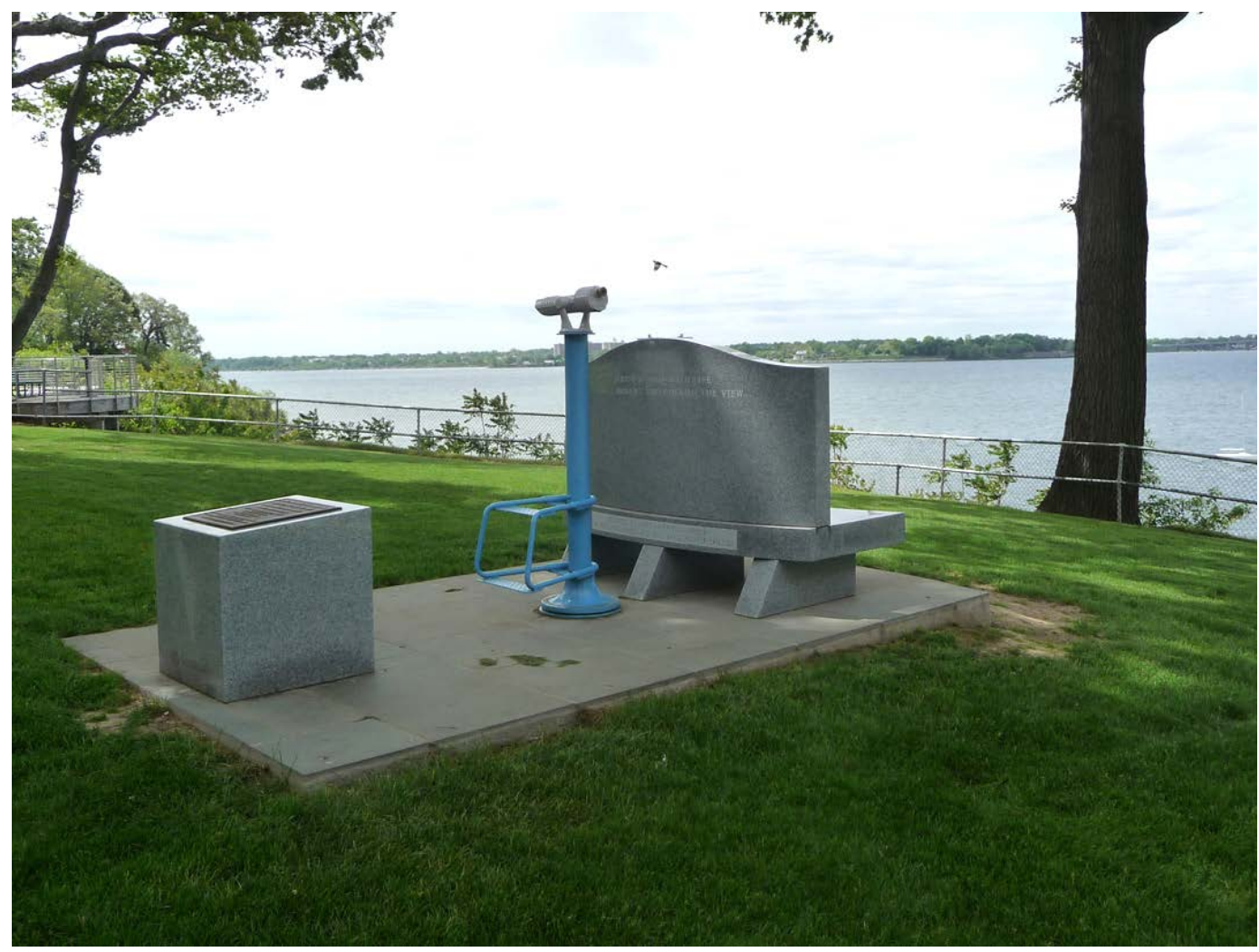

Figure 84. Memorial bench for Aaron N. Seesan, Class of 2003, in front of Land Hall (ERDC-CERL, 2015).

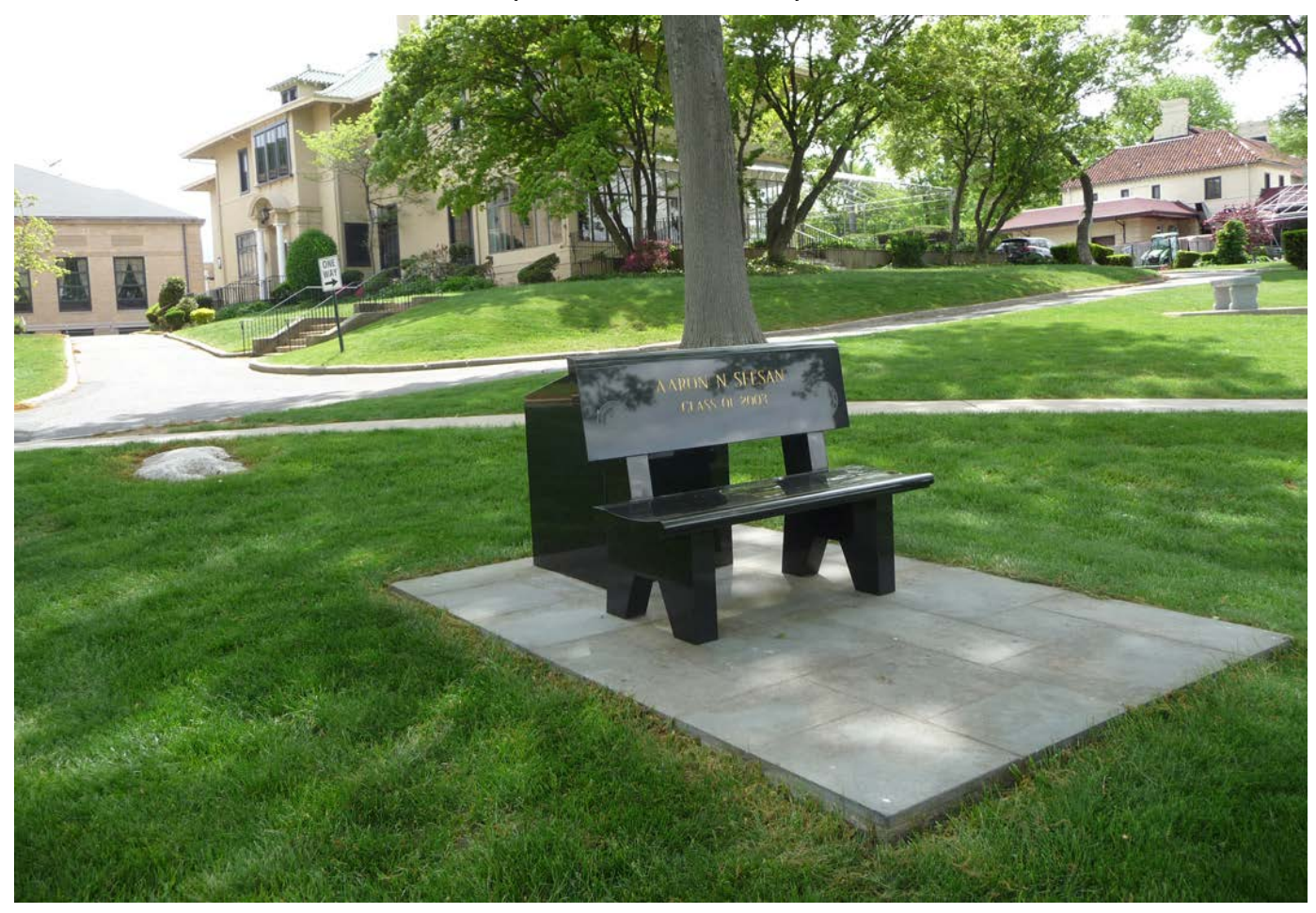


Figure 85. Bench given by Class of 1956 in memory of deceased class members in rear of Wiley Hall (ERDC-CERL, 2015).

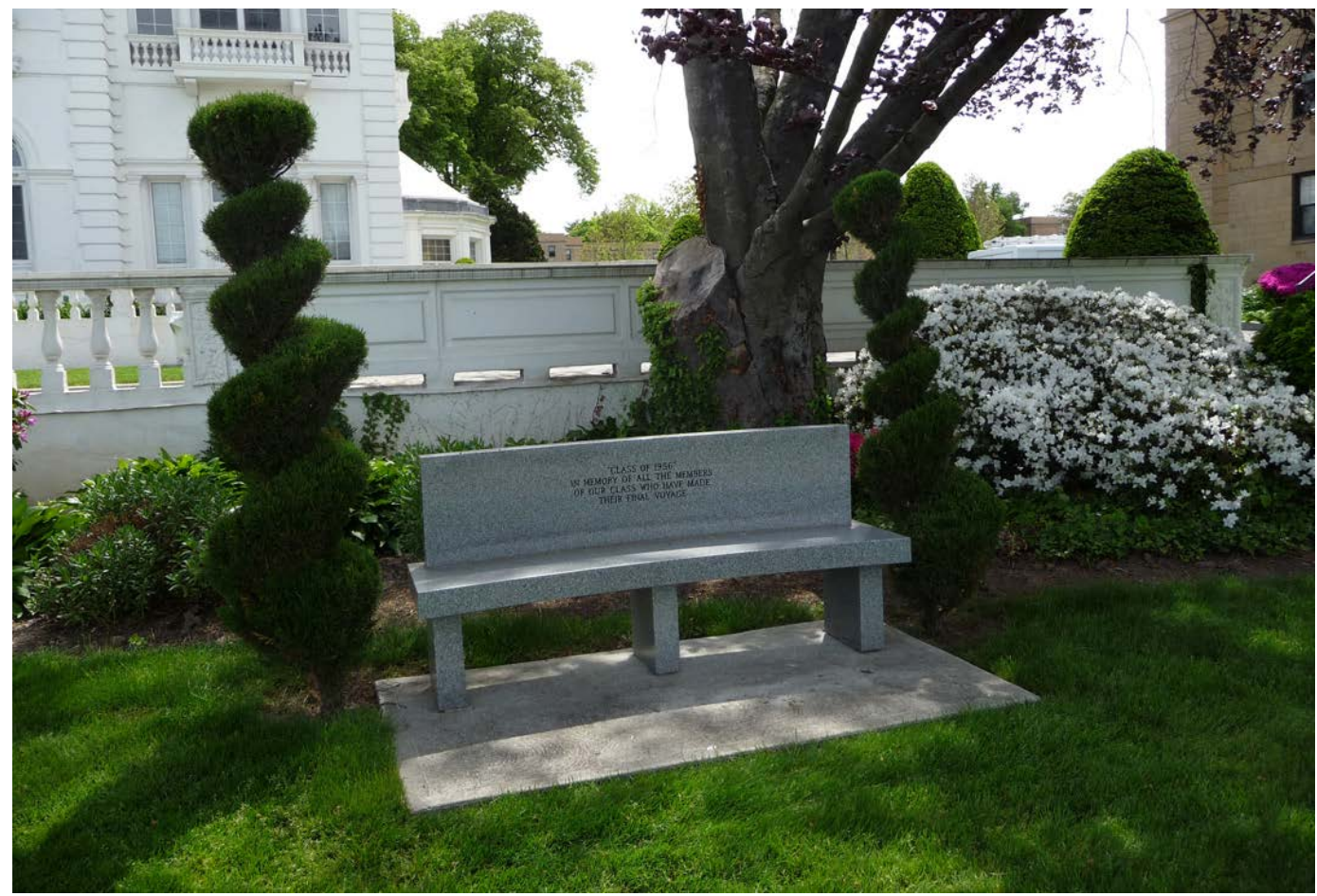

Figure 86. Bench for Class of 1962, presented in 1993 and located in rear of Wiley Hall (ERDC-CERL 2015).

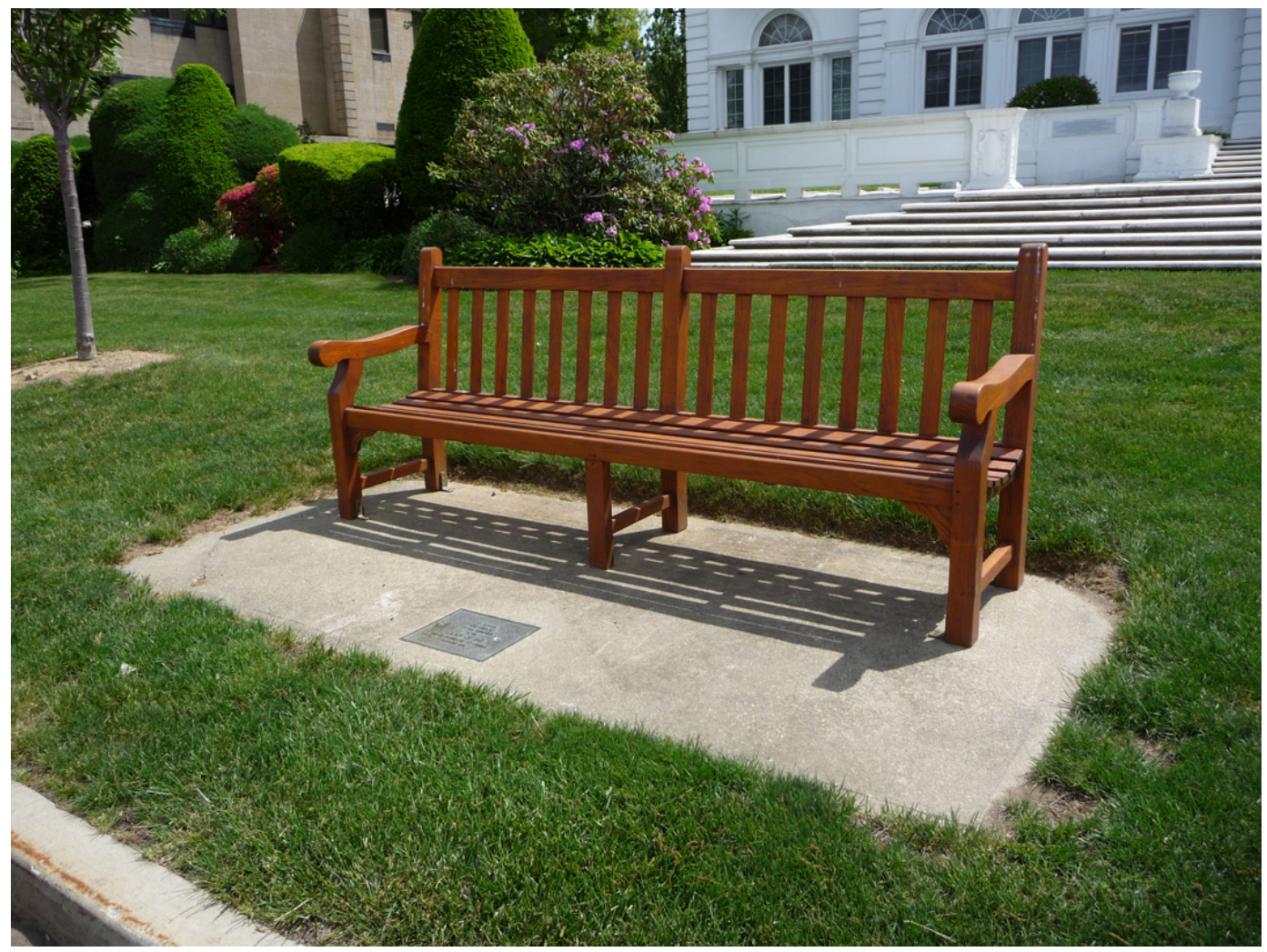




\subsubsection{Other noncontributing small-scale features}

More recent additions to the landscape include benches, picnic tables, bollards, trashcans, and planters (Figure 87-Figure 99). These small-scale features have been added after the periods of significance and are noncontributing.

Figure 87. Bench by waterfront and Eldridge Pool (ERDC-CERL, 2015).

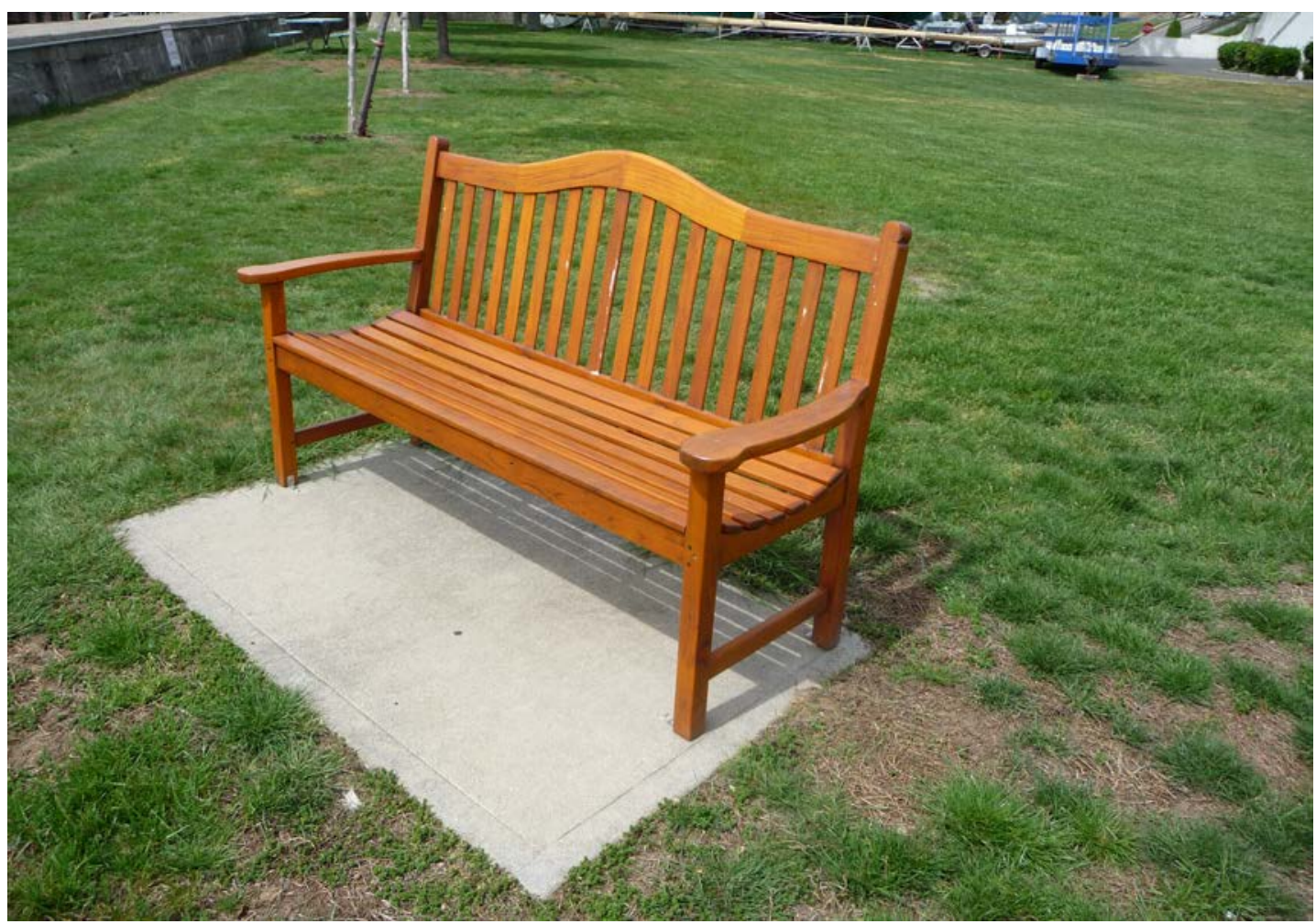


Figure 88. Bench by Vickery Gate (ERDC-CERL, 2015).

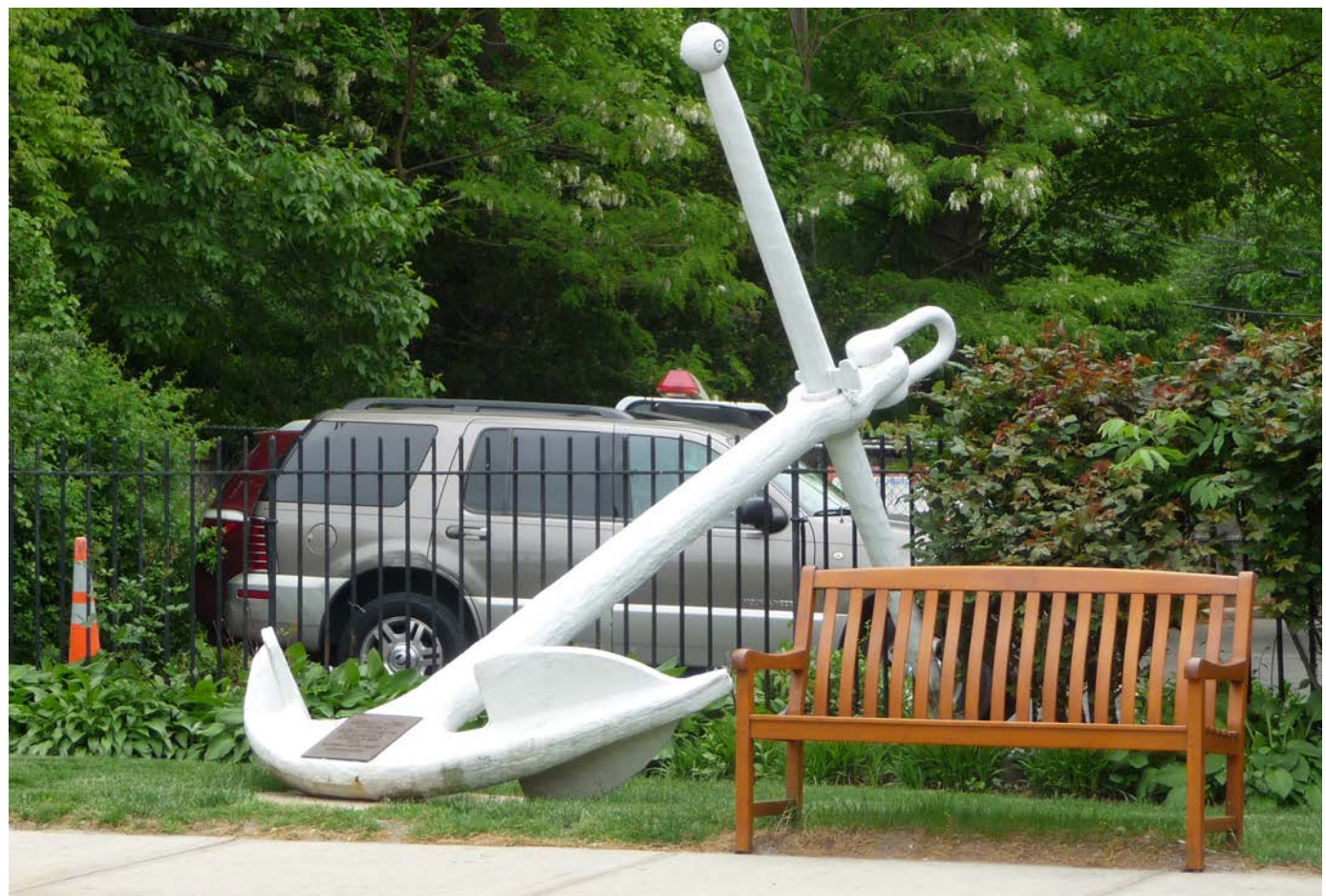

Figure 89. Bench by Melville Hall (ERDC-CERL, 2015).

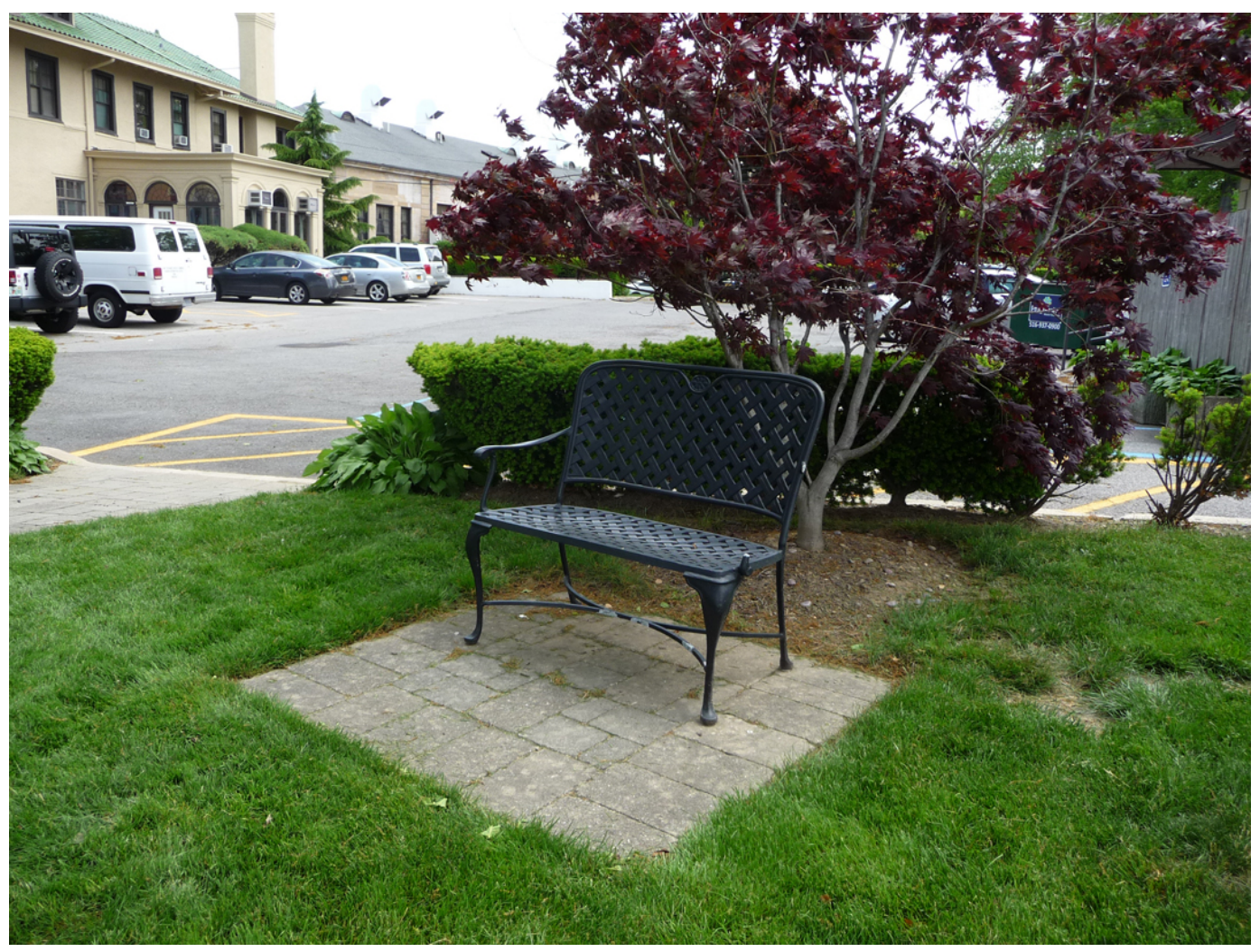


Figure 90. Picnic tables by Land Hall (ERDC-CERL, 2015).

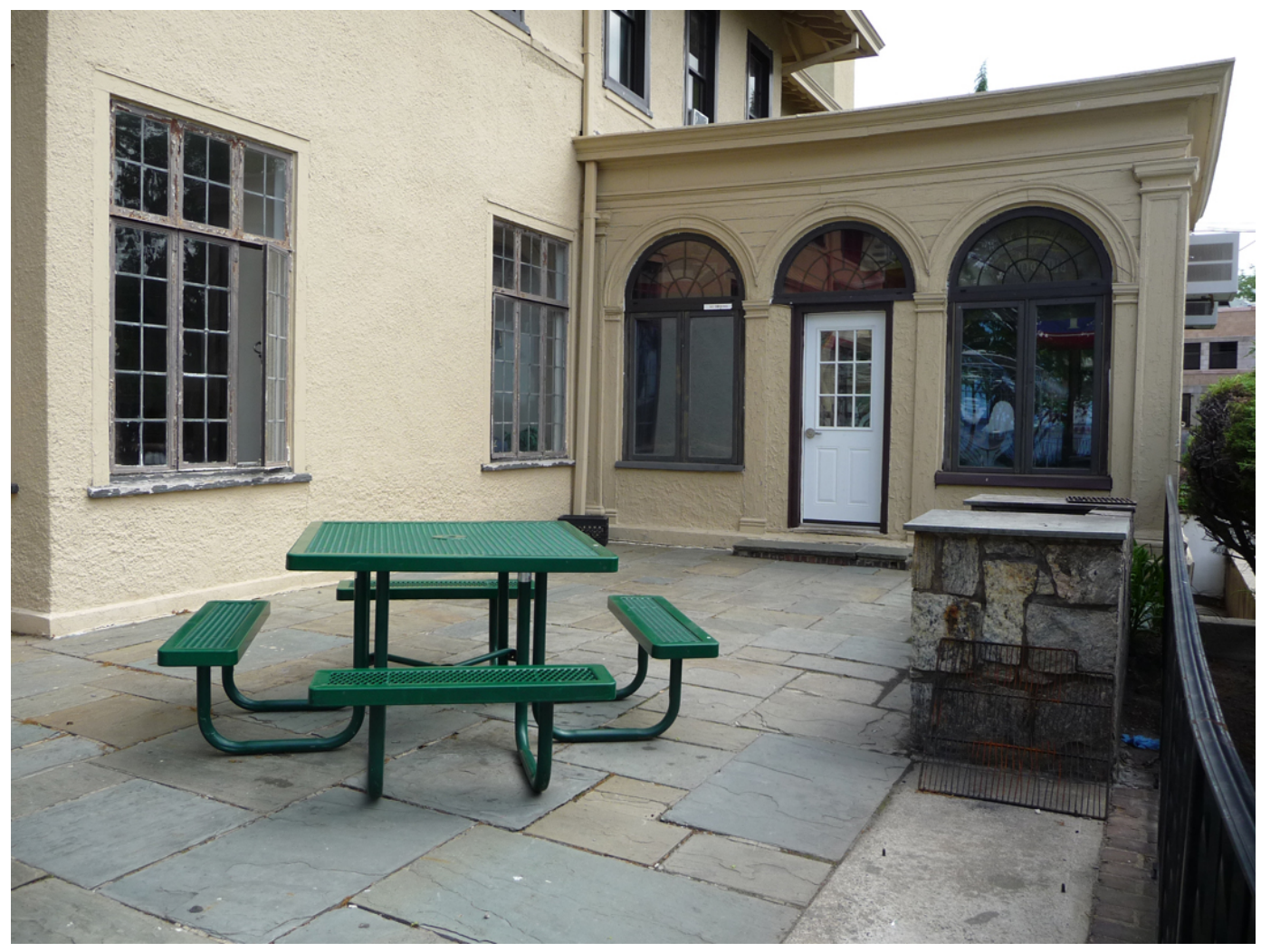

Figure 91. Bollards by Wiley Hall (ERDC-CERL, 2015).

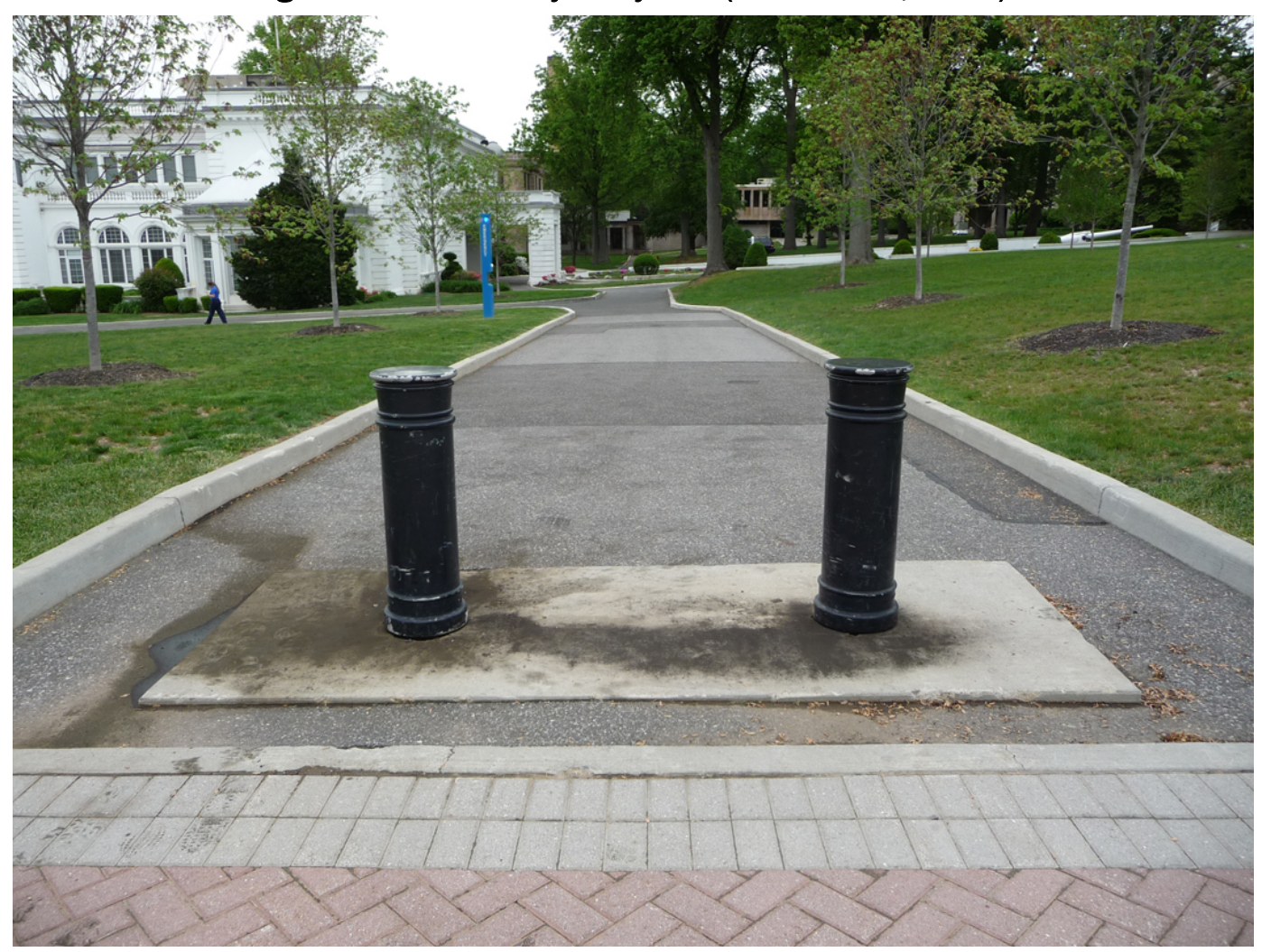


Figure 92. Bollards by flagpole (ERDC-CERL, 2015).

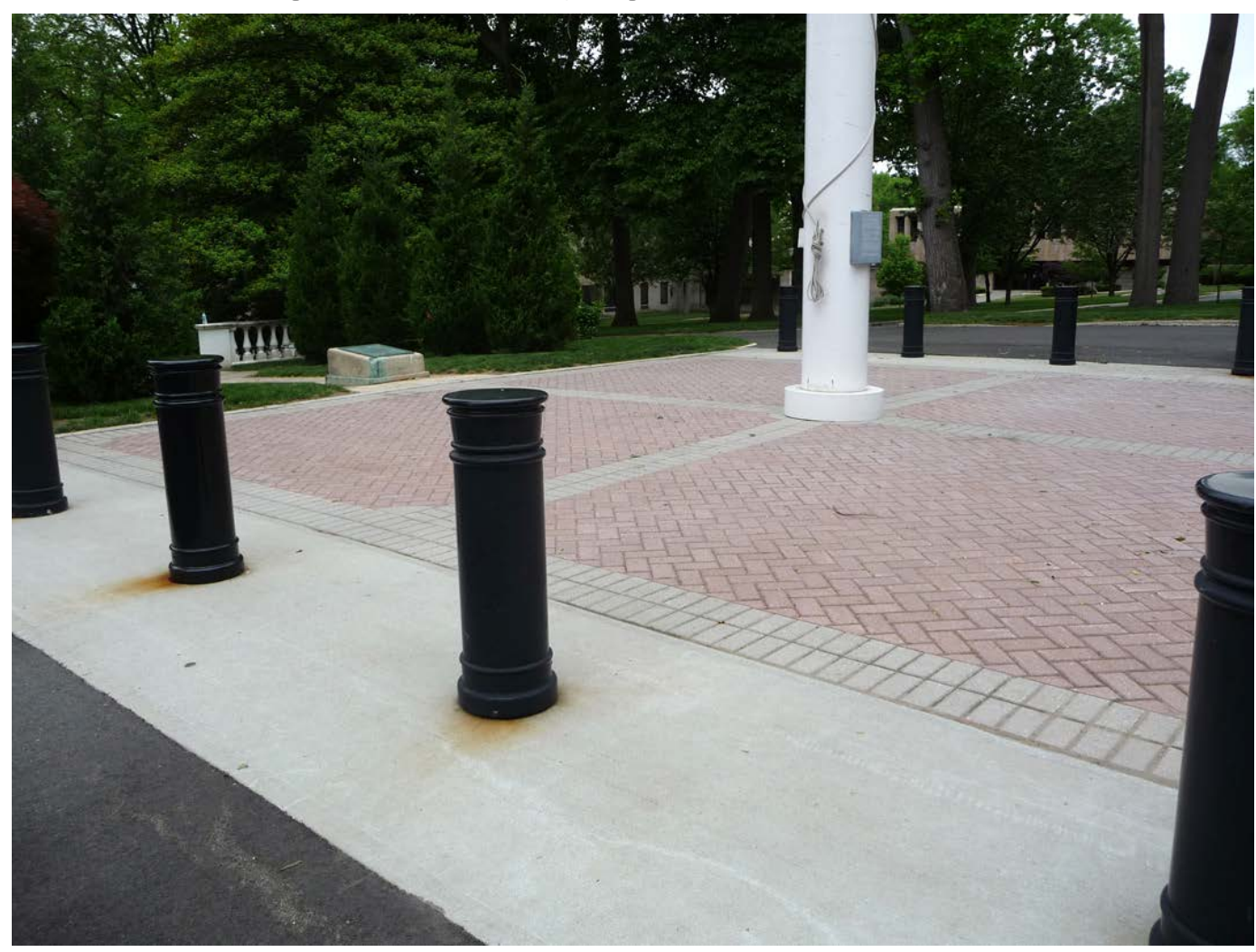

Figure 93. Trash receptacle by Delano Hall (ERDC-CERL, 2015).

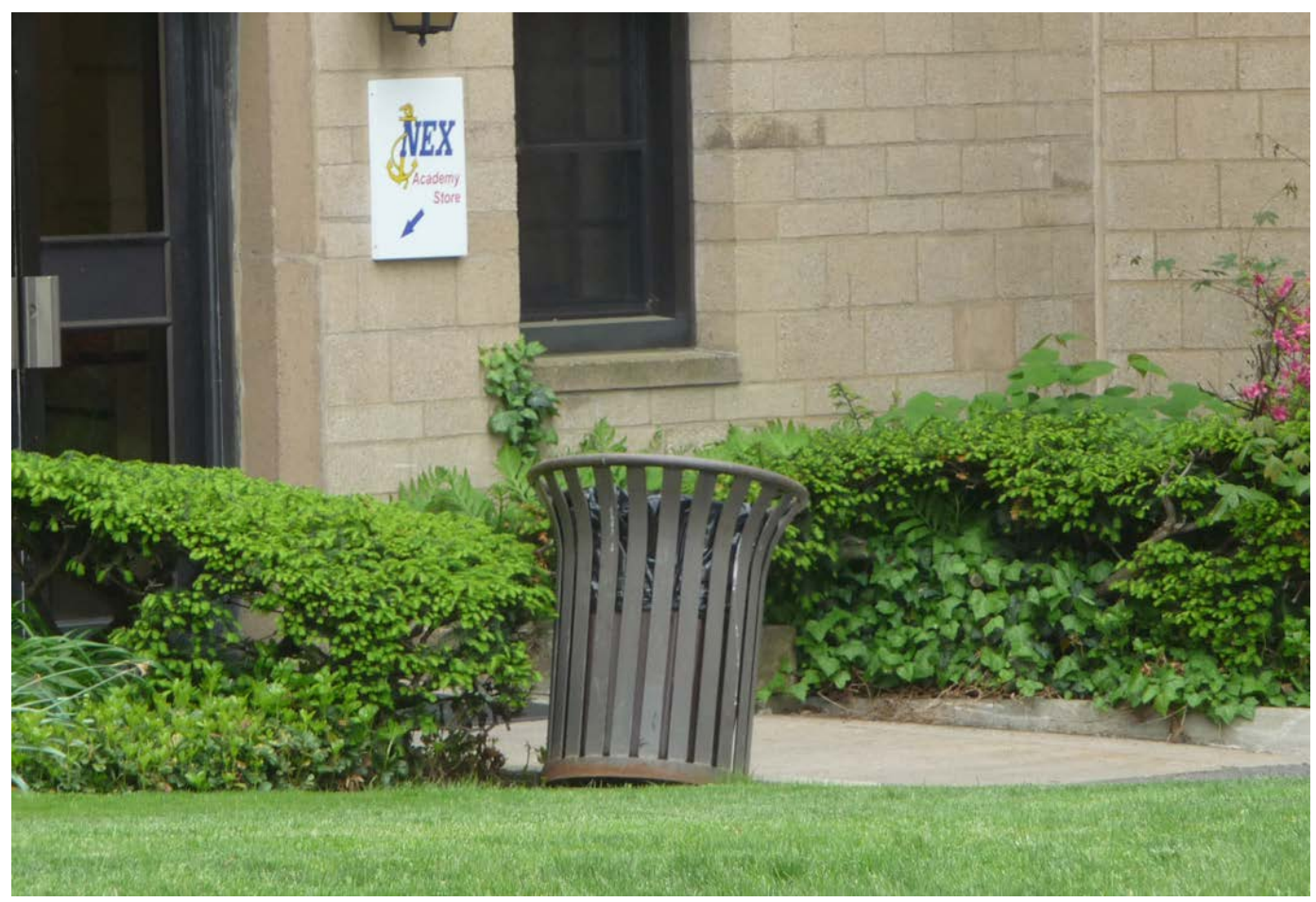


Figure 94. Trash receptacle by Marvin Gate (ERDC-CERL, 2015).

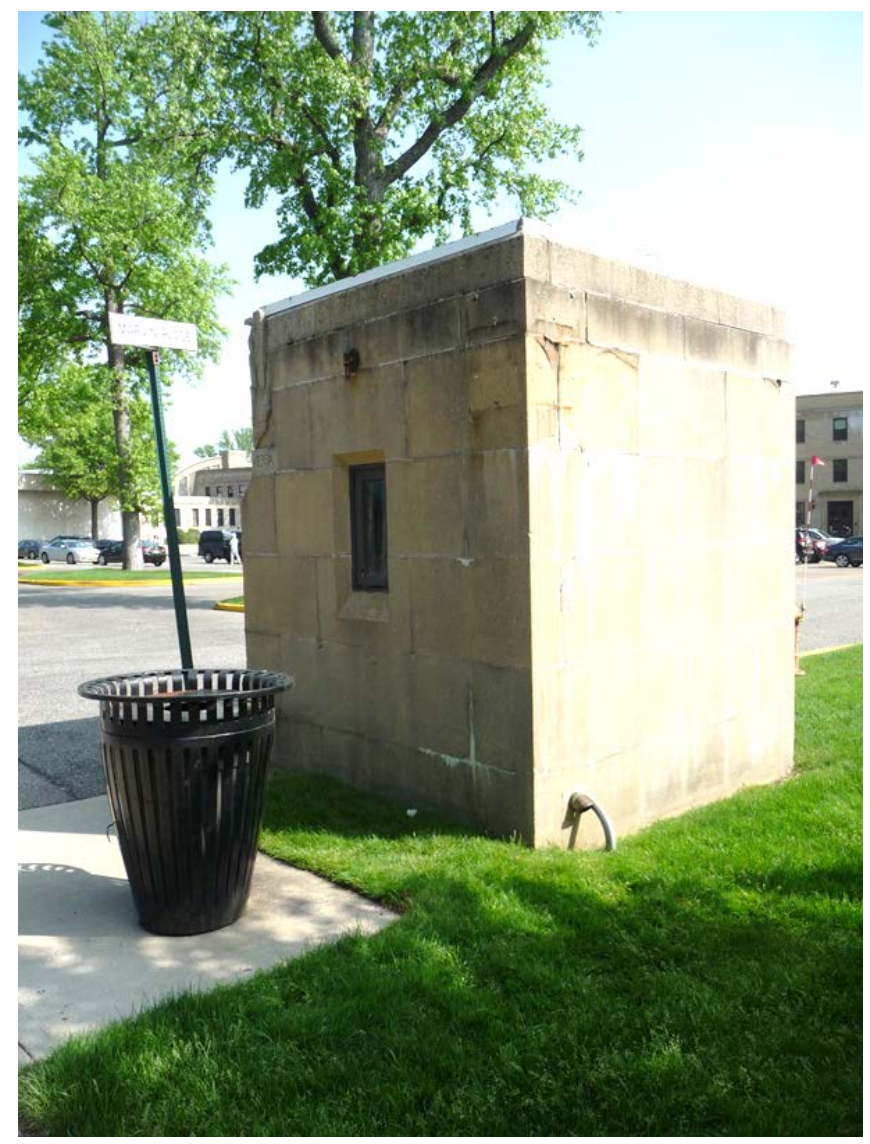

Figure 95 Trash receptacles by Land Hall ERDC-CERL 2015).

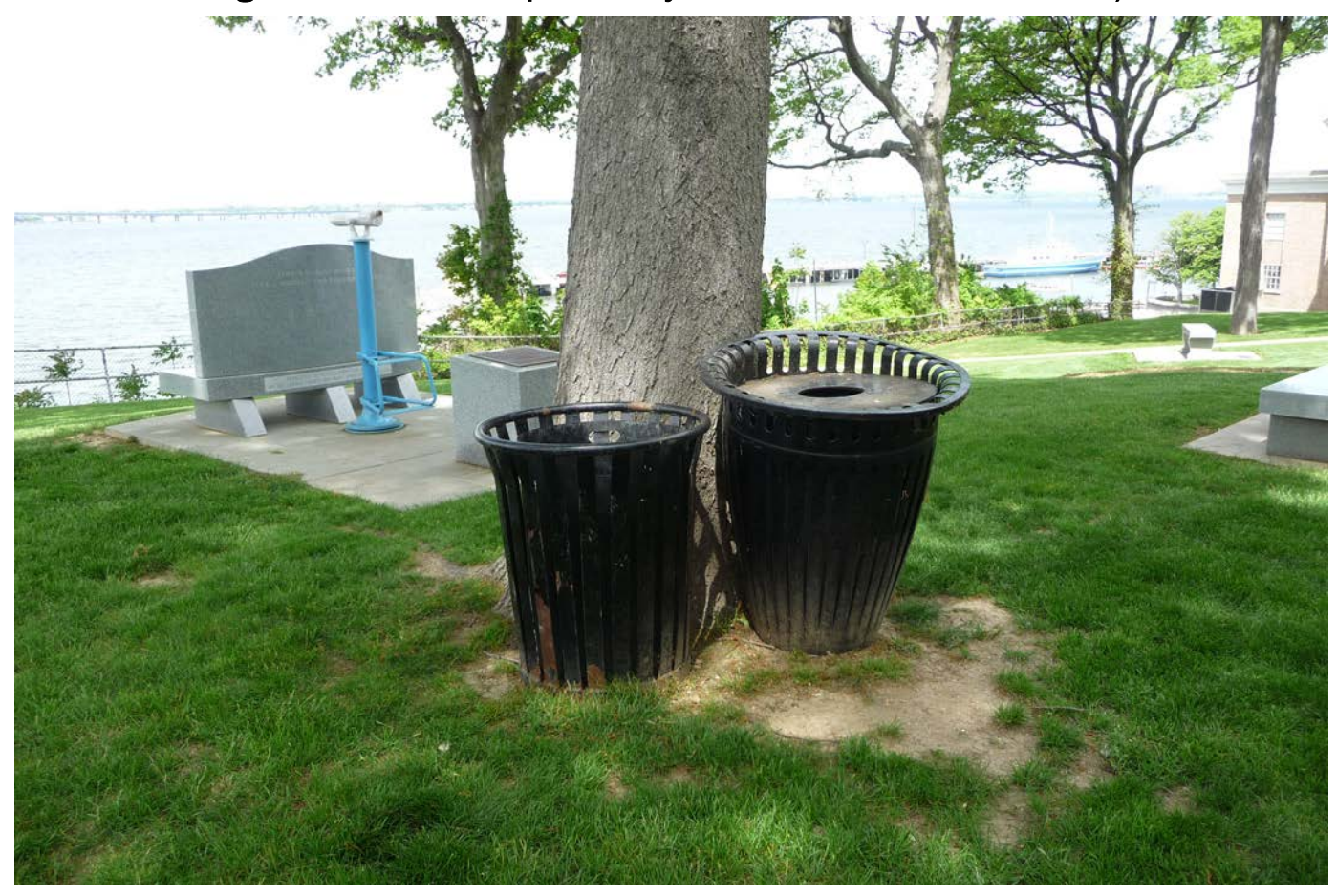


Figure 96. Trash can style by Eldridge Pool (ERDC-CERL, 2015).

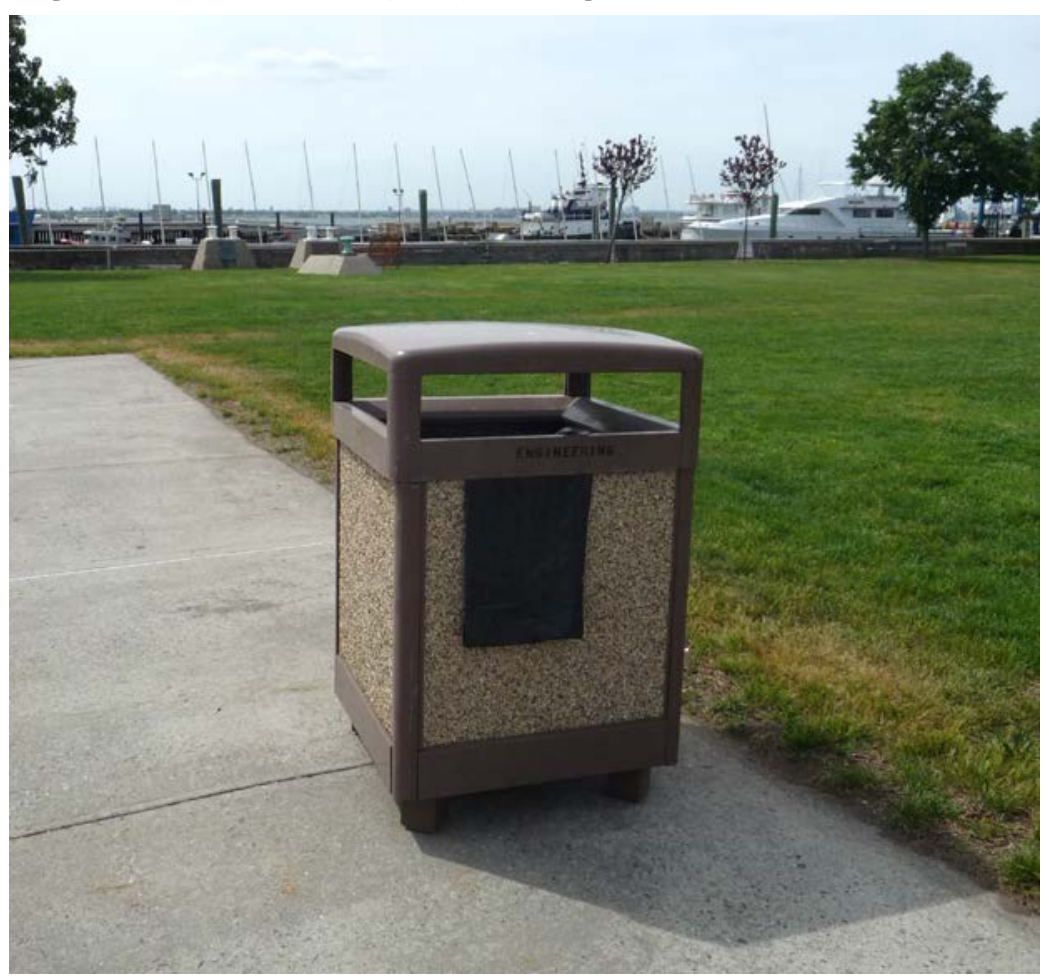

Figure 97. Smoking receptacle in front of Samuels Hall (ERDC-CERL, 2015).

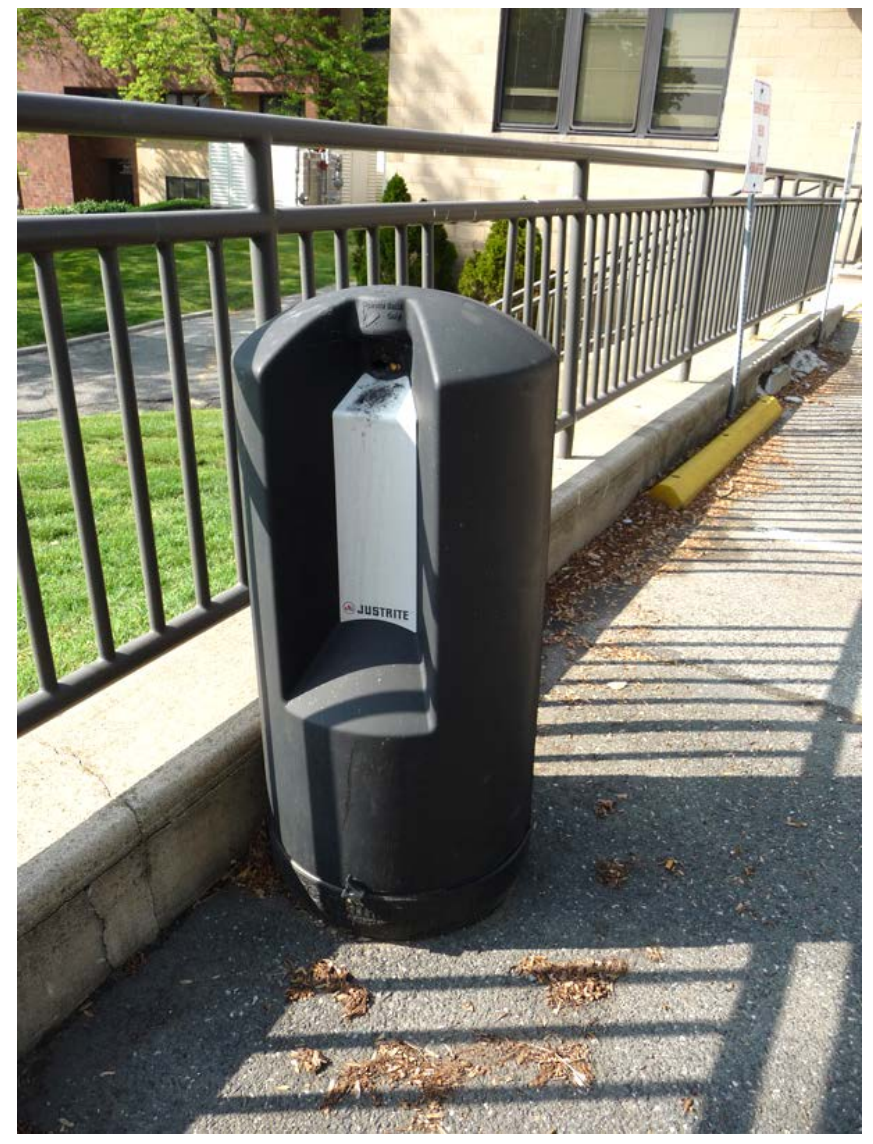


Figure 98. Planter by O’Hara Hall (ERDC-CERL, 2015).

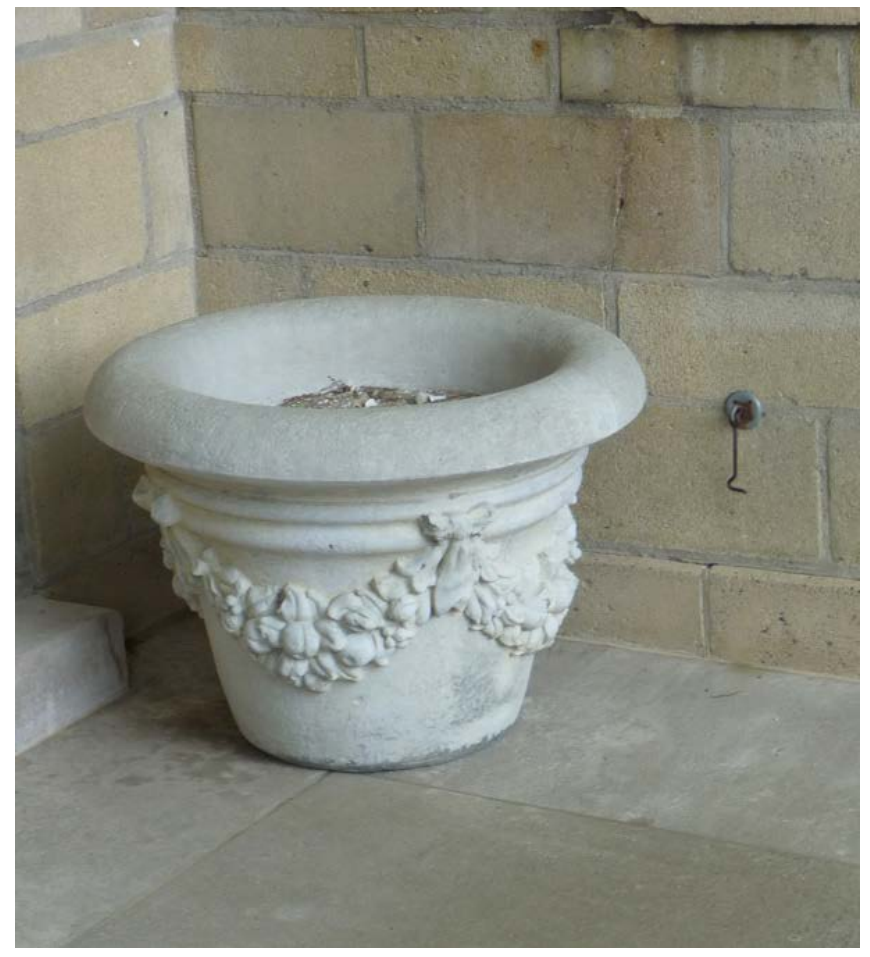

Figure 99. Planter by Furuseth Hall (ERDC-CERL, 2015).

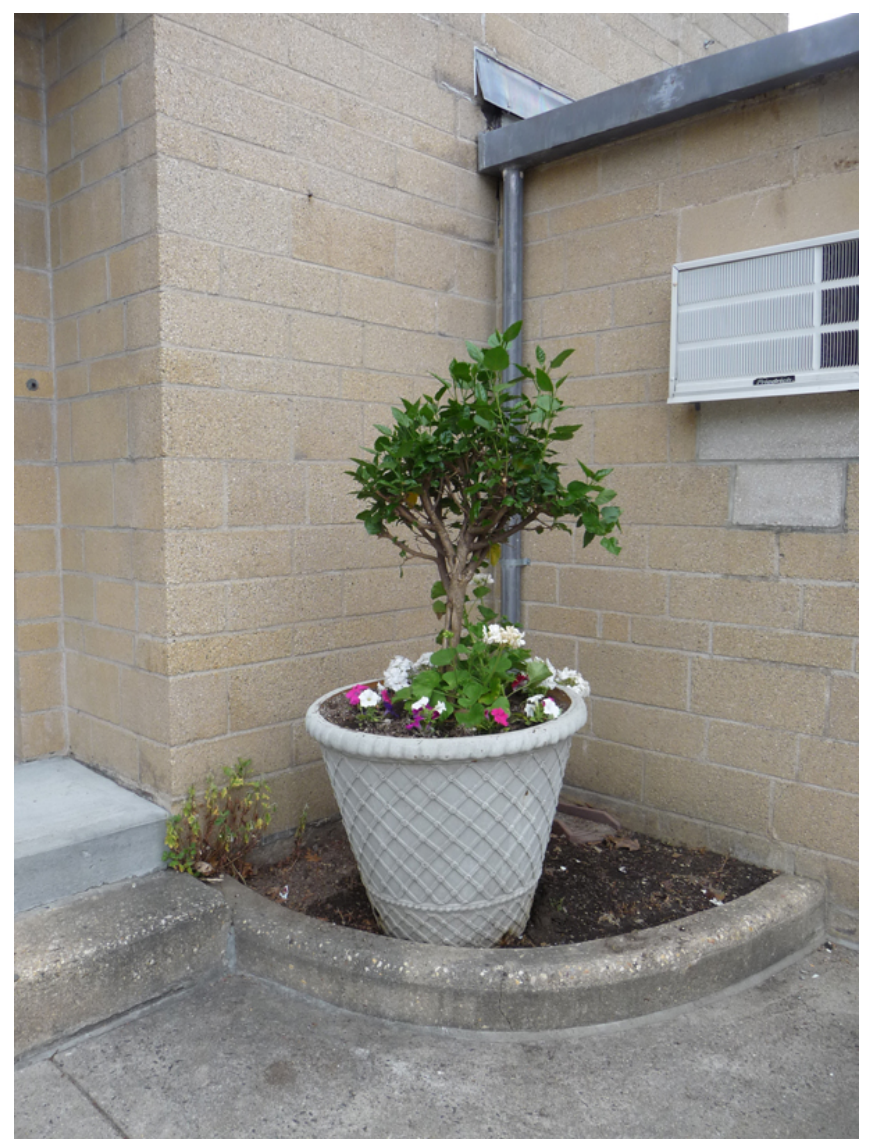




\subsubsection{Views and viewsheds}

The terraced landscape of the former Chrysler mansion contributes both to the views toward the Long Island Sound and the views from the Sound toward the Academy. In addition, the axial layout of the Academy creates views across the quadrangle in four directions. Views to the water and to Long Island Sound were historically a large part of the design of Gold Coast-era homes and estates. The estates' formal gardens were laid out to be visible from the houses, and some were visible to anyone driving onto the property.

\subsubsection{View from Wiley Hall to water}

This view includes not only the blue water and passing ships, but also the terraced landscape, the grassy open space, the pool, and the docks and boats (Figure 100-Figure 102). This entire landscape was designed for entertaining, parties, and the view.

Figure 100. View from Chrysler terrace in real estate advertisement, 1941 (American Merchant Marine Museum).

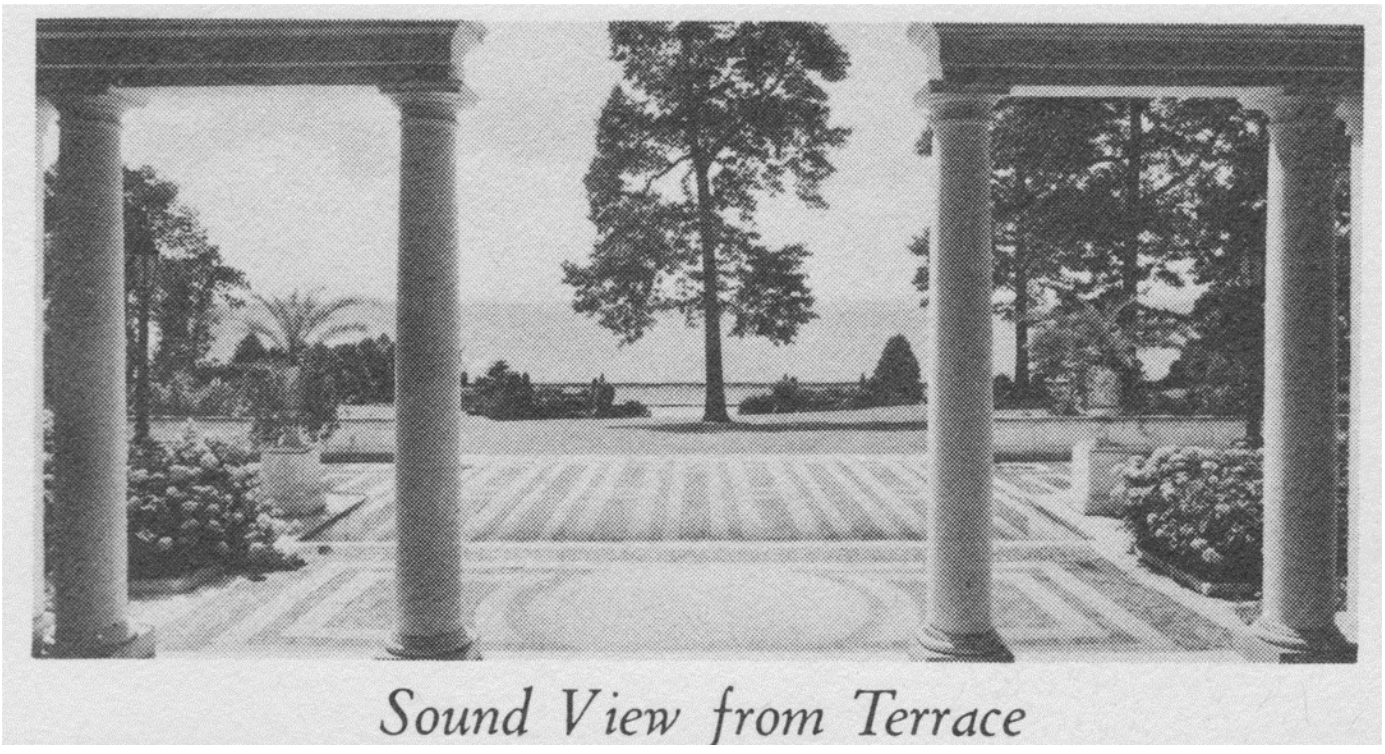


Figure 101. View from Wiley Hall to sound, 1943 (USMAA Bland Library).

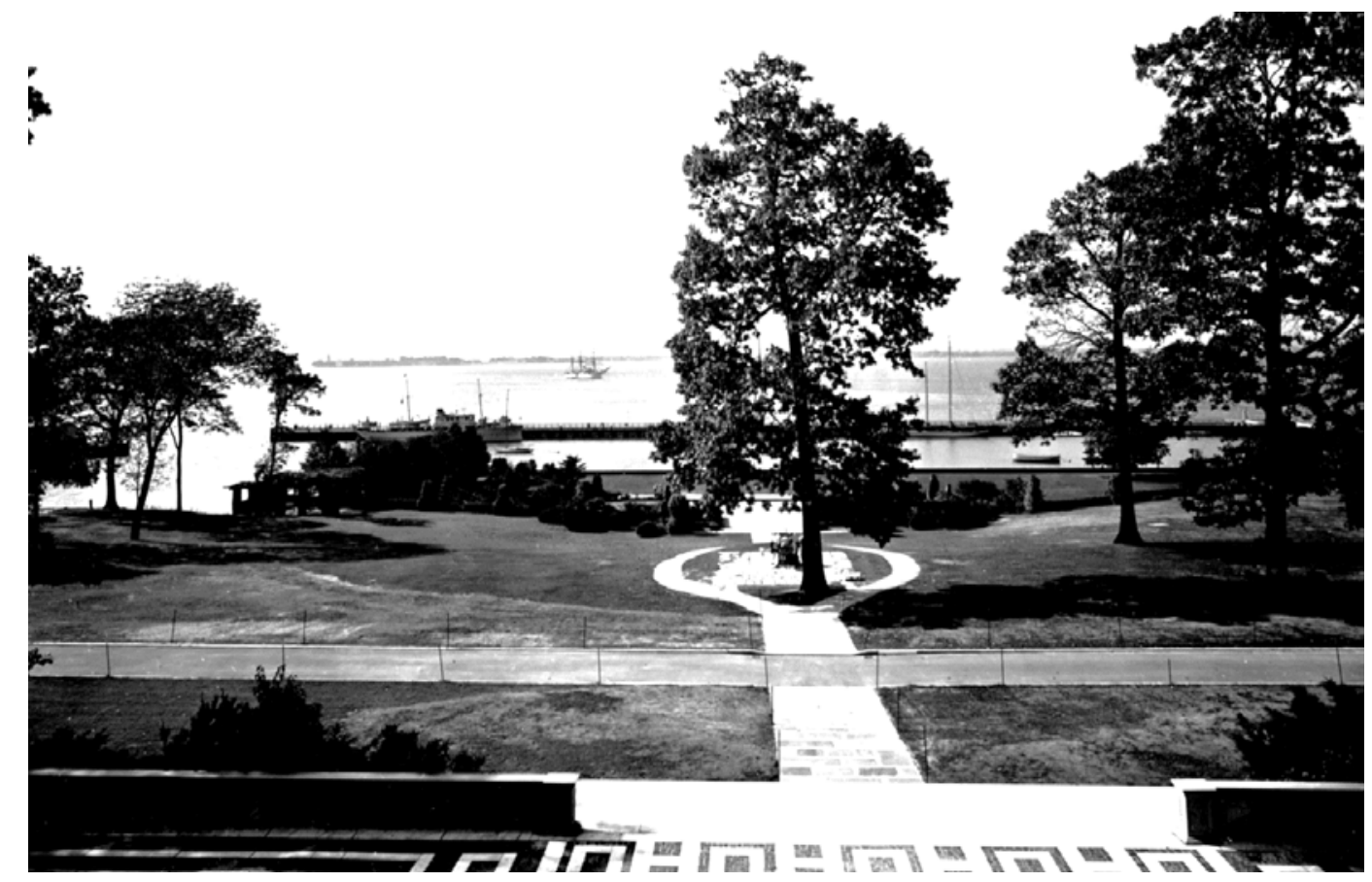

Figure 102. View from terraces of Wiley Hall to Long Island Sound (ERDC-CERL, 2015).

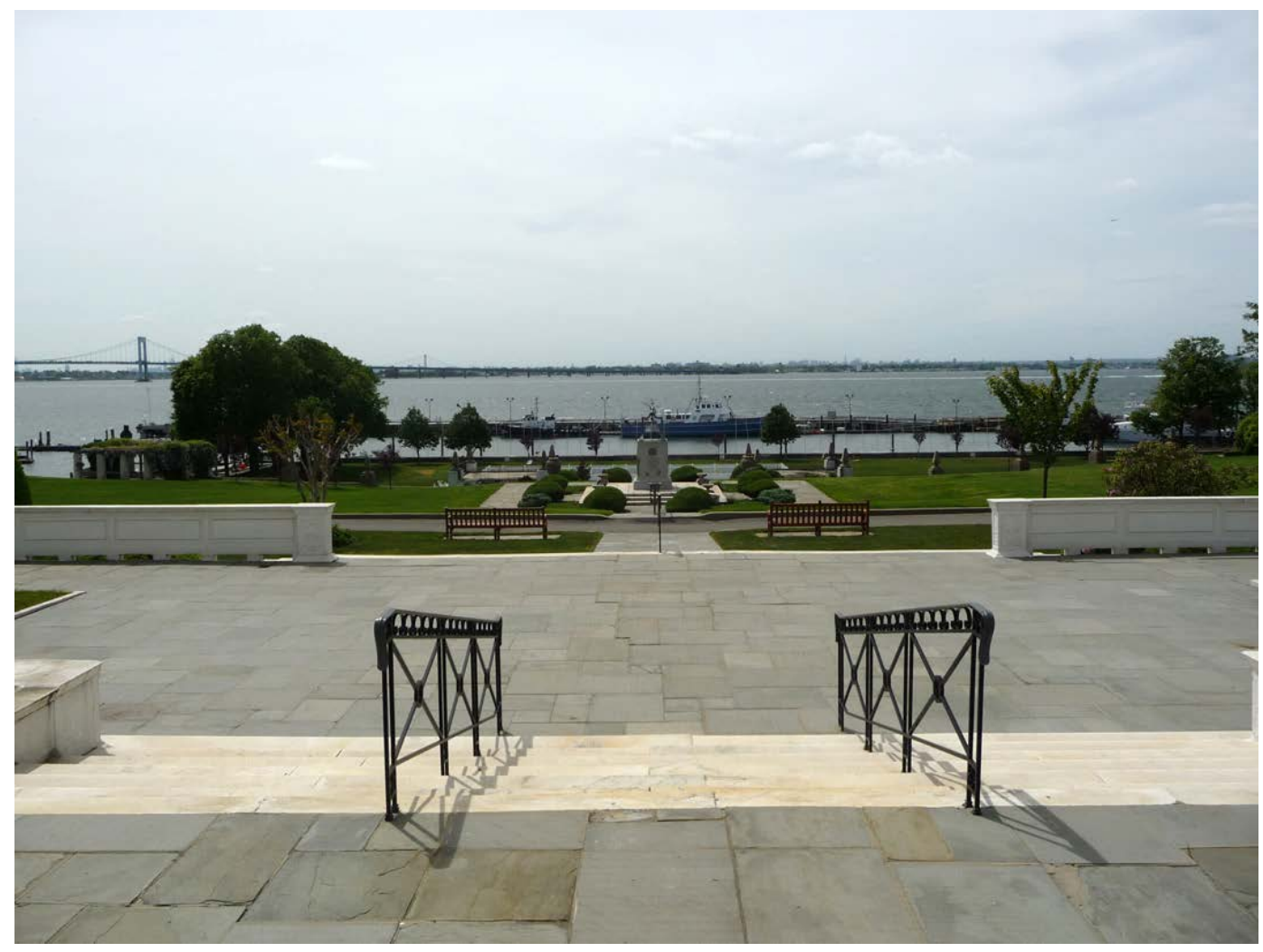




\subsubsection{View from water to Wiley Hall}

In an area when many residents owned boats and/or travelled by steamboat, the views from the water were important characteristics of the Gold Coast estates (e.g., Figure 103-Figure 105).

Figure 103. View to Chrysler mansion from water, 1941 (USMMA Bland Library).

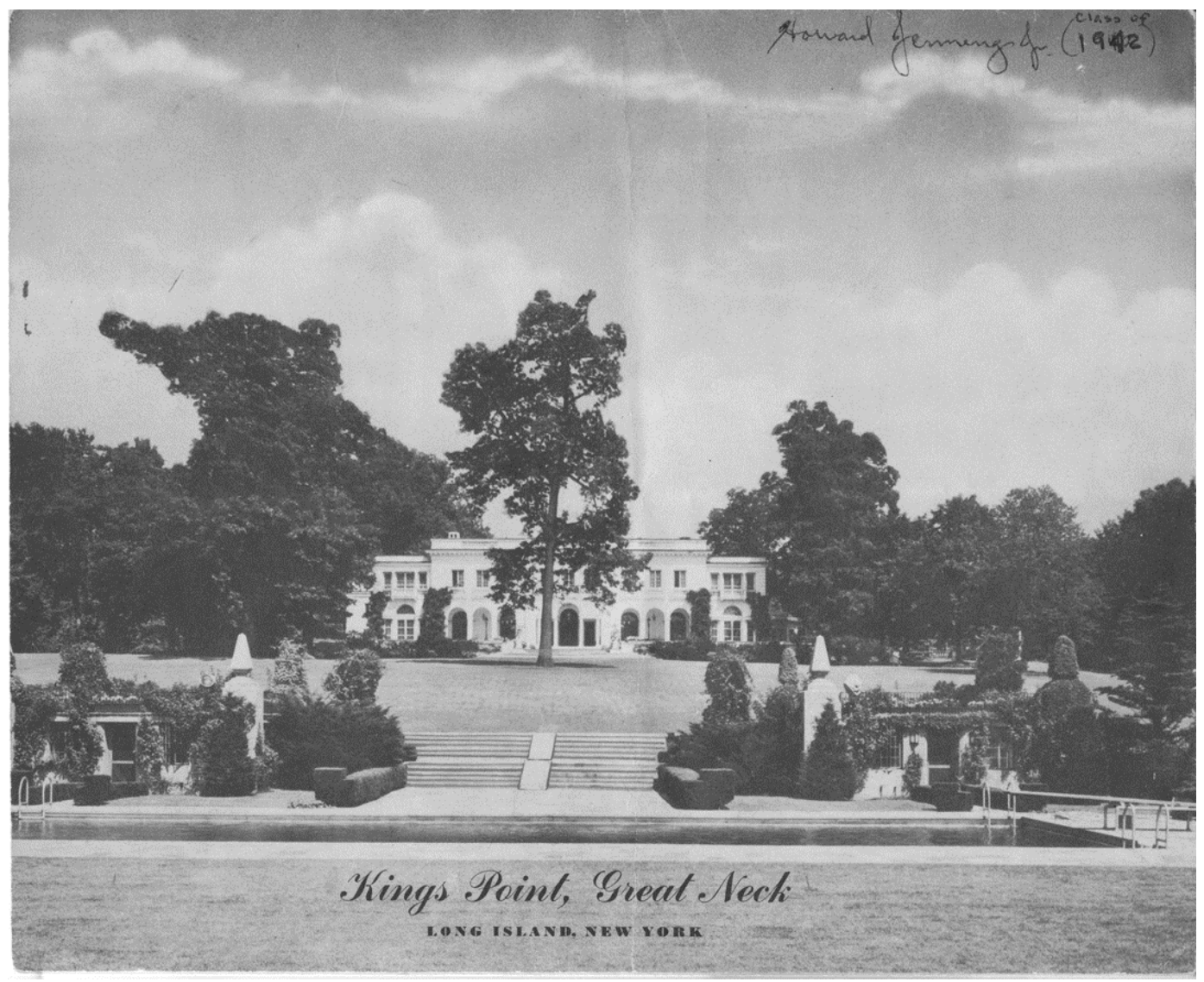


Figure 104. View to Wiley Hall from waterfront, 1943, after Academy's establishment (USMMA Bland Library).

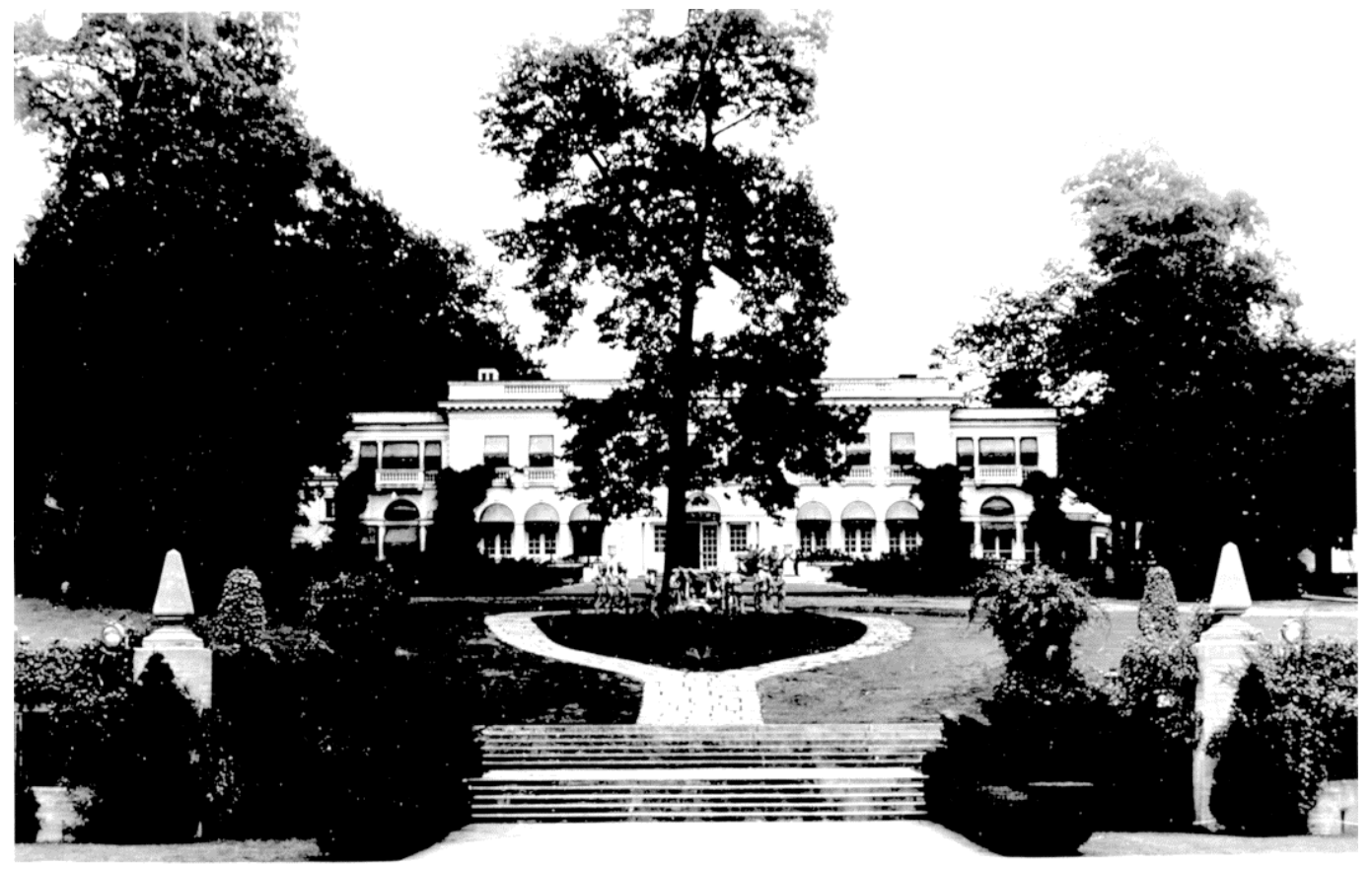

Figure 105. View to Wiley Hall from waterfront (ERDC-CERL, 2015).

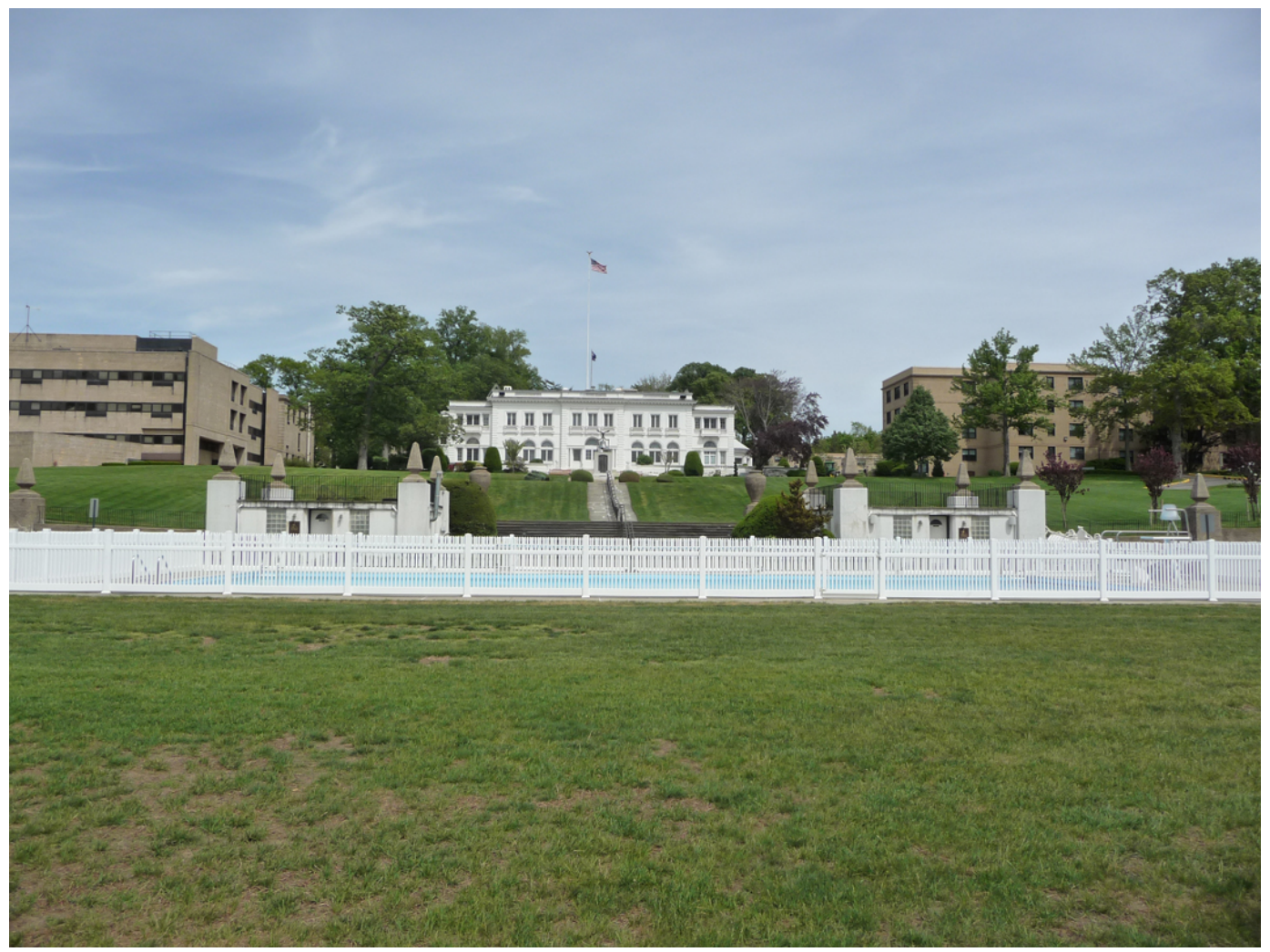




\subsubsection{Axial views from Wiley Hall to Truxton Arcade}

The design of the Academy was strongly based on a formal, axial relationship between Wiley Hall and formal gardens (Powell Oval), the flagpole, the Amphitrite Pool, the Truxton Arcade (Barry and Jones Halls), and the entrance to O'Hara Hall (Figure 106-Figure 109).

Figure 106. View of Amphitrite Pool and Truxton Arcade, 1942 (USMMA Bland Library).

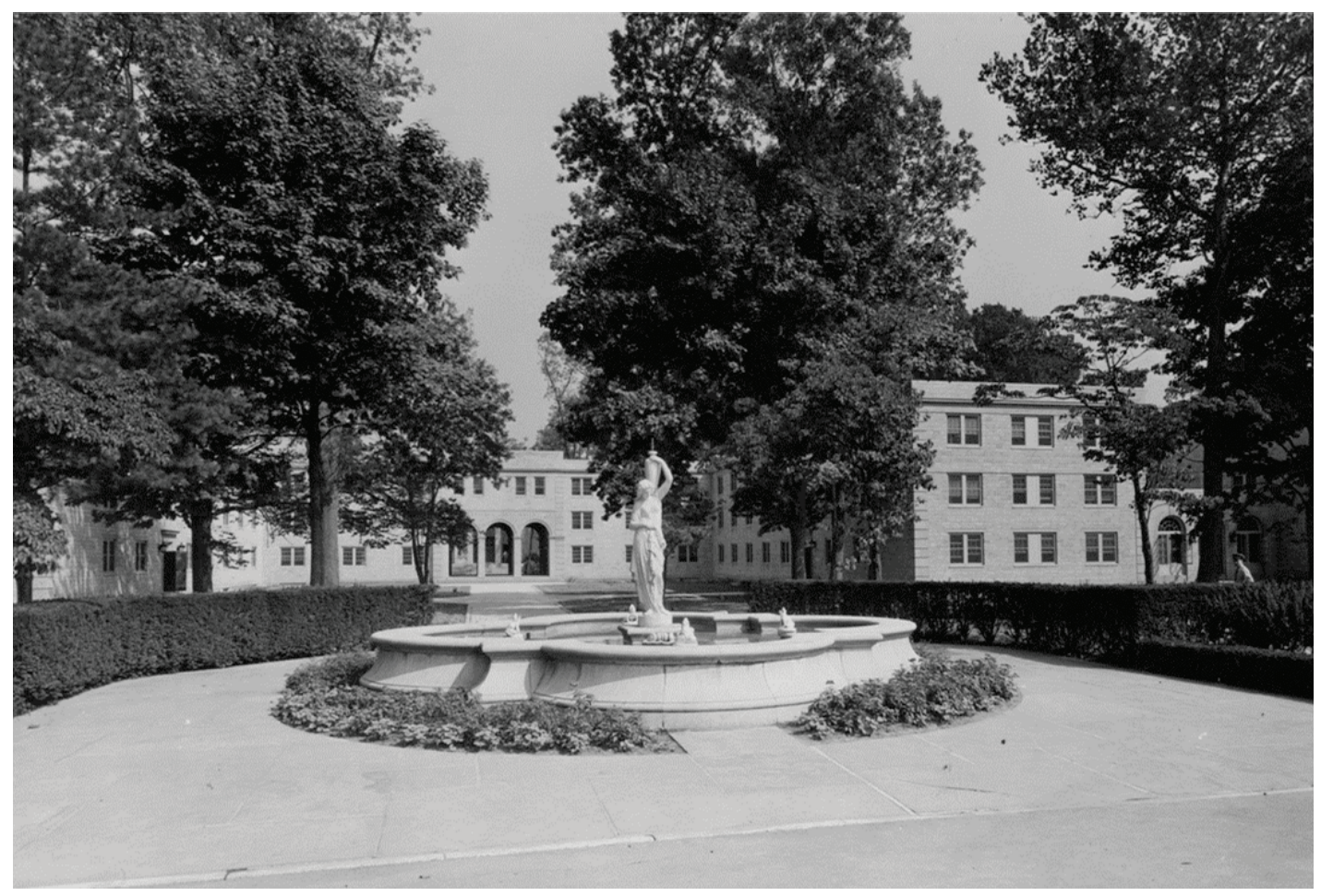


Figure 107. View of Amphitrite Pool and Truxton Arcade (ERDC-CERL, 2015).

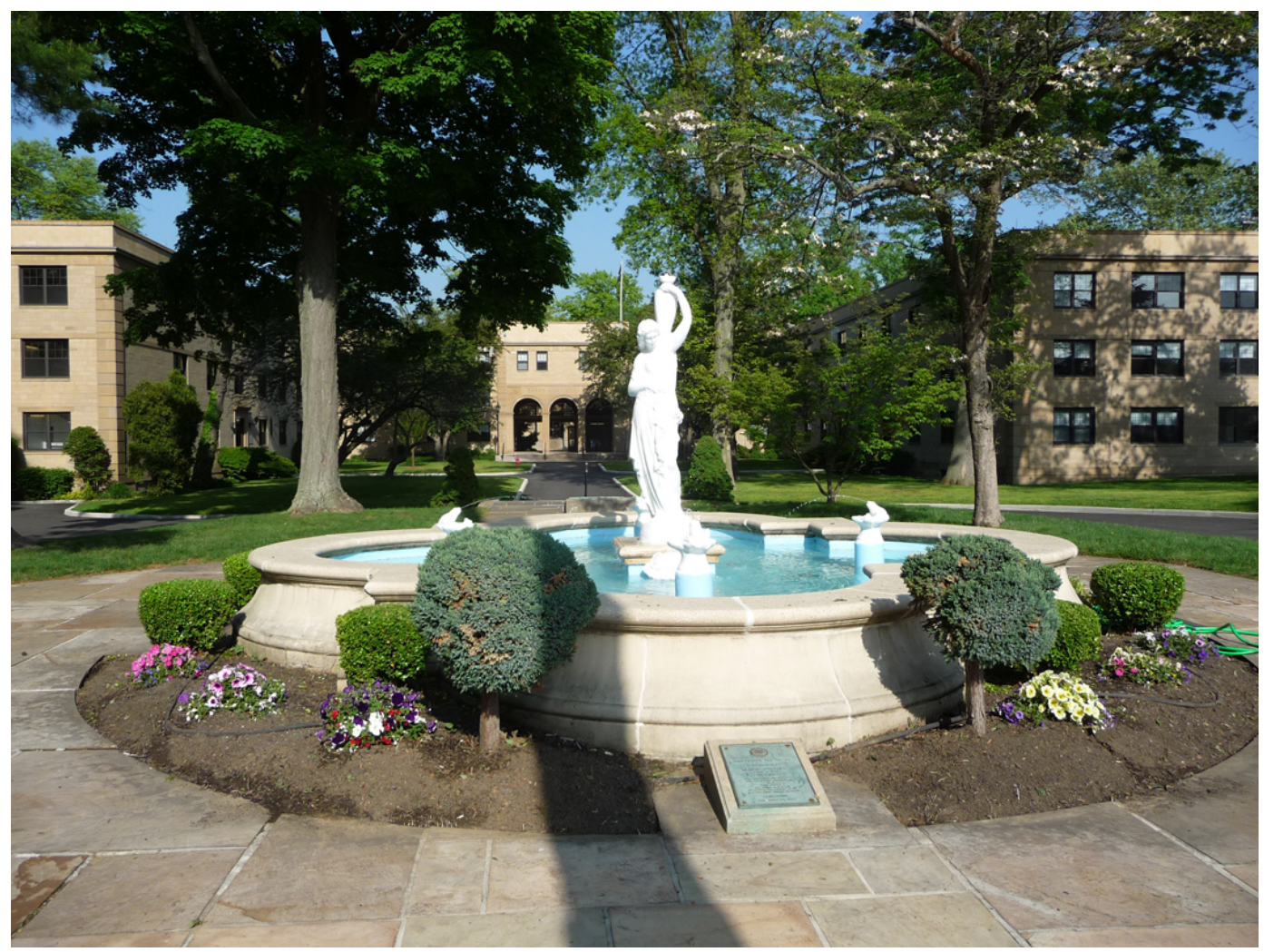

Figure 108. View of Truxton Arcade from Amphitrite Pool, 1943 (USMMA Bland Library).

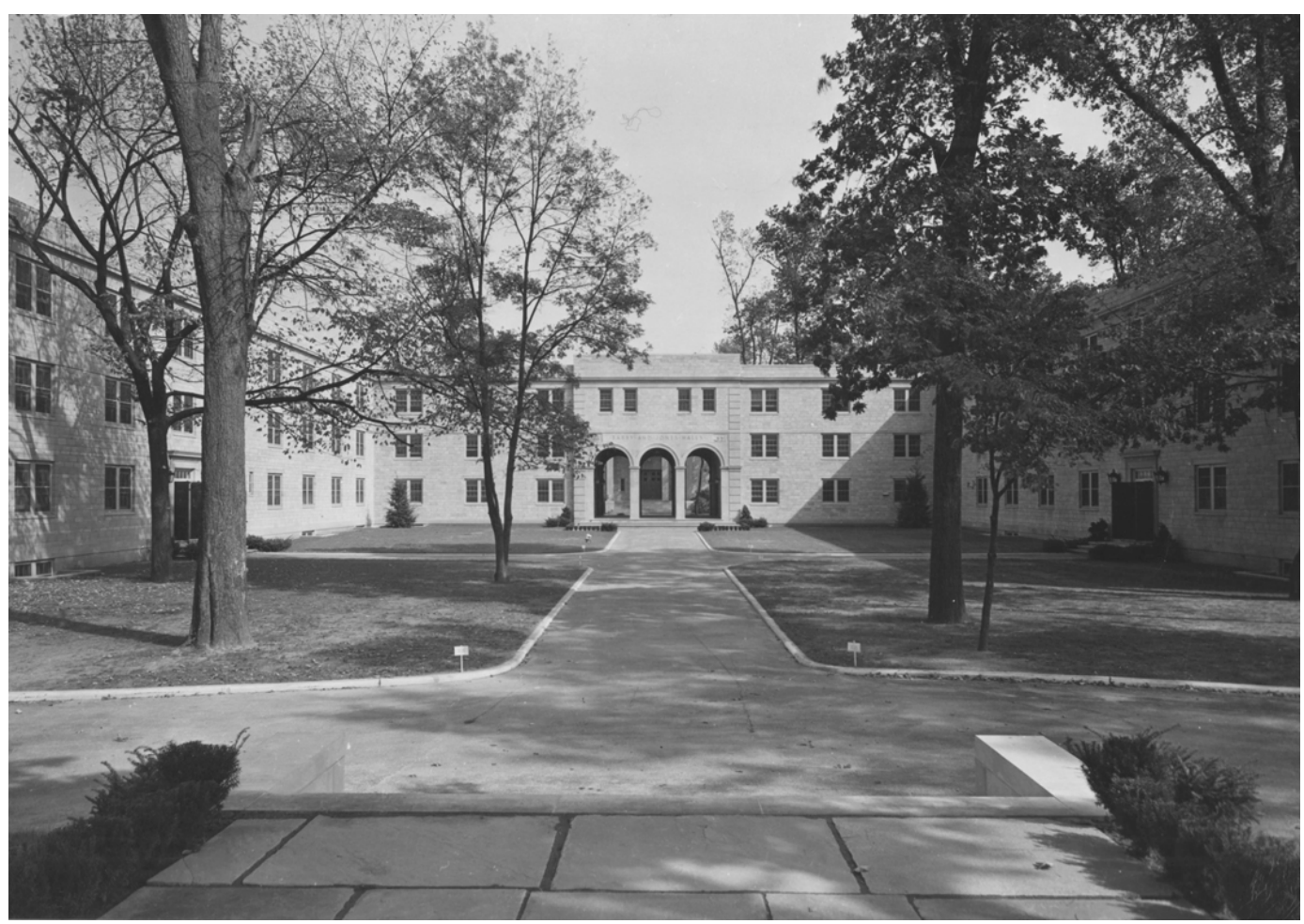


Figure 109. View of Truxton Arcade from Amphitrite Pool (ERDC-CERL, 2015).

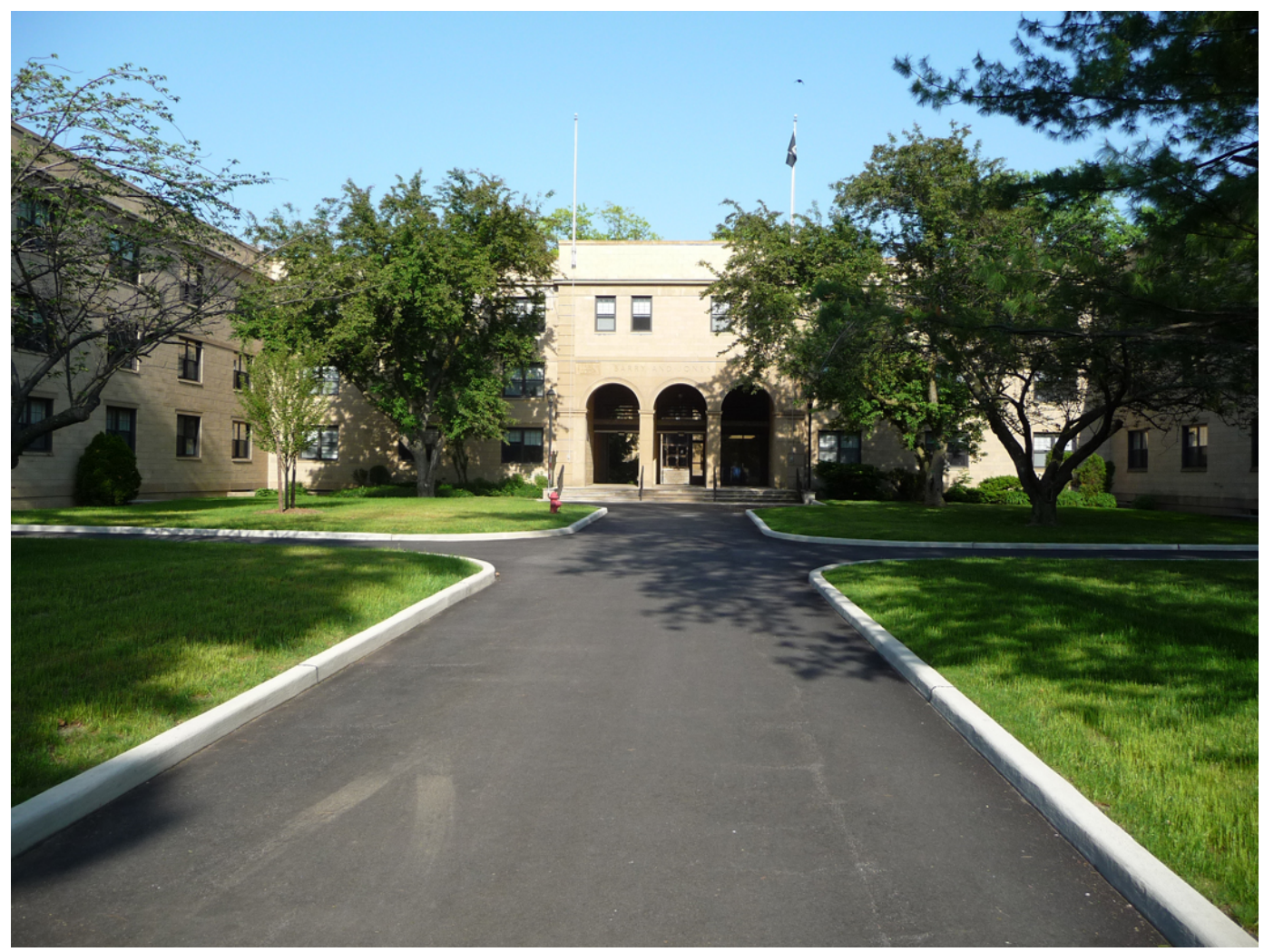

\subsubsection{Axial views from Truxton Arcade to Wiley Hall}

The design of the Academy was strongly based on a formal, axial relationship between Wiley Hall and formal gardens (Powell Hall), the flagpole, the Amphitrite Pool, the Truxton Arcade (connecting Barry and Jones Halls), and the entrance to O'Hara Hall (Figure 110-Figure 114). 
Figure 110. View from Truxton Arcade toward flagpole and Wiley Hall, date unknown (USMMA Bland Library).

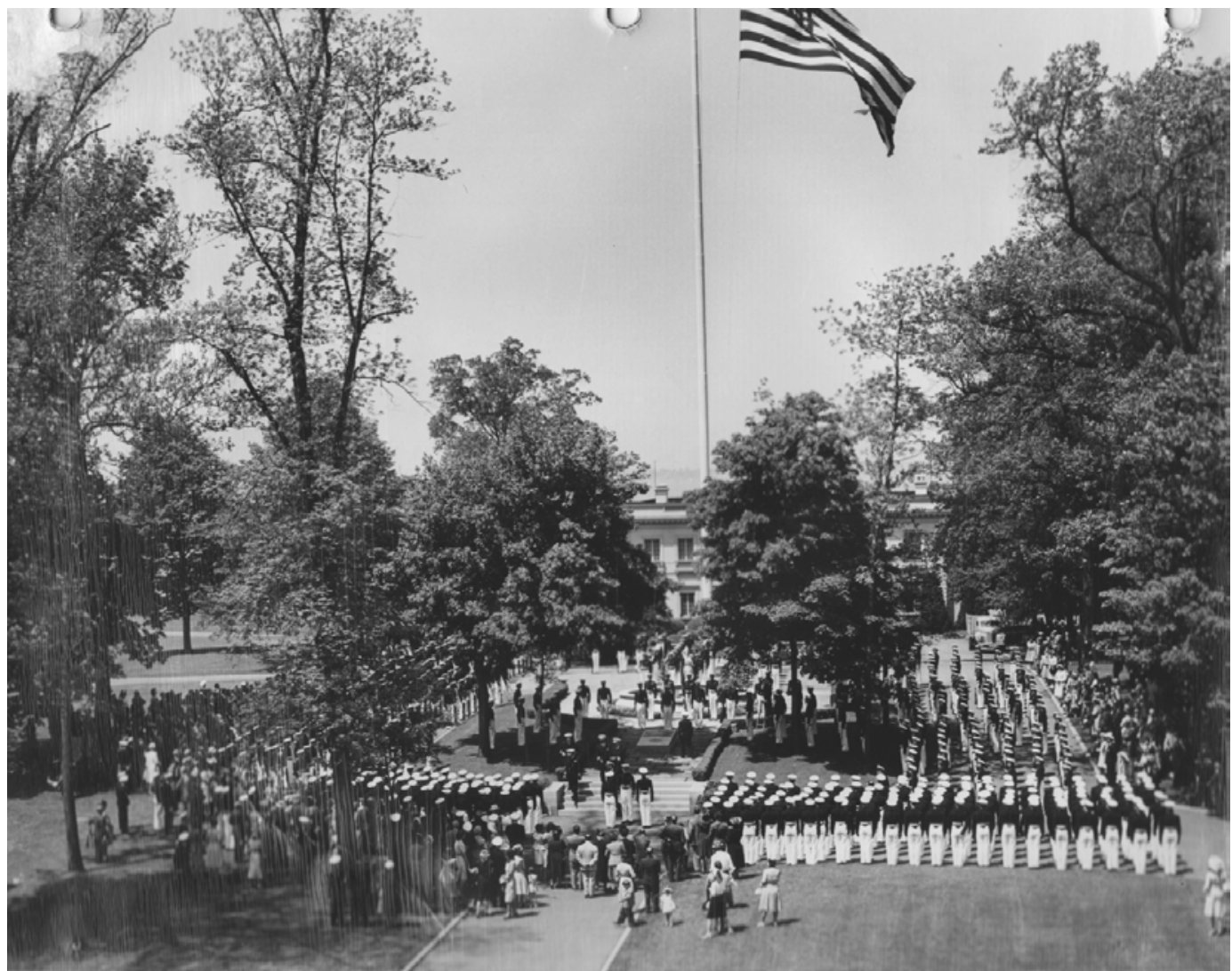


Figure 111. View from Truxton Arcade toward flagpole and Wiley Hall (ERDC-CERL, 2013).

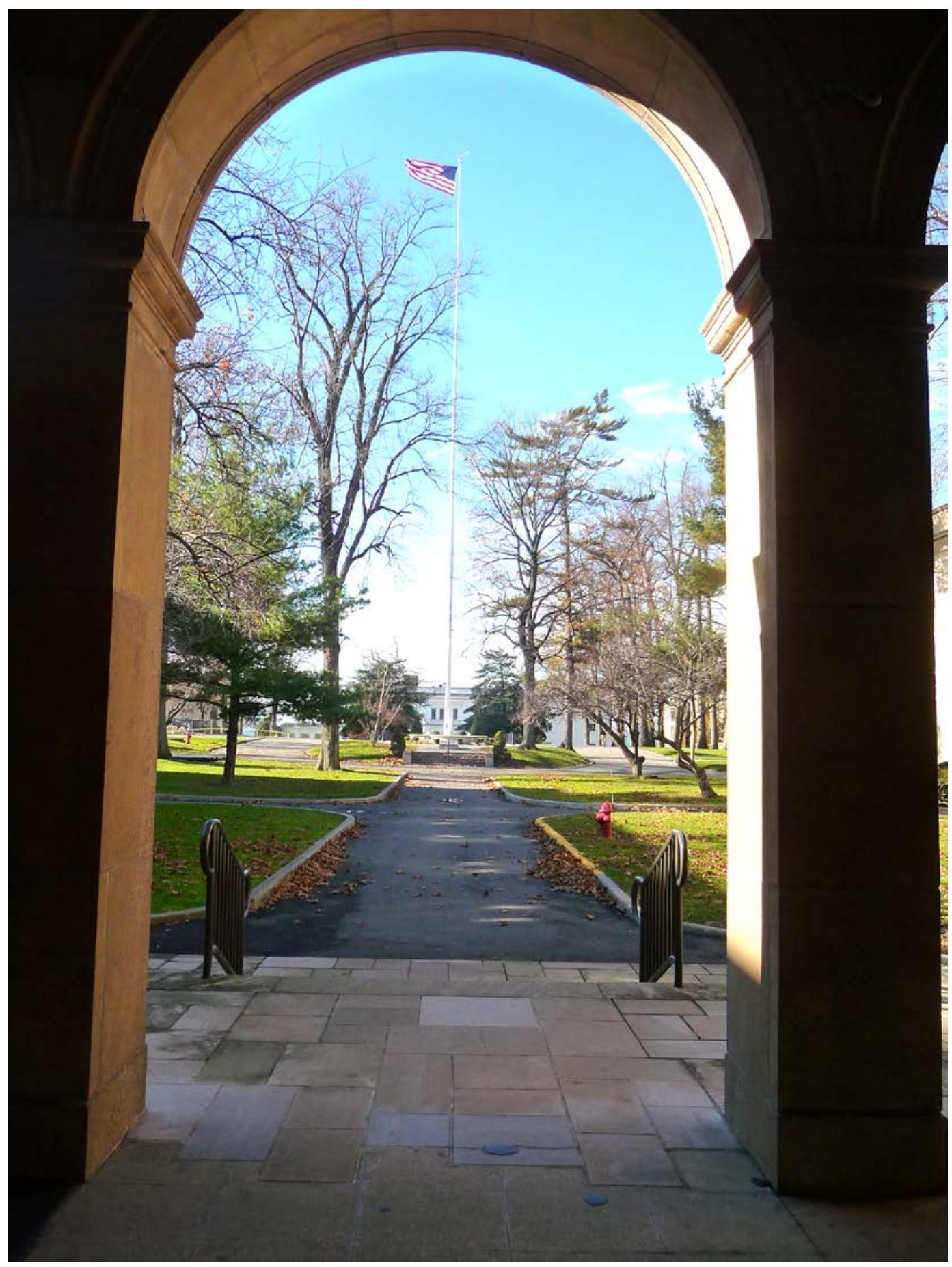


Figure 112. View through Truxton Arcade toward Amphitrite Pool, flagpole and Wiley Hall (ERDC-CERL, 2015).

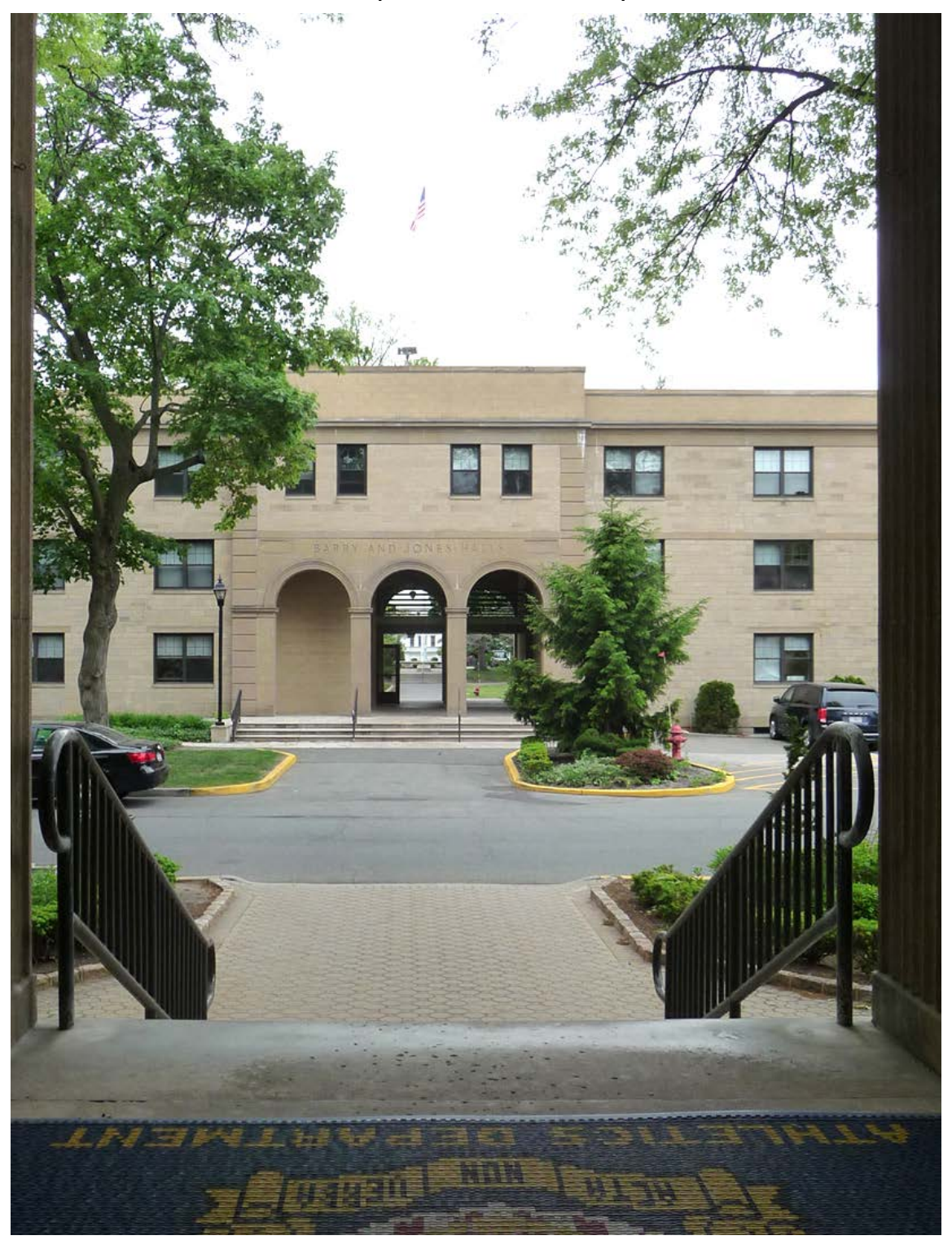


Figure 113. View of front of Wiley Hall from Amphitrite Pool, 1942 (USMMA Bland Library). Note that the flagpole was moved in 1943 from here to its present location.

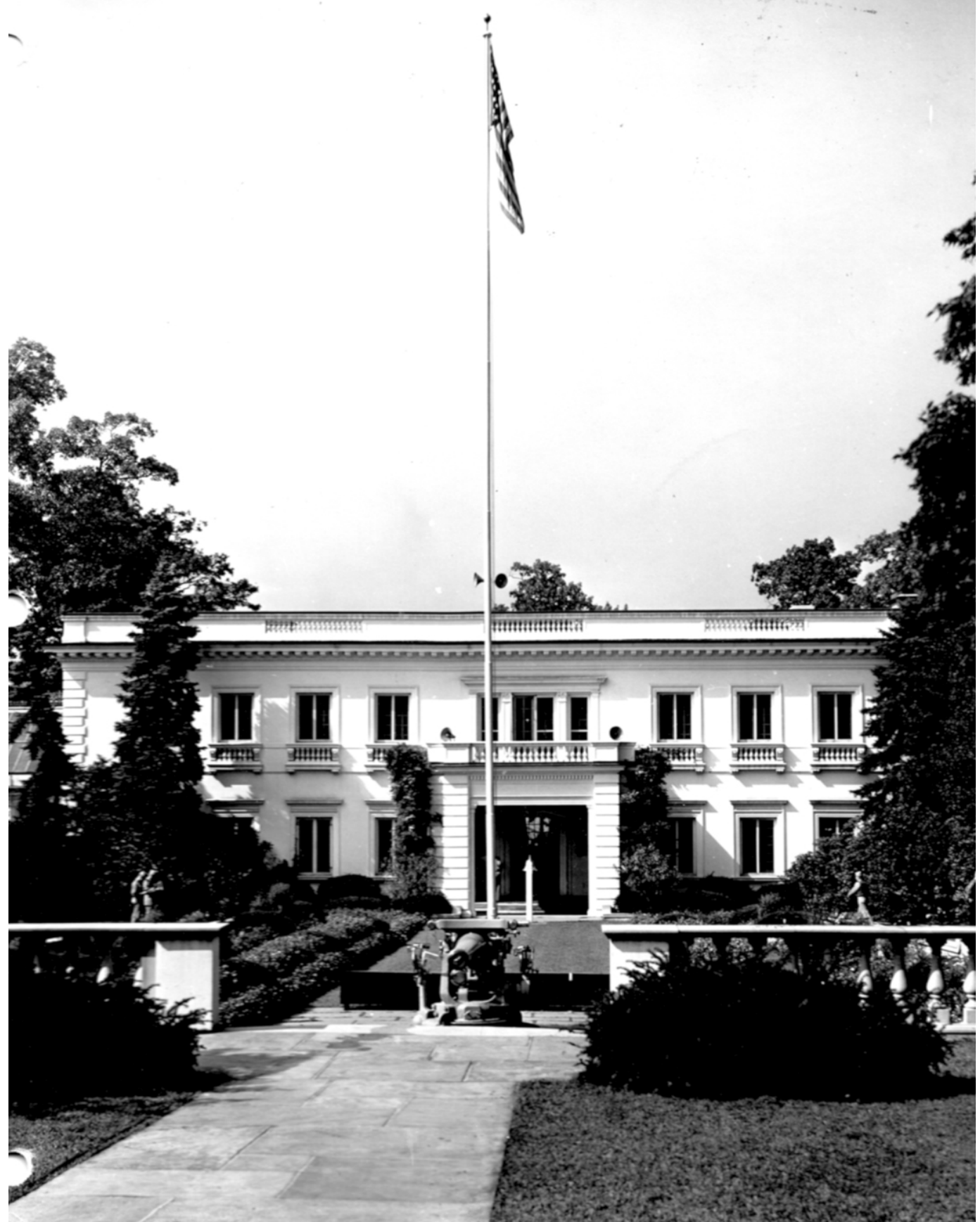


Figure 114. View of Wiley Hall from flagpole (ERDC-CERL, 2015).

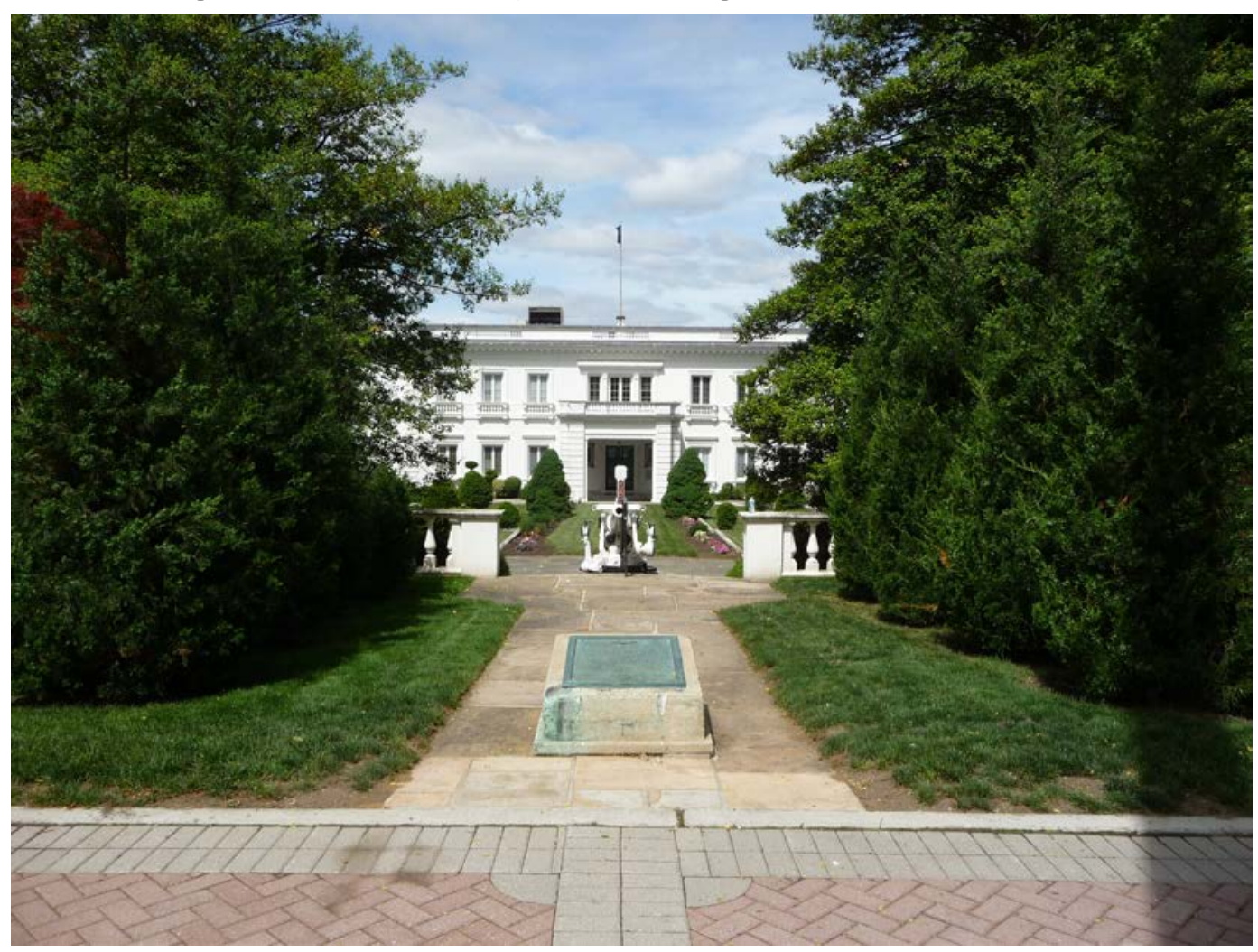

\subsubsection{Views from Library}

Axial views across the quadrangle from the library to the flagpole, Wiley Hall, and Delano Hall were an important part of the design of the Academy (Figure 115-Figure 118). 
Figure 115. View from library toward quadrangle, 1967 (USMMA Bland Library).

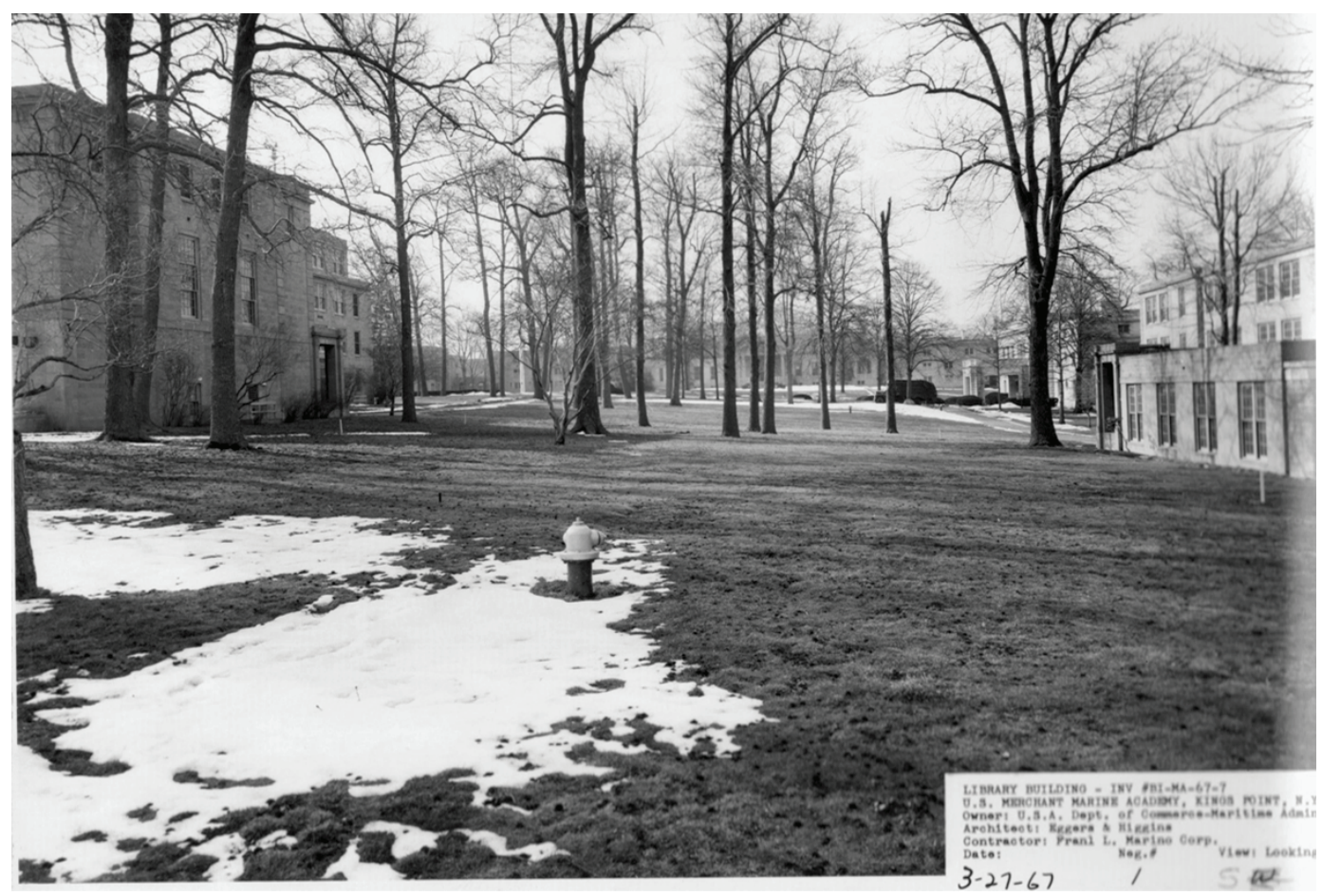

Figure 116. View from library to quadrangle (ERDC-CERL, 2015).

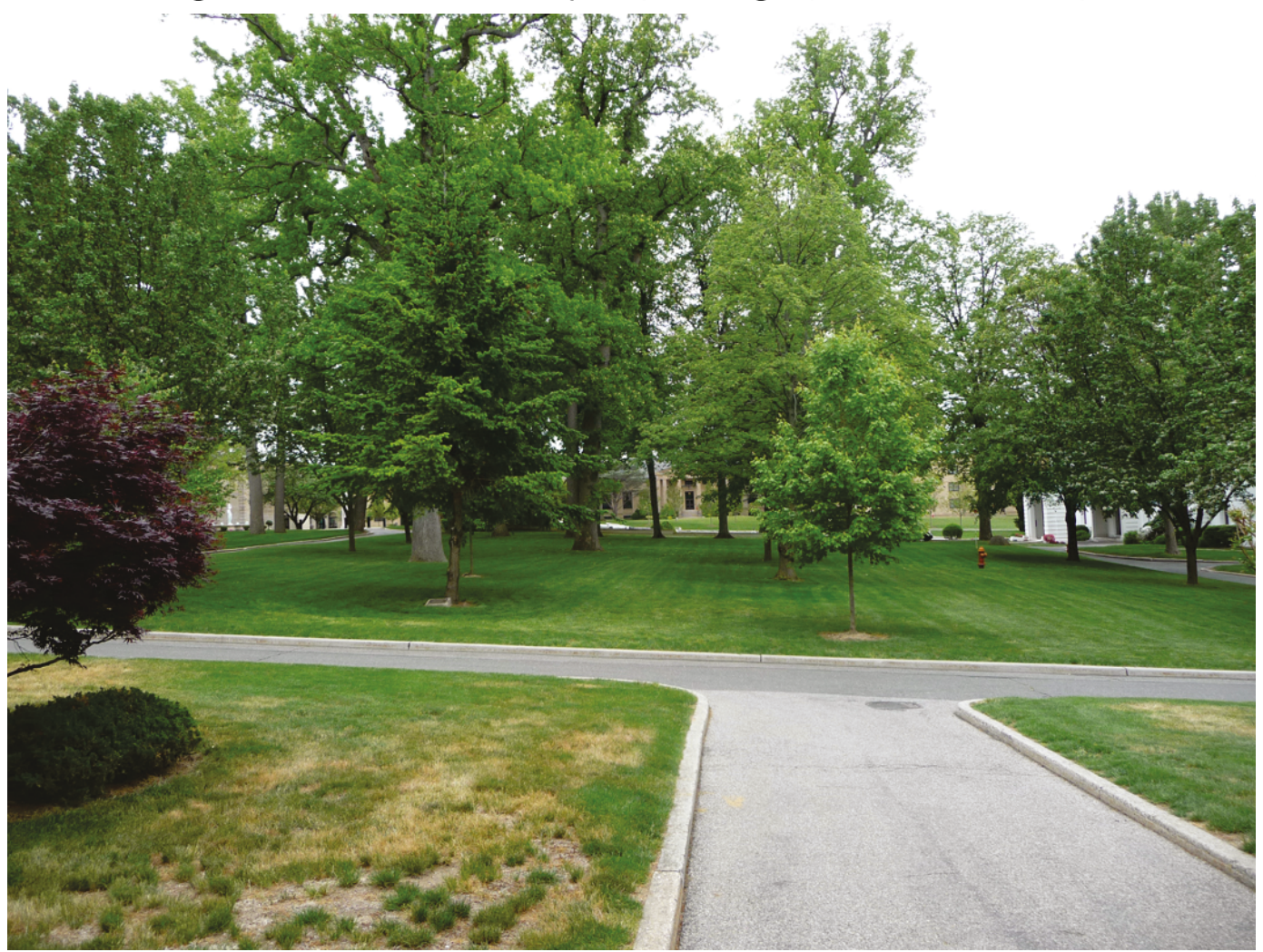


Figure 117. View of Delano Hall from quadrangle, 1940s (USMMA Bland Library).

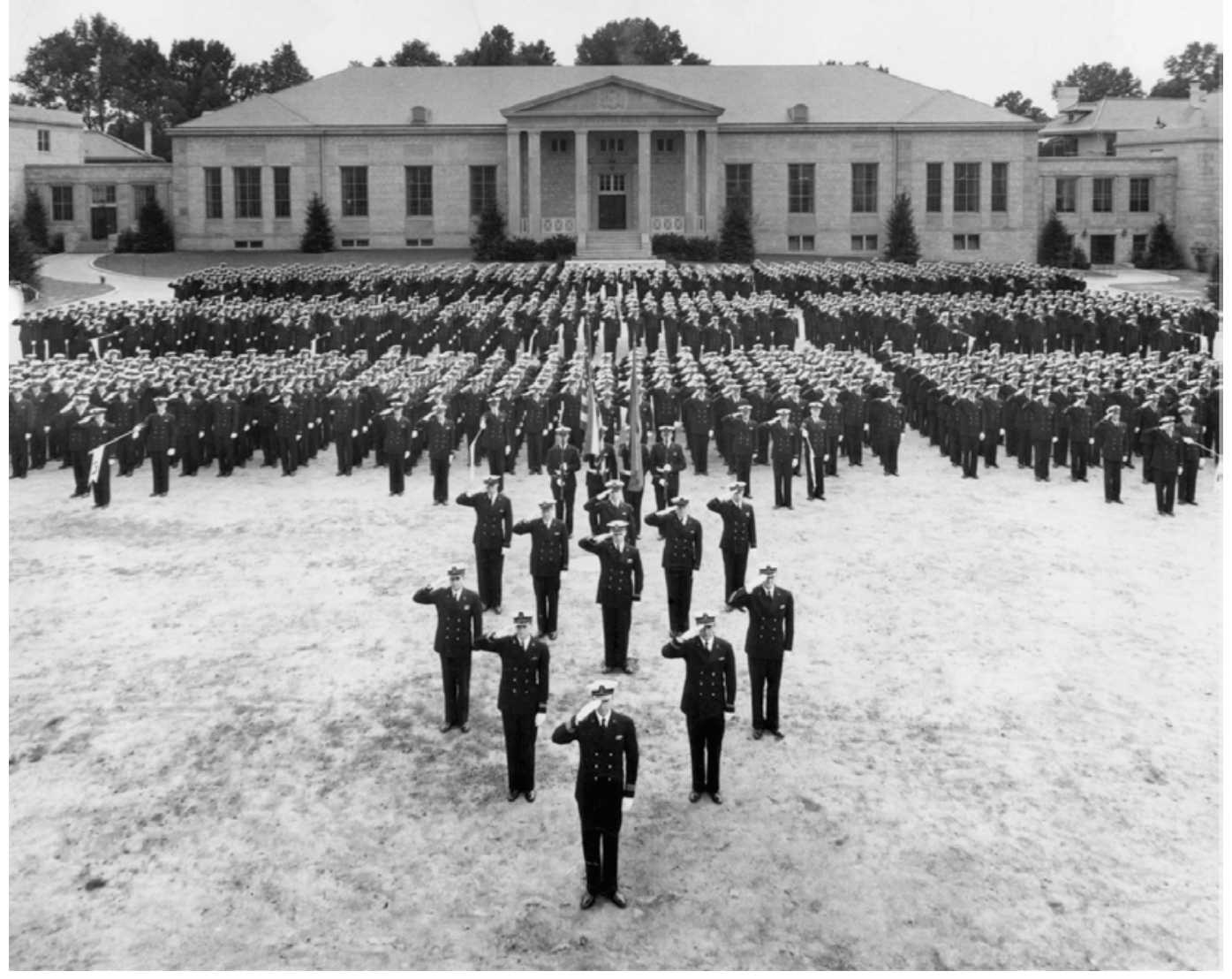

Figure 118. View of Barney Square and Delano Hall (ERDC-CERL, 2015).

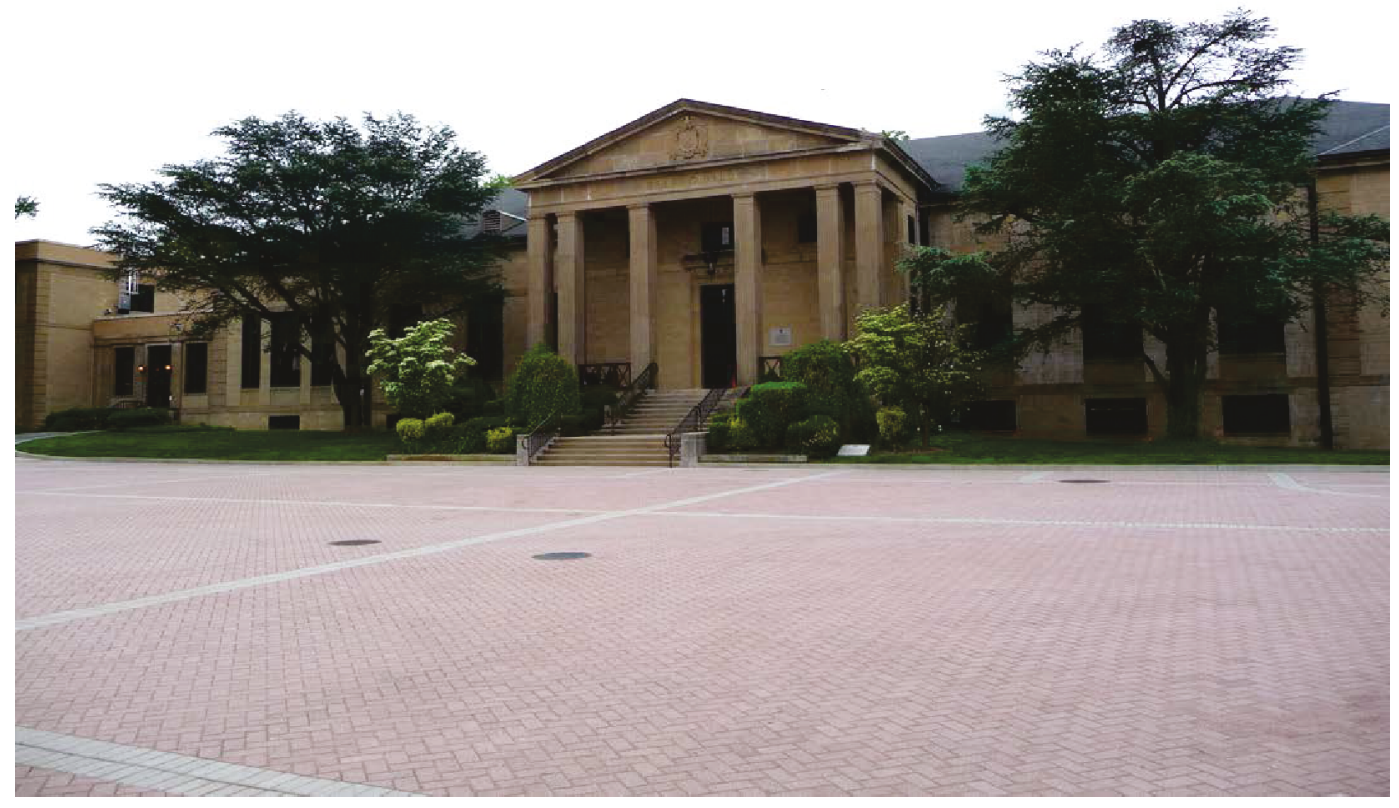




\subsubsection{Views from Delano Hall}

Axial views across the quadrangle from Delano Hall to the flagpole, Wiley Hall, and the library were an important part of the Academy's design (Figure 119-Figure 120).

Figure 119. View toward quadrangle from Delano Hall, 1947 (USMMA Bland Library).

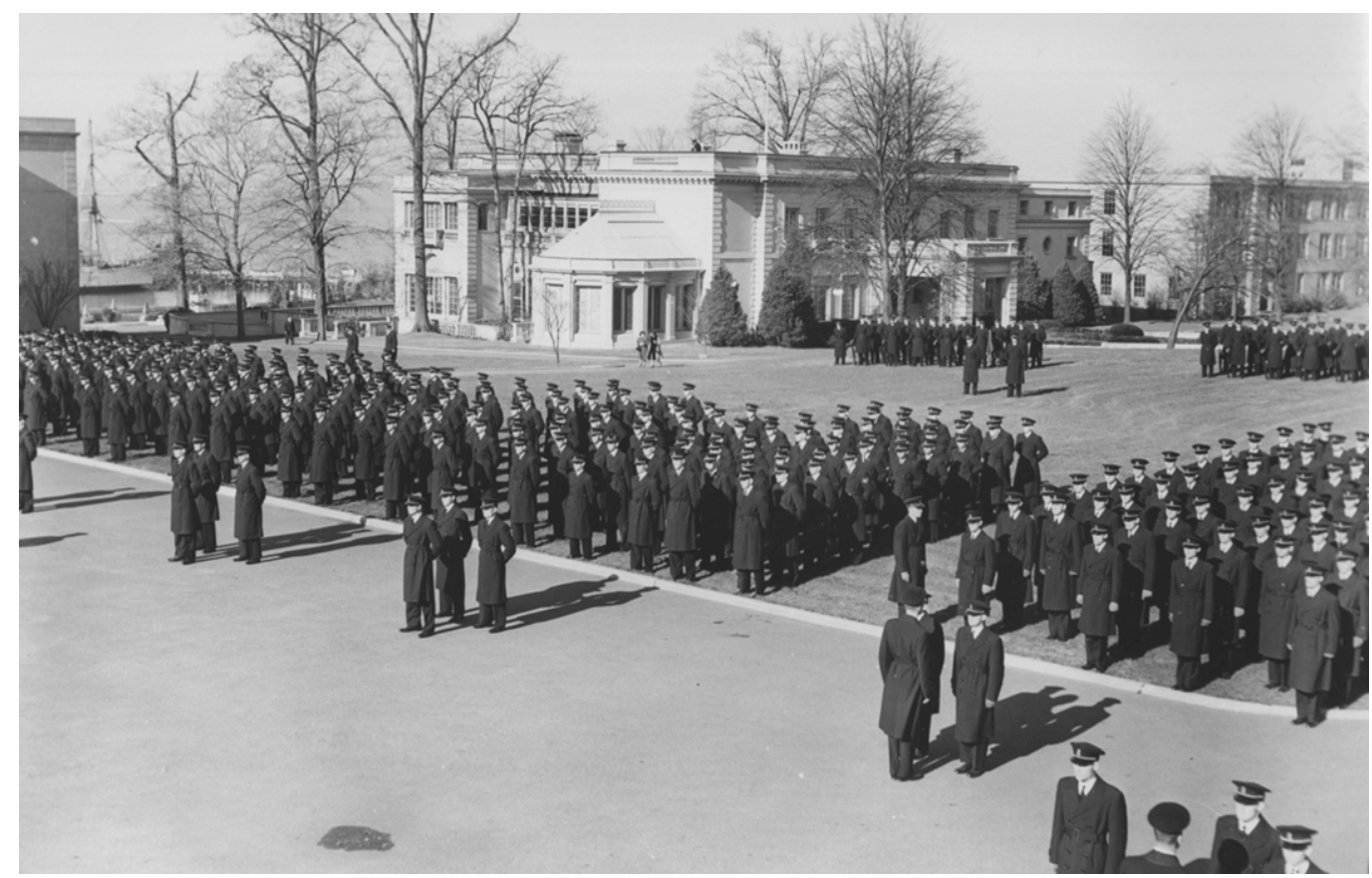

Figure 120. View from Delano Hall toward quadrangle (ERDC-CERL, 2015).

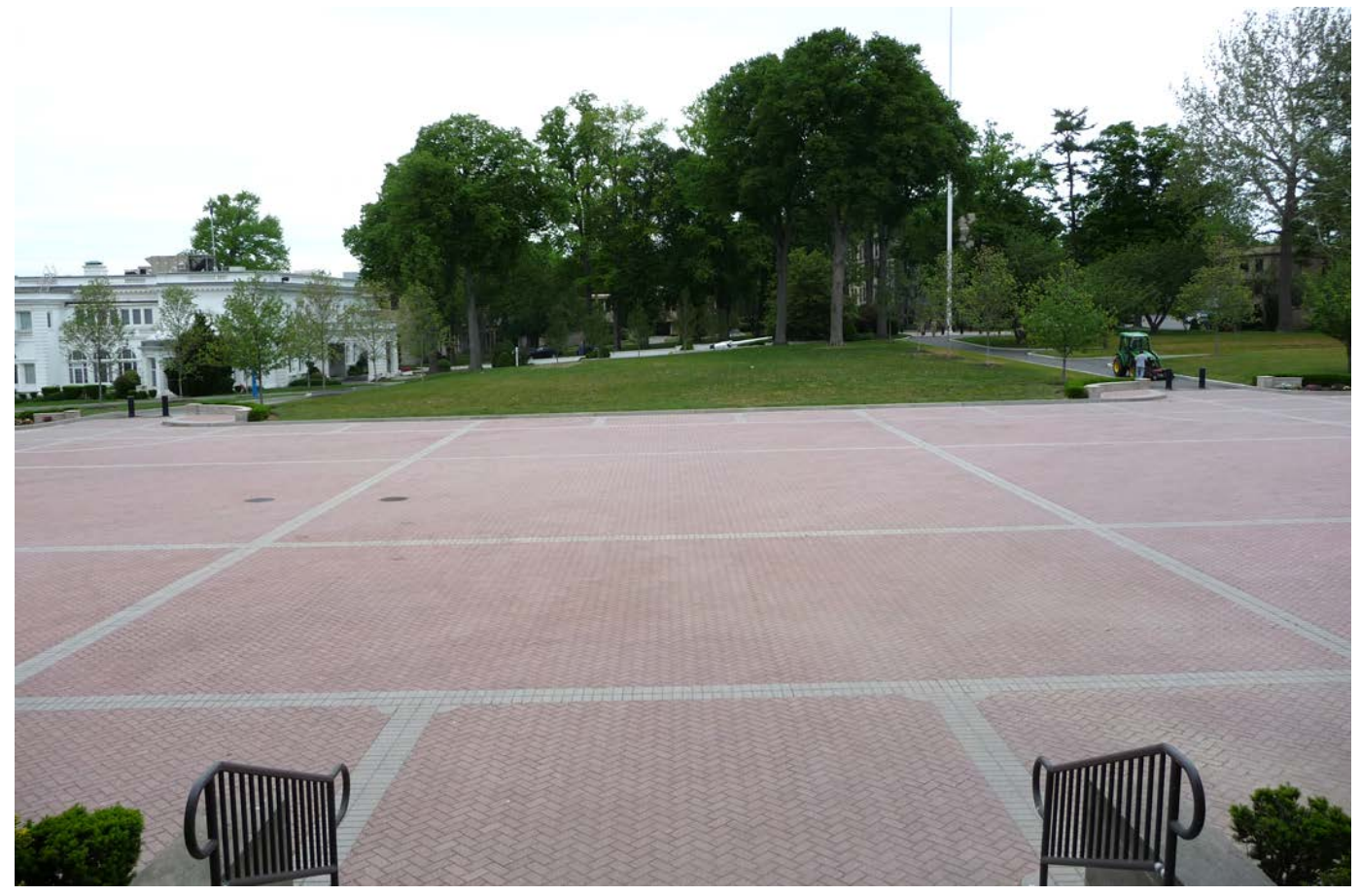




\subsubsection{Views along Steamboat Road}

Although no historic images were found for the views along Steamboat Road, this road has the historical significance of being both the road to the steamboat pier and public beach and the formal entrance to the Academy (Figure 121-Figure 125).

Figure 121. Vickery Gate is the formal entrance to the Academy, and it is located along Steamboat Road (ERDC-CERL, 2015).

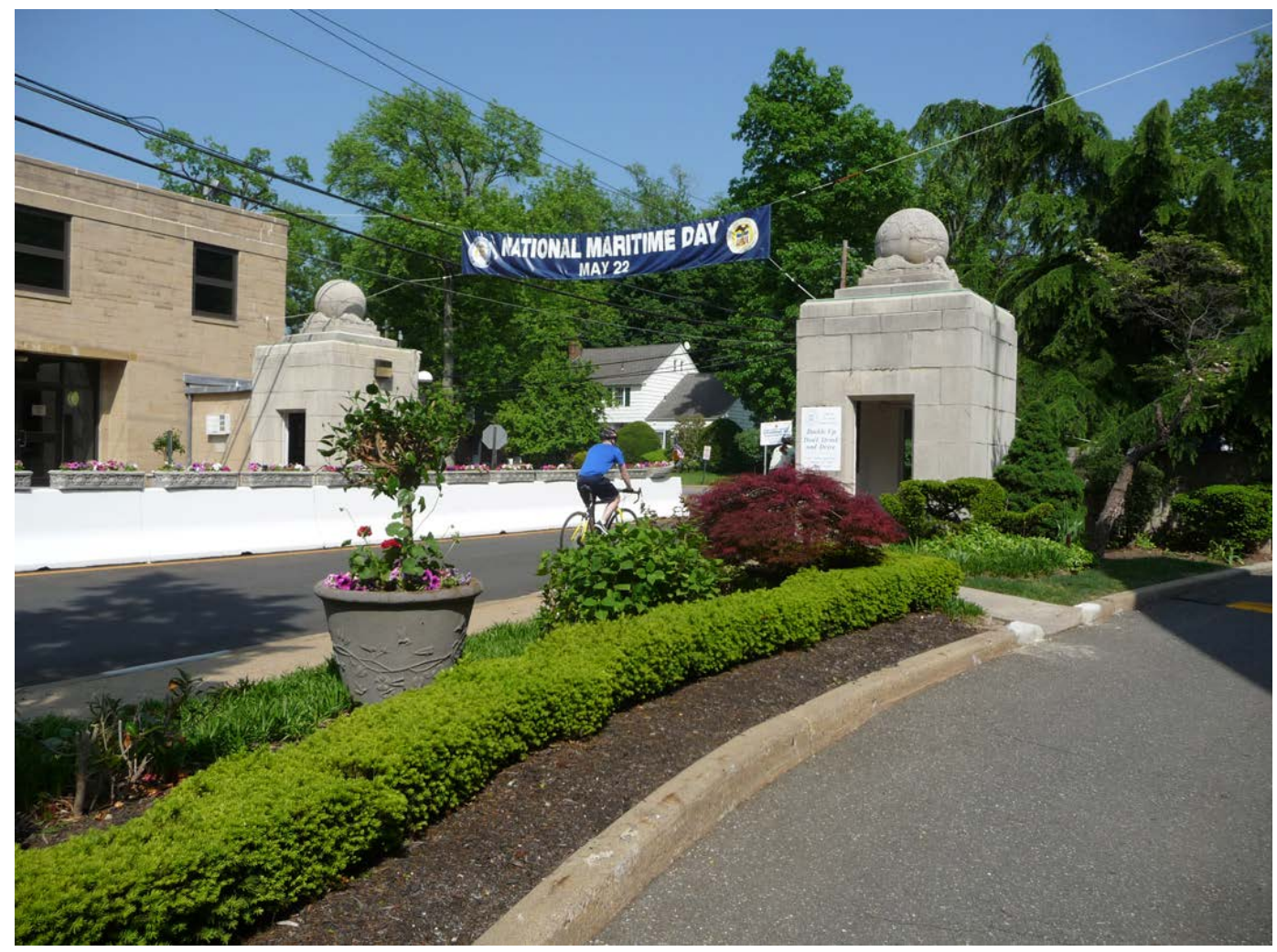


Figure 122. Entrance to Academy along Steamboat Road is just inside Vickery Gate (ERDC-CERL, 2015).

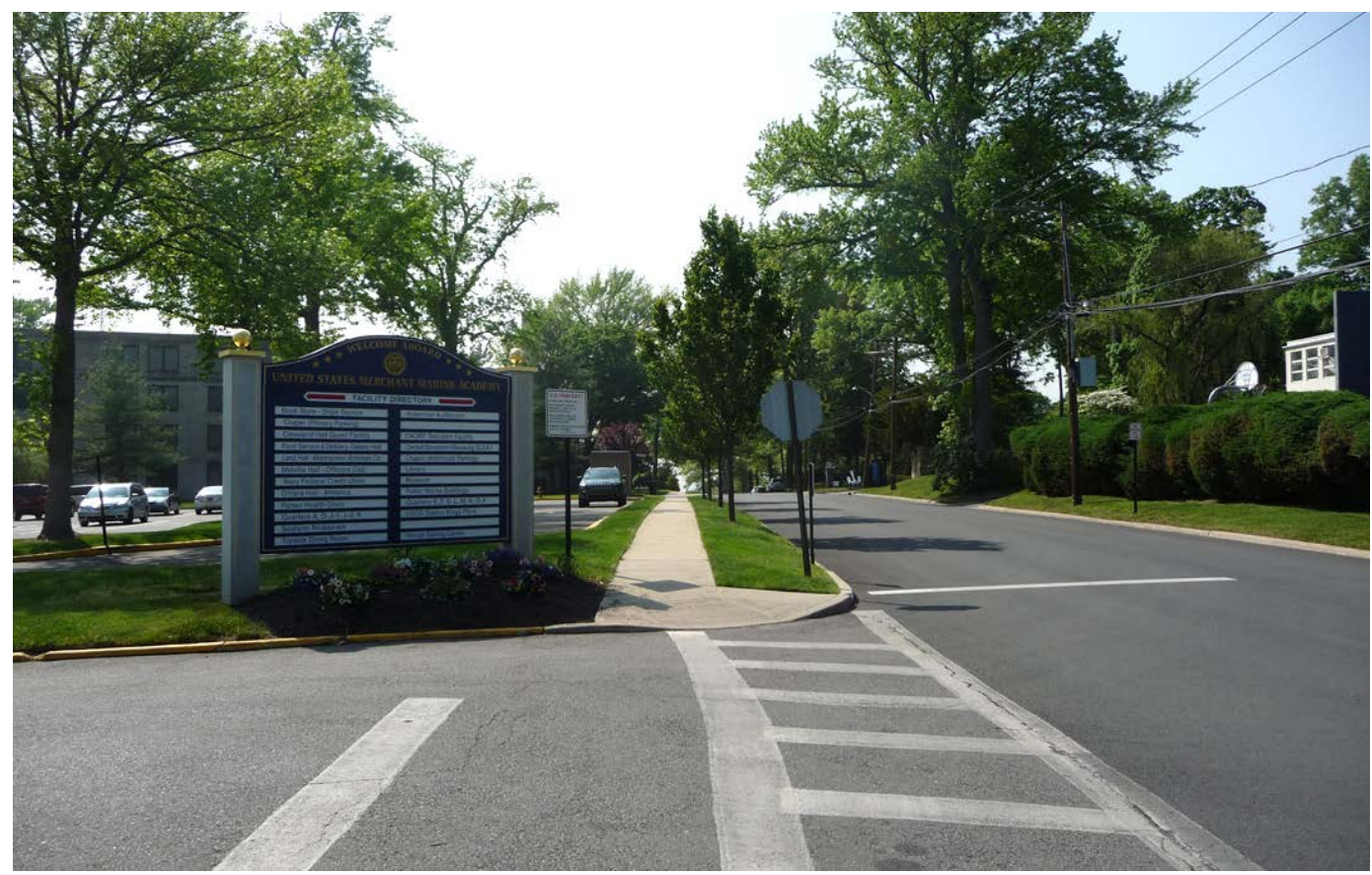

Figure 123. View to water from Steamboat Road (ERDC-CERL, 2015).

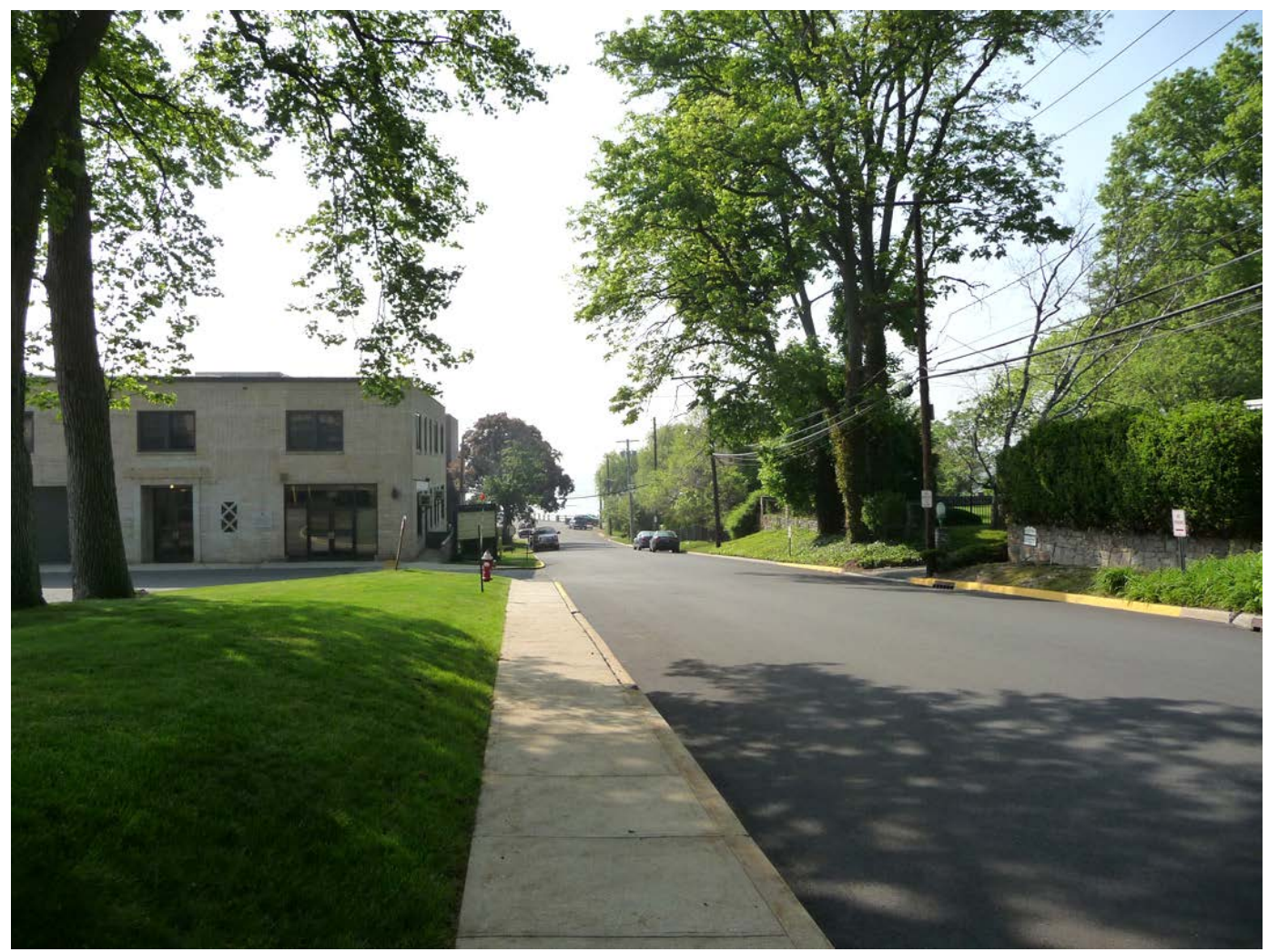


Figure 124. View toward Vickery Gate from Steamboat Road (ERDC-CERL, 2015).

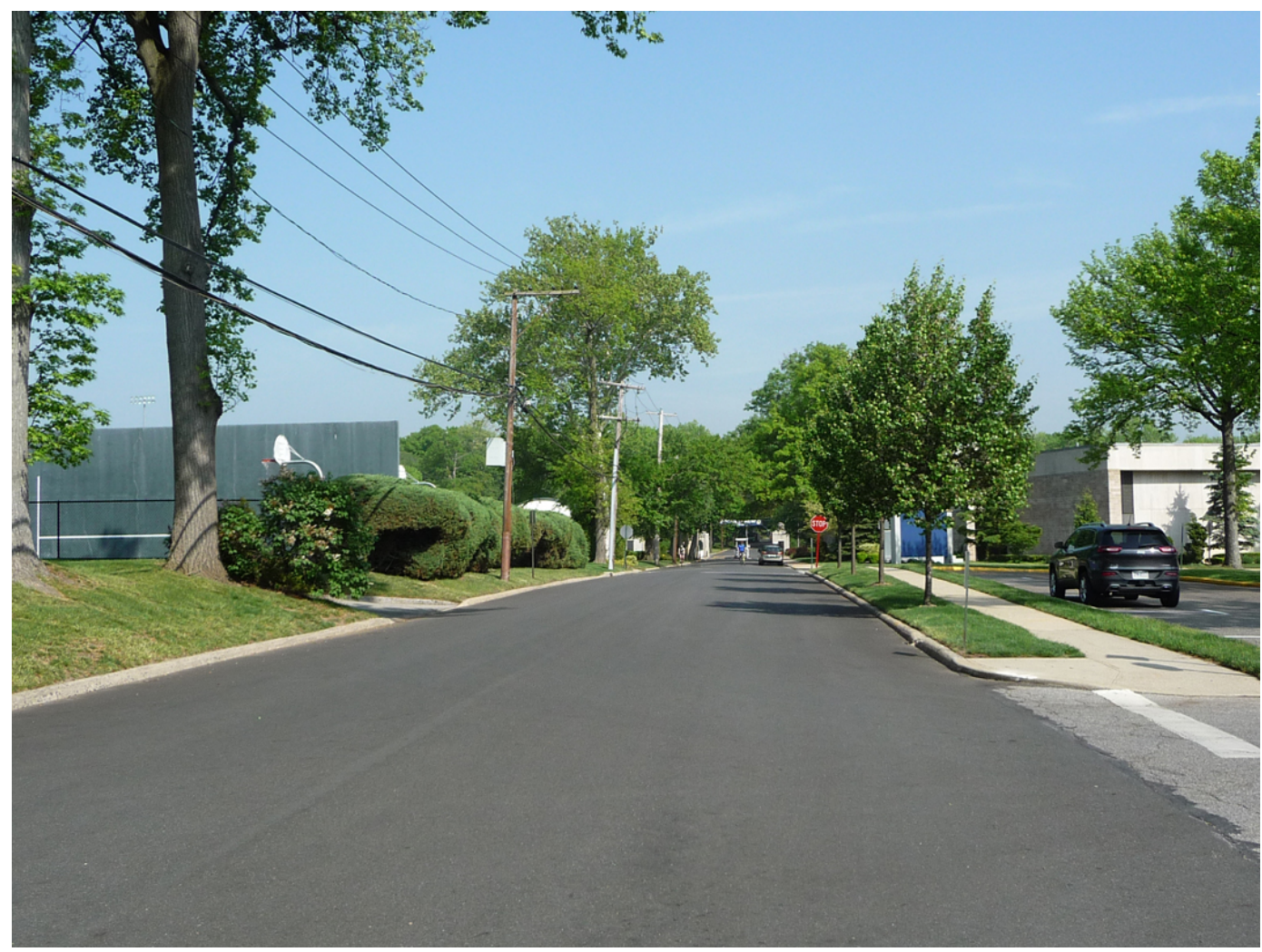

Figure 125. View along Steamboat Road near American Merchant Marine Museum (ERDC-CERL, 2015).

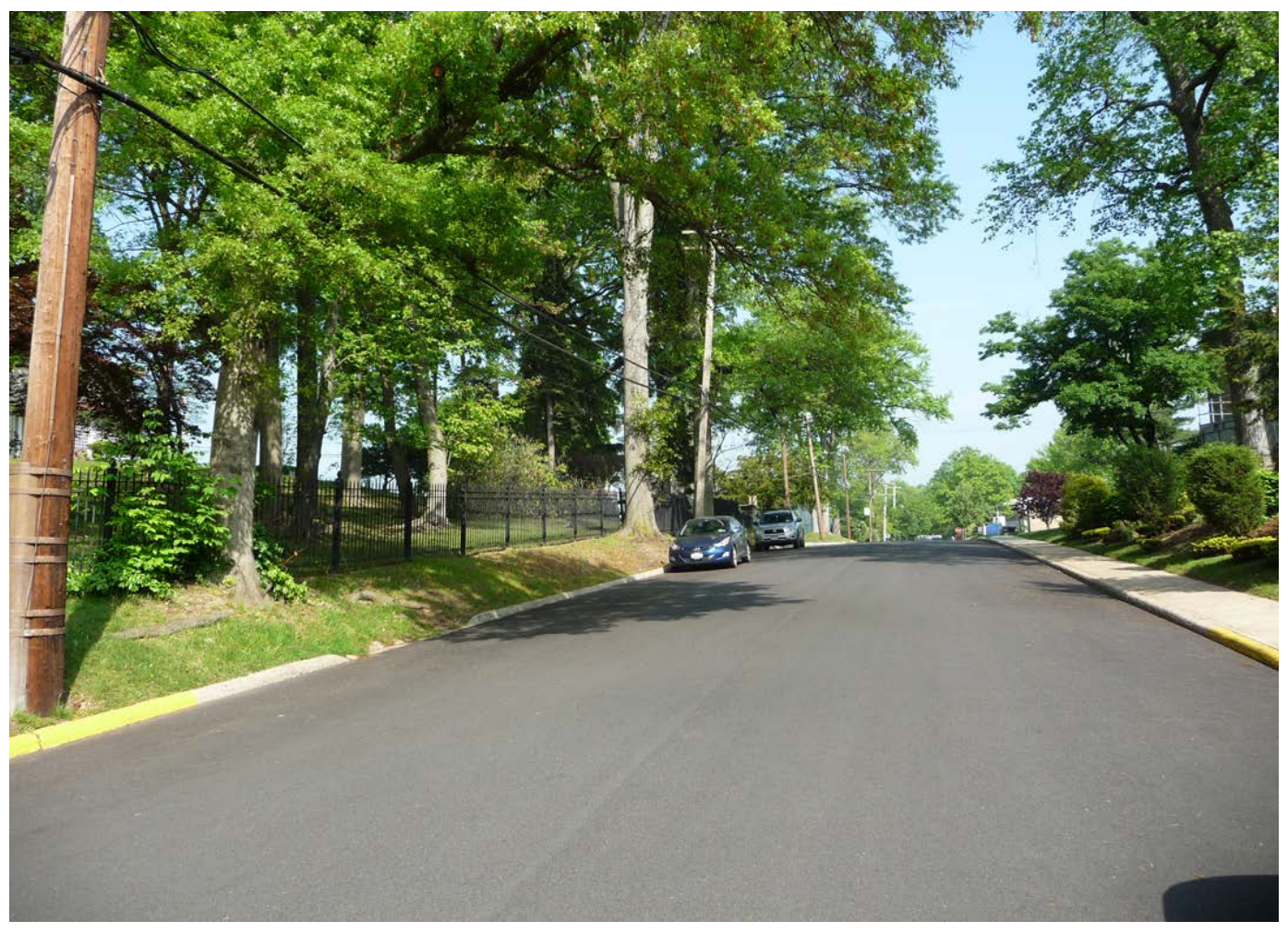


(Intentionally blank.) 


\section{Recommended Landscape Management Practices}

\subsection{Preserving historic character and character-defining features}

\subsubsection{Preservation zone use}

The use of preservation zones establishes a framework for planning for the operation, maintenance, and rehabilitation of a large site where there are varying degrees of original design, use, public access, and integrity. The concept of zoning, while establishing a logical framework, is also consistent with the techniques of original architectural programming, design, and construction.

The zoning of the landscape identifies the differences between more significant and less significant areas and assigns a numerical rating, or level, to each zone. The zone ratings establish management and treatment requirements for each zone (i.e., highly significant public spaces may be in a "preservation zone" where maintenance is tightly controlled, replacements are restricted, and new construction or features are discouraged). At the other end of the spectrum, areas with less integrity may be subject to normal maintenance and open to a much broader range of modifications. The treatment guidelines for each level convey the general principles of preservation applied within the zone.

\subsubsection{Preservation zones at USMMA}

\subsubsection{Level 1 (red)}

Level 1 areas are those that exhibit unique or distinctive qualities, original materials or elements, or representative examples of skilled craftsmanship, and areas of greater historical integrity. Level 1 areas may be distinguished from Level 2 areas by concentrations of detailing or richness of finish material and detail.

Guideline-The character and qualities of this zone should be maintained and preserved as the highest priority. 


\subsubsection{Level 2 (yellow)}

Level 2 areas are those that exhibit distinguishing qualities or original materials and/or features, or that represent examples of skilled craftsmanship. Level 2 areas generally are those with a lower density of original materials and detailing than the primary spaces rated as Level 1.

Guideline-Every effort should be made to maintain and preserve the character qualities of this zone.

\subsubsection{Level 3 (green)}

Level 3 areas exhibit distinguishing qualities or original materials and/or features, or represent examples of skilled craftsmanship. Level 3 areas generally have a lower density of original materials and detailing than the primary spaces rated as Level 1.

Guideline-While these historic areas have low integrity, consideration should be taken during undertakings to make better choices in the future. For example, if modern site furnishings need to be replaced, they can be replaced with ones that match the rest of the Historic District and provide visual continuity and consistency between zones.

\subsubsection{Level 4 (blue)}

Level 4 areas are outside the Historic District and have little or no historic features remaining. These areas may include new construction or new land uses.

Guideline-While these areas are where new construction and modifications have little or no impact, care needs to be taken if undertakings are within the Historic District's viewshed. Consultation may be required if this is the case.

Figure 126 is a map of USMMA showing the landscape preservation zones. 
Figure 126. Map of USMMA showing landscape preservation zones for treatment recommendations (ERDC-CERL).

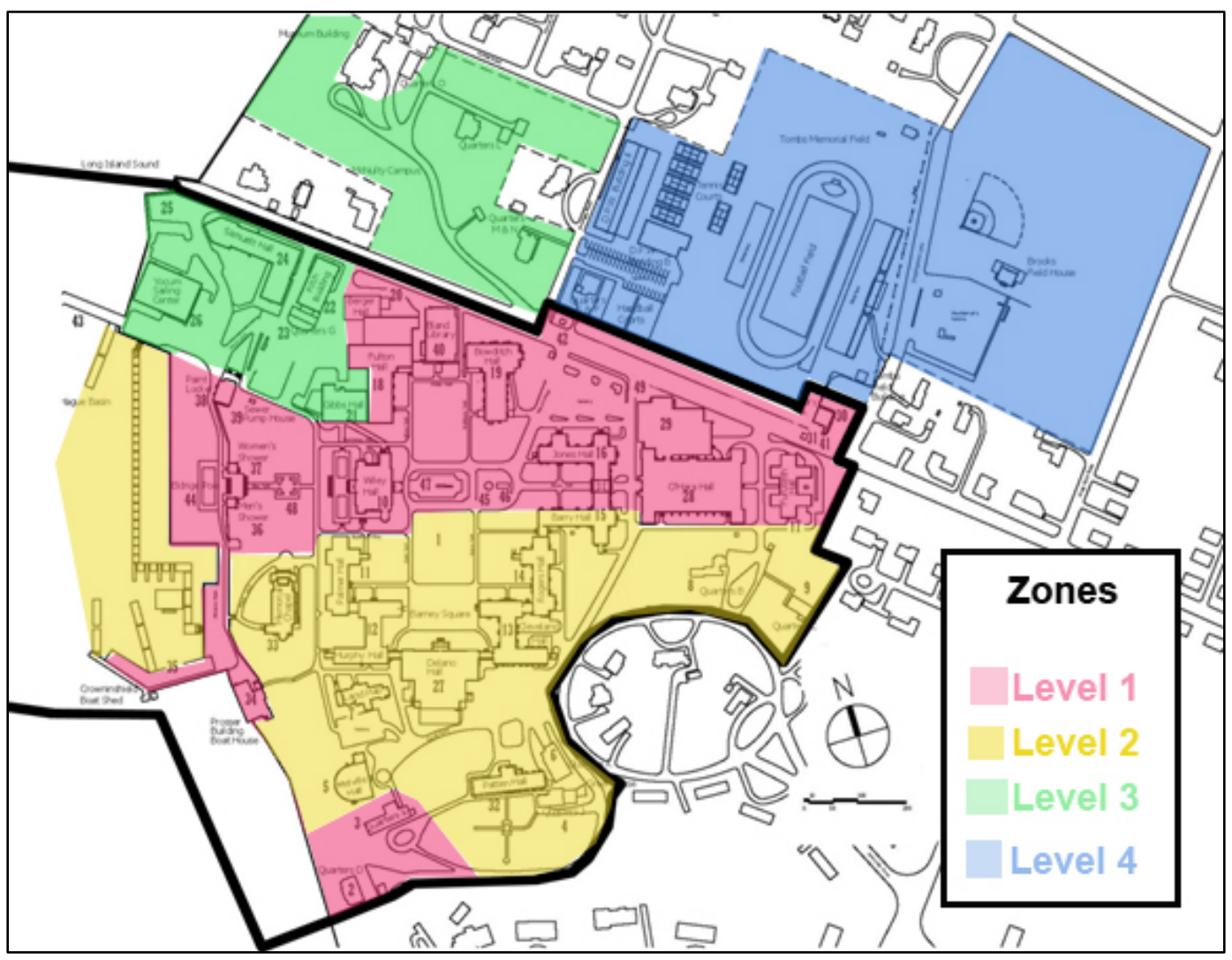

\subsubsection{Circulation patterns}

The circulation patterns of the Chrysler estate were preserved during the design of the Academy's roadways and walkways. The granite curbs adjacent to Wiley Hall are contributing features, and they should be preserved and repaired, or replaced in kind when needed. The roadways and sidewalks are part of the design and layout of the Academy. They are character-defining features of the landscape and should be preserved.

\subsubsection{In-kind replacement}

Any repair or replacement of street, parking lot, driveway, sidewalk, curb, and gutter and storm drainage structures should be done with in-kind materials. Changes to historic circulation patterns and materials in the Historic District may be an adverse effect, and SHPO consultation should occur.

Zone 1 and Zone 2. In-kind replacement or repair of historic circulation material is recommended. No new materials should be added. Roadways 
and sidewalks should be in historic locations. No new circulation is recommended. If new circulation is required, however, it will require consultation with the SHPO.

Zone 3 and Zone 4. While consultation and material consistency may not be necessary, compatible materials to those in the Historic District are ideal so there is visible continuity throughout the Academy's landscape. Selection on one or two types of material to be used throughout the Academy is recommended. For example, if sidewalks throughout the Historic District are historically made of concrete, the addition of brick pavers does not allow for uniformity and visual continuity.

\subsection{Vegetation}

\subsubsection{Historic character}

The design and layout of the Academy carefully preserved the layout and vegetation of the Chrysler estate. For example the grove of mature shade trees between Wiley Hall, Bland Library, Fulton Hall, and Bowditch Hall is visible in Chrysler-era photographs. While several trees have been lost in storms, the grove still provides character to the buildings and the landscape. While no Academy-era planting plans were found during the historical research for this project, documentation of simple foundation plantings for the Academy buildings is visible on the 1942 photographs (see Section 2.1.6). So while a historic plant list appears not to exist, the habitat, texture, and other vegetation-related information can be gleaned from the photographs.

\subsubsection{In-kind replacement}

When vegetation is lost in a historic landscape due to old age, storms, disease, or pests, the tree or shrub should be replaced in kind unless the historic species has known pest or disease problems, or if the location of the vegetation is affecting the historic fabric of the buildings. In those cases, a suitable vegetation substitution or alternate location should be found; for example, replace historic landscape with a species without pest or disease problems, but choose one with similar habit, size, texture, and characteristics to the historic one it is replacing. 
Not replacing the missing vegetation in the Historic District may be considered an adverse effect, and SHPO consultation should occur in that case.

Zone 1 and Zone 2. In-kind replacement or repair of historic trees is required unless pest and disease problems necessitate the selection of a compatible replacement species. Trees, shrubs, and flower beds should be in historic locations. No new flower beds are recommended, unless they are placed in prior bed locations as found in historic photographs. If new vegetation is desired, the plan may require consultation with SHPO. Selection of shrubs, perennials, and groundcovers should be from the plant list in Appendix A, or the selection should match historically appropriate material in the Historic District.

Zone 3 and Zone 4. Selection of vegetation to be planted in these zones should be from Appendix A. While new beds and shrubs may be added in these zones, care must be taken to make the best water conservation choices as well and avoid any invasive species.

\subsubsection{Sustainability}

President Obama signed Executive Order (EO) 13514, "Federal Leadership in Environmental, Energy and Economic Performance" on 5 October 2009. This EO states that it is "the policy of the United States that Federal agencies shall increase energy efficiency; measure, report, and reduce their greenhouse gas emissions from direct and indirect activities; conserve and protect water resources through efficiency, reuse, and stormwater management; eliminate waste, recycle, and prevent pollution; [and] strengthen the vitality and livability of the communities in which Federal facilities are located."

It has been recommended that federal facilities develop and maintain a sustainable landscape plan, which may encompass the following landscape elements: site selection and planning, soils, water, vegetation, materials selection, human health and well-being, existing/historic facilities and cultural landscapes, construction, and operations and management.

Because native plants are adapted to regional conditions and climate, they ultimately require fewer resources and maintenance. The use of native and appropriate non-native plants can enhance biodiversity, reduce pesticide use, conserve water, and reduce energy costs. In addition, native and 
appropriate non-native plants also support important pollinator species that are necessary for plant reproduction. A healthy vegetation cover will also inhibit the establishment of invasive plants.

\subsubsection{Invasive species}

An invasive species is defined as an organism outside its native region, as a result of either intentional or unintentional human activities. Invasive species can cause ecological and economic harm by outcompeting native species in such traits as reproduction, early and rapid development, adaptability, tolerance of a broad range of environmental conditions, and a lack of natural population controls.

Invasive species found on Long Island (as rated "very high" by the New York State Office of Invasive Species Coordination)² are listed below:

- Acer platanoides L. (Norway maple)

- Alliaria petiolate (garlic mustard)

- Aralia elata (Japanese angelica tree)

- Berberis thunbergii (Japanese barberry)

- Brachypodium sylvaticum (slender false brome)

- Celastrus orbiculatus (Oriental bittersweet)

- Cynanchum louiseae (black Swallow-wort)

- Cynanchum rossicum (pale Swallow-wort)

- Elaeagnus umbellate (Autumn olive)

- Euonymus alatus (winged euonymus)

- Fallopia japonica (Japanese knotweed)

- Hydrilla verticillata (water thyme)

- Hydrocharis morsus-ranae (frogbit)

- Lonicera japonica (Japanese honeysuckle)

- Lonicera maackii (Amur honeysuckle)

- Lonicera morrowii (morrow's honeysuckle)

- Ludwigia grandiflora (Uruguayan primrose willow)

- Ludwigia peploides (floating primrose willow)

- Lythrum salicaria (purple loosestrife)

- Microstegium vimineum (Japanese stilt grass)

- Myriophyllum heterophyllum Michx. (broadleaf water-milfoil)

- Myriophyllum spicatum (Eurasian water-milfoil)

\footnotetext{
2 New York invasive species information provided by Cornell University Cooperative Extension
} (http://nyis.info/index.php), accessed June 2017. 
- Persicaria perfoliata (mile a minute weed)

- Phragmites australis (common reed grass)

- Pueraria montana (kudzu)

- Ranunculus ficaria (lesser celandine)

- Rhamnus cathartica (common buck thorn)

- Robinia pseudoacacia (black locust)

- Rosa multiflora (multiflora rose)

- Rubus phoenicolasius (wineberry)

- Alix atrocinerea (gray florist's willow)

- Trapa natans (water chestnut)

Many of the invasive species found around Long Island were originally planted as ornamentals, but they have since spread unintentionally. It is recommended that these plants not be used in the landscape. In addition, removal of any existing invasive species would improve the ecological integrity of USMMA and its surroundings, as well as create opportunities for more beneficial native species to be planted in their place.

\subsubsection{Plant list}

A plant list has been generated and included in this report's Appendix A. This plant list can serve as a guide to choosing plant materials that incorporate sustainable strategies. As discussed above, these plants are adapted to regional conditions and climates, thereby requiring fewer resources and less maintenance.

The basic planting palette used throughout historic landscape designs include large trees, evergreens, small ornamental trees, and a wide range of shrubs and ornamental grasses. Often, historic vegetation selections were made based on popular species that were widely available throughout the United States. In keeping with the historic planting characteristics, Appendix A provides suggestions for appropriate species that mimic the aesthetics of historic plant selections. The list is intentionally limited as a technique to aid in the development of a consistent historic character.

\subsubsection{Planting plans}

During research for this project, no original planting plans were found for the Academy. As a result, it is nearly impossible to determine a landscape design intent for the Academy. Without design intent, it is difficult to come up with historically accurate planting plans. For example, it is hard to tell 
the design intent of the foundation plantings for the Academy buildings. In historic photographs and plans, small plantings are visible to accent the entrances and corners of the buildings (Figure 127, Figure 128, and Figure 129). This design concept is supported by the rendering completed by the architect, Alfred Hopkins and Associates. (Figure 130). In photographs taken right after the construction, a few select buildings have more elaborate plantings that almost form a continuous bed at foundations (Figure 131). Future plantings along the foundations of the Academy buildings should follow these concepts.

Figure 127. Plantings at building entrances and corners of Jones and Barry Halls, 1943 (USMMA Bland Library).

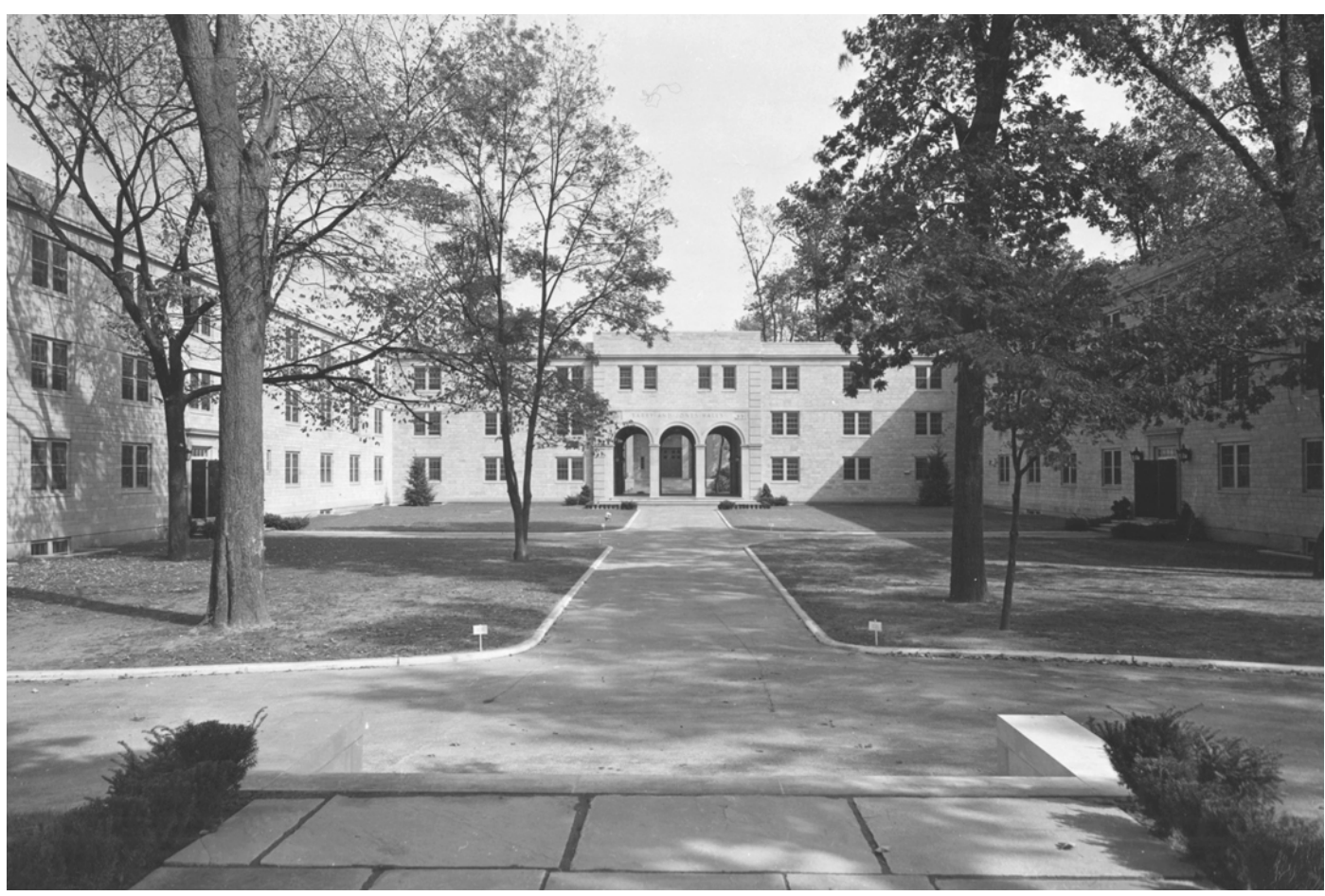


Figure 128. Foundation plantings in front of Delano Hall, 1943 (USMMA Bland Library).

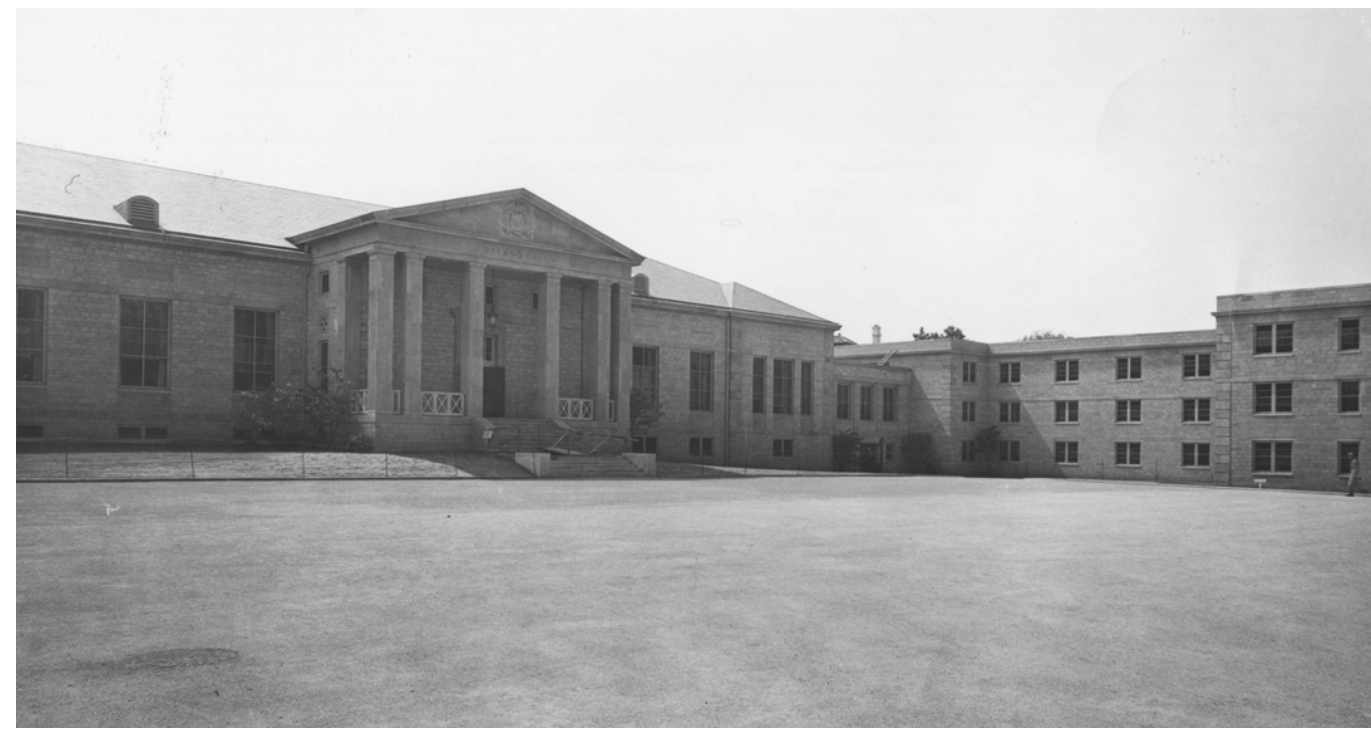

Figure 129. Preliminary design for Hospital Building showing plantings at entrances and corners, 1943 (USMMA).

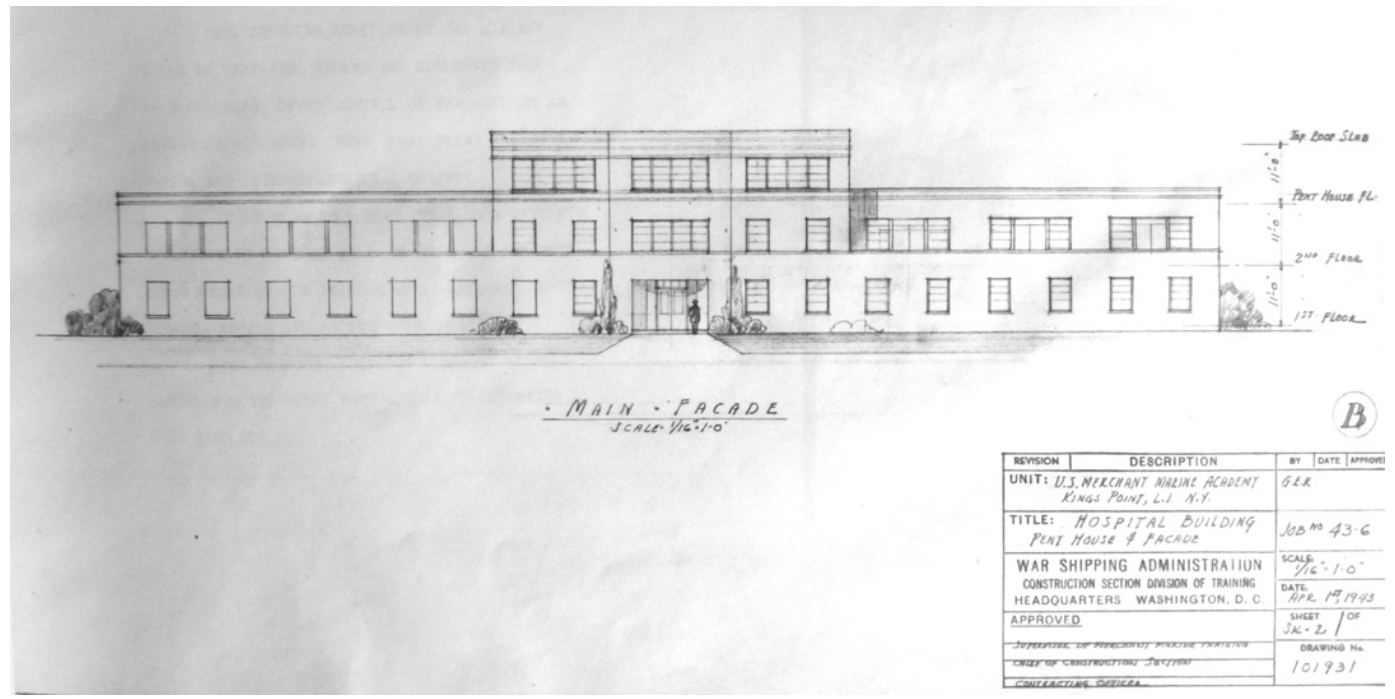


Figure 130. Academy rendering by Alfred Hopkins and Associates, undated (USMMA Bland Library).

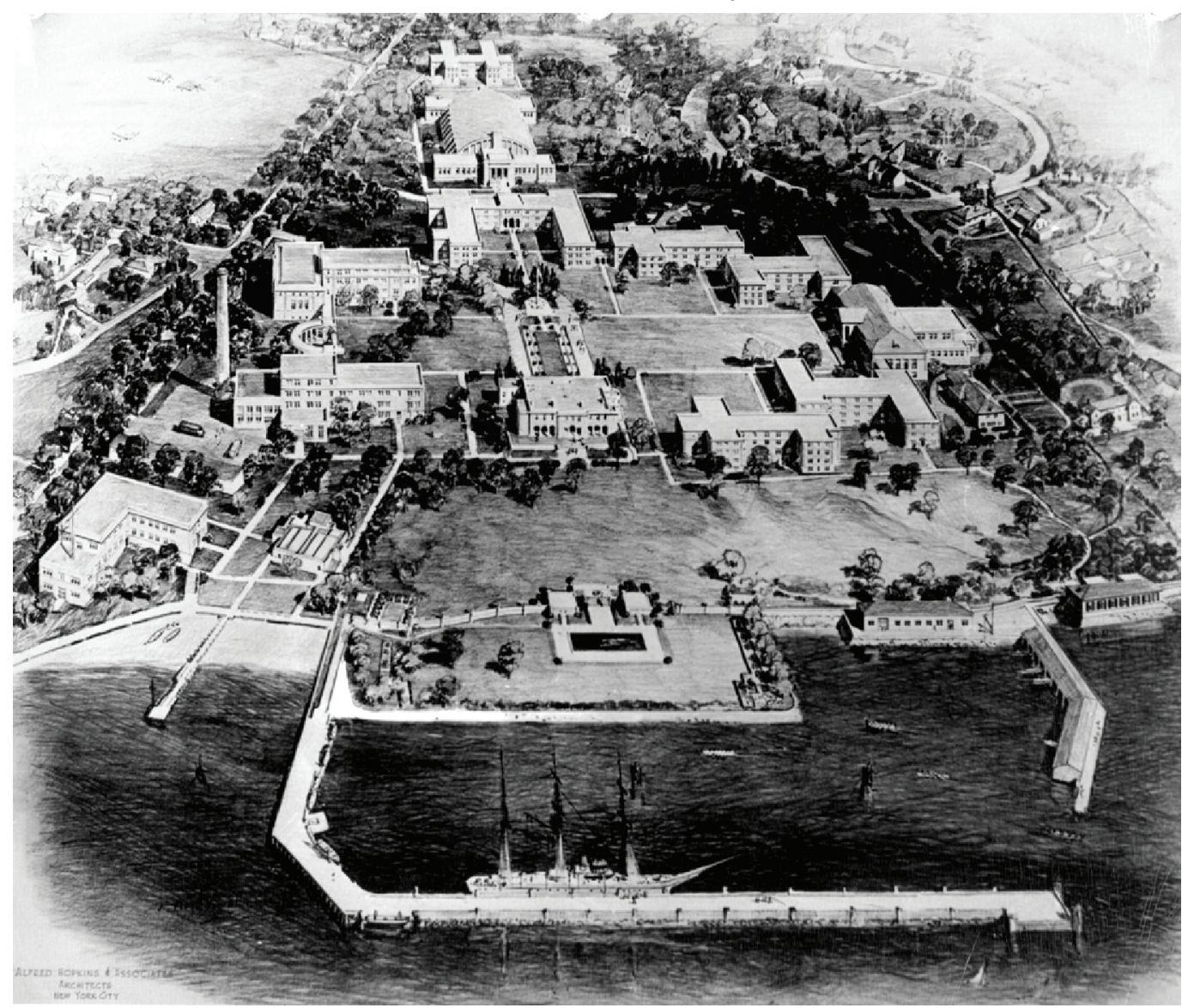

Figure 131. Foundation plantings in front of Fulton Hall, 1943

(USMMA Bland Library).

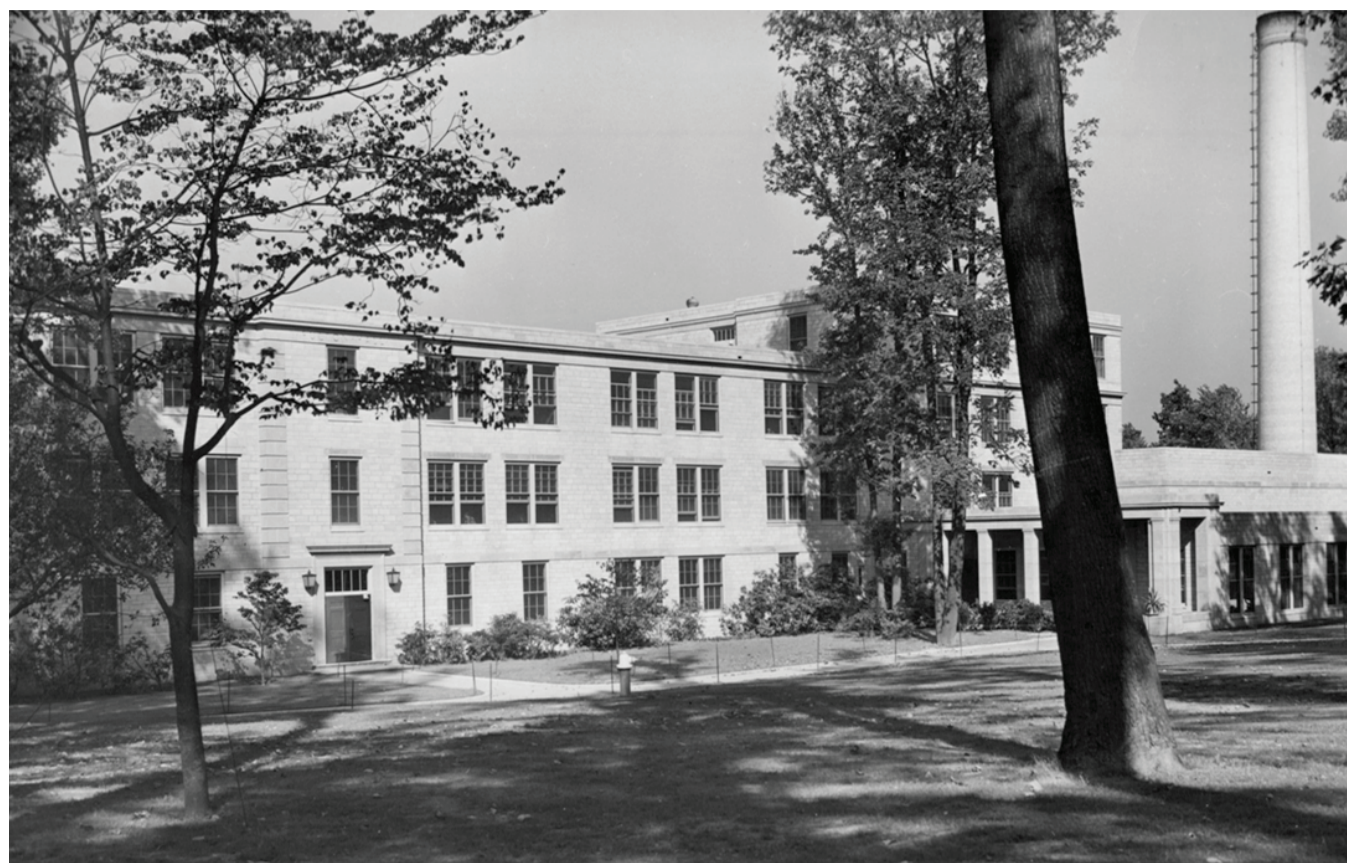


For the estates that pre-date the academy, there are many photographs and examples of planting designs from that era for many estates along the Gold Coast (Figure 132 and Figure 133). These estates were characterized with having lush foundation plantings, picturesque plantings surrounding the estates, and formal, geometric gardens that either were extended architecturally from the house or were sited either as a destination or as a visual feature in the landscape.

While these picturesque estate landscapes were removed to construct the Academy, the buildings and some of the circulation patterns remain.

Foundation plantings in the future for these estate buildings should have the character of the historic estates even though the surrounding grounds no longer exist.

Figure 132. Landscapes of Chrysler mansion (Wiley Hall), Houston Estate (demolished) and Schenck house (Land Hall), 1932 (USMMA Bland Library).

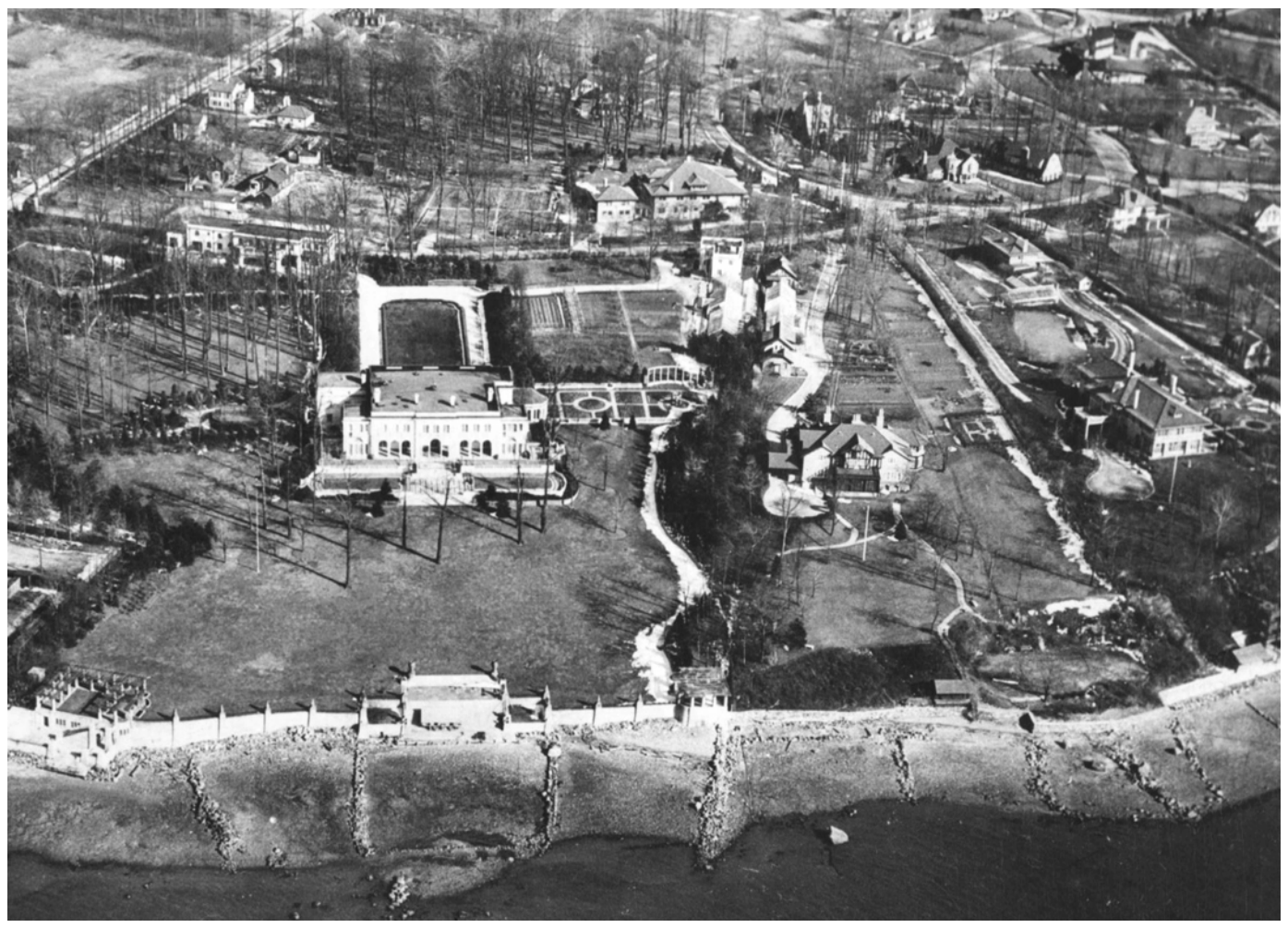


Figure 133. Photograph of foundation plantings around Schenck House (Land Hall), 1942 (USMMA Bland Library).

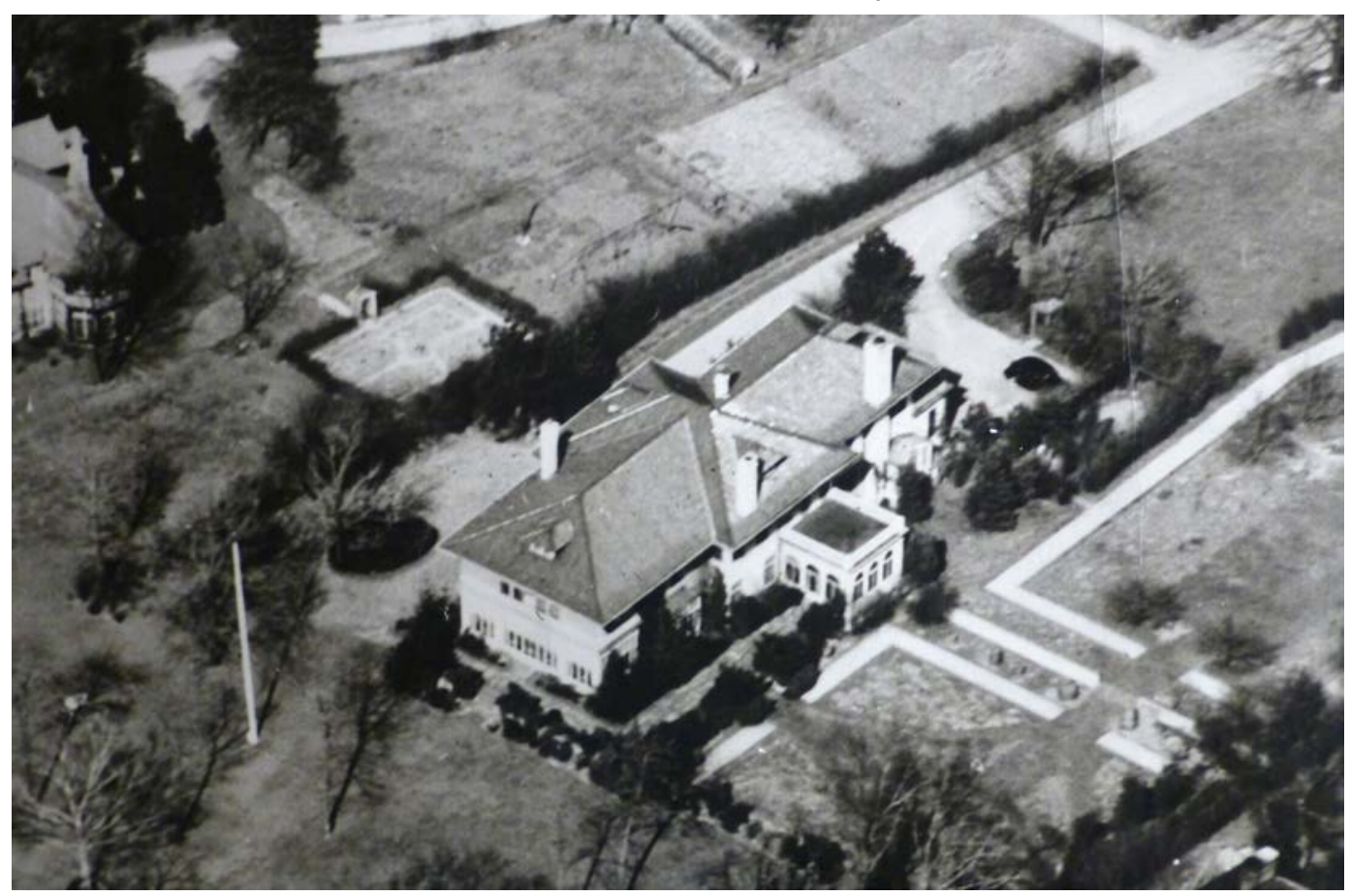

Three planting plans are provided below to facilitate plant selection and planting design that will emphasize the historic character of the historic district at USMMA (Figure 134, Figure 135, and Figure 136). The historic landscape characteristics were determined from photos and supplemented with planting concepts appropriate for the architectural style and period. 
Figure 134. Planting plan for the front of Wiley Hall and the flagpole area (ERDC-CERL, 2017.

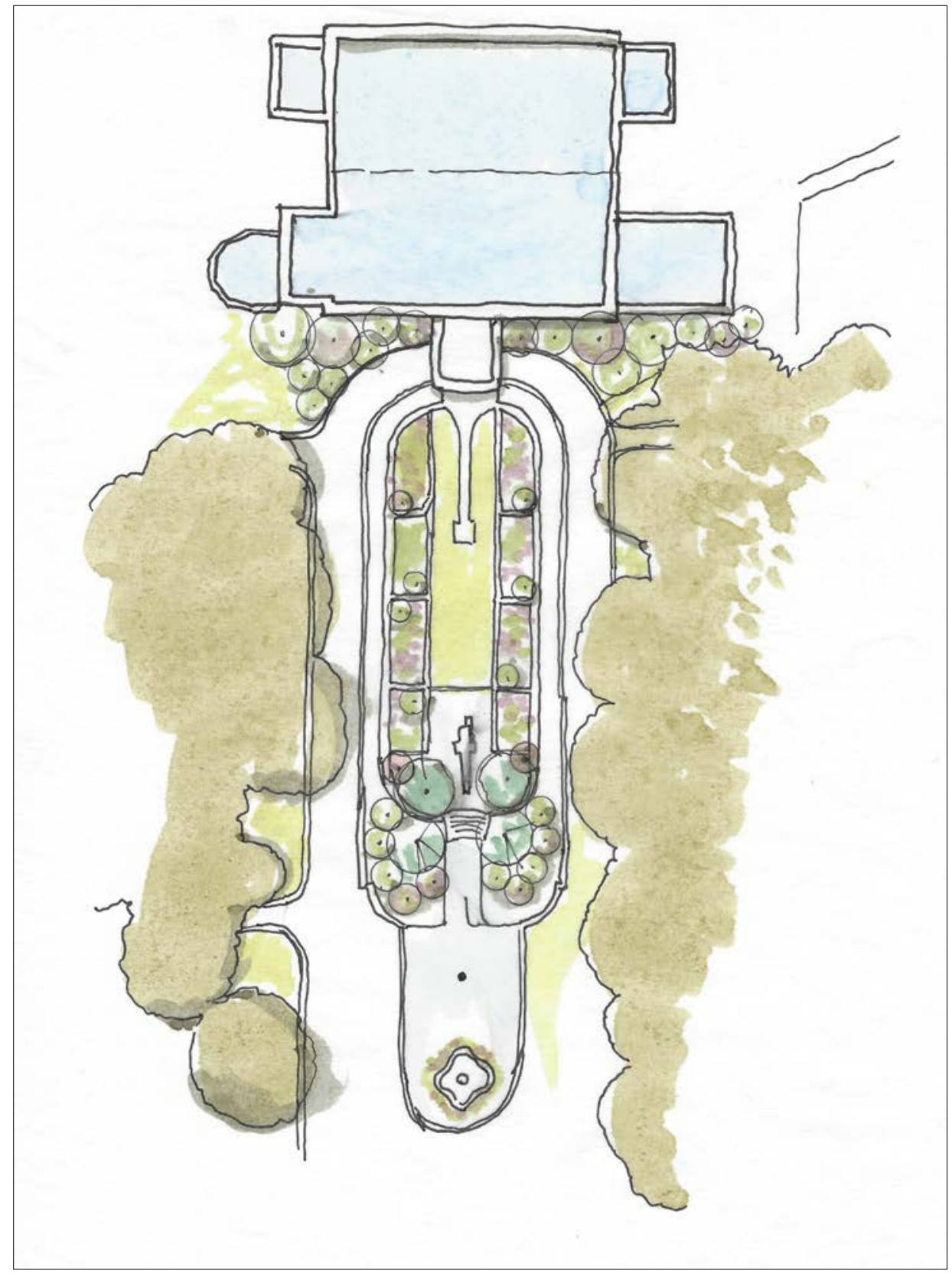


Figure 135. Planting plan for rear of Wiley Hall (ERDC-CERL 2017).

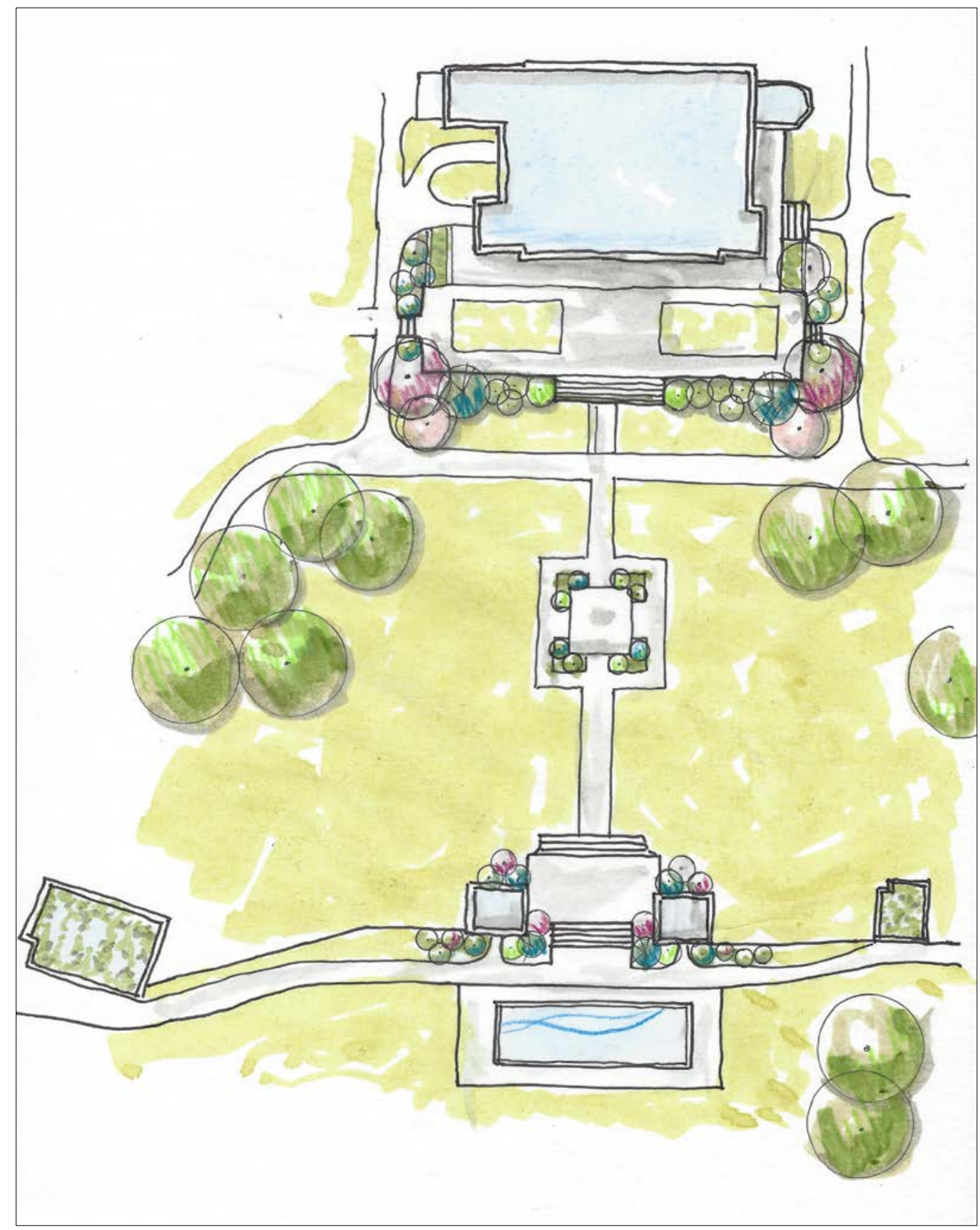


Figure 136. Planting plan for the front of Melville Hall (ERDC-CERL, 2017).

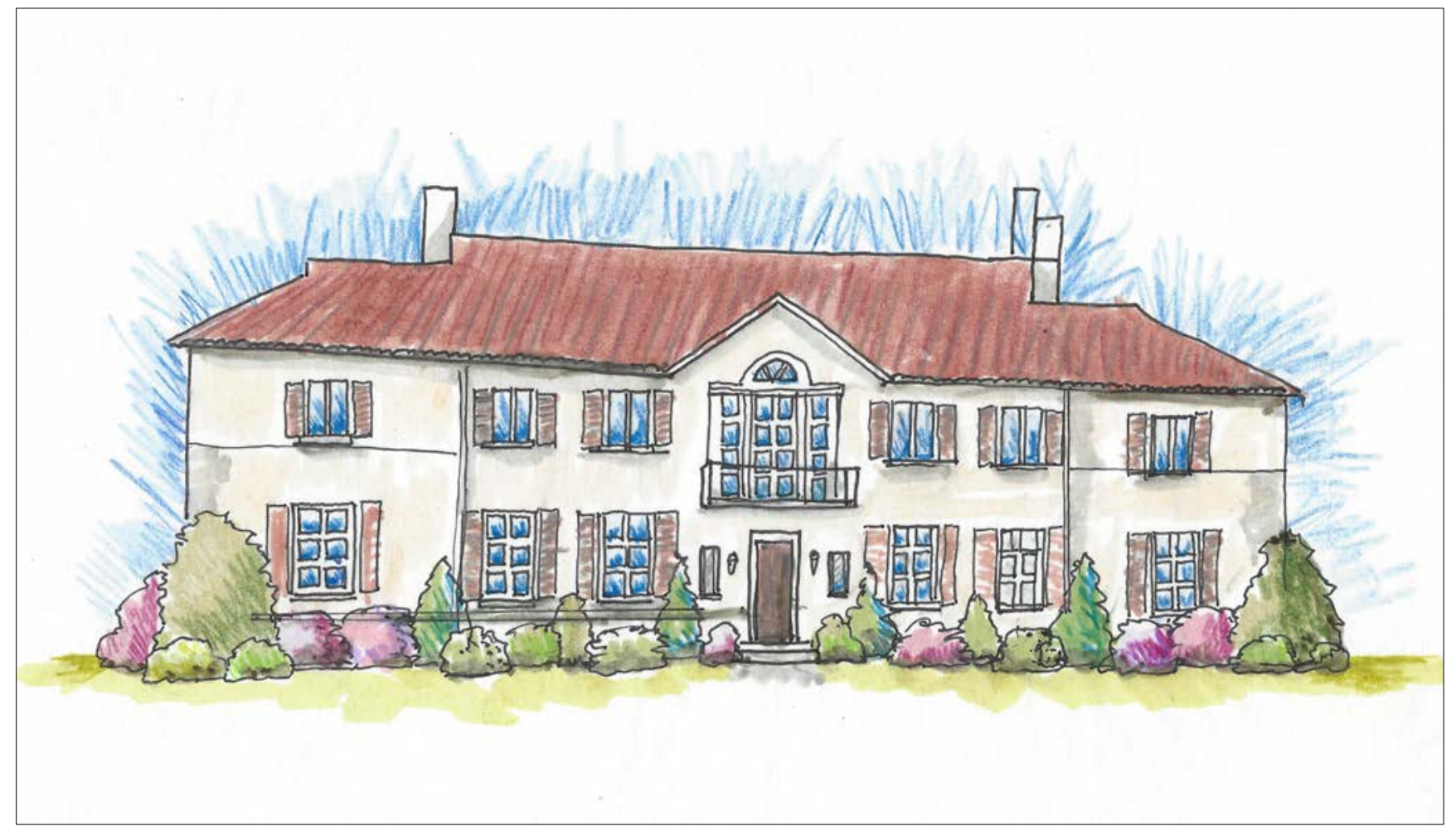

\subsection{Small-scale features}

\subsubsection{Monuments and memorials}

A master plan for monuments and memorials should be completed as soon as possible and prior to the approval for locating any new monuments and memorials.

Zone 1. Adding new monuments and memorials should not happen in Zone 1. For example, the open space between Wiley Hall and the water is an important historic landscape and viewshed. This open space and views should be preserved and remain free of obstructions and clutter.

Zone 2. New monuments and memorials may be added outside the quadrangle area. For visual consistency, no new monuments and memorials should be added within Zone 2, to allow freedom for drill and ceremonial uses. Replacement trees may be potential memorials, but trees should not be added in new locations without SHPO consultation.

Zone 3 and Zone 4. Monuments and memorials may be added. 


\subsubsection{Fencing}

Historically, the Academy's boundary was fenced with a wood fence. Today, many different types of fencing are used throughout the Academy's landscape-most notably new chain-link fencing where security and safety have deemed it necessary (Figure 137). Other types of fencing may be more appropriate in the Historic District and the Academy's more visible areas; an example would be using black fencing to match handrails and site furnishings.

Zone 1 and Zone 2. In-kind replacement or repair of historic fencing material is recommended. Fencing should be in historic locations. No new fencing types are recommended. If new fencing is required, such a change would require consultation with SHPO and selection of a historically appropriate material such as black fencing to match existing handrails or other site furnishings in the Historic District.

Zone 3 and Zone 4. While consultation and material consistency may not be necessary, compatible materials to those in the Historic District are ideal so that there is visible continuity throughout the Academy's landscape.

Selection of one or two types of fencing is recommended for use throughout the Academy. 
Figure 137. New chain-link style of fencing material in quad area of the USMMA Historic District (ERDC-CERL, 2017).

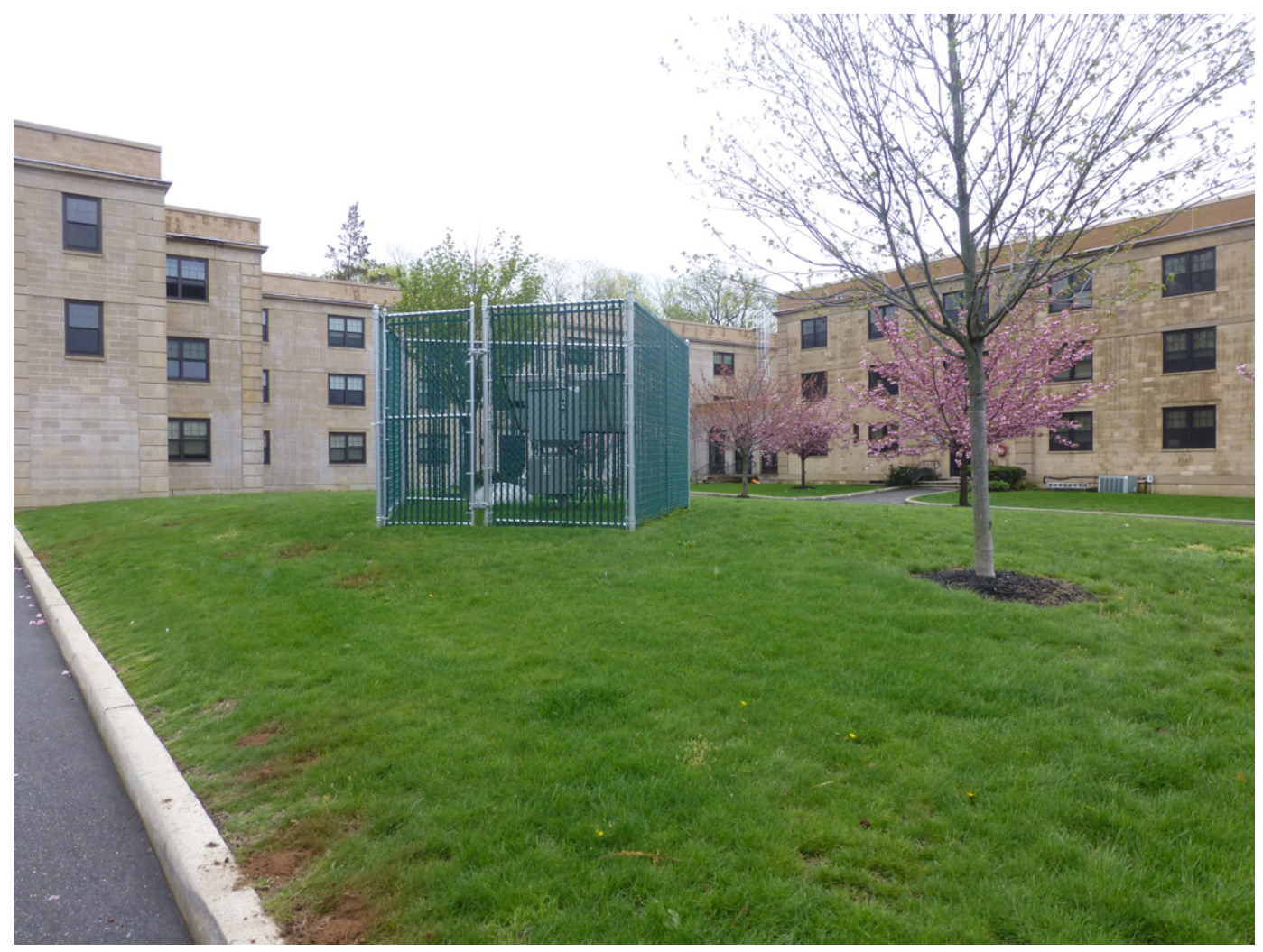

\subsubsection{Lighting and site furnishings}

In-kind replacement, repair, or removal is allowed throughout for utility poles and street and parking lot lighting fixtures that are not characterdefining features of a historic property.

Zone 1. The addition of new site furnishings should be kept to a minimum in Zone 1. For example, the grove of trees between Wiley Hall and the library is an important historic landscape and viewshed. This grove and views through the grove should be preserved and kept free of obstructions and clutter.

Zone 2. New site furnishings may be added outside the quad area. For visual consistency, site furnishings should be kept to a minimum in this area to allow for views to remain open and to maintain freedom for drill and ceremonial uses. 
Zone 3 and Zone 4. Lighting and site furnishings may be added in any location. Compatible materials to those in the Historic District are ideal so that there is visible continuity throughout the Academy's landscape.

NOTE: Selection of one or two styles of furnishings for benches, trash receptacles, bollards, and lighting is recommended for use throughout the Academy. 


\section{Conclusion}

This document meets the requirements for federal agencies to address their cultural resources, which are defined as any prehistoric or historic district, site, building, structure, or object. An especially relevant requirement met by this report is Section 110 of the NHPA, which requires federal agencies to inventory and evaluate their cultural resources.

The Academy and its Historic District are well maintained, and its historic developments are clearly seen in the physical landscape. Although the Academy's Historic District has undergone change over the years, the overall quality and characteristics of the area have remained consistent.

This report documents the historic landscapes of the Academy and evaluates them for their significance and historic integrity. This report identifies several landscapes that are significant to the history of Long Island's Gold Coast and to the history of the Academy. Four landscape preservation zones were identified (Zones 1-4), and best management practices were identified for each of the zones, including vegetation, fencing, and future additions of monuments and memorials to the landscape. In addition, recommendations have been made to help preserve the historic characteristics of the Academy as well as to allow more historically appropriate modifications in the future. A plant list has been generated based on the historic landscape context, and it incorporates currently acknowledged pest-free, disease-free, and sustainable plant material. (See Appendix A for plant list.)

This report should be used in conjunction with the draft Programmatic Agreement 3 to determine adverse effects.

\footnotetext{
3 Programmatic Agreement Among the U.S. Merchant Marine Academy, The New York State Historic Preservation Officer, and the Advisory Council On Historic Preservation Regarding Operations, Maintenance, and Development Activities at U.S. Merchant Marine Academy, Nassau County, New York.
} 
(Intentionally blank.) 


\section{References}

\section{Cited in text}

“Grenwolde, Great Neck, Long Island.” 1913a. House and Garden February: 82.

“Grenwolde, Great Neck, Long Island.” 1913b. House and Garden March: 160.

“House, Mrs. C.H. Smithers, Great Neck, L.I.” 1915. Architecture June 31(6).

“A Home at the Water's Edge.” 1919. Arts \& Decoration February: 213.

Loechl, Suzanne K., Susan I. Enscore, Megan W. Tooker, and Samuel A. Batzli. 2009. Guidelines for Identifying and Evaluating Historic Military Landscapes. ERDC/CERL TR-09-6. Champaign, IL: Engineer Research and Development Center-Construction Engineering Research Lab.

The Louis Berger Group Inc. 2005. Cultural Resources Survey Report, U.S. Merchant Marine Academy, Kings Point, New York. Lester, PA: prepared for Naval Facilities Engineering Command.

MacKay, Robert B., Anthony K. Baker, and Carol A. Traynor. 1997. Long Island Country Houses and Their Architects. New York: W.W. Norton \& Company.

NPS (National Park Service). 1991. National Register Bulletin \#15, How To Apply the National Register Criteria for Evaluation, Washington, DC: U.S. Department of the Interior, National Park Service.

.2000. Preservation Brief \#36: Protecting Cultural Landscapes. Prepared by Charles A. Birnbaum. Washington, DC: U.S. Department of the Interior, National Park Service.

Pincus, Roberta. 1975. This is Great Neck: History of the Great Neck Community from 16oo-Present. Great Neck, Long Island, NY: League of Women Voters of Great Neck.

Smith, Adam D., Susan I. Enscore, and Megan W. Tooker. 2014a. Character-Defining Features in the United States Merchant Marine Academy Historic District. ERDC/CERL SR-14-5. Champaign, IL: Engineer Research and Development Center-Construction Engineering Research Laboratory.

. 2014b. The United States Merchant Marine Academy Historic District: Nomination to the National Register of Historic Places. ERDC/CERL TR-14-28. Champaign, IL: Engineer Research and Development Center-Construction Engineering Research Laboratory. . 2014c. William Barstow Mansion of the United States Merchant Marine Academy: Nomination to the National Register of Historic Places. ERDC/CERL TR-14-29. Champaign, IL: Engineer Research and Development CenterConstruction Engineering Research Laboratory. 
U.S. Coast Guard. 1942. "Map of Property: Merchant Marine Academy, Great Neck, New York.” July 1942. RG 178, U.S. Maritime Commission, Division of Training, Maritime Training Subject Files, 1938-1951, Box 2, Folder: Academy Expansion. College Park, MD: National Archives and Records Administration.

USMMA. 1975. Kings Point Newsletter. 1975.

\section{Resources consulted}

NPS (National Park Service). 1918. Guide to Cultural Landscape Reports: Contents, Process, and Techniques. Credited authors: Robert R. Page, Cathy Al. Gilbert, Susan A. Dolan. Washington, DC: U.S. Department of the Interior, National Park Service.

.1997 (rev.) National Register Bulletin \#16A: How to Complete the National Register Registration Form. Washington, DC: U.S. Department of the Interior, National Park Service.

. n.d. National Register Bulletin \#18: How to Evaluate and Nominate Designed Historic Landscapes. Prepared by J. Timothy Keller and Genevieve P. Keller. Washington, DC: U.S. Department of the Interior, National Park Service.

. 1992. National Register Bulletin \#3o, Guidelines for Evaluating and Documenting Rural Historic Landscapes, Washington, DC: U.S. Department of the Interior, National Park Service.

. 1992. The Secretary of the Interior's Standards for the Treatment of Historic Properties. Washington, DC: U.S. Department of the Interior, National Park Service. 


\section{Appendix A: Plant List}

Table A1 provides a plant list for USMMA. Plants native to the United States and North America should be prioritized for planting. Resources that expand the current selection of plants for USMMA with native and regionally appropriate plants can be found through the Cornell University Extension.

Table A1. Plant list for USMMA.

\begin{tabular}{|c|c|c|}
\hline Scientific Name & Common Name & Native Status \\
\hline \multicolumn{3}{|l|}{ GROUND COVER } \\
\hline Cornus canadensis & Bunchberry & Native to North America \\
\hline Asarum canadense & Wild ginger & Native to North America \\
\hline Cornus canadensis & Bunchberry & Native to North America \\
\hline Geranium maculatum & Wild Geranium & Native to North America \\
\hline Huechera americana & Coral Bells & \\
\hline Liriope spicata & Creeping lilyturf & \\
\hline Juniperus horizontalis & Creeping Juniper & Native to North America \\
\hline Pachysandra procumbens & Allegheny pachysandra & Native to North America \\
\hline Rhus aromatic "Low Gro" & Low gro Sumac & Native to North America \\
\hline \multicolumn{3}{|l|}{ SHRUBS } \\
\hline Aronia arbutifolia & Red Chokeberry & Native to North America \\
\hline Aronia melanocarpa & Black Chokeberry & Native to North America \\
\hline Calycanthus floridus & Carolina Allspice & \\
\hline Clethra alnifolia & Summersweet & \\
\hline Comtonia peregrina & Sweet Fern & Native to North America \\
\hline \multicolumn{3}{|l|}{ Cornus alba } \\
\hline Hamamelis vriginiana & Witchhazel & Native to North America \\
\hline Hydrangea macrophylla & Big leaf hydrangea & \\
\hline Ilex crenata & Box leaf Holy & \\
\hline Ilex glabra & Inkberry & Native to North America \\
\hline Ilex verticillata & Winterberry & Native to North America \\
\hline Junniperus communis & Common Juniper & Native to North America \\
\hline Kalmia latifolia & Mountain Laurel & Native to North America \\
\hline Lindera benozoin & Spicebush & \\
\hline Myrica pennsylvanica & Bayberry & Native to North America \\
\hline Pinus strobus Nana & Dwarf White Pine & \\
\hline Prunus maritima & Beach plum & Native to North America \\
\hline Philadelphus caronarius & Mockorange & \\
\hline Rhododendron catawbiense & Catawba rhododendron & Native to North America \\
\hline Rosa carolina & Pasture rose & Native to North America \\
\hline Rosa virginiana & Virginia Rose & Native to North America \\
\hline Symphoricarpos orbiculatus & Snowberry & Native to North America \\
\hline Syringa meyeri & Meyer Lilac & \\
\hline Viburnum acerifolium & Maple-leaved Viburnum & Native to North America \\
\hline Viburnum carlesii & Korean Spice Viburnum & \\
\hline Viburnum dentatum & Arrowwood & Native to North America \\
\hline
\end{tabular}




\begin{tabular}{|c|c|c|}
\hline Scientific Name & Common Name & Native Status \\
\hline Acer rubrum & Red Maple & Native to North America. \\
\hline Acer saccharum & Sugar Maple & Native to North America. \\
\hline Amelanchier canadensis & Coastal Shadbush & Native to North America. \\
\hline Amalanchier laevis & Smooth Shadbush & Native to North America. \\
\hline Betula lenta & Sweet Birch & Native to North America. \\
\hline Betula populifolia & Gray Birch & $\begin{array}{l}\text { Native to the eastern United } \\
\text { States. }\end{array}$ \\
\hline Catalpa speciosa & Northern Catalpa & Native to North America \\
\hline Carya glabra & Pignut Hickory & Native to North America \\
\hline Cercis canadensis & Redbud & Native to North America. \\
\hline Chamaecyparis thyoides & Atlantic White Cedar & Native to North America. \\
\hline Cornus alternifolia & Pagoda Dogwood & Native to North America. \\
\hline Cornus florida & Flowering Dogwood & Native to North America \\
\hline Crateagus crus-gali & Cockspur Hawthorn & \\
\hline Crataegus mollis & Downy Hawthorn & Native to North America. \\
\hline Fagus grandiflora & American Beech & Native to North America. \\
\hline Fraxinus americana & White Ash & \\
\hline Fraxinus pensy/vanica & Green Ash & Native to North America \\
\hline Ilex opaca & American Holly & Native to North America \\
\hline Juglans nigra & Black Walnut & Native to North America \\
\hline Juniperus virginiana & Eastern Red Cedar & Native to North America. \\
\hline Liquidambar styraciflua & Sweetgum & Native to North America. \\
\hline Liriodendron tulipifera & Tulip tree & Native to North America. \\
\hline Nyssa sylvatica & Tupelo & Native to North America \\
\hline Picea albies & Norway Spruce & \\
\hline Pinus strobus & White Pine & Native to North America \\
\hline Platanus $x$ acerifolia & London Planetree & \\
\hline Populus tremuloides & Aspen & Native to North America \\
\hline Prunus serotina & Blacks Cherry & Native to North America \\
\hline Quercus alba & White Oak & Native to North America \\
\hline Quercus cocciniea & Scarlet Oak & Native to North America \\
\hline Quercus montana & Chestnut Oak & Native to North America \\
\hline Quercus stellata & Post Oak & Native to North America \\
\hline Quercus velutina & Black Oak & Native to North America \\
\hline Tilia americana & Basswood & Native to North America \\
\hline Thuja occidentalis & Eastern Arborvitae & Native to North America \\
\hline
\end{tabular}




\section{Appendix B: Historic Landscape Development}

This appendix provides a reference for the significance of the USMMA historic landscape and if needed, used in consultation with the SHPO.

\section{Garden landscapes of the Gold Coast estates, 1915-19394}

Beginning in the last quarter of the nineteenth century, Nassau County, New York, was part of what became known as the "Gold Coast" on Long Island's North Shore. Wealthy New Yorkers established elaborate estates in the area, which offered easy commuting distance to downtown Manhattan (Figure B1). Between the Civil War and WWII, over 900 estates were developed on Long Island, between Queens and the western border of Nassau County and the village of Montauk on the eastern end of Long Island. Most of these estates were summer retreats from which the residents returned to their city dwellings during the winter. Great Neck and Kings Point were part of this development, and many of these early twentieth-century estates survive today.

Figure B1. Map of estates along the water in Great Neck, NY, circa 1920 (Pincus $1975,148)$. Note that the Academy site has been shaded in red (added).

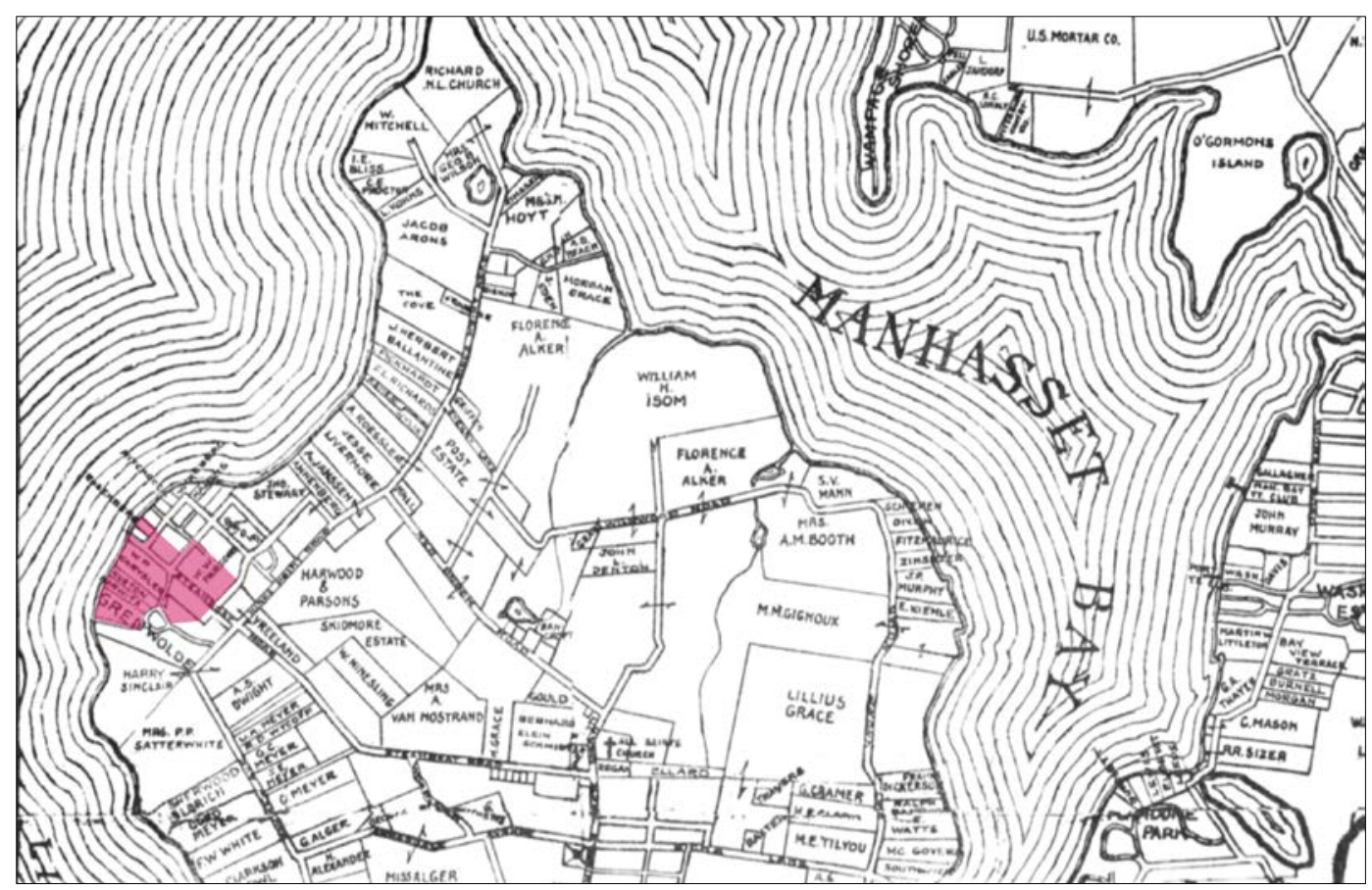

\footnotetext{
${ }^{4}$ Material in this section is taken from Smith et al. 2014b (see Reference list). Figure numbering, however, is unique to this document.
} 
For a majority of the North Shore's Gold Coast estates, landscape design was an essential component of the overall master plan. Some of the estates exhibited formal classical gardens, while others were predominantly naturalistic or picturesque. Some of the estates contained both kinds of designed landscapes. Many of the estate owners hired expert landscape architects such as the Olmstead brothers, Marian C. Coffin, James Leal Greenleaf, Charles W. Leavitt, and Ellen B. Shipman. The more formal landscapes were focused on axial vistas. 5 The plantings tended to be geometric in design. The more natural landscapes utilized the site's native materials and physical characteristics as design inspiration. Irregularity and unexpected openings/closures were typical of this style. Links between the inside and outside were strongly considered in the designs.

The railroad was a dominant factor in the evolution of Long Island from a largely rural farming area into a thriving residential area. By 1865 , railroads were constructed across the center of Long Island and along the north and south shores. By the turn of the twentieth century, the Long Island Rail Road (LIRR), which began construction in 1834, was the dominant means of transportation to New York City. In 1911, the railroad completed direct rail service to Pennsylvania Station in the heart of Manhattan, and the population of the small villages of Long Island's Nassau County along the LIRR lines swelled with commuters.

Although rail transportation was preferred by commuters, many of Kings Point's residents traveled to their city jobs by steamboat, because the landing off Elm Point proved to be more conveniently located than the rail station. As early as 1859 , a steamboat landing was located at the end of present-day Steamboat Road, which runs through the USMMA campus (Figure B2). Boats left the landing at 8:00 a.m. and returned at 6:00 p.m. The boat schedules, however, were subject to seasonal weather delays. The landing and an adjacent park remained open to the public until the establishment of USMMA in 1942.

\footnotetext{
${ }^{5}$ Axial views are views in alignment with a focal point, usually between the mansion and the ocean, or views between the mansion and a vegetative screen of some kind.
} 
Figure B2. Steamboat Road Pier, 1890 (Bland Library USMMA).

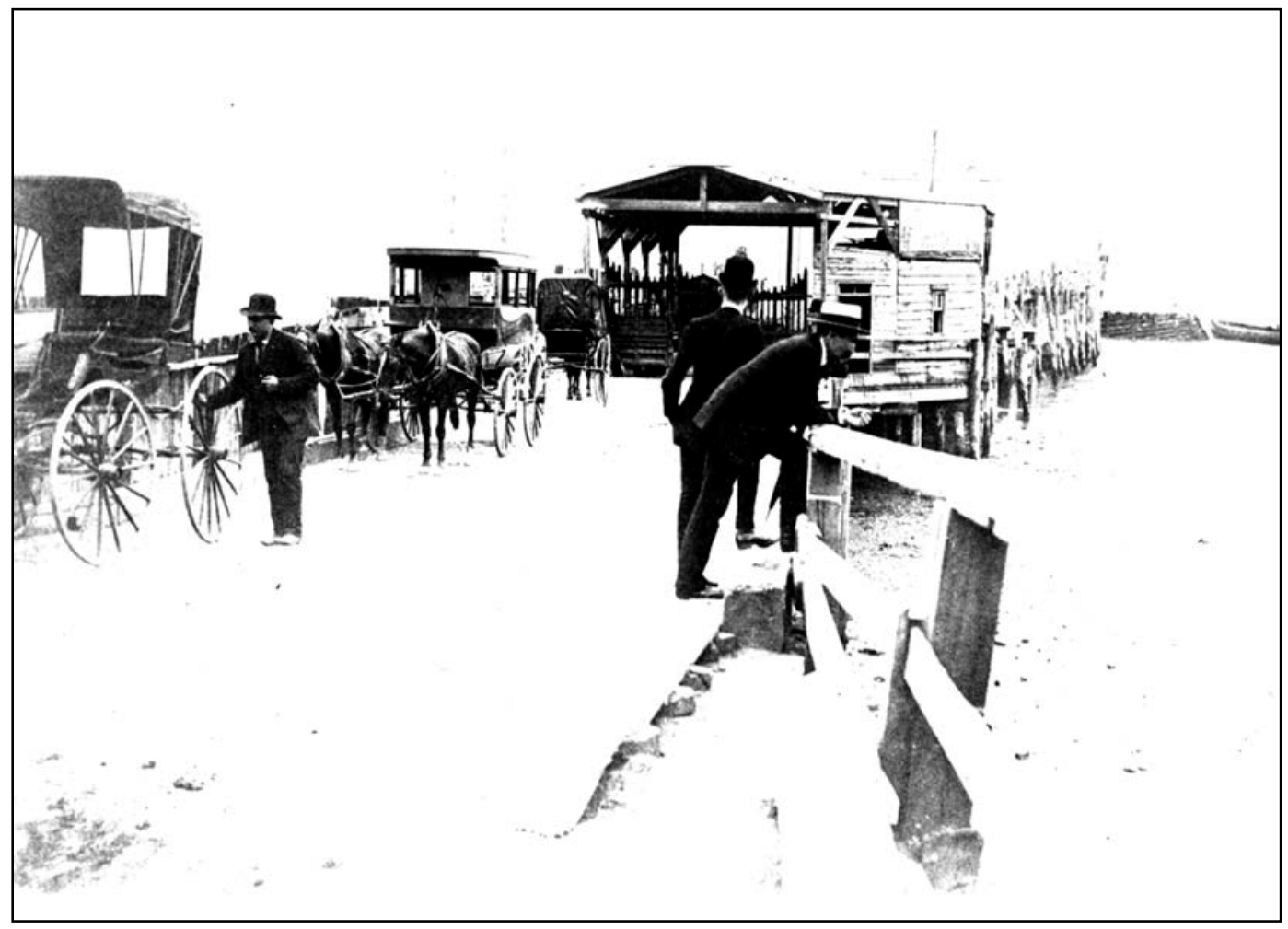

By the mid-twentieth century, a major redevelopment of the east-west automobile parkway systems, which were created just before WWII, was supplemented by the creation of additional north-south parkways and the Long Island Expressway. Automobile travel also was bolstered by the construction of bridges over the East River. Increased automobile access was a stimulus for additional residential construction. With increased industrial opportunities after WWII and such mass housing developments as Levittown, which held over 10,000 new homes, Nassau County's population continued to grow throughout the 1940s. What at first had been a retreat only for wealthy city dwellers soon became accessible to the middle class. At Kings Point, one of the developments for the middle class was called Grenwolde.

The Grenwolde development's plot map was filed with Nassau County on 10 October 1913 (U.S. Coast Guard 1942). Grenwolde was part of a boom during the 1910 s in Great Neck land sales for country estates. The development was controlled by the Great Neck Shores Corporation. Planning and construction was underway before that time, as a series of advertisements for the development had appeared in House and Garden magazine that spring. The ads were geared toward the New York City 
resident who desired a country haven but could not afford a large estate. The ads invoked the romantic notion of English country houses by using phrases such as "the fascination that impels the tourist to linger amid the hedgerows and by-ways of the English countryside finds its counterpart at Grenwolde, Great Neck, Long Island" ("Grenwolde" 1913a:82). In the ads, the lots were described as "generous in size, unique in shape and outlook, and lend themselves readily to individual treatment in landscaping and architecture" ("Grenwolde" 1913b:160). The revival styles of the homes reflected the old-world charm the developers sought to present. Grenwolde was an exclusive community, with property restrictions and purchase conditions, as well as an owners association. The Grenwolde development stretched south from the Chrysler estate to include four more estates. The development then encompassed a circle to the east and a line of properties north of the circle (Figure B3). Included in the Grenwolde development were the Nicholas M. Schenck estate (now Land Hall), the Charles Neiley estate (now Quarters A and Quarters J), Colen house (Quarters B), Vreeland house (Quarters C), and a Casino (now Quarters D).

In 1915, retail magnate Henri Willis Bendel purchased property to build a house on Kings Point, adjacent to Grenwolde. Prior to Bendel's purchase, the property went through a series of owners. An insurance map from 1914 shows the property as owned by C.N. Busch, with a two-story house; a 1915 New York Times article about the sale mentioned an existing, large, brick and stone dwelling with a purchase price for the property of $\$ 150,000$. The house, which today stands as Wiley Hall, was built in 1916 for Bendel and was designed by architect Henry Otis Chapman of New York City; Chapman also designed two other country-house estates on Long Island. The Bendel house features such typical design elements of Beaux Arts classicism as columns, balustrades, loggias, quoins, Palladian windows, and detailed entablatures, and it is constructed of reinforced concrete finished with stucco. The interior reflects the grandeur of the early twentieth-century Gold Coast estates with a double-height entrance hall, elaborate fireplace surrounds, and carved and painted wooden ceilings. 
Figure B3. Chrysler estate at center, and Grenwolde development at right (note circle), 1932 (USMMA Bland Library).

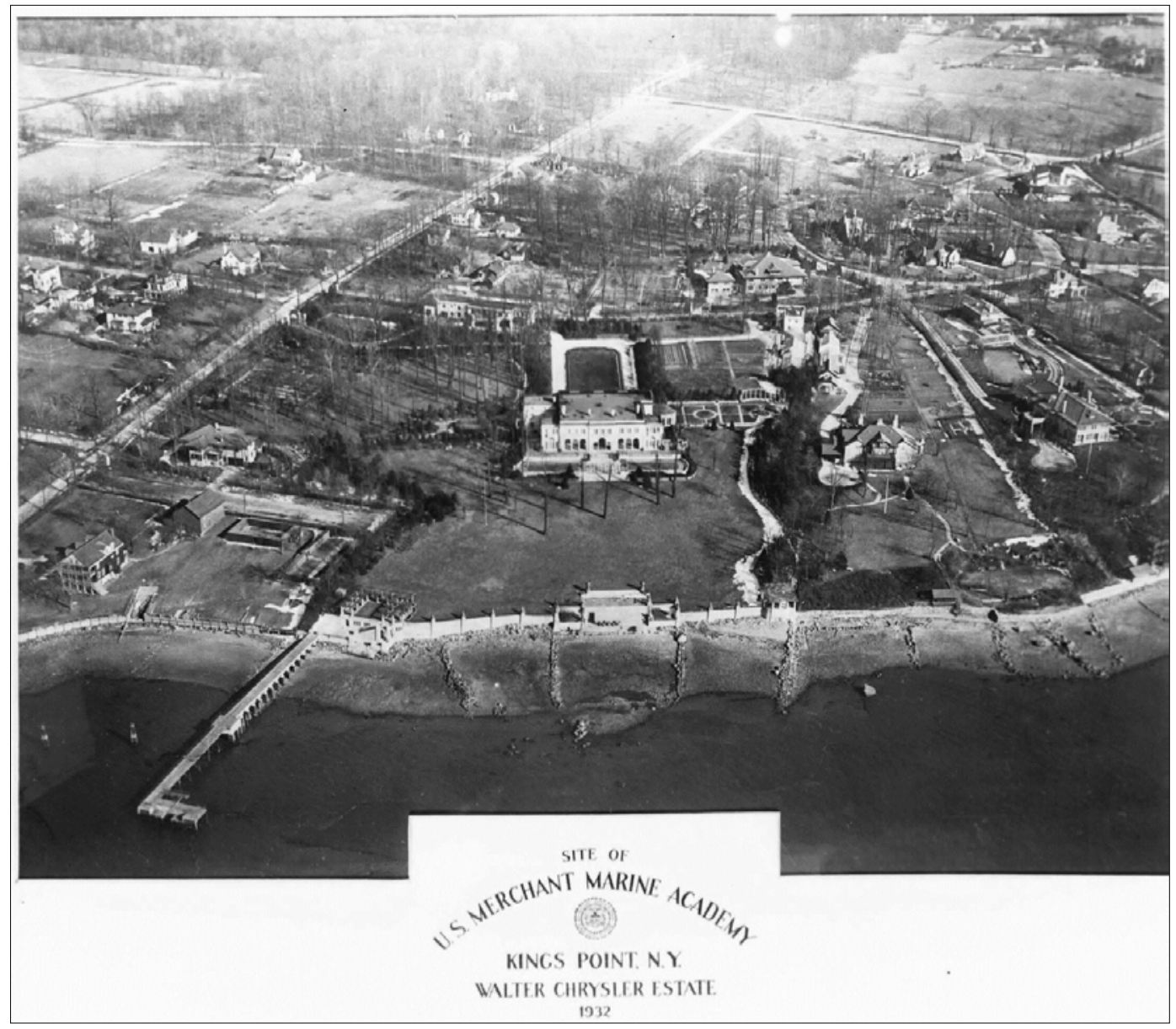

Bendel sold the Kings Point property in 1923 to Walter Percy Chrysler and Della V. Forker Chrysler, his wife. The Chryslers named their new property Forker House. Walter Chrysler, a former vice president at General Motors until 1919, began making his own cars in 1924 and formed the Chrysler Corporation in 1925. Walter Chrysler ran the company on a day-to-day basis until 1935, when he retired as president and became chairman of the board. Three years later, he retired completely after a stroke. His wife Della, with whom he had four children, died in 1938; Chrysler followed her in death in 1940, dying at home. The heirs put the property on the market in 1941 (Figure B4). 
Figure B4. View from the water toward the Chrysler estate, 1941, as shown in sales brochure (USMMA Bland Library).

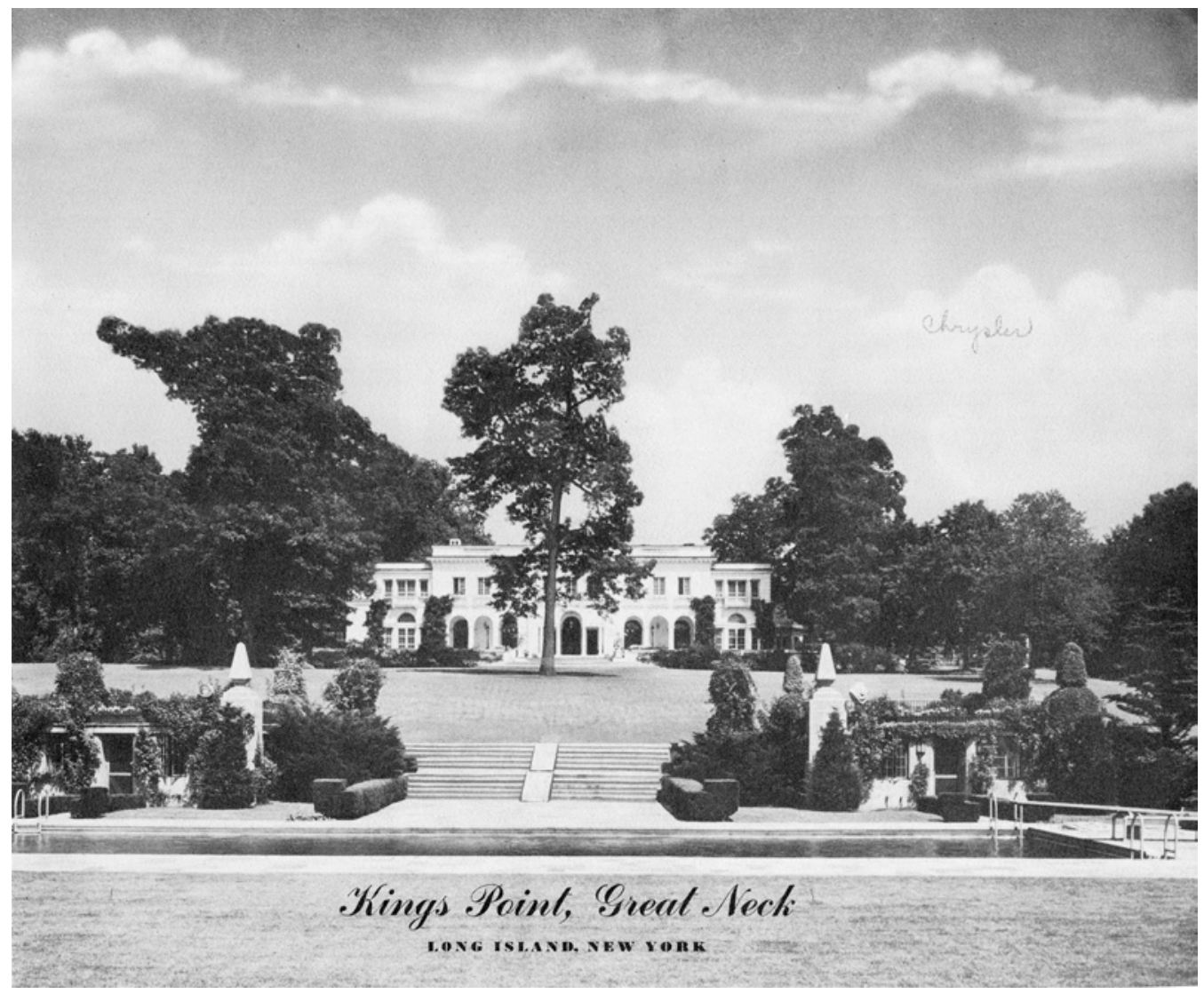

At the time of the sale, the 12-acre estate contained a garage (with three apartments on the second floor), a superintendent's house, a greenhouse (Figure B5), and the main house at the center of the estate. Toward the waterfront, there was a separate recreation building near the pier, a large saltwater outdoor pool, a boat house, and 2 bathhouses. The grounds contained several large areas of lawn with paved terraces (Figure B5). A formal sunken garden with lawn and ornamental plantings was located at the main entry east of the house and had steps at its eastern end leading up to a fountain or statuary. There was also a formal rose garden to the south of the house (Figure B6), with an exedra at the southern end. The Amphitrite Fountain currently located at the eastern end of the formal lawn to the east of the house was likely originally set at the end of the exedra, but it was moved when the Academy's construction began (Berger 2005, Appendix B). The fountain is cruciform in shape, and it contains a female statue representing the mythological goddess Amphitrite, "queen of the sea" and Poseidon's wife (Berger 2005, Appendix B). The 3 acres across the road from the estate's main gate (also owned by the Chryslers) 
were being used for a greenhouse and vegetable garden (Smith et al. 2014b, 37).

In an album of photos of the Chrysler estate that was taken before construction of the Academy, it was noted that the estate had a "large expanse of wooded lawn." It also described the entrance gate as "stately and beautiful" and noted the excellent roads about the estate that were paved in "crushed stone which required little in the way of upkeep."6

Figure B5. Components of the Chrysler estate in 1941, as shown in sales brochure (cont'd on next page) (American Merchant Marine Museum).
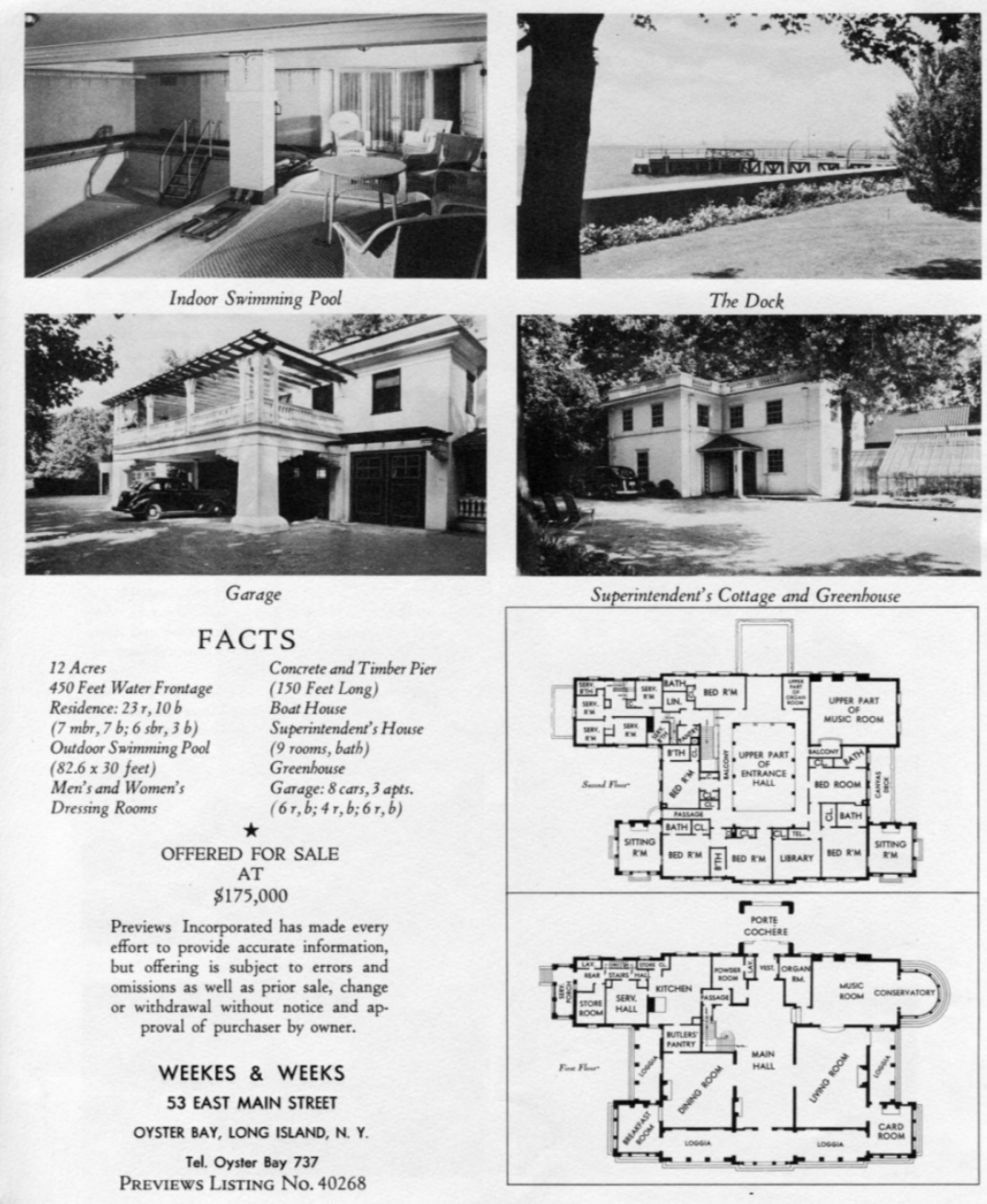

6 Photos taken by Nerney on 1 December 1941 (NARA, RG 178 Box 23, Correspondence). 


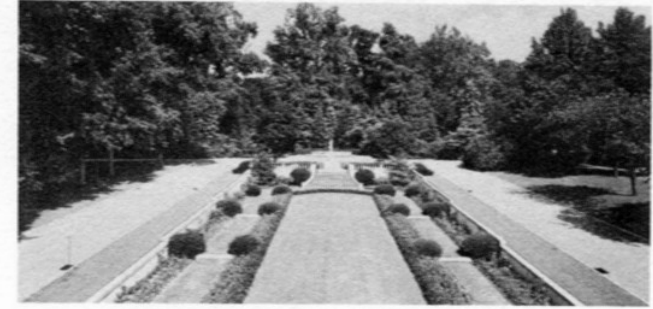

Sunken Garden

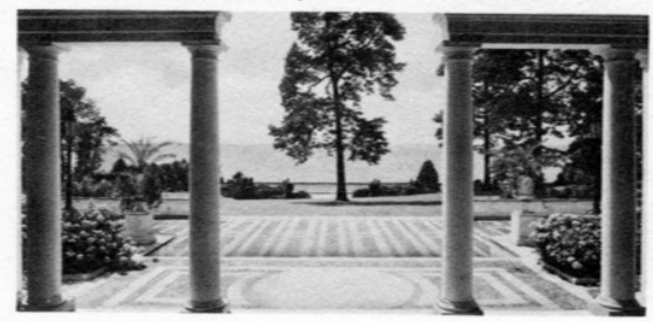

Sound View from Terrace

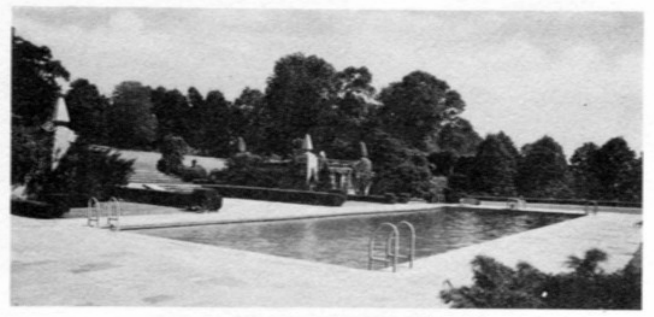

Swimming Pool

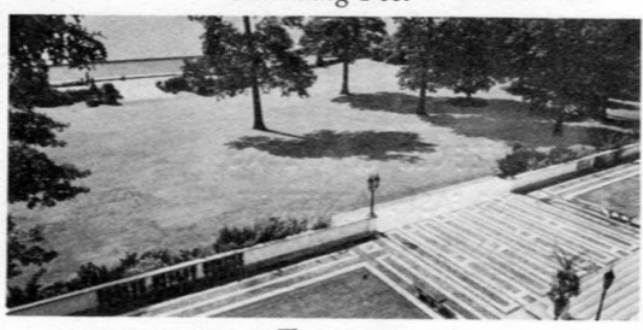

Terrace -

Figure B6. Rose garden south of Chrysler mansion, undated (Merchant Marine Museum).

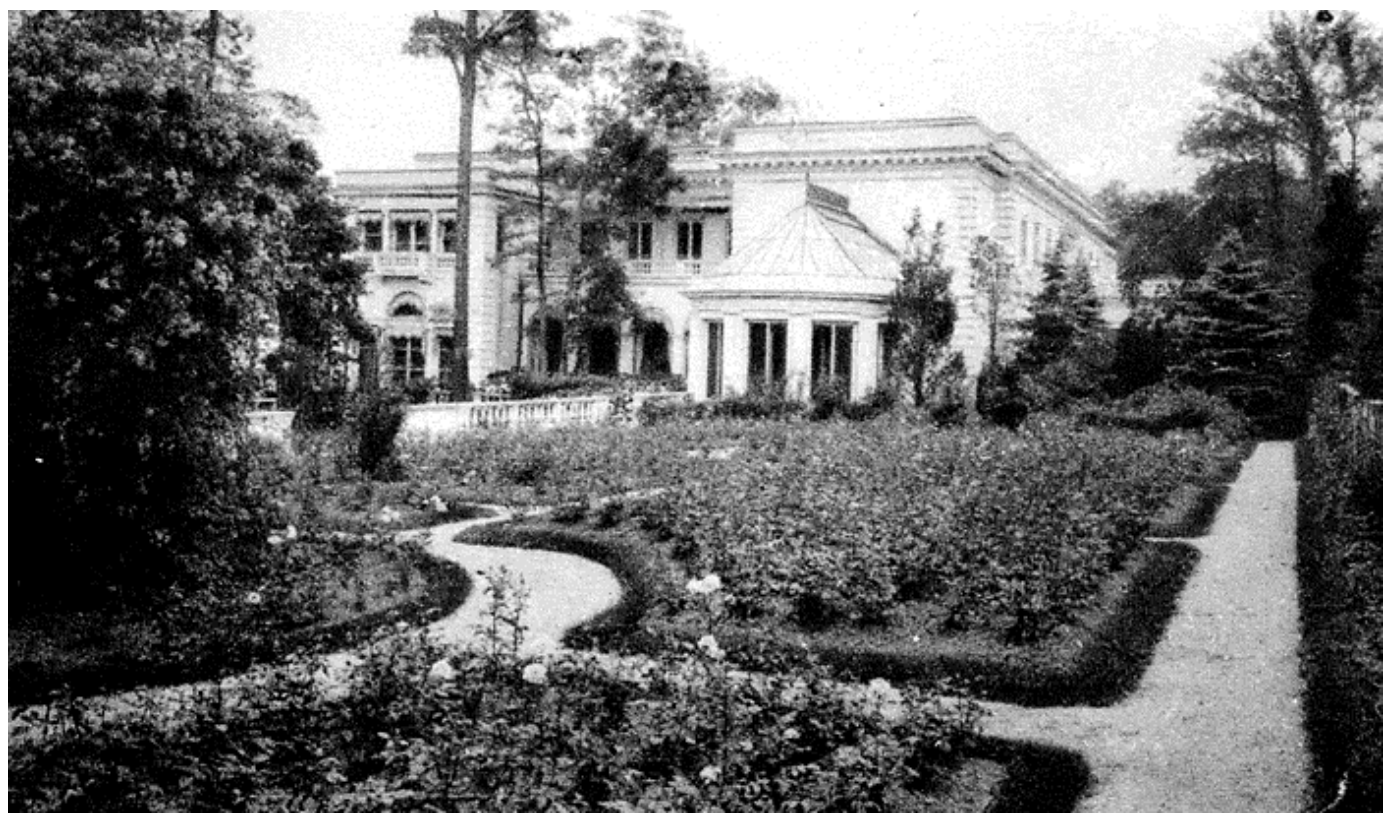

\section{Design and construction of the Academy, 1939-1941}

By late November 1941, the Chrysler estate had become the choice of the United States Maritime Commission (MARCOM) 7 and the Cadet School for the new Merchant Marine Academy. A 29 November 1941 Commission report provided the following major reasons for selection of the Chrysler property: (1) the Chrysler heirs were willing to consider government

7 An independent executive agency of the U.S. federal government that was created by the Merchant Marine Act of 1936 and replaced the United States Shipping Board, in existence since World War I. 
acquisition, (2) existing facilities could be utilized without delay for approximately 100 cadets, (3) sufficient space was available for additional construction and cadet drill, (4) it was a desirable location protected from heavy winds, and (5) there was an existing wooden and concrete pier (Smith et al. 2014b, 42).

With the sudden U.S. involvement in WWII following the 7 December 1941 Japanese attack at Pearl Harbor, MARCOM was placed on a war footing, and a quick expansion of facilities for officer and cadet training was essential.

On 15 January 1942, an option-to-purchase agreement granted MARCOM the right to begin using the property upon execution of the agreement, which occurred the following day. This occupancy was at no cost if the option to purchase was exercised; if not, the government agreed to pay the sellers \$25,000 in rent for the time period of 15 January-15 July. The Chrysler estate was formally acquired by the government on 29 June 1942.

Shortly after plans to acquire the Chrysler property were initiated, officials also sought to acquire several surrounding properties for the new Academy (Figure B7). The first group of properties marked for requisition consisted of the Schenck, Marchant, Colen, and Friedman lots in Grenwolde, and a series of lots east of the Chrysler estate and adjoining Grenwolde, not all of which were improved. These lots included a Grenwolde Association property containing a sewage station and the Kings Point village police station property with station, jail, and garages. 
Figure B7. View of USMMA acquisitions with handwritten owners' names, 1932 (USMMA Bland Library).

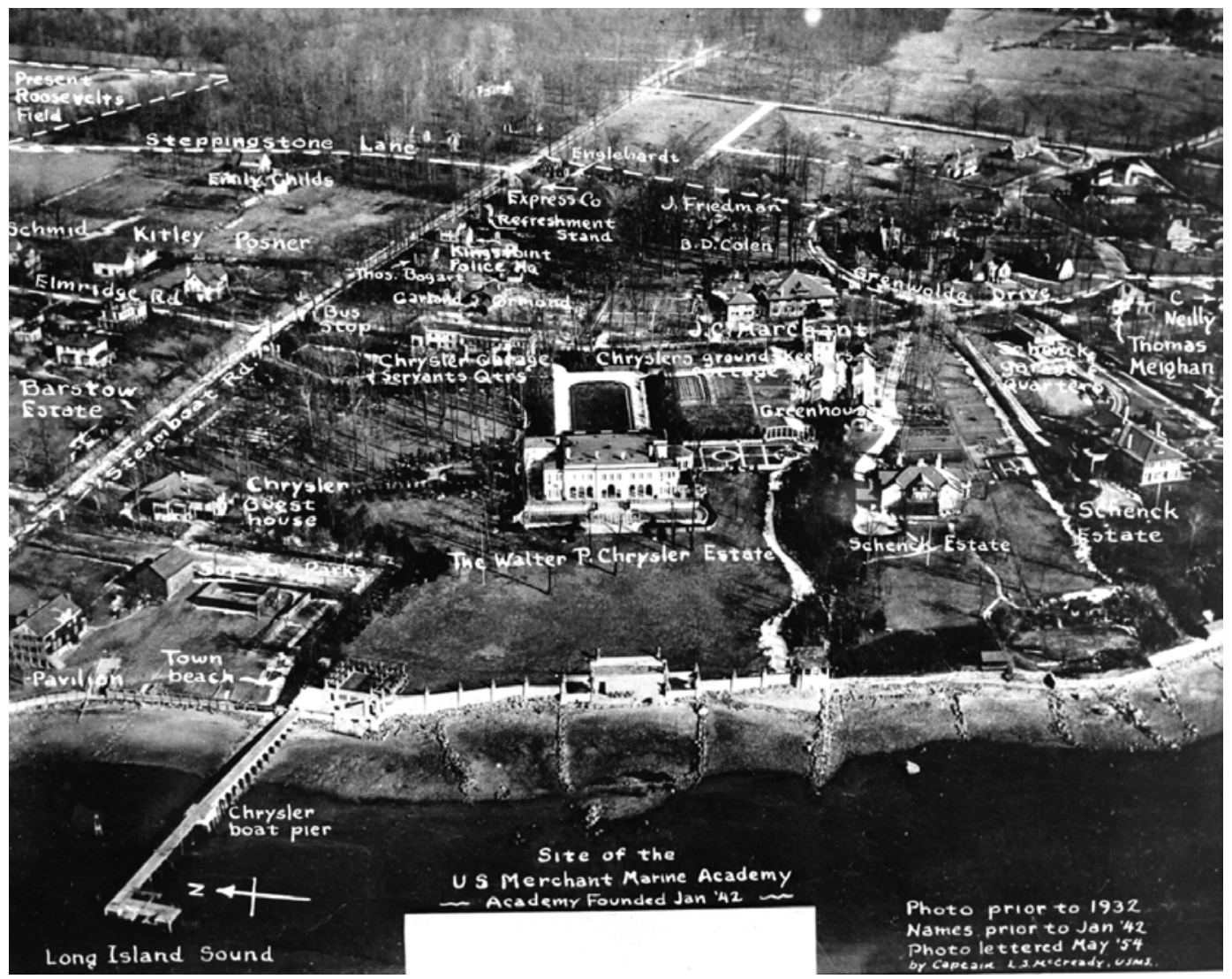

Efforts to acquire a drill and athletic field for the USMMA began in early April 1942. A 10-acre field existed across Steamboat Road from the proposed location of the drill hall and gymnasium; the property contained two houses, a garage, and a barn. An area adjacent to the field, which contained eight houses, was selected for its potential to house the Superintendent, the Commandant, and the department heads. USMMA began the immediate acquisition of these properties for the athletic field with baseball and softball diamonds, tennis courts, wooden bleachers, and a fence around the field with gates on four sides. It was September 1942 before the last of these properties was acquired.

The government also acquired the property just north of the Chrysler waterfront property in September 1942 that had been previously owned by the Town of North Hempstead and the Board of Park Commissioners of the Great Neck Park District. This area included the old wooden steamboat pier which had a small wooden pavilion, a public bathing beach, and bathhouses at the end of Steamboat Road (Figure B8). The remaining properties including the Meighan Estate, Neiley Estate, and Grenwolde 
Casino were acquired by 1943. The Meighan Estate was needed to house the Education Unit, the Neiley property was needed to construct a permanent medical clinic, and the casino was adapted for immediate use as a dispensary.

As soon as possible in January 1942, 103 midshipmen from Fort Schuyler began arriving on the new USMMA campus. By March, there were over 220 midshipmen on campus; in April there were 500; and by October 1942, there were approximately 1,000 midshipmen at Kings Point (Smith et al. 2014b, 42). Plans were immediately drawn up for utilizing the Chrysler mansion (Wiley Hall) for barracks, messing, and classrooms. In addition, they utilized a combination of existing buildings and temporary Civilian Conservation Corps (CCC) structures scattered around the central area of the Academy (Figure B9 and Figure B10).

Figure B8. Map of property in Kings Point showing lot owners, July 1942 (Berger 2005, 19).

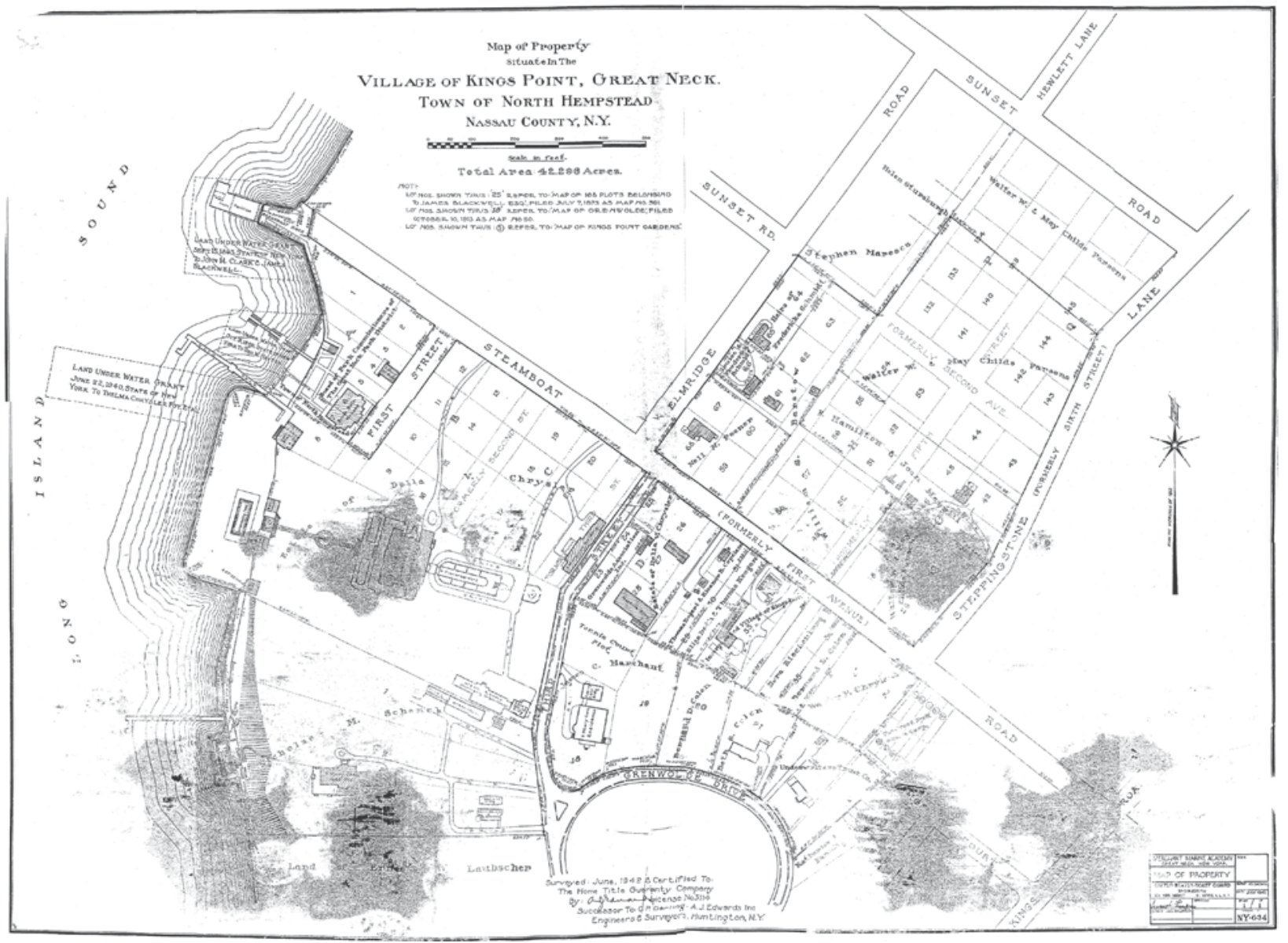


Figure B9. Plan showing existing buildings and Civilian Conservation Corps structures, August 1942 (USMMA Bland Library).

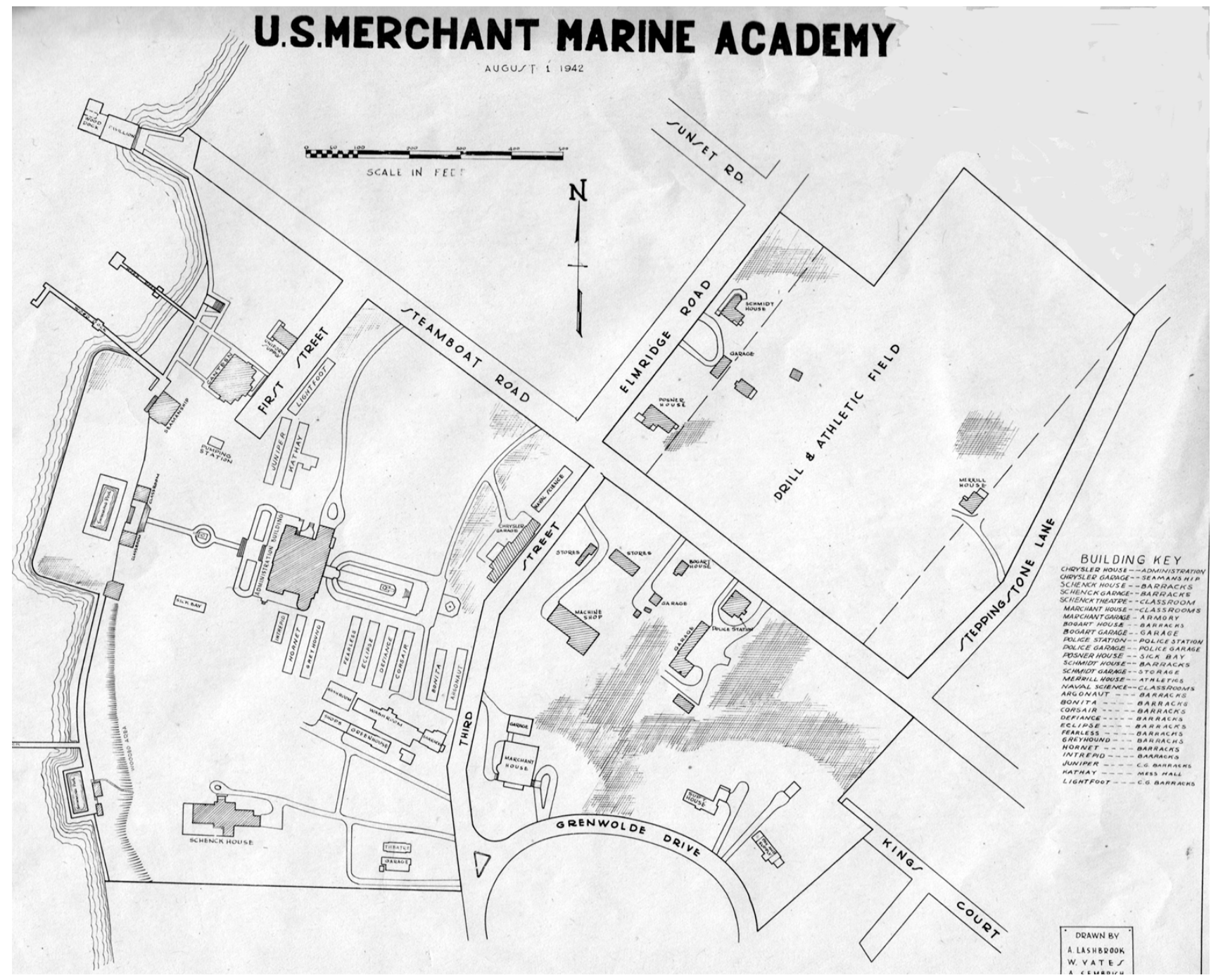


Figure B10. Plan showing new construction overlaid on existing buildings, 1942 (USMMA Bland Library).

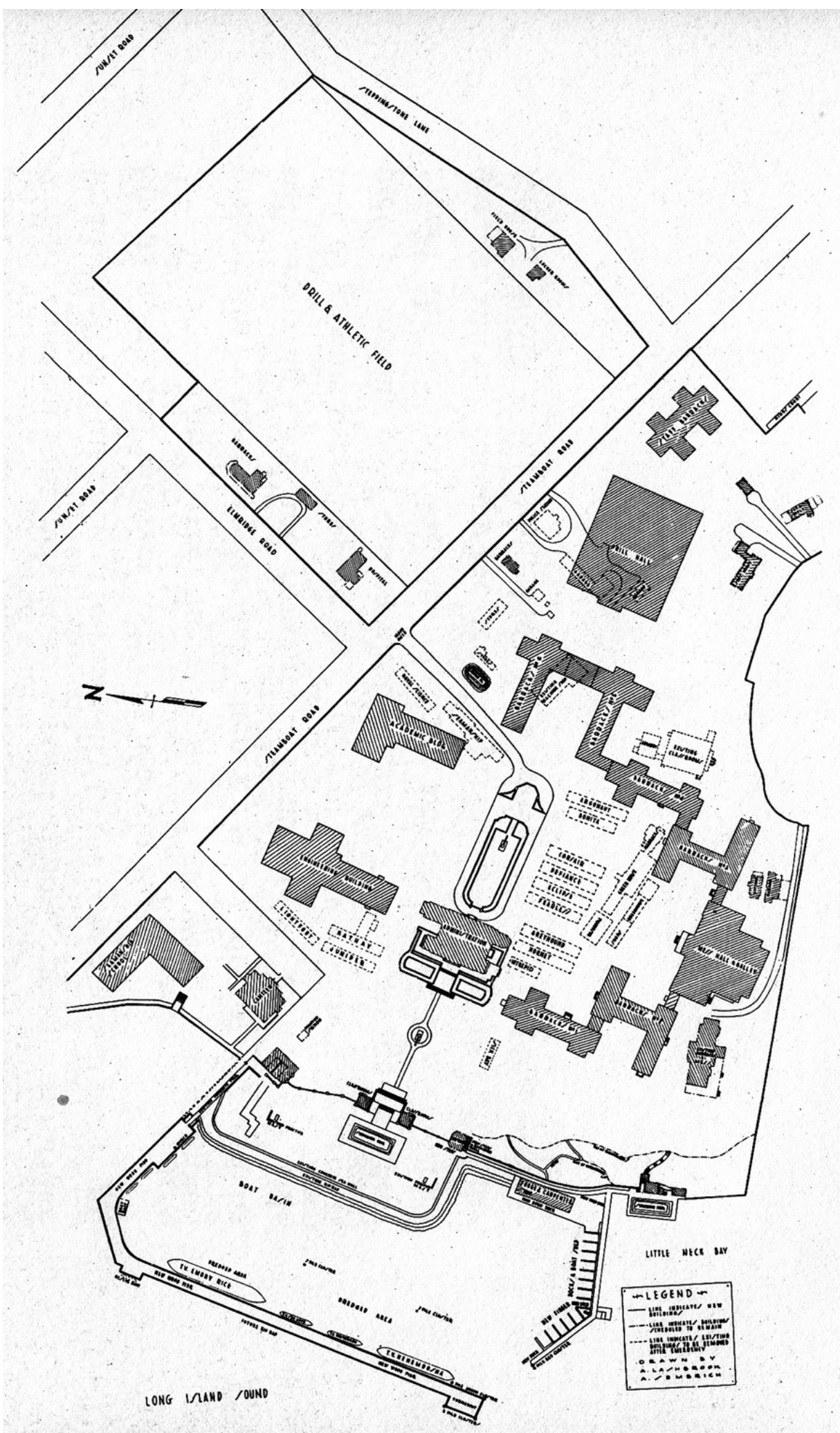


Cadets were berthed in six CCC barracks, briefly in the Chrysler mansion, the Chrysler superintendent's house, the Chrysler garage, the Schenck main house and garage, and the Marchant house and garage. Cadet mess halls were placed in a CCC building and on the lower floor of the Schenck house. Classes were taught in four CCC buildings, as well as the Chrysler garage, greenhouses, playhouse, and billiard room. In 1943, the Neiley house became home to the USMMA's superintendent (Quarters A). Even the Chrysler bathhouses were converted to classrooms. Eventually, the barracks facilities in existing buildings were gradually moved into the CCC structures as the interiors of existing buildings were converted into classrooms. The Chrysler garage became the location for seamanship classes, and engineering courses were taught in the Marchant house with its garage becoming the armory. In later years, the Friedman property became Quarters C, the Meighan house became Melville Hall (reconfigured for the Officers Club in the 1950s), and the Meighan garage became Quarters K. The Schenck house became Land Hall. The Neiley garage became Quarters L, and the casino property became Quarters D.

The west-side loggia of the Chrysler mansion (named Wiley Hall in 1943) was enclosed to provide a cadet entrance to the building. By midsummer, the mansion was primarily used for administrative purposes. The Chrysler grounds were altered by the removal of the south garden for CCC structures, which were also placed on the open lawn areas around the mansion for midshipman barracks and mess facilities. The eastern part of the sunken garden (now known as Powell Oval) was paved for a gun emplacement in July 1942, and a tall flagpole was added east of the gun. A new entrance road to the mansion was also completed in 1942. On the waterfront side, a new flagstone walkway between the mansion and the pool was in place by early July 1942. The flagstone path split around a large tree in the center of the lawn (Figure B11). A few years later, a memorial to commemorate all Kings Pointers who died in WWII was constructed in the oval area created by the split path. It was completed in 1946 with a gift from Bethlehem Steel, and the memorial is composed of a commemorative shaft with a bell and poised eagle. 
Figure B11. New flagstone walkway from Wiley Hall to pool, 1942 (USMMA Bland Library).

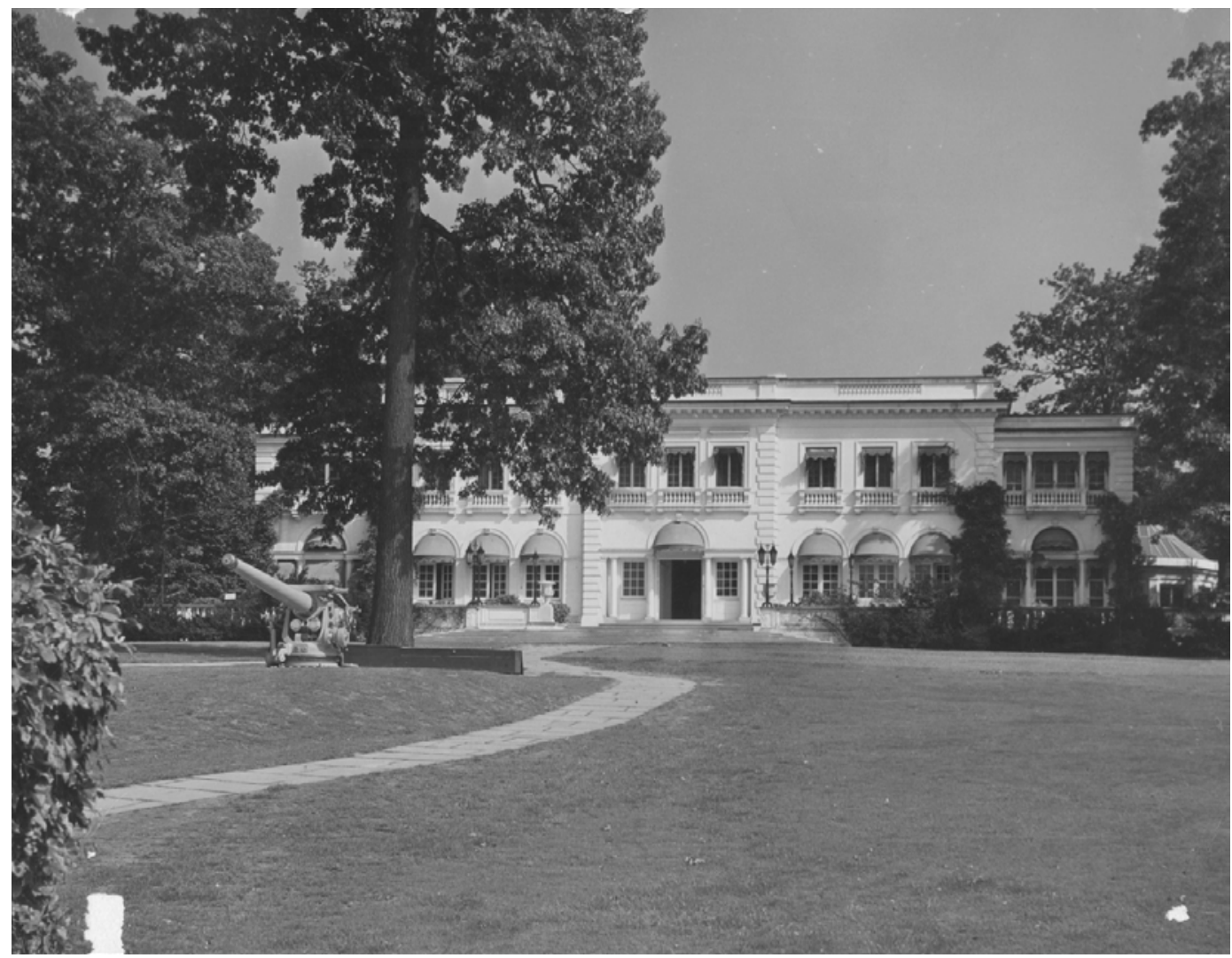

The waterfront facilities were greatly expanded, with the existing Chrysler pier (now known as Mallory Pier; Figure B12) enlarged to form the semienclosed Hague Basin, and a new pier was constructed on the south end of Chrysler estate waterfront with a covered pavilion (now Crowninshield Boat Shed). The former Schenck pool was enclosed for swimming instruction in cold weather.

By the end of May 1942, plans were made for enclosing USMMA in a wooden stockade type of fencing. This decision necessitated removing existing iron fencing around parts of the Chrysler property and moving vegetative barriers to areas where new construction was not planned. Vermilya-Brown, a New York City construction firm, received a request on 11 July 1942 for an estimate on a 6' 6" high reed fence to enclose the campus, beginning at the southern beach terminus of the Schenck property, around the Academy, down Steamboat Road, and across the entrance to the dock, complete with eleven gates. There was a separate 
task to enclose the drill and athletic field (now called Tombs Memorial Field) with the same type of fencing and four gates. 8

Figure B12. Completed new dock (Mallory Pier), 1942 (USMAA Bland Library).

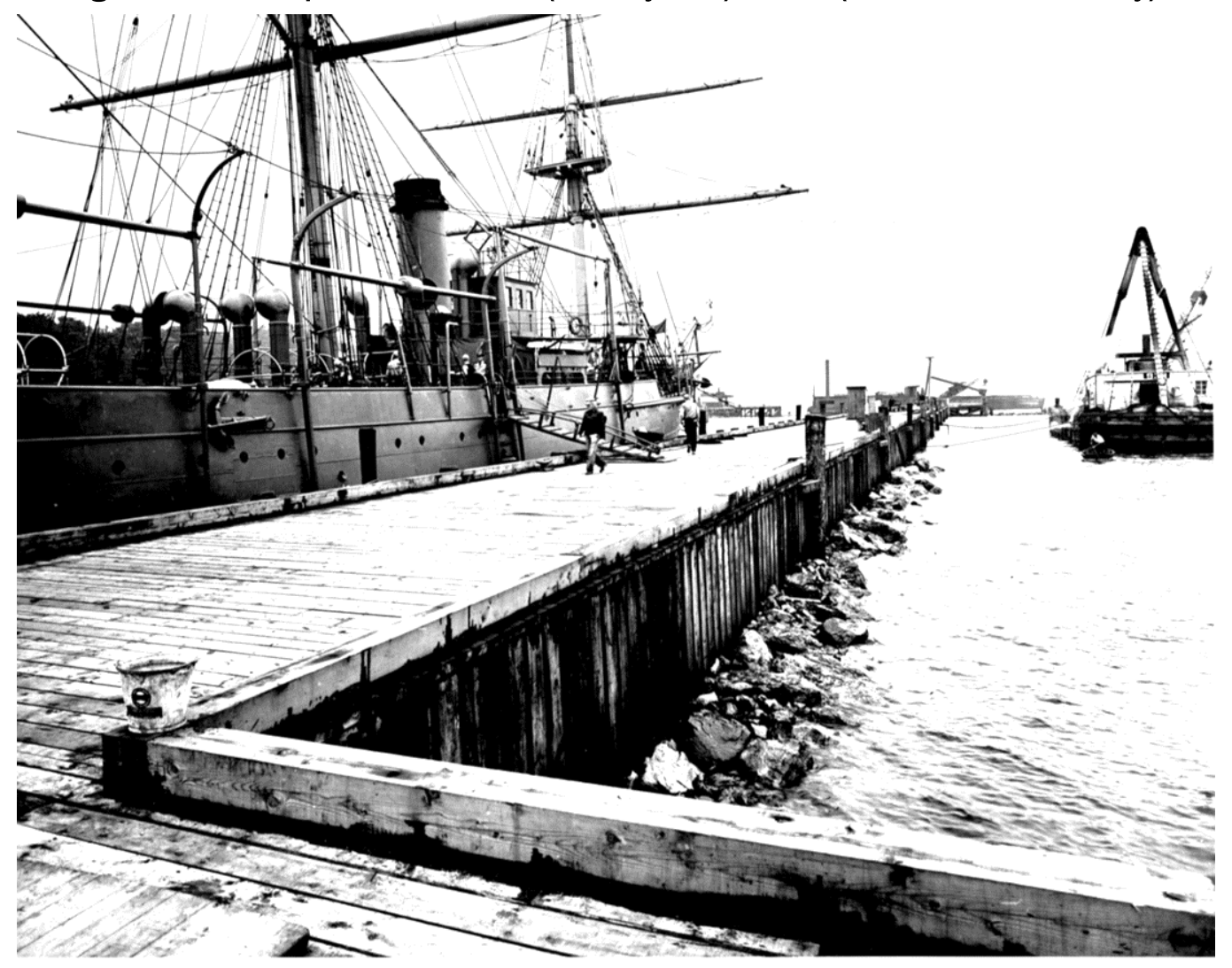

In February 1942, contracts were signed with the architectural and construction firms that would design and build the new Academy. Alfred Hopkins \& Associates of New York City completed detailed plans and specifications for the new buildings, which were designed to accommodate 1,200 midshipmen during peacetime. The firm was selected because they had served as architects for Coast Guard projects at Avery Point and New London, Connecticut, as well as other large-scale government projects including two penitentiaries. Hopkins, however, died in 1941, before the commission for USMMA was received by the firm. The Vermilya-Brown Co. was selected as the construction firm. The company was first contracted to provide temporary CCC buildings for living and working and to construct two cadet quarters buildings, one mess hall and galley, one

8 (NARA, RG 178 Box 23, Correspondence). 
central power plant, utilities, and miscellaneous alterations to the existing buildings, so that the Academy could function.

When Alfred Hopkins \& Associates designed the new buildings, the firm's architects had to work within wartime constraints when determining the building materials. Of the 14 new buildings constructed at the Academy, six were dormitories (Barry, Jones, Cleveland, Rogers, Palmer, and Murphy Halls; e.g., Figure B13), one was a large dining facility (Delano Hall), one was a medical facility (Patten Clinic), one was a drill hall and gymnasium (O'Hara Hall), and five were academic halls or administrative buildings (Bowditch, Fulton, and Samuels Halls, and the Fitch and Furuseth buildings). The six new, three-story barracks (or dormitories) formed two sides of the central quadrangle, of which the Administration Building (Wiley Hall) was the focal point.

Figure B13. Two newly completed dormitories, Barry and Jones Halls, were joined by an arcade, 1943 (USMMA Bland Library).

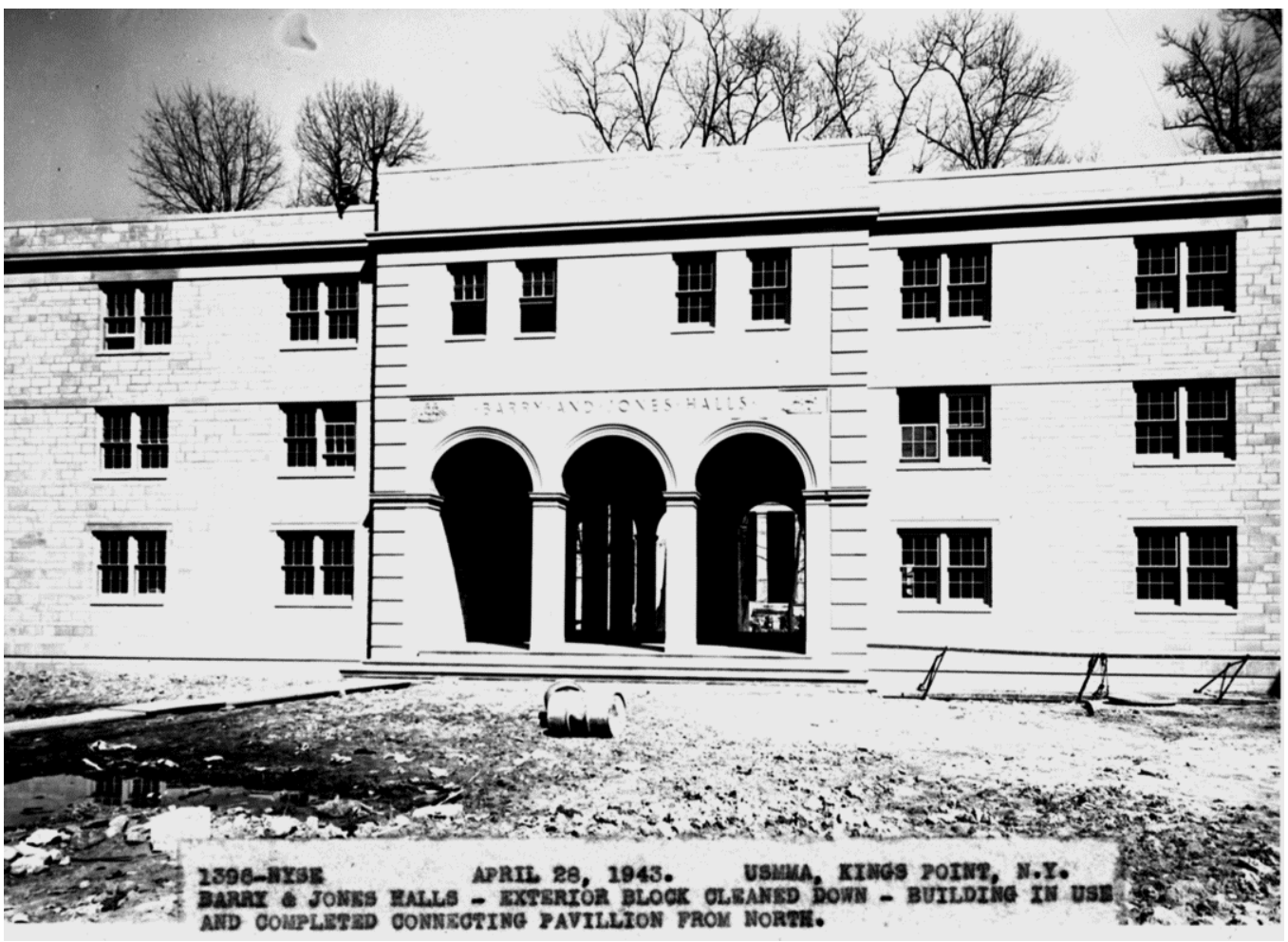

The need for a permanent medical clinic was growing, as were the cadet population and unsanitary conditions. The new Patten Hospital was constructed from 1943 to 1944 , and it was placed between the Neiley house (Quarters A) and garage (Quarters L). Neiley's formal garden 
survived the construction and became a park-like area directly south of the hospital.

The original gate to the USMMA, Marvin Gate, was located at the Third Street (now Marvin Place) entrance off Steamboat Road. In 1943, a new entrance was created at the intersection of Steamboat Road and Steppingstone Lane, which was at the far eastern edge of the USMMA and adjacent to the drill field. In 1946, the new entrance became the main gate to the campus and was designated Vickery Gate. Barney Square (called Formation Square on earlier maps), which is located on the north side of Delano Hall, is an open area that has served as a parade and formation area since 1943 (Figure B14).

Figure B14. Newly completed parade ground (now known as Barney Square), 1943 (USMMA Bland Library).

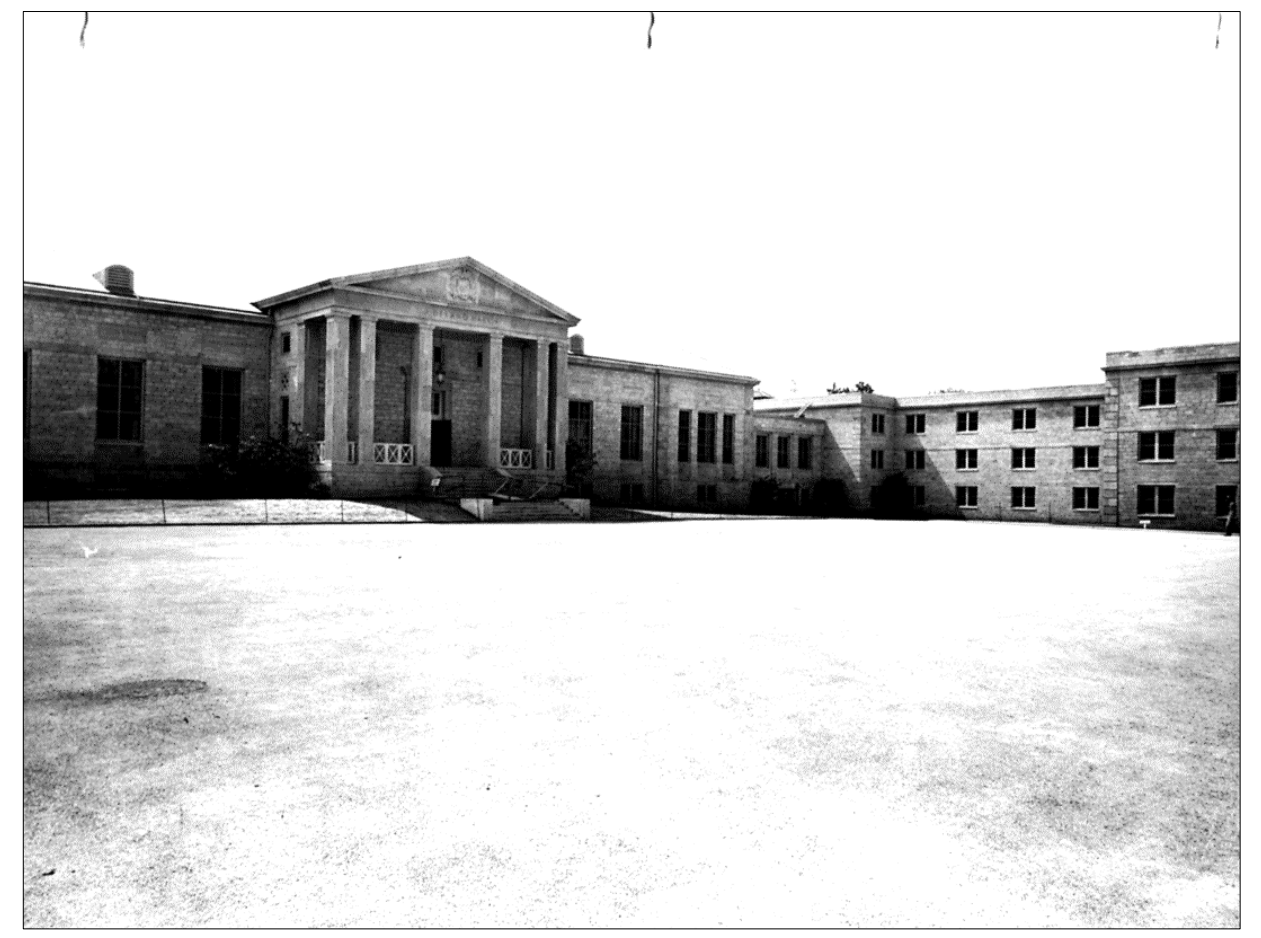

\section{Establishment of the Academy, 1942-present day}

After World War II, the mission of USMMA remained the same as it had been during the war-the Academy existed to educate and train merchant marine officers (Figure B15). The merchant marine training program was once again extended from its condensed 16-month program to a four-year program, one year of which was spent at sea. In 1947, Kings Point became the sole federal maritime school to train future merchant mariners. 
Figure B15. Graduation ceremony at WWII Memorial, 1947 (USMAA Library).

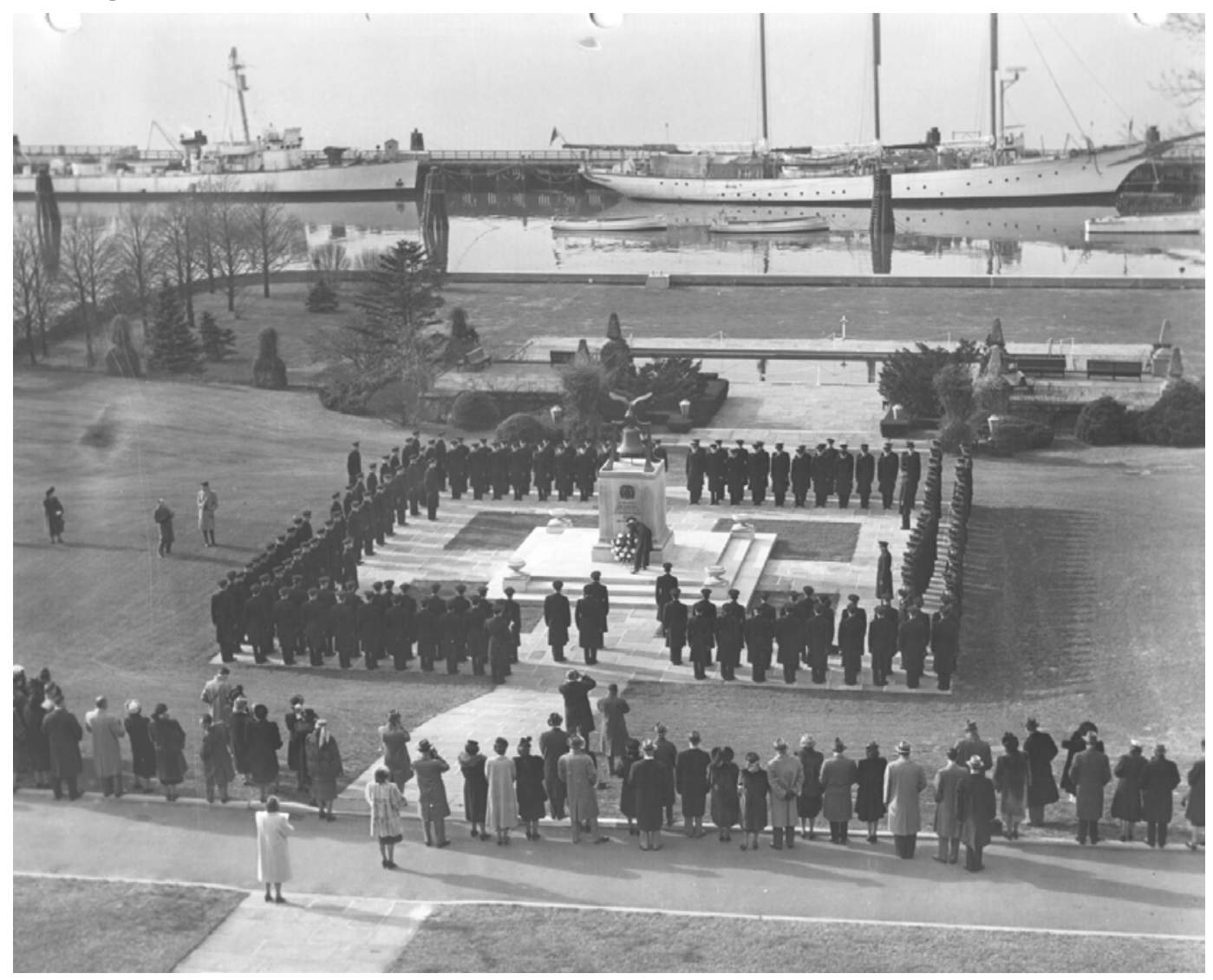

While chapel services had long been held in the music room of the former Chrysler house (Wiley Hall), the Academy plan for new 1945 construction contained a request for a new chapel and provided a sketch showing a gothic revival style structure, but it was not built. In the early 1950s, the Merchant Marine Memorial Chapel Fund was begun to provide for the design and construction of a nonsectarian chapel that was intended to serve as a memorial to merchant seaman who were killed during the World Wars. The chapel was designed by the well-known New York City architectural firm of Eggers \& Higgins and was constructed by the FisherMalik Company of Long Island. Sited northwest of Land Hall and southwest of Wiley Hall, the chapel faces north on a bluff overlooking Long Island Sound. By 1961, the chapel was completed (Figure B16). Donated by the Class of 1954 and erected in 1960, a classical steeple was designed for the chapel. The steeple, known as "Kings Point Light," serves as a navigational beacon. 
Figure B16. Chapel construction in progress, 1960 (USMMA Bland Library).

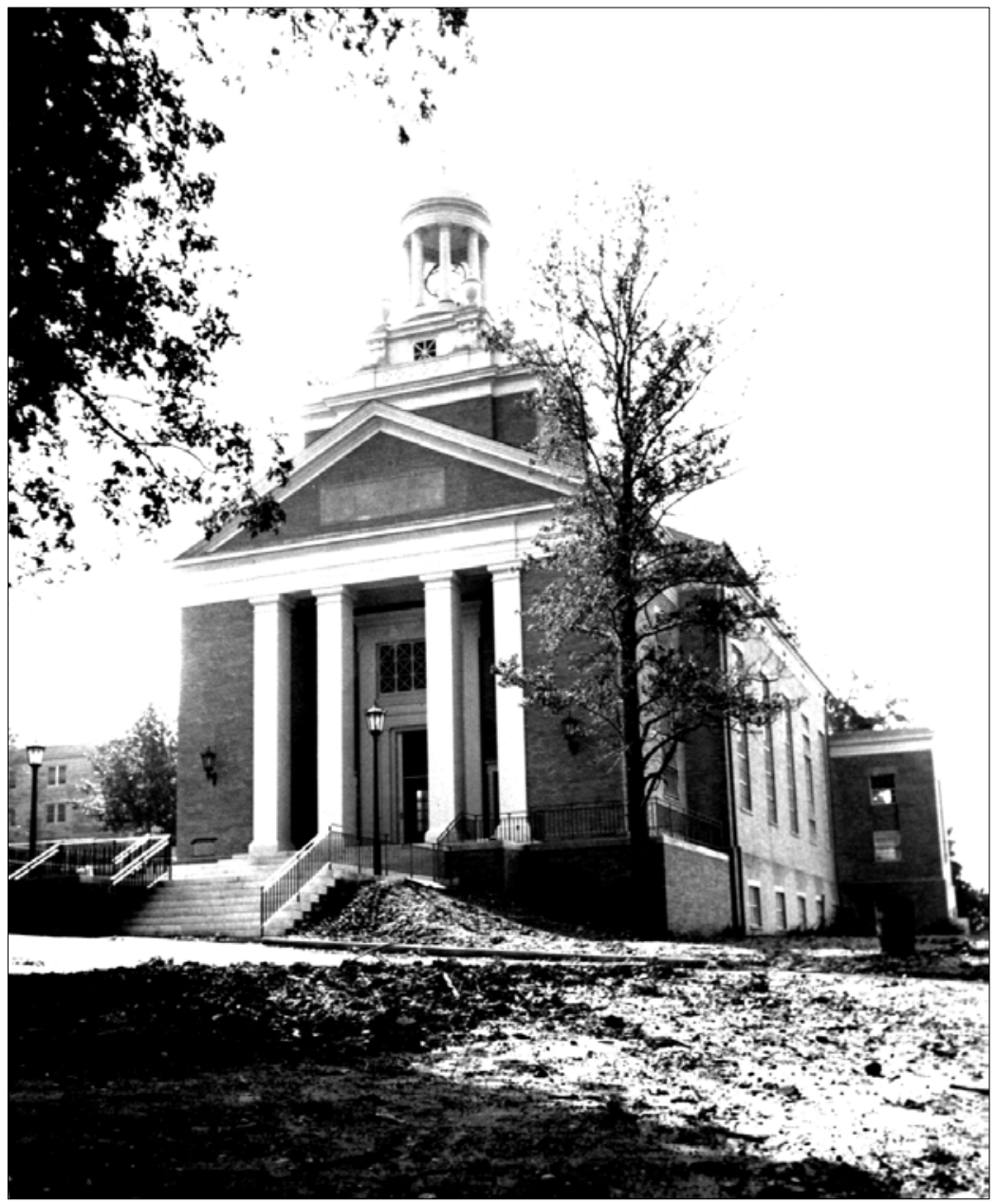

Improvements were also made during the 1960s to the Academy's waterfront facilities, including the construction of three, floating, finger piers along the east side of Mallory Pier and the dredging of Hague Basin. After dredging the basin, about three acres were reclaimed, and construction of a new sea wall was completed.

In 1969, a separate building dedicated for library use was constructed at the north end of the central core of buildings between Fulton and Bowditch halls. The library building, also designed by Eggers \& Higgins, was the culmination of over 25 years of urging by the Board of Visitors for a permanent library. In August 1945, the library was located in Bowditch Hall, where it remained for the next 25 years. The Schuyler Otis Bland Memorial Library was dedicated on 12 December 1968 (Figure B17). The completion of this building formally closed the quadrangle of buildings making up the core of the USMMA campus, finalizing in concrete the 
original design intent for the campus (Figure B18). The campus has largely retained this configuration and appearance to the present.

Figure B17. View of Bland Library, 1968 (USMMA Bland Library).

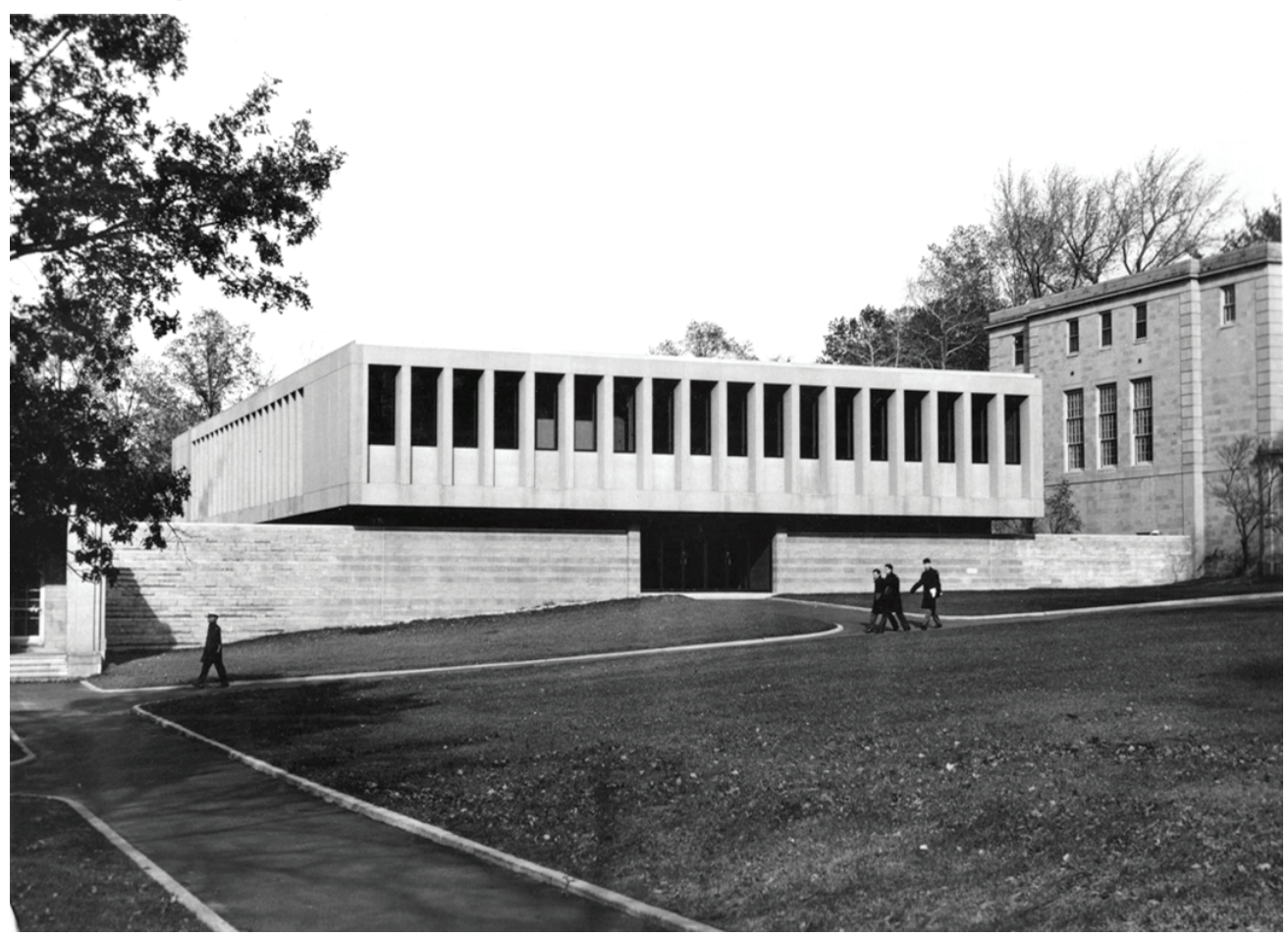

Figure B18. USMMA as it appeared in 1969 (USMMA Bland Library).

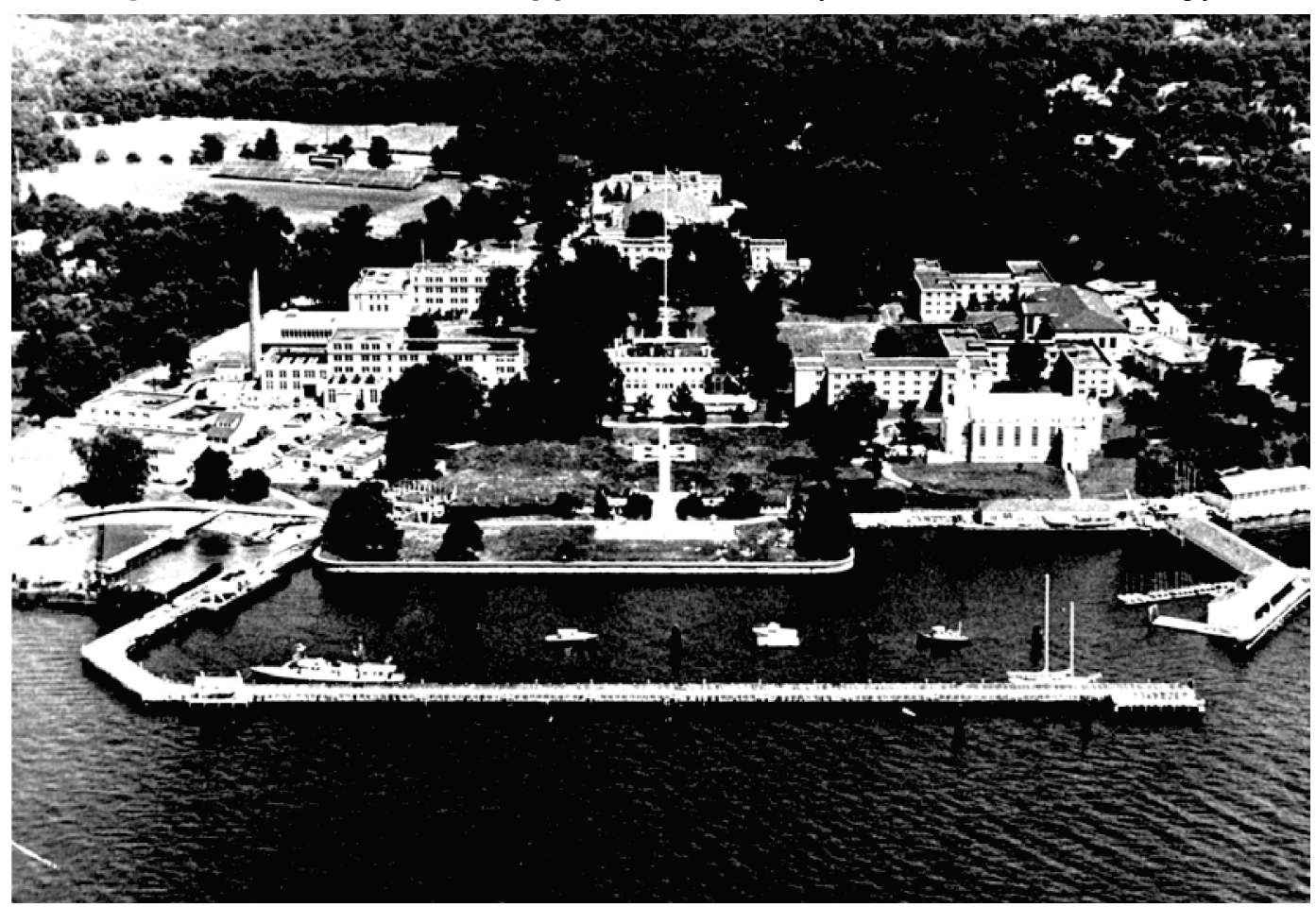


A number of projects were a part of a $\$ 1.8$ million renewal program in 1974-75 to upgrade facilities at USMMA. In 1974, a complex of floating piers was added to the Academy's waterfront, along with a renovation of Mallory Pier and the addition of a 50-ton walking lift for fleet maintenance. At some point after 1969, the bathing beach was filled in to a line that extended farther into the sea than the Chrysler seawall, and the fill made the site eligible for new construction. All 452 midshipman rooms were refurbished with painting, new closets and desks, and carpeting. The athletic field received an all-weather track, classroom buildings were enlarged and modernized, and Samuels Hall received a new wing in 1974. That same year, the Alumni Association raised $\$ 300,000$ to add a large dining and meeting area to Melville Hall.

Through its Kings Point Fund Inc., in 1975 the USMMA Alumni Association purchased the eight-acre Barstow estate on the north side of Steamboat Road, adjacent to the USMMA campus. The park-like estate consisted of the fully furnished 20-room main dwelling on the waterfront, terraced gardens, a four-car garage with apartment above, a guest house, a superintendent's house, a tea house, and a greenhouse. The purchase of the estate, designated as McNulty Campus, ensured that "the last sizeable tract available in the immediate vicinity [of the campus] was secured to allow space for future growth and development of the Academy" (USMMA 1975, 1) The Barstow mansion is now used as the American Merchant Marine Museum and also provides space for special events. The secondary residences on the Barstow estate now house USMMA staff.

A grandstand was constructed at Tombs Field in 1977, and the natatorium was added to O'Hara Hall in 1978. Berger Hall was constructed in 1985 as an administrative facility, as were Buildings A and B of the Department of Facilities Management (western edge of athletic field). In 1988, Fulton Hall received a new wing (Gibbs Hall) for academic use. The Yocum Sailing Center, constructed in 1994 and also funded by alumni, is the most recent addition to USMMA's waterfront facilities. The center provides storage, maintenance, and class space for the Academy's sailing teams and clubs and other waterborne extracurricular activities.

More recent changes to the Academy include interior renovations to all the barracks' buildings, the reconstruction of Barney Square and adjacent landscape in 2013 (Figure B19), and the reconstruction of a portion of Mallory Pier in 2015. 
Figure B19. Changes to Barney Square in front of Delano Hall (ERDC-CERL, 2015).

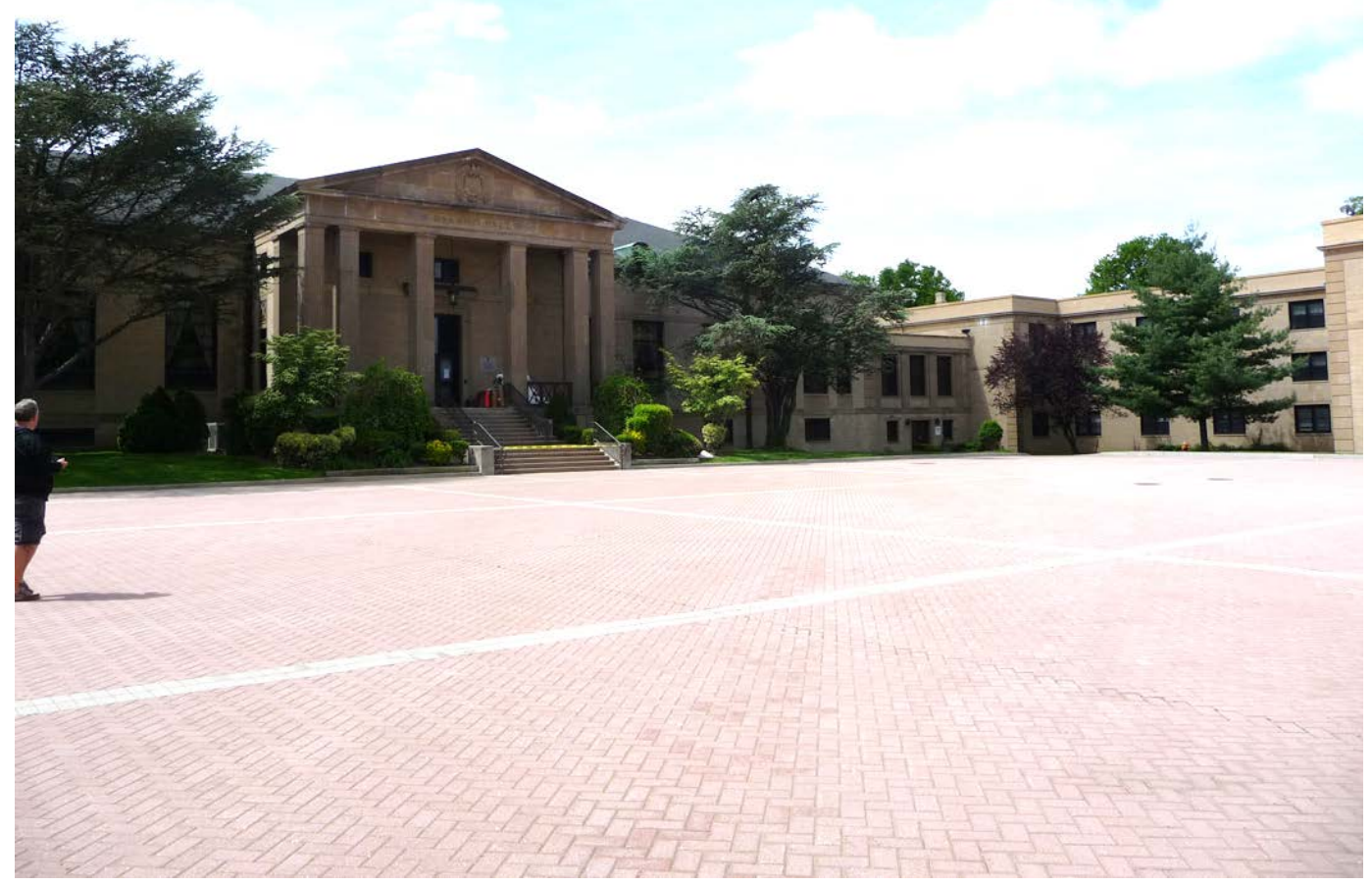




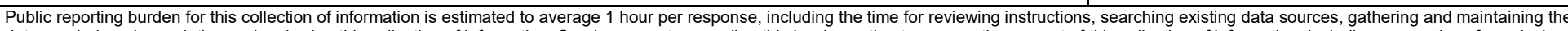

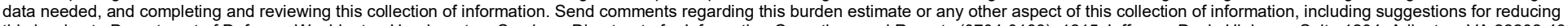

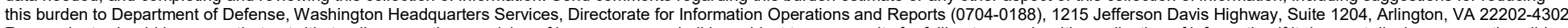

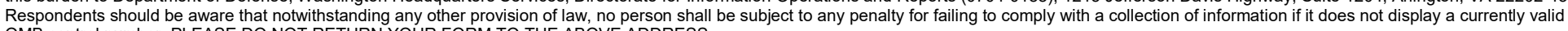
OMB control number. PLEASE DO NOT RETURN YOUR FORM TO THE ABOVE ADDRESS.
1. REPORT DATE (DD-MM-YYYY)
February 2018

\section{REPORT TYPE}
3. DATES COVERED (From - To)

4. TITLE AND SUBTITLE

Landscape Management Plan for the United States Merchant Marine Academy, NY 5a. CONTRACT NUMBER

5b. GRANT NUMBER

5c. PROGRAM ELEMENT NUMBER

5d. PROJECT NUMBER

450153

5e. TASK NUMBER

5f. WORK UNIT NUMBER

8. PERFORMING ORGANIZATION REPORT NUMBER

ERDC/CERL TR-18-2

\section{Construction Engineering Research Laboratory (CERL)}

U.S. Army Engineer Research and Development Center (ERDC)

PO Box 9005

Champaign, IL 61826-9005

\section{SPONSORING / MONITORING AGENCY NAME(S) AND ADDRESS(ES)}

U.S. Department of Transportation, Maritime Administration

MAR-612-W23-495

1200 New Jersey Ave SE

Washington, DC 20590

10. SPONSOR/MONITOR'S ACRONYM(S)

USDOT-MAR

11. SPONSOR/MONITOR'S REPORT NUMBER(S)

\section{DISTRIBUTION / AVAILABILITY STATEMENT}

Approved for public release; distribution is unlimited.

\section{SUPPLEMENTARY NOTES}

\section{ABSTRACT}

The U.S. Merchant Marine Academy (USMMA) is located in Kings Point, New York. The Academy is listed on the National Register of Historic Places (\#14000538). The Historic District contains contributing mansions constructed during the Gold Coast Era and Academy buildings constructed from 1942 to 1969. This report identifies several historic component landscapes within USMMA, and makes recommendations for their maintenance and preservation.

This report establishes landscape guidelines to aid USMMA in preservation of the Historic District. This management plan inventories the existing cultural landscape at the USMMA, and it includes recommendations for managing the historic landscape in the future. The contributing landscapes are identified in the study, and their existing conditions discussed. Treatment recommendations for preserving and rehabilitating the landscapes are provided. This document meets the requirements for federal agencies to address their cultural resources which are defined as any prehistoric or historic district, site, building, structure, or object. Especially relevant is Section 110 of the National Historic Preservation Act, which requires federal agencies to inventory and evaluate their cultural resources.

\section{SUBJECT TERMS}

United States Merchant Marine Academy, Historic preservation, Landscape assessment, Cultural landscapes, Cultural property

\begin{tabular}{|c|c|c|c|c|c|}
\hline \multicolumn{3}{|c|}{ 16. SECURITY CLASSIFICATION OF: } & \multirow{2}{*}{$\begin{array}{l}\text { 17. LIMITATION } \\
\text { OF ABSTRACT } \\
\text { UU }\end{array}$} & \multirow{2}{*}{$\begin{array}{l}\text { 18. NUMBER } \\
\text { OF PAGES } \\
162\end{array}$} & 19a. NAME OF RESPONSIBLE PERSON \\
\hline $\begin{array}{l}\text { a. REPORT } \\
\text { Unclassified }\end{array}$ & $\begin{array}{l}\text { b. ABSTRACT } \\
\text { Unclassified }\end{array}$ & $\begin{array}{l}\text { c. THIS PAGE } \\
\text { Unclassified }\end{array}$ & & & $\begin{array}{l}\text { 19b. TELEPHONE NUMBER } \\
\text { (include area code) }\end{array}$ \\
\hline
\end{tabular}

